\title{
ANÁLISE DO PAPEL DE HORMÔNIOS E FATORES DE CRESCIMENTO NO CONTROLE DA PROLIFERAÇÄO CELULAR EM MAMÍFEROS
}

Tese de Doutoramento apresentada ao Departamento de Bioquímica do Instituto de Química da Universidade de São Paulo. 
Para Salomão e Evelyn Sogayar

Para Hugo A., Ita S. e Hugo S. Armelin 


\section{AGRADECIMENTOS}

$\AA$ Hugo Aguirre Armelin - amigo, companheiro e orientador desta tese.

Aos companheiros de laboratório: Angelo G. Gabarini, Sonia T.S. Funck, Sandra E. Farias, Eico Kimura e Antonio Evaldo, pela colaboração e amızade.

A Sonia T.S. Funck, pela carinhosa ajuda na manu tenção dos camundongos "nude".

A Dra. Lélia Mennucci, pela generosidade com que transmitiu seus conhecimentos na determinação de cAMP.

Ao Dr. Mario Mariano (Faculdade de Medicina Veter $\underline{1}$ nāria da Universidade de são Paulo) pela colaboração na anā lise histopatológica dos tumores.

A Fundação de Amparo à Pesquisa do Estado de são Paulo pelo apoio financeiro. 


\section{INDICE}

\section{ABREVIATURAS}

Pāg .

RESUMO

ix

SUMMARY

xii1

xvi1

I . INTRODUÇÃO

1. Sistemas "in vivo" versus sistemas "in vitro"

2. Estabelecimento de células em cultura

3. Fatores de crescimento para células em cultura

4. Fatores de crescimento e ciclo celular

5. Ciclo celular

6. Análise genética de células de mamíferos em cultura

7. Mutantes regulatörios do crescimento celular

II. MATERIAL E METODOS

1. Iinhagens de células

2. Meios e condições de cultura

3. Manutenção e congelamento de estoques

4. Contagen de células

5. Medidas de incorporação de timidina ${ }^{3} \mathrm{H}$ em DMA

6. Autorradiografia e teste para detecção de micoplasma

7. Medidas de eficiêncla de plaqueamento

8. Clonagen de células

9. Determinação do Indice mitótico

10. Determinação do cariótıpo de uma linhagem de células

11. Ensalo de crescimento en suspensão

12. Estabélecimento de una colónta de camandongos "nude"

13. Ensalo de tumorogenicidade e análise histopatológlca dos tumores

14. Determinação do conteû́o intracelular de CAMP

15. Burificação de fatores de crescimento da pitai tária (PF) 
pág.

16. Tratamento de enzimas, soro e fatores de crescimento com PMSF

17. Protocolo para obtenção de células carencia das para soro ou células em repouso

18. Ensaio para medida da atividade estimulatōria da sintese de DNA

19. Protocolo básico para teste de variantes

20. Protocolo para determinação do tamanho da fase pré-replicativa (Gl)

21. Protocolo para medida da queda de síntese de DNA

22. Hormônios, enzimas, inibidores e outros reagen tes

III. RESULTADOS

1. Atividade estimulatóría da sintese de DNA por soro e fatores de crescimento

1.1. Atividade de soro

1.2. Atividades de EFG e PF

1.3. Resposta de células carencladas

2. Anál1se do comportamento de células $3 T_{3}$

2.1. Parâmetros de crescimento

2.2. Efeito de soro, hormônios e fatores de crescimento

2.3. Efeito da densidade da população sobre a resposta celular à reestimulação da sinte se de DNA

2.4. Cinética da entrada de células em $S$ após estimulação

2.5. Efeitos da diminuição da concentração de soro no melo de cultura

3. Análise do comportamento do mutante STI deriva do de células $3 T 3$

3.1. Isolamento da Iinhagem ST1

3.2. Parâmetros de crescimento

3.3. Efeito de hidrocortisona

3.4. Anālise da atividade de diversos esteröides sobre células STl 


$$
\text { vii }
$$

3.5. Ação de hidrocortisona no ciclo celular Pág.

3.6. Efeito de hidrocortisona sobre a reesti mulação de células STl carenciadas para soro

3.7. Ação de fatores de crescimento sobre cé lulas STl

3.8. Ação de hidrocortisona sobre tumores in duzidos por células STI

3.9. Níveis intracelulares de cAMP em células STI

3.10.Alterações morfolōgicas de cêlulas STl: efeito de soro, cAMP e hidrocortisona

4. Análise do comportamento de células adrenais Y-1

4.1. Efelto de soro

4.2. Efeito de hormônios e fatores de crescí mento

4.3. Efeito de ACTH e cAMP

4.4. Cinētica da reestimulação de sintese de DNA

4.5. Ação de ACTH no ciclo celular

5. Análise do comportamento do variante AR-1 der 1 vado de células adrenais $\mathrm{Y}-1$ e resistente a ACTH

5.1. Isolamento da linhagem AR-1

5.2. Efeito de soro, hormônios e fatores de crescimento

5.3. Efeito de CAMP

IV. DISCUSSÃO

1. Células normals e cêlulas transformadas

2. Natureza dos fatores de crescimento

3. Fatores de crescimento é ciclo celular

4. Efeito de hidrocortisona no mutante STI

5. Efeito de ACTH em células adrenais

V. REFERENCIAS BIBLIOGRAFICAS 

ABREVIATURAS

ACTH : adrenocorticotropina

Ara C : citosina arabinosídeo

ATP : trifosfato de adenosina

BAPNA : $\alpha-\mathrm{N}$-benzol1-DL-arginina-p-nitroanilida HCl

BSA : albumina de soro bovino

BUdR : bromodesoxiuridina

CAMP : $3^{\prime}, 5^{\prime}$-monofosfato cíclico de adenosina

5'-AMP : 5'-monofosfato de adenosina

CGMP : 3',5'-monofosfato cíclico de guanosina

Ci : Curie $\left(2,2 \times 10^{12} \mathrm{dpm}\right)$

cpm : contagens por minuto; medida de radiatividade

CS : "calf serum" (soro de vitelo)

DME : "Dulbecco's modified Eagle's Minimal Medium"

DNA : ácido desoxirribonucleico

EDTA : ācido etilenodiaminotetraacētico

EGF : "epidermal growth factor"

FCS : "fetal calf serum" (soro feral bovino)

FGF : "fibroblast growth factor"

FSH : hormônio estimulador do folfculo

FUdR : fluordesoxiuridina

GH : hormônio de crescimento

GMP : monofosfato de guanosina

IMP : monofosfato de Inosina

LH : hormônio luteinizante

MSA : "multiplication stimulating activity"

NGF : "nerve growth factor" 

NSILA : "non suppressible insulin-like activity"

OGF : "Ovarian growth factor"

PBS : solução salina fosfato $\mathrm{pH} 7,0$

PBSA : solução salina fosfato $\mathrm{pH} 7,0$ sem $\mathrm{Ca}^{2+}{\mathrm{e} \mathrm{Mg}^{2+}}^{2+}$

$\mathrm{PF}$ : fator de crescimento extraído de pituitāria

PGF $_{2 \alpha}$ : Prostaglandina $F_{2 \alpha}$

PMSF : fluoreto de fenilmetilsulfonila

POPOP : 1,4-bis-2-(5-feniloxazol11)-benzeno

PPO : 2,5-difeniloxazol

RNA : ācido ribonucleico

TCA : ācido tricloroacētico

Timidina ${ }^{3} \mathrm{H}$ : timidina tritiada

TSH : hormônio estimulador da tireóide 



\section{RESUMO}

o objetivo deste trabalho fol estudar o processo pelo qual hormônios e fatores de crescimento controlam a proliferam ção celular em mamíferos. O modelo experimental utilizado foi Iinhagens de cểlulas estabelecidas em cultura. Os estudos cen traram-se em dols tipos básicos de células: fibroblastos e células adrenais e o ataque experimental foi feito sob dois pontos de vista: bioquímico e genético.

o ataque bioquímico envolveu desenvolver estudos cinê tícos da sintese de DNA não só durante o carenclamento de cêlú las para soro, como tambēm durante a reestimulação de células carenciadas por:soro, hormôntos e fatores de crescimen to. Medidas do conteúdo intracelular de CAMP foram efetua das com o intuito de adquirir informações à respetto do meca nismo de ação destes fatores.

Um modelo de ciclo celular fol proposto no qual o con trole do cresclmeito serla exercido atravês de reguladores positivos e negativos que agiriam estimulando ou inibindo a passagem de cêlulas do estado de repouso (Go) para a fase prolife rativa. Entre os reguladores positivos (estimuladores) do sis tema fibroblasto, encontra-se hormônios classicos, como este rôldes e Insulina, e fatores de crescimento de natureza hormo nal como EGF, PF (fator protelco extraido de glandulas pituita rias) e prostaglandina $\mathrm{F}_{2 \alpha}$. O esterólde hldrocortisona pode agir como regulador negativo, Inibindo o orescimento de fibro blastos. 
Medidas do período de tempo transcorrido desde a estimulação de células carenciadas (Go), até o aparecimento da onda de síntese de DNA (período definido operacionalmente como Gl) foram feitas. Em fibroblastos $3 T 3$ este periodo fol de 12 a 13 horas tanto para células estimuladas com soro como com hormônios clássicos (hidrocortisona, insulina) ou fatores de crescimento (EGF, PF) ou ainda com combinações deles $(\mathrm{EGF}+\mathrm{PF}+$ insulina; $\mathrm{PF}+$ hidrocortisona; $\mathrm{PF}+$ hidrocortiso na + insulina). No sistema células adrenais, adrenocorttco tropina (ACTH) foi o único hormōnio clässico que apresentou atividade sobre o crescimento destas células e também o único efetuador negativo encontrado. Neste sistema PF mostrou-se como o único fator com atividade estimulatōria sobre o cresc1 mento. Gl aqui fol de 11 horas tanto para células estimula das com soro como com PF. Além disso os hormônios clássicos hidrocortisona e insulina não apresentaram atividade esti mulatōria por si só ou em combinação com PF.

A anālise da ação de hidrocortisona no sistema fibroblasto:e de ACTH no sistema células adrenais estimuladas, forneceu evidências de que após deixar Go, em direção a s, nu彑 ma certa altura de $\mathrm{Gl}$ as células tornam-se irreversivelmente comprometidas com o processo replicativo. Este comprometimen to parece ocorrer 5 horas antes de $\mathrm{S}$, sendo referido como $\mathrm{Gl}^{\mathrm{C}}$.

Em face destes resultados foi proposto que os regula dores agem estimulando ou inibindo a transição Go $\rightarrow \mathrm{Gl}^{\mathrm{C}}$.

Na tentativa de obter maior definição do sistema de controle do crescimento, aproveitamo-nos das vantagens oferecidas pelo modelo experimental usado, para a busca. de 
mutantes do tipo regulatório. Esta busca resultou no isolamento das linhagens STl e AR-l, derivadas, respectivamente,de fibroblastos $3 \mathrm{~T} 3$ e células adrenais $\mathrm{Y}-1$.

Entre os vários aspectos interessantes da linhagem STl destaca-se: a) o dramātico efeito de hidrocortisona causando mudança nas características das células as quais passam de um fenōtıpo tipicamente transformado para normal. Este fenômeno foi observado tanto "in vitro" (atravēs de medidas de parâmetros de crescimento) como "in vivo" (atravês de ensaios de tumorogenicidade); b) as alterações morfológi cas de caráter antagônico provocadas, por um lado, pela adição de hidrocortisona (causando achatamento) e, por outro,pe la retirada do soro ou adição de cAMP ao meio de cultura (arredondamento) . Atravēs do estudo da ação de inibidores, obteve-se evidências do envolvimento de microtúbulos nestas alterações morfológicas.

A anālise do conteúdo intracelular de cAMP indicou que este nucleotídeo não atua como mediador da ação de hidro cortisona. Sua ação parece ser devida à indução de altera ções no sistema superficie celular - membrana -citoesqueleto. Ao contrário de outros variantes de células Y-l resistentes à ACTH, cēlulas AR-l mostraram-se também resisten tes a cAMP. A utilidade destas células nos estudos da postu lada mediação deste nucleotídeo na ação de ACTH, é óbvia. 

xvii

SUMMARY

The aim of this work was to study the process by which hormones and growth factors control proliferation of mammalian cells. Cell lines established in culture were used as the experimental model. The studies were centered on two basic types of cells: fibroblasts and adrenal cells and the experimental approach was made from two viewpoints: biochemical and genetic.

The biochemical approach involved kinetic studies of the DNA synthesis process not only during serum starvation but also during restimulation of serum starved cells by serum, hormones and growth factors. Intracellular cyclic AMP determinations were made in order to gain informations on the mechanism of action of these factors.

A cell cycle model was proposed in which cell growth control would be exerted by positive and negative regulators that would act by stimulating or inhibiting the flow of cells from a resting state (Go) to the proliferative phase. Among the positive regulators (stimulators) found for the fibroblast system are: classical hormones, like sterolds and insulin, and growth factors of homonal nature, like EGF, PF (protein factor extracted from pituitary glands) and prostaglandin $F_{2 \alpha}$. The sterold hydrocortisone can also act as a negative regulator, inhibiting fibroblast growth.

Measurements of the time interval between stimulation of serum starved (Go) cells and the onset of DNA synthesis (period that is operationally defined as Gl) were made. In 3T3 
fibroblasts this period was 12 to 13 hours for cells stimulated not only by serum but also by classical hormones (hydrocortisone, insulin) or growth factors (EGF, PF) or even by combinations of these factors (EGF + PF + insulin; PF + hydrocortisone; $\mathrm{PF}+$ hydrocortisone + insulin). In the adrenal system, adrenocorticotropin (ACTH) was the only classical hormone to present activity on the growth of these cells and also the only negative regulator found. In this system PF was shown to be the only factor with growth stimulatory activity. Gl was estimated as 11 hours for cells stimulated with serum or PF. Moreover hidrocortisone and insulin had no stimulatory activity "per si" or in combination with PF.

The analysis of hydrocortisone action on the fibroblast system on one hand and of that of ACTH on the adrenal system, on the other, indicated that upon leaving Go, towards $\mathbf{s}$, at a certain point in $\mathrm{Gl}$, cells become irreversibly committed to the replicative process. This commitment seems to occur 5 hours before $\mathrm{S}$ and is referred to as $\mathrm{Gl}^{\mathrm{C}}$.

In view of these data we proposed that regulators act by stimulating or inhibiting the transition $\mathrm{Go} \rightarrow \mathrm{Gl}^{\mathrm{C}}$.

In an attempt to obtain a better definition of the growth control system and taking advantage of the experimental model utilized, we searched for mutants of the regulatory type. This search resulted in the isolation of the lines STI and AR-1 from 3T3 fibroblasts and $Y-1$ adrenal cells, respectively. Among several interesting aspects of the STI cell line, we point out: a) the dramatic effect of hydrocortisone changing the characteristics of these cells from a typically transformed phenotype to a normal pattern. This phenomenon 
was observed both "in vitro" (by measuring a number of growth parameters) and "in vivo" (by tumorogenicity assays). b) morphological alterations of antagonistic nature caused by hydrocortisone (flattening) on one hand, and by the removal of serum or CAMP addition to the culture medium (rounding) on the other. Evidence for the involvement of microtubules in these alterations were obtained through studies on the action of several inhibitors.

Quantitative analysis of intracellular cAMP indicated that this nucleotide does not act as a mediator of hydrocortisone action. Rather, this action seems to be due to the induction of alterations on the cell surface-membrane-cytoskeleton system.

Contrary to other variants of the $\mathrm{Y}-1$ line which are resistant to ACTH, AR-1 cells are also resistant to CAMP. The usefulness of these cells in studies of the postulated mediation by CAMP of the ACTH action, is obvious. 


\section{INTRODUÇÃO}

\section{SISTEMAS "IN VIVO" VERSUS SISTEMAS "IN VITRO"}

Num individuo adulto, enquanto algung tecidos estão em continua proliferação (como as células epiteliais da cripta do intestino delgado) outros são incapazes de se dividir (como os neurônios do tecido nervoso) e outros ainda possuem células que raramente se dividem mas que podem ser estimuladas a fazê-lo apôs estimulos apropriados (como o fígado após hepatectomia parcial). Além disso o crescimento de um animal constitui-se em processo altamente ordenado e regulado, onde a integração dos diversos sistemas e o delicado balanço homeostātico são atingi dos graças ao sistema endōcrino.

A endocrinologia clássica estabeleceu o concetto de que a proliferação celular em mamifferos é controlada por regula dores endōcrinos ou hormonais tröpicos (gonadotropinas, estrógeno, etc). A metodologia empregada envolvia: a) demonstração de que um dado örgão tem papel endôcrino na economła do organis mo. Isto era felto atravês da crlação de uma deficiência (por ablação clrūrgica ou química) e superação da deficiência (por administração de extratos crûs ou transplantes de örgãos; b) dẹ terminação da natureza química do material ativo. Uma vez disponto de ensalo para medida da atividade, partir para o isolamento, purificação, identiflcação e eventualmente sintese da es pēcie ativa; c) determinação dos mecanismos de biossintese e se creção do hormônio; d) determinação do mecanismo de ação do 
hormônio (tecido alvo; número e tipos de efeitos ao nível celu lar e molecular).

Entretanto os estudos feitos "in vivo" apresentam uma série de dificuldades práticas as quais limitaram muito o progresso nas investigações sobre os fatores que afetam o cresci mento celular assim como seus mecanismos de ação. Multas destas dificuldades podertam ser superadas se fosse possivel 1solar e manter as cêlulas-alvo em cultura. Infelizmente atē o momento não se dispõe de um mêtodo definido para o establec1 mento de células-alvo para os hormônios tróplcos em cultura.Po rém já se pode contar com uma sêrie de linhagens de células que apresentam, em cultura, respostas de crescimento que, no minimo, mimetizam algumas respostas fisiológlcas encontradas "in vivo". A importância dos mētodos de cultura de células pa ra a elucidação de uma sērie de problemas bāsicos da endocrino logia pode ser ilustrada com a descoberta do mecanismo de ação de GH (hormônto de crescimento) via fator de sulfatação ou somatomedina (SALMON \& DAUGHADAY, 1957; HALL \& VAN WYCK, 1974; UTHNE, 1973) e a descoberta e 1solamento dos fatores liberado res hipotalâmicos (BURGUS et al., 1969). Além disso a disponibilidade de cêlulas isoladas e com tempo de geração relativa mente curto abriu perspectivas do emprego, em mamíferos, da me todologia anteriormente desenvolvida pela genëtica de microrga nismos.

o trabalho aqui descrito teve como objetivos gerais usar células em cultura para estudar os fatores ambientais que desencadelam proliferação celular (hormônios clāssicos, fato res de crescimento extraidos de pituitária e sorol e seus 
mecanismos de ação, procurando associar ao enfoque bioquímico - enfoque genético com a busca de mutantes do tipo regulató rio para cêlulas somátıcas.

A fim de melhor situar o problema uma breve anālise da literatura será felta.

2. ESTABELECTMENTO DE CELULAS EM CULTURA

Praticamente qualquer tipo de cêlula pode ser coloca da em cultura após submeter o tecido a tratamento mecânico ou enzimātico (tripsina, colagenase, etc) adequados, passando es ta a constituir uma cultura primäria. Estas culturas, no entanto, são de valor limitado devido a: 18) terem curta duração podendo ser subcultıvadas um número restrito de vezes; 28) perderet rapidamente as caracteristicas do tecido de ori gem. Este fenômeno, inicialmente aceito como desdiferencia ção, colocou sérios entraves na utilização de células em cụltura como modelo experimental. Coube a sATo et al. (1960)mos trar que a "desdiferenciação" nada mais era que a multiplica ção seletiva de cëlulas oriundas de tecido conectivo (fịbro blastos) as quais passam, assim, a constituir maioria na popu lação. O isolamento de cêlulas funcionais em cultura dependia do emprego de têcnicas de seleção adequadas.

Usando a técnica de passagem alternada anlmal-cultura (BUONASSISSI et al., 1962) de tumores funcionais, um grande número de linhagens diferencladas estãveis foram desenvolvidas: cēlulas de pituitāria que secretam ACTH (BUONASSISSI et al., 1962); cêlulas adrenals que respondem a ACTH(YASUMURA et al., 1966); células de glia (BENDA et al., 1968), células 
pituitárias que secretam GH e prolactina (YASUMURA et al.,1966; TASHJIAN et al., 1968); cêlulas de neuroblastoma (AUGUSTI-TOCCO \& SATO, 1969). Aqui deve ser também destacado o trabalho de TODARO \& GREEN (1963), os quais, por um processo sistemático, estabeleceram em cultura diversas linhagens de fibroblastos de embrião de camundongo, das quais a mais importante è a linhagem 3T3. Esta linhagem estabelecida tem, em cultura, um compor tamento que lembra aquele de culturas primârlas de cêlulas normais: ao atingir confluêncla param de crescer mantendo-se, porém, viáveis por longos períodos de tempo. Este fenômeno, conhecido por inibição de cresclmento por contacto ou inıḅıção de contacto, fol tomado como o reflexo, em cultura, dos mecanismos de controle de crescimento que operam no animal (AARONSON \& TODARO, 1968). Devido a isto as células 3T3 passaram a ser usa das em muitos laboratórios como um protôtipo de células normais.

Células da linhagem $3 \mathrm{~T} 3$ assim como outras linhagens em cultura requerem a presença de soro no melo de cultura. TODARO et al. (1965) e HOLLEY \& KIERNAN (1968) mostraram que o cresci mento de fibroblastos $3 \mathrm{~T} 3$ ê diretamente controlado por fatores do soro. O papel do soro no meio de cultura è fornecer substâncias reguladoras do crescimento celular - hormônios do tipo clássico ou fatores de crescimento do tipo hormonal (ARMELIN, 1975). A existência de algumas linhagens que crescem em meio quimicamente definido na ausêncla de soro è devida ao fato de serem capazes de sintetizar em cultura fatores de crescimento (DULAK \& TEMIN, 1973) ou terem sido selecionadas para crescer na ausência de reguladores. 
3. FATORES DE CRESCIMENTO PARA CELULAS EM CULTURA

Grande quantidade de esforços tem sido empregado na tentativa de definir os fatores do soro que são essenciais para o crescimento das cêlulas. Essencialmente três tipos de en foque foram usados: a) tratamento do soro para extração seletí va de hormônios e fatores de crescimento (ARMELIN, 1973; NISHI KAWA et al., 1975); b) emprego de soro extraido de animais ope rados (hipofisectomizados, adrenalectomizados, tireoidectomiza dos, ovarectomizados, etc) e, portanto, deficiente em certos tipos de hormônios (SAMUELs et al., 1974); c) fracionamento do soro para purificação e isolamento dos fatores reguladores de crescimento (JAINCHILL \& TODARO, 1970; PAUL et al.,1971;LIPTON et al., 1971). O grande número e quantidade de proteínas presentes no soro contrastando com as baixissimas concentrações de fatores de cresclmento tornaram a tarefa de purificação e isolamento destes fatores à partir de soro extremamente dificil (HOLLEY \& KIERNAN, 1971).

o estudo de fatores de crescimento tomou novo impalso quando, investigando as exlgênclas de células 3T3 para crescimento, fol verificado (ARMEIN, 1973) que extratos de pitultārla continham atividade promotora de cresclmento para estas cêlulas. Neste mesmo trabalho foram apresentadas evidências de que a atividade era devida a um fator de natureza protelca o qual era diferente dos hormônıos conheeldos da hipôfise e potenclalmente fäcll de purtelcar. Devido ao fato de cêlulas 313 serem altamente dependentes de soro, culturas mantidas em baixa concentração (ou na total ausêncla) de soro param de se d1vidir e entram num estado de repouso. A reestimulação destas 
células consistia num ensaio extremamente eficiente de substân cias reguladoras extracelulares que promovem iniciação de cres cimento. O desenvolvimento deste trabalho teve como consequên cias o surgimento da possibilidade de obtenção de fator de cres cimento puro e de usá-lo como instrumento na investigação de mecanismos de controle de crescimento e ainda de usar a glându la pituitária como fonte de outros fatores de crescimento ainda desconhecidos.

Uma vez dispondo de um ensaio adequado e de evidências para uma fonte potencial da atividade, um fator de cresci mento de pituitāria foi purificado atē homogeneidade por GOSPODAROWICZ (1974) e designado FGF ("fibroblast growth factor"). A partir de hipófise bovina ARMELIN et al. $(1976,1977)$ têm obtido uma preparação designada PF ("pituitary factors")a qual contēm umas poucas proteínas e possui atividade estimuladora do crescimento de diversos tipos de células.

Outros fatores regulatórios do crescimento de fibroblastos 3T3 foram descobertos. Verificou-se por exemploLARMEIN, 1973) que os hormônios clássicos hidrocortisona e insulina tinham efeito sinergistico sobre a atividade do fator de pituită ria e alnda que o fator de cresclmento epitelial (EGF) isolado e purificado por COHEN (1962) apresentava atividade estimulatō ria para cêlulas 3T3. No entanto, a combinação de fator de pituitária, hidrocortisona e insulina embora extremamente eficiente na estimulação da inlclação de crescimento revelou-se insuficiente para terminação da divisão celular (ARMELIN \& ARMELIN, 1975). Estes dados sugeriam que o soro devia fornecer outros reguladores os quais seriam essenciais para propi ciar crescimento e sobrevivência das cêlulas. 
Além daqueles acima citados, vārios outros polipeptídeos com atividade de fator de crescimento para células em cul tura foram isolados (de fontes diversas tais como soro, plasma, sobrenadante de células em cultura, glândula salivar,etc) entre os quais: OGF ou "ovarian growth factor" (GOSPODAROWICz et a1., 1974), NGF ou "nerve growth factor" (LEVI-MONTALCINI \& ANGELETTI, 1968), MSA ou "multiplication stimulating activity" (DULAK \& TEMIN, 1973), somatomedinas ou fatores de sulfatação e de timidina (VAN WICK et al., 1971; HALI \& UTHNE, 1971),NSILA ou "non suppressible insulin like activity" (RINDERKNECHT \& HUMBEL, 1976 ) e ainda um fator de plaquetas (Ross et al., 1974) o qual parece ser.o mesmo purificado por ANTONIADES \& STATHAKOS, 1975. Alguns destes polipeptideos (como MSA, NSILA, somatomedina C e possivelmente também somatomedinas A e B) guardam estreita relação com insulina, competindo pelo receptor especifico de insulina e apresentando analogias de sequência mas podem ser distinguidos de insulina por reação com anticorpos de alta af $\underline{\underline{1}}$ nidade por insulina.

Outras substâncias têm sido implicadas como reguladores do crescimento de fibroblastos. Alguns autores sugeri ram que tratamentos breves de flbroblastos em repouso com trip sina e outras proteases desencadeavam o processo de divisão celular (BURGER, 1971, 1973, SEFTON \& RUBIN, 1970, BURGER et a1., 1972; SCHNEBLI \& BURGER, 1972; NOONAN \& BURGER, 1973,CHEN \& BUCHANAN, 1975). Estes resultados, entretanto não puderam ser confirmados por outros laboratôrios (GLYNN et al., 1973; HOLLEY \& KIERNAN, 1974; ARMEIIN et al., 1976, nesta tese). Assim,a declsão de colocar proteases entre os fatores reguladores 
da proliferação celular em fibroblastos deve aguardar um ataque mais sistemātico e a anālise comparativa dos diversos sistemas empregados.

Tem sido mostrado que glicocorticóides (THRASH CUNNINGHAM, 1973; ARMELIN, 1973) e prostaglandina $F_{2 \alpha}$ (ASUA et al., 1977) agem como estimuladores da proliferação celular no sistema fibroblasto 3T3. Papel semelhante tem ainda sido atribuído a substâncias de baixo peso molecular como nutrientes (HOLLEY \& KIERNAN, 1974) e nucleotideos cíclicos (SEIFERT \& RUDLAND， 1974).

\section{FATORES DE CRESCIMENTO E CICLO CELULAR}

Apesar da lista de reguladores para o sistema 3T3 ter se estendido consideravelmente nos ültimos anos, completa substituição do soro por combinações de hormônios e fatores de cres cimento constitui-se em meta ainda não alcançada (algum sucesso neste sentido foi relatado recentemente por HAYASHI \& SATO, 1976 ,para algumas linhagens de células). Entretanto a disponibllidade de fatores puros permitia agora o ataque ao problema do mecanismo pelo qual estas substânclas desencadeavam o proces so proliferativo. As questões que pareciam mals fundamentais eram: o que acontece ao ciclo de vida de uma cêlula quando esta é colocada em condições de carêncla de soro? De que maneira os diversos efetuadores interferem com este ciclo? E importante notar que durante multo tempo os investigadores preocupados com fatores de crescimento estiveram dissociados daqueles volta dos para a elucidação dos vãrtos eventos que ocorrem no ciclo 
de vida de uma célula. Vejamos agora o "status" de conhecimen to no campo de ciclo celular.

\section{CICLO CELULAR}

Embora duas fases distintas - mitose e interfase - tẹ nham sido reconhecidas desde muito tempo, a divisão do ciclo celular em 4 fases só surgiu can o trabalho clássico de HOWARD \& PELC (1953). Estes autores propuseram as designaçōes Gl (para o periodo que antecede a replicação de DNA); s (para a fase de sintese de DNA); G2 (para a etapa que sucede a replica Ção de DNA e precede a divisão celular) e M (para o período de divisão celular). Vârios mêtodos para medidas da duração das diversas fases do ciclo celular foram desenvolvidos, dos quais - mais importante e o de maior alcance é a anãlise da fração de mitoses marcadas de QUASTLER \& SHERMAN (1959). Este tipo de anālise revelou que a maior parte das diferenças observadas para o tempo de geração entre os diversos sistemas podia ser atribuIda à variabilidade do periodo prē-sintētico (GI) uma vez que S, G2 e M apresentavam variações muito restritas. Duraçōes de Gl de meses e até anos eram encontrados para sistẹ mas que proliferam lentamente. Alêm disso variações de Gl eram encontradas mesmo dentro de populações homogêneas.

A anâlıse cinētıca do sistema flgado em regenera ção (apôs hepatectomia parcial) levou LAJTHA (1963) a introdu zir o termo Go para descrever cêlulas em repouso ou, por assim dizer, fora do clclo celular, mas que são capazes de entrar normalmente no ciclo mediante estimulo apropriado (hepatectomia) . 
Este conceito foi incorporado no modelo de ciclo celú lar proposto por TEMIN (1971) esquematizado na fig. 1 , onde S, G2 e M tềm seus significados usuais porém Gl è visualizado como: a) fazendo parte do ciclo mitōtico (circulo de fora) sendo aqui representado por uma fase logo apōs a mitose (MGI) e outra antecedendo $s$ e correspondendo a células estimuladas a dividir (SGI); b) uma parte fora do ciclo mitótico (circulo Interno) ou na Interfase (IGI) e que corresponderia a Go. Nes

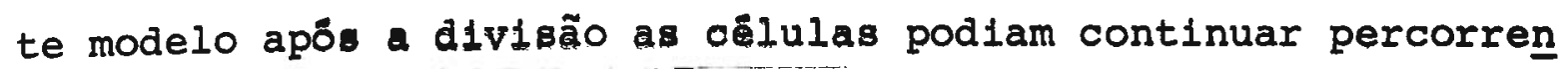
do o c1clo mitőt1co paseando por MGl, SG1, S, G2, etc ou sair do ciclo replicativo entrar am IGl.

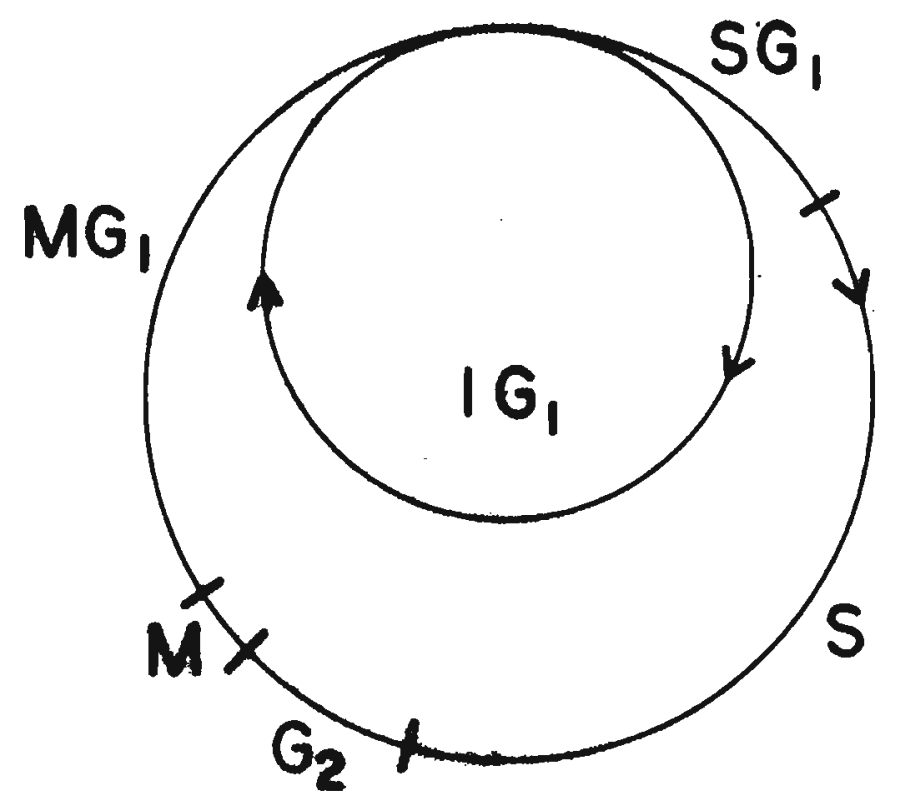

Fig. I: Modelo de clclo celular segundo TEMIN, 1971.

o concelto estätico de Go (como formulado por Lajtha) resultou em proposições mals dinâmicas. BURNS \& TANNOCK (1970) propuseram o modelo de ciclo celular esquematizado na fig. 2 no qual Go seria um estado pelo qual todas as cêlulas passariam 
necessariamente depois de M. As células sairiam de Go ao acaso e com probabilidade por unidade de tempo constante. Após deixar Go as cêlulas entrariam numa fase C (compreendida por G1 verdadeiro, S, G2 e M) de duração constante e que termina com divisão celular. No entanto estes autores se limitaram a tentar explicar o comportamento de tecidos que proliferam lentamente.
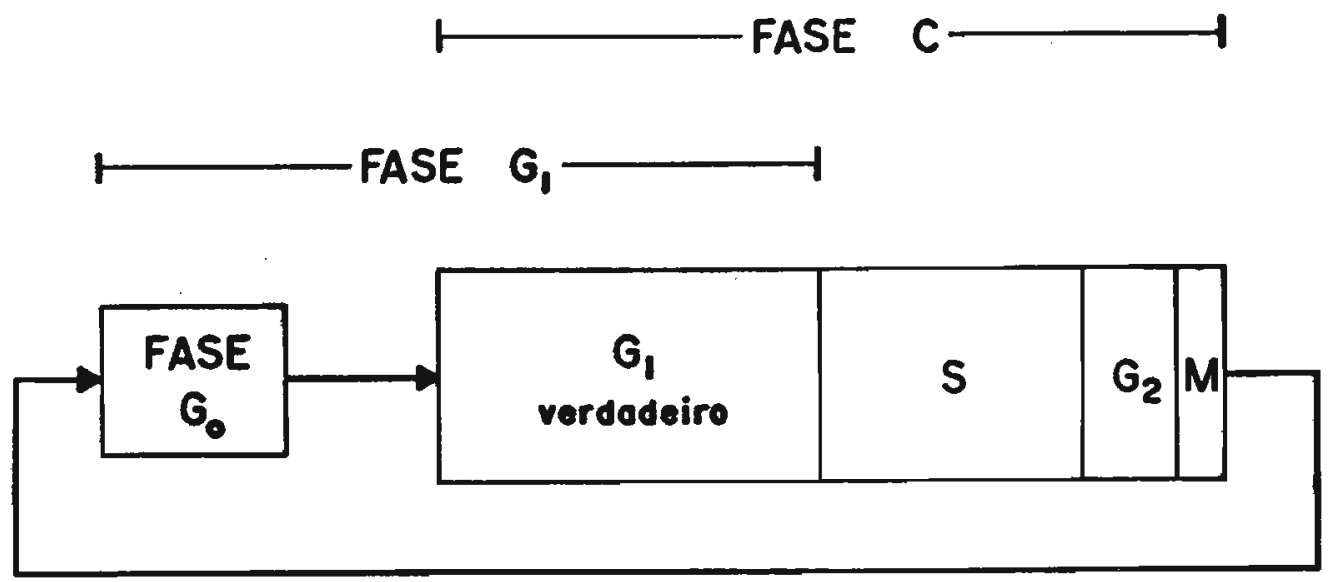

Fig. 2: Modelo de ciclo celular segundo BURNS \& TANNOCK,1973.

Outros autores (SMITH \& MARTIN, 1973), baseados em me didas do período intermitótı́co de células individuais, generalizaram o concelto dinâmico de Go para todos os tipos de cêlú las e sugeriram abandonar o modelo convencional de ciclo celular, substituindo-o por outro ( Hide fig. 3) no qual as células existiriam em dols estados fundamentalmente diferentes A e B. Após completar a mitose a célula entraria no estado A no qual sua atıvidade não estaria dirigida para replicação. Durante o tempo que a célula ficasse no estado A, a probabilidade de passar ao estado B permanecerla constante. As células 
deixariam o estado $A$ ao acaso passando para a fase $B$ onde suas atividades seriam determinîsticas e dirigidas para a replica ção e divisão celular. A velocidade de crescimento da popula ção dependeria então da probabilidade com que as células saem do estado A, da duração da fase B e da velocidade de morte celular.
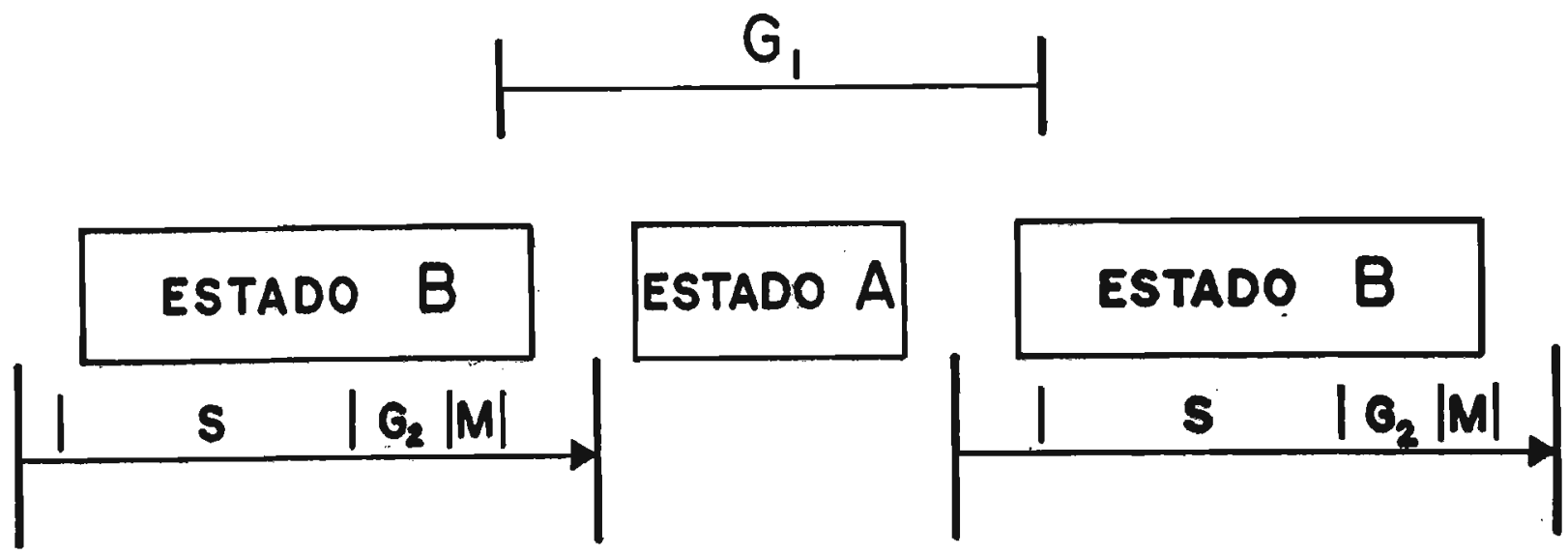

DETERMINADO INDETERMINADO DETERMINADO

Fig. 3: Modelo de ciclo celular segundo SMITH \& MARTIN,1973.

No modelo proposto por ARMELIN (1975), esquematizado na fig. 4 o estado fundamental da cêlula serta de repouso (es tado R) no qual o programa para divisão celular estaria desli gado. Este programa seria a soma das reações citolōgicas e bioquimicas que ocorrem de maneira sequenciada e que culminam com a divisão da cêlula em duas cêlulas filhas. As célux las podem salr do estado $R$ ao acaso e entrar no compartimento $P$ de cêlulas proliferativas as quais estariam compromet1 das com o programa de divisão celular. A entrada em P seria 


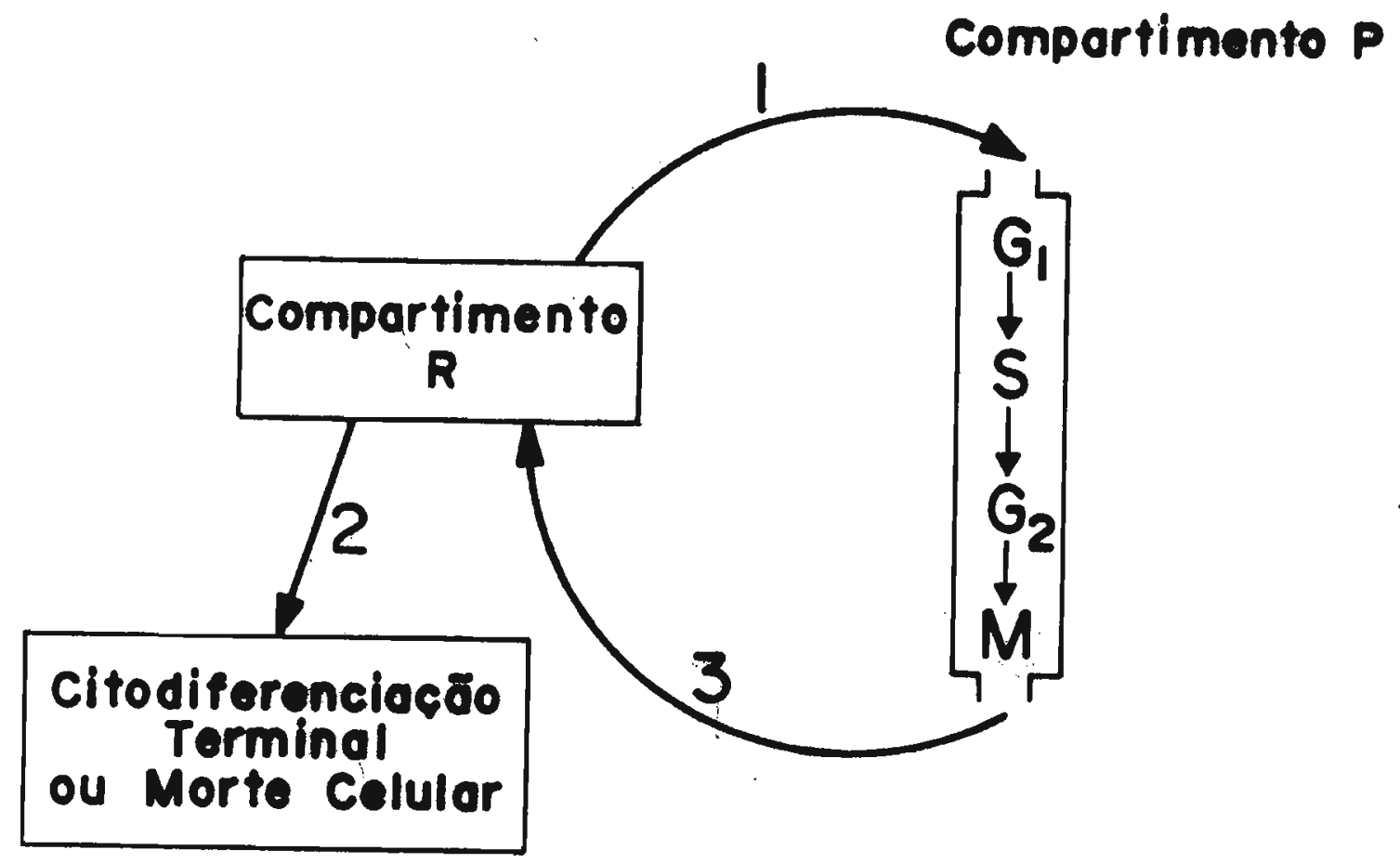

Fig. 4: Modelo do ciclo celular segundo ARMELIN, 1975.

única e estaria localizada no inf́clo de Gl. No caso de cêlulas em cultura a proliferação celular dependeria exclusivamente da probabilidade com que cêlulas fazem a transição de $R$ para $P$.

Implícito nestes mọelos está a importância atribulda a Gl - fase extremamente variãvel e complexa na qual deve se concentrar a regulação do ciclo celular.

Do que foi mencionado acima, parece razoâvel admitir-se que o comprometimento da cêlula para com a replicação do seu DNA seja o ponto critico no controle da proliferaçãopor tanto seria importante transformar esta idēia bãsica em uma hipôtese simples e passivel de teste experimental. Um modelo simples, porêm litil, da organização de Gl pode ser visto na fig. 5. A utilidade deste modelo reside no fato de permitir 


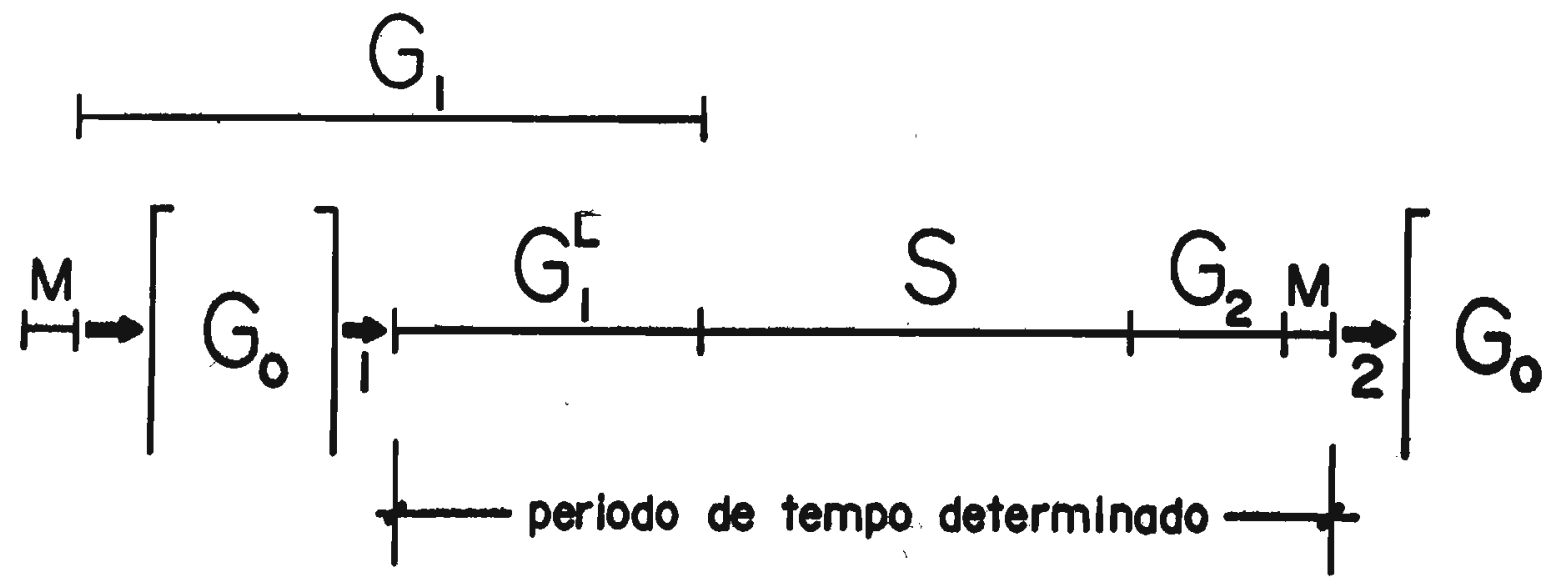

Fig. 5: Modelo de ciclo celular: hipótese proposta para a organização de Gl.

redução do controle do ciclo celular à regulação da transição Go $\rightarrow \mathrm{Gl}^{\mathrm{C}}$. Gl aqui è dividido em duas partes: Go e $\mathrm{Gl}^{\mathrm{C}}$ (Gl com prometido). Cêlulas em Go serlam equivalentes a células no estado $R$, no sentido de estarem no estado fundamental, em repou so e não comprometidas com a divisão celular. As cêlulas aí permaneceriam por tempo variāvel e sairiam daí ao acaso. Por outro lado $\mathrm{Gl}^{\mathrm{C}}$ se caracteriza por um comprometimento irreversivel com os processos de sintese de DNA e divisão celular. CéIulas que entram em $\mathrm{Gl}^{\mathrm{C}}$ progrediriam inexoravelmente por $\mathrm{s}$, G2 e M e as cêlulas flihas resultantes cairiam necessariamente em Go. O controle do ciclo celular seria então exercido ao nível da transição $G o+G^{C}$ (transição 1). Esta transição depende de reações que ocorrem ainda em Go podendo ser estimulada ou inibida por hormônios classicos ou fatores de crescimento do tipo hormonal.

Usando este modelo como hipōtese de trabalho procuramos investigar o comportamento cinêtico de dois sistemas diferent 
fibroblastos e células adrenais - frente a ação de seus efetuadores (fatores pituitārios, EGF, insulina, hidrocortisona, ACTH, etc). Os objetivos deste tipo de enfoque eram adquirir informa ções sobre o ponto do ciclo celular ao nivel do qual os efetuadores agem e seus modo de ação. Num primeiro protocolo, célula em repouso (estado R) foram estimuladas por efetuadores pos 1 tivos (soro ou hormônios estimuladores) procurando-se · observar o tempo que leva para instauração da onda de sintese de DNA e de que maneira este tempo e a amplitude da resposta são afetados pelo tipo e a quantidade do efetuador. E ainda adicio nar efetuador negativo e células estimuladas a fim de verificar quanto tempo após o estímulo (ou antes de S) as cēlulas tor nam-se insensíveis à ação do inibidor, ou seja, quando ficam comprometidas com o processo de sintese de DNA (transição Go $\rightarrow \mathrm{Gl}^{\mathrm{C}}$ ). Num segundo protocolo, cêlulas em crescimento expo nencial foram colocadas em condições em que o crescimento è in bido (atravês da carência de soro e/ou da adição de efetuadores negativos do tipo hormônio) procurando-se observar o que acontece com os parâmetros celulares (sintese de DNA, divisão celular) quando as cēlulas fazem a transição $R \rightarrow P$, ainda se os efetuadores são especificos para esta fase do ciclo celular.

Usando este tipo de enfoque chegamos às seguintes conclusões: a) os fatores que regulam o crescimento celular agem bloqueando ou estımulando o comprometimento das cêlulas com o processo de sintese de DNA (ou seja bloqueando ou estimulando a transição Go $\rightarrow G^{c}$ ); b) este comprometimento ocorre muito antes da fase $s ; c)$ o "steady-state" da proliferação è mantido 
atravēs da ação dinâmica de reguladores (positivos e negat1 vos) da transição $\mathrm{R} \rightarrow \mathrm{P}$ ou $\mathrm{Go} \rightarrow \mathrm{Gl}^{\mathrm{C}}$.

6. ANALISE GENETICA DE CELULAS DE MAMIFEROS EM CULTURA

o enfoque bioquímico tem alcance limitado. Acreditạ mos que o estudo de controle de crescimento seria enormemente facilitado se outros tipos de enfoque - o genētico, por exem plo - pudessem ser aliados ao bioquímico.

A anālise genética do ciclo celular, empreendida por Hartwell e colaboradores em levedura (ver revisão em HARTWELL, 1974) trouxe uma série de contribuições. Estes autọ res isolaram e caracterizaram mais de 2000 mutantes de s. cerevisiae. Cerca de 108 destes mutantes apresentavam lesões que afetavam o ciclo celular (mutantes cdc) e puderam ser agrupados em 32 grupos de complementação. A anāltse destes mu彑 tantes permitiu concluir que: a) os vārios eventos do clclo ce lular de levedura (sintese de DNA, brotamento, divisão da placa centriolar, migração do nücleo, cariocinese, citocinese e separação das cêlulas filha) díspōem-se em duas vias independen tes as quals divergem do mesmo ponto (localizado no inicio de Gl) e convergem para o mesmo ponto (citocinese); b) è na fase inicial de Gl que as cêlulas ficam sujeitas a sinais (efetuado res) que desencadeiam um ou outro processo do programa de desenvolvimento da levedura (melose, conjugação ou outro ciclo mitōtico). A ausêncla destes sinais implica na permanência de cêlulas na fase estacionária, antes de $S$ e, portanto, em Gl.

O modelo experimental usado por Hartwell apresenta aspectos extremamente favoräve1s: a) as fases do ciclo 
são facilmente identificadas pela morfologia da célula; b) como este organismo apresenta fases haplóide e diplôide, é possível mutagenizar células haplóides e identificar imediatamente mutações recessivas e ainda usar cêlulas diplóides para anālises de complementação.

E óbvio que no caso de células de mamíferos em cultura não estamos diante das condições favoráveis encontradas por Hartwell em levedura. Entretanto a procura de mutantes de célu las somãticas em cultura teve uma motivação muito grande, qual seja - levar a uma metodologla que permitisse a anālise genētica em mamiferos com eficiência semelhante àquela observada com microrganismos.

Vărlas têcnicas têm sido empregadas para o isolamento de mutantes somáticos, das quais destaca-se: a) suicídio com $\underline{B U d R}$ - introduzida e utilizada por PUCK \& KAO (1967) para o iso lamento de mutantes auxotróficos. O princípio aplicado è o mesmo da genética de microrganismos: uma população mista de células é colocada em meio limitado (na ausência de determinado nutriente) no qual as cêlulas que apresentam deficiêncla nutriclonal não crescem. A exposição ao agente seletivo (no caso BUdR) e, em seguida, à luz ultravioleta próxima, causa a morte apenas de células em crescimento (que incorporaram BUdR) enquanto aquelas incapazes de crescer na ausêncla do nutriente (e que, portanto, não incorporaram BUdR) sobrevivem, podendo ser recuperadas e 1soladas.

b) Seleção com FUaR (POLLACK et al, 1968). Estes autores verifica ram que quando populações de cêlulas de mamiferos eram expostas a FUdR,aquelas que estavam em proliferação eram mortas enquanto 
células que não estavam se dividindo não eram afetadas podendo, portanto, ser recuperadas. Este método se aplica ao isolamento de células mais sensiveis a qualquer tipo de controle de cresci mento, tendo sido usado por Pollack para o isolamento de rever tentes de cêlulas transformadas los chamados "flat mutants" por que, ao conträrto da linhagem parental, formam colônias achatadas, sem emplihamento de células).

c) Seleção atravēs de anālogos de purinas (SHARP, CAPECCHI \& CAPECCHI, 1973). A enzima hipoxantina fosforibosil transferase (HPRT) è responsável pela formação de IMP e GMP, à partir de guanina e hipoxantina, os quais vão ser utilizados na biossinte se de ácidoṣ nuclelcos. Fornecendo análogos de purinas (8-asaguanina ou 6-tioguanina) a uma população de cēlulas I foi possí vel 1solar mutantes HPRT ${ }^{-}$os quais sobrevivem ao tratamento devido ao fato dos nucleotideos püricos poderem ser sintetiza dos "de novo" na ausência de HPRT. A partir da linhagem HPRT' , revertentes $\mathrm{HPRT}^{+}$. puderam ser isolados atravês do bloqueio da sintese "de novo" de nucleotideos püricos com ametopterina e adição de hipoxantina ao meio. Nestas condições somente célū las $\mathrm{HPRT}^{+}$sobrevivem podendo ser recuperadas em melo contendo hipoxantina, ametopterina e timidina (chamado meio HAT).

O emprego destás têcnicas de seleção permitiu o isola mento de um grande nümero de variantes (auxotróficos, resistentes a drogas, etc). Porëm, multo cedo neste campo,a origem genëtica destas alterações foi questionada principalmente por HARRIS (1971) e MEZGER-FREED (1972). A base das criticas encon trava-se nos seguintes argumentos: a) alguns tipos de variantes não eram estáveis; b) as estimativas de taxas mutacionals 
disponíveis eram muito altas (da ordem de $10^{-3}$ ) e o emprego de agentes mutagênicos não permitia aumentā-las; c) a taxa de mutação parecła ser independente da ploidia, d) mutações recessị vas não deveriam aparecer em cêlulas que são no mínimo diplóides.

A qualidade e a interpretação dada aos dados disponí veis, entretanto, foram questionadas por DE MARS (1974) dissipando, assim, o cetiçismo em torno da origem genētica das altẹ rações encontradas. A questão ficou novamente em aberto mas dúvidas sobre a ocorrência de mutações recessivas em cêlulas que eram no minimo diplöides permaneciam. Entretanto apesar de anâlise cariotípica e medidas de conteûdo de DNA de células CHO (chinese hamster ovary) indicarem grande proximidade em re lação a cêlulas normais de hamster, evidências começaram a se acumular de que embora estruturalmente diplóides estas células mostravam-se funcionalmente hemizigotas para um grande nümero de genes (o que explicaria a ocorrência de tantas mutaçōes recessivas nesta linhagem).

Como mutações recessivas eram encontradas em vārıas outras linhagens e como a maloria delas era aneuplóide (com grande nümero de perdas e rearranjos cromossômicos) SIMMINOVITCH (1976) sugeriu a hemizogozidade parcial como um fenômeno generalizado entre cêlulas estabelecidas em cultura.

Tornou-se então Importante estabelecer critêrios para decidir, em cada caso, se a varlação podia ser aceita como devida a alteração genotípica ou tratavarse de um efeito epigenêtıco. Um critêrio importante è a taxa de mutação: ordem de grandeza, possibilidade de ser aumentada com agentes 
mutagênicos e dependência do grau de ploidia da célula. Enquan to os dols primeiros tềm sido observados num número razoāvel de casos, a dependêncla do grau de ploidia depende da dispontbilidade de linhagens com diferentes graus de ploidia o que só fol conseguido atē agora com linhagens de Rana (MEZGER-FREED, 1974) não havendo noticla atê agora de linhagem haplóide em células de mamiferos. A estabilidade fenotiplca è tomada como critērıo bãsıco para o estabelecımento de mutan tes mas o critērio mals objetivo e definitivo consiste na possibilidade de correlacionar a alteração fenotiplca com alterações do produto gênico (modiflcação estrutural de uma protelna). Exemplos deste tipo tem se acumulado nos ültimos anos.As sim,mutantes resistentes a azaguanina parecem ter mutações estruturais no gene para a enzima HPRT (SHARP et al., 1973) tendo sido possivel detectar reatividade dos extratos com anticor po contra HPRT (BEAUDET et al., 1973). O enzima N-acetilglico saminil transferase apresenta-se alterado em cëlulas resistentes a lectinas (STANLEY et a1., 1975; GOTTLIEB et al., 1975)e a resistência a ouabaina tem sido associada a alteração de uma ATPase dependente de sód1o e potássio (BAKER et al., 1974).

Mutantes condicionals letais de células de mamiferos só surglram â partır de 1973. THOMPSON et al. (1973) isolaram um mutante de células cHo que era temperatura sensível (ts) para crescimento e mostraram que os extratos destas cêlulas apresentavam atividade de leucil-tRNA sintetase tambēm ts. TONIOLO et al. (1973) isolaram um mutante ts para crescimento de células BHK2l com defelto 1dentificado como sendo no processamento do RNA ribossômico 28S. Estes autores mostraram 
ainda que os dois defeitos (crescimento e processamento do rRNA) eram devidos a uma única mutação uma vez que todos os revertentes (capazes de crescer à temperatura não permissiva) apresenta vam processamento normal do rRNA.

Mutantes de ciclo celular começaram a aparecer na lite ratura tambēm à partir de 1973. o protocolo básico usado tem sido o seguinte: a) mutagenização (nitrosoguanidina, etilenometa no sulfonato, compostos de acridina) de uma cultura em cresci mento exponencial e recuperação dos sobreviventes (cerca' de 10\%) à temperatura permissiva; b) transferência para a temperatura não permissiva e Incubação por tempo suficiente para ocorrer a expressão fenotíplca; c) aplicação do agente seletivo (BUdR, FUdR, Ara C, ${ }^{3}$ HTdR) à temperatura não permissiva provocando a morte de cēlulas em crescimento enquanto aquelas bloqueadas em algum ponto do ciclo sobrevivem; d) recuperação, clonagem e caracteriza ção dos sobreviventes.

A caracterização dos variantes envolve aliar têcnicas de sincronização com experiências de mudança de temperatura. A sincronização por carência de soro e nutrientes causa bloqueio em Gl; hidroxiuréia ou excesso de timidina são usados para obter células bloqueadas no inicio de $\mathrm{S}$ e colchicina para bloqueio em M. Os esquemas em geral consistem em sincronizar as cêlulas na temperatura permissiva e, apōs diferentes tempos, aliviar o bloquelo na temperatura não permissiva ou então sincronizar na temperatura permissiva, aliviar o bloqueio nesta mesma temperatura e, apōs diferentes tempos, passar para a temperatura não permissiva. A anãlise dos parâmetros celulares ē então feita pa ra identificar o tipo de lesão e o ponto do ciclo onde ocorre. 
Teoricamente deveria ser possivel, usando o protocolo acima descrito, obter variantes com bloqueios em todas as etapas do ciclo uma vez que estando bloqueadas (seja em G1, S, G2 ou M) não estarłam sujeitas à ação dos agentes seletivos empregados. No entanto dos inúmeros mutantes ts para crescimento cer ca de 8 têm sido bem caracterizados e destes, 4 flcam bloqueados em G1 (ROSCOE et al., 1973a; SMITH \& WIGGLESWORTH, 1973; SHEFFLER \& BUTTIN, 1973; IISKAY, 1974; BURSTIN et al., 1974; TENNER et al., 1977) 1 parece ter uma lesão que 1mpede a cêlula de fazer a transição de Gl para s ou seja flca bloqueada no limite GI/S. (SMITH \& WIGGLESWORTH, 1973) e 3 apresentam defeltos na mitose sendo uma bloqueada em metafase (WANG, 1974) e duas em c1tocinese (SMITH \& WIGGLESWORTH, 1972; HATZFELD \& BUTTIN, 1975). Portanto até o momento nenhum mutante para G2 ou $s$ fol encontrado.

ROSCOE et al. (1973b) desenvolveram outro mętodo para - 1solamento de celulas bloqueadas em qualquer ponto do c1clo, baseado na fac1lidade com que células mitótıcas despregam-se da superficie. Estes autores conseguiram isolar um mutante com bloqueio em G1 mas nenhum em $S, G 2$ ou $M$.

O problema båsico parece residir no fato dos protocolos ut1lizados para o isolamento de variantes exigirem a permanêncla de cêlulas em condlções desfavorávels por longos periodos de tempo. Cêlulas bloqueadas em Gl tertam maior chance de sobrevivêncla uma vez que GI lou, mals especificamente Infclo de Gl ou Go) constitul-se numa parada natural com balanceamento me tabōlico favorável. Alêm disso a porcentagem de cēlulas jovens (em GI) numa população em crescimento exponenclal ê bem malor 
do que cêlulas mals velhas ou seja em G2 ou M (PAINTER \& MARR, 1968). Parece óbvio que o emprego de tēcnicas de seleção em cëlulas previamente sineronizadas permitiria contornar estes pro blemas e aumentar a probabilidade de isolamento de mutantes G2 e s.

7. MUTANTES REGULATORIOS DO CRESCIMENTO CELULAR

O enfoque empragado por nọ̄ consistiu na busca de variantes de cêlulas somáticas que ou não respondem ou apresentam respostas diferentes a hormônios ou fatores de crescimento. A premissa bãsica ê que este tipo de vartante teria sistemas de controle parcialmente ativos, constituindo-se, assim, em bons candidatos a mutantes regulatốfios do mecanismo de controle de crescimento. Estes mutantes seriam ũteis não só para a identıfıcação de novos fatores de crescimento como tambëm para a caracterização e 1dentłfleaçăo dos componentes dos mecanismos de controle do crescimento.

E importante mencionar que o termo "variante" seră usado neste texto com o seguinte sentido: qualquer linhagem de cêe lulas com fenôtipo alterado em relação à linhagem parental, cujo fenotipo è mạtido por multaş gerações, mesmo apōs repetidas reclonagens, na ausêncla de qualquer agente seletıvo. Tałs "varıantes" não são necessarlamente mutantes no sentido genētico, entretanto, nesta tese, variante ou mutante serão usados como sinônimos sempre tendo em vista a definição operacional prọ posta acima.

Usando este tipo de enfoque pudemos isolar mutantes tanto do sistema fibroblasto como do sistema células adrenais.o 
mutante STl derıvado de fibroblastos $3 \mathrm{~T} 3$ apresenta uma série de caracteristicas extremamente interessantes entre as quais: perda de resposta a todos os reguladores positivos conhecidos pa ra a linhagem parental; b) aquisição de resposta inibitórı́a e, portanto, contrária à da linhagem parental, a glicocorticốdes; c) resposta estimulatórla frente a um fator de crescimento dife rente dos já conhecidos $e$, portanto, potencialmente um novo fator de crescimento; d) reversão fenotípica causada por um ünico hormônio: hıdrocortisona provoca mudança do padrão de crescimen to (do tipo transformado para um padrão normal) tanto "in vitro" como "In vivo" (quando as cēlulas são injetadas em animais); e) alterações morfolôglcas, provavelmente devidas a mudanças na su彑 perficle celular, causadas por hidrocortisona, retirada de soro ou adição de CAMP.

No sistema células adrenais a linhagem $\mathrm{Y}-1$ responde a ACTH com uma estımulação da função diferenclada-eștero1dogênese (SATO et al.,1970) acompanhada de inibição do crescimento (MASUI \& GARREN, 1971). Estes últimos autores verificaram ainda que o efeito inibitôrịo de ACTH nestas cêlulas pode sef mimetizado por adição de CAMP. Mutantes reșistentes a ACTH têm sido descri tos (SCHIMMER, 1969) nos quals, entretanto a resposta a CAMP ê mantida. Estes dados têm sido usados como evidências da mediação por CAMP dos efeltos causados por ACTH. Por outro lado, - mutante AR-1 isolado por nōs à partir de céḷulas Y-l,embora tambēm resistente a ACTH (quanto à resposta inibitória do crescimento), não responde à adıção de CAMP. A adição de ACTH a cêlulas AR-1 provoca entretanto uma estimulação do crescimen to, sugerindo a existência de outra via, alēm da mediada por CAMP, para a ação do hormônio. 
A exploração destes mutantes e estudos comparativos com as linhagens parentais permitiram a obtenção de informações relevantes sobre os componentes do sistema de controle de crescimento e seus mecanismos de ação. 
II. MATERIAL E METTODOS

\section{LINHAGENS DE CELULAS}

Tabela I: Propriedades das linhagens estabelecidas utilizadas

\begin{tabular}{|c|c|c|c|c|}
\hline Linhagem & Tipo & Origem & $\begin{array}{c}\text { NQ de } \\
\text { omos./célula }\end{array}$ & Comportamento \\
\hline $\begin{array}{l}\text { 3T3 (Swiss) } \\
\text { (TODARO \& } \\
\text { GREEN, 1963) }\end{array}$ & fibroblasto & $\begin{array}{l}\text { Embrião } \\
\text { de camun } \\
\text { dongo }\end{array}$ & $80 \pm 2,5$ & "normal" \\
\hline $\begin{array}{l}\text { SV3T3 (SwIss) } \\
\text { (TODARO \& } \\
\text { GREEN, 1964) }\end{array}$ & fibroblasto & $\begin{array}{l}\text { Embrião de } \\
\text { camundongo } \\
\text { transforma } \\
\text { das (em cul } \\
\text { tura) por } \\
\text { virus SV40 }\end{array}$ & $75,6 \pm 4,8$ & tumorogênica \\
\hline $\begin{array}{l}\mathrm{Y}-1 \\
\text { (YASSUMURA } \\
\text { et al.,1966) }\end{array}$ & adrenal & $\begin{array}{l}\text { Tumor fun- } \\
\text { cional de } \\
\text { camundongo }\end{array}$ & $36,5 \pm 4,0$ & $\begin{array}{l}\text { tumorogênica } \\
\text { sintetiza cetos } \\
\text { teróides respon } \\
\text { de a ACIH }\end{array}$ \\
\hline
\end{tabular}

Os estoques das linhagens $3 \mathrm{~T} 3$ e $\mathrm{Y}-1$ foram iniciados à par tir de amostras obtidas da American Type Culture Collection (Rockville, Maryland, Estados Unidos) e a linhagem sv3T3 foi obtida do laboratório do Dr. R. Bulbecco (Salk Institute, La Jolla, California, Estados Unidos). Amostras destas e de outras linhagens são mantidas congeladas em reservatōrio de nitrogênio líquido. 
2. MEIOS E CONDIÇÕES DE CULTURA

o meio de cultura consiste numa fração quimicamente definida e uma fração complexa. A parte quimicamente definida consistiu de DME '("Dulbecco's modified Eagle's medium") adquirido sob a forma de pó da Grand Island Blological Co., New York (Gibco), suplementado com $1,2 \mathrm{~g} / 1$ de bicarbonato de sódio, $5 \times 10^{5}$ unidades de penicilina/l, $25 \mathrm{mg} / \mathrm{l}$ ampicilina e $100 \mathrm{mg} / 1$ estreptomicina. Após dissolução em água bidestỉla da este meio era esterilizado por filtração através de filtros Millipore (poros 0,22 $\mu$ ), distribuído em garrafas de vidro de $100 \mathrm{ml}$ e armazenado na geladeira por não mais que 2 me ses. A fração complexa do meio de cultura é representada por soro. Neste trabalho foram utilizadas diferentes partidas de 2 tipos de soros: de vitelo (CS) e fetal bovino (FCS) adquiri dos da Gibco, New York ou da Flow Laboratories, Colorado. Ini cialmente adotou-se inativar o soro ( 1 hora à $55^{\circ} \mathrm{C}$ ) mas com o desenrolar deste trabalho verificou-se não ser isto necessārio passando-se, então, a dividir o conteúdo de uma garrafa de 0,51 em pequenas aliquotas $(10 \mathrm{ml})$ que eram mantidas congeladas atē o momento de serem utilizadas.

Os estoques foram mantidos em melo dito $10 \%$ FCS DME (10\% de soro fetal bovino + 908 DME) ou meio $5+5 \mathrm{DME}$ (5\% de soro fetal bovino +58 soro de vitelo $+908 \mathrm{DME})$. Estes meios eram preparados imediatamente antes do uso por mistura de soro e DME em condições estéreis.

As culturas estoque foram mantidas em frascos de ví dro com tampa de baquelite enquanto que para experiências as 
células eram semeadas (plaqueadas) em placas de Petri de vidro ou de plástico do tipo descartável (Falcon Plastics, Califor nia) ou em lamínulas $\left(3,2 \mathrm{~cm}^{2}\right)$. As placas de plāstico eram recicladas por lavagem e esterilização por luz ultravioleta.

Culturas em placa foram mantidas em caixas de plästi co transparente (ATMA) adaptadas a funcionar como câmara ûmida através de uma camada de espuma $(0,5 \mathrm{~cm}$ espessura) embẹ bida em āgua que era colocada no fundo da caixa. Mistura de $5 \% \mathrm{CO}_{2}+95 \%$ ar comprimido era injetado e a caixa, devidamente vedada com vaselina, era incubada a $37^{\circ} \mathrm{C}$. Esta mesma mistura de gases era injetada nos frascos de cultura estoque os quais eram incubados também a $37^{\circ} \mathrm{C}$.

Medidas severas de segurança foram adotadas na rotina do laboratório para evitar contaminação por microrganismos (bactërias, fungos ou Mycoplasma) e também para impedir contaminações cruzadas entre linhagens de células.

\section{MANUTENÇÃO E CONGELAMENTO DE ESTOQUES}

A subcultura dos estoques era feita por inoculação de meio fresco com alíquotas de uma suspensão homogênea de cêlulas. Esta suspensão era obtida atravês da remoção do melo veIho, lavagem da camada de cêlulas com solução salina fosfato sem $\mathrm{Ca}^{2+}$ e $\mathrm{Mg}^{2+}$ (PBSA) e tripsinização com solução salina contendo 0,18 tripsina (Nutritional Biochemicals) e $1 \mathrm{mM}$ EDTA.

Para o congelamento de estoques, alíquotas de $1 \mathrm{ml}$ de uma suspensão homogênea de células $\left(1-2 \times 10^{6}\right.$ células $\left./ \mathrm{ml}\right)$ em meio de cultura + 108 DMSO (Riedel-de Haßn AG Seelze-Hannover) 
eram distribuídas em ampolas de vidro ou tubos de plástico com tampa rosqueável'. Depois de devidamente vedados as ampolas ou tubos eram incubados por $30 \mathrm{~min}$ a $4^{\circ} \mathrm{C}$, transferidos para um congelador à $-70^{\circ} \mathrm{C}$ (Virtis Deep Freezer, The Virtis Co., New York) por 24 horas e daí mergulhados no reservatório de nitro gênio líquido (LR-2l, Union Carbide).

\section{CONTAGEM DE CÉLULAS}

Suspensões homogêneas de células, obtidas por tripsinização conforme descrito no item 3 eram contadas em hemocitô metro (câmara de Neubauer) ou Contador Coulter (Coulter Electronics). Neste último caso diluições apropriadas eram feitas em PBSA (para evitar aglutinação das células) e contadas na faixa de $10^{3}$ a $10^{4}$ células/ml onde a linearidade e a equivalência com contagens feitas em hemocitômetro era maior.

5. MEDIDAS DE INCORPORAÇÃO DE TIMIDINA ${ }^{3} \mathrm{H}$ EM DNA

Timidina ${ }^{3} \mathrm{H}(48,5 \mathrm{ci} / \mathrm{mmole})$ da New England Nuclear era adicionada ao meio de cultura numa concentração final varí āvel dependendo do tipo de experiência. Decorrido o tempo de incorporação o meio era removido e TCA 5\% adicionado para extração do material ācido solúvel. Após incubação por 15 minụ tos à frio $\left(4^{\circ} \mathrm{C}\right)$ o TCA era removido e as células dissolvidas em pequeno volume de $\mathrm{NaOH} 0,5 \mathrm{~N}(0,5 \mathrm{ml}$ por placa de $35 \mathrm{~mm}$ ou $1 \mathrm{ml}$ por placa de $60 \mathrm{~mm})$. Uma alíquota $(0,1-0,3 \mathrm{ml})$ deste material era aplicado em filtro de papel whatman no $17\left(4 \mathrm{~cm}^{2}\right)$. Os filtros eram lavados em TCA 5\% à frio, álcool $95 \%$ e acetona 
e, depois de secos, mergulhados em líquido de cintilação (4 g/l PPO + 0,1 g/l POPOP dissolvidos em tolueno). A radiatividade incorporada em DNA era então determinada usando-se Con tador de Cintilação em meio Iíquido modelo LS, Beckman Instruments Inc. (Palo Alto, California, E.U.A.).

6. AUTORRADIOGRAFIA E TESTE PARA DETECÇÃO DE MICOPLASMA

A incorporação de timidina ${ }^{3} \mathrm{H}$ era feita como descrî to para o item anterior. Após incorporação, as células, ade ridas à superfície da placa, eram submetidas a dois tratamen tos com TCA 58 (15 minutos, $4^{\circ} \mathrm{C}$ ), lavadas com etanol 958 e secas ao ar. As placas eram cobertas com filme Kodak AR-10, expostas por tempo variävel, reveladas (Revelador D19b), coradas com Giemsa 108 e observadas ao microscópio para determinação do Indice de marcação (número de núcleos marcados/nú mero de células).

Todas as linhagens de células eram testadas periodí camente para a presença de Mycoplasma através de métodos autorradiográficos já estabelecidos (NARDONE et al., 1965; STUDZINSKI et al., 1973).

\section{MEDIDAS DE EFICIENCIA DE PLAQUEAMENTO}

A viabllidade das células numa dada população fol estimada através de sua capacidade de formar colônias. Para tanto uma suspensão homogênea de células era preparada (conforme descrito no item 3 destá seção) e a concentração de células determinada por contagem no homocitômetro. Após 
diluição seriada as cēlulas eram plaqueadas em baixa densidade (100 - 300 células/placa $60 \mathrm{~mm}$ de diâmetro) em meio rico (10\% soro DME) e o crescimento acompanhado por 7-10 dias.Após este período as células eram fixadas com formaldeido $10 \%$, coradas com cristal violeta 18 e o número de colônias com mais de 50 células era determinado por contagens à olho nú. A efí ciência de plaqueamento é dada pela relação nứmero de colônias desenvolvidas/nümero de células plaqueadas.

8. ClONAGEM de CELULAS (SEgundo O METOdo CLASSico DE PUCK \& MARCUS, 1955)

- Após obtenção de colônias (como descrito no item 7), algumas delas eram selecionadas e marcadas, sob microscópio de fase, com auxilio de pincel mágico de ponta fina. 0 meio de cultura era removido e a placa lavada com PBSA. Após a remoção do PBSA, pequenos anēis de vidro (4 mm diâmetro) previamente esterilizados em placa de Petri contendo uma fina ca mada de graxa de silicone (Corning Co.), eram colocados ao re dor da colônta demarcada. o bordo engraxado do anel permite adesão do mesmo à placa e impermeabilização e isolamento da colônia. Em seguida algumas gotas de tripsina $(0,18)$ era adicionado a cada un dos anéis e a placa incubada por alguns minutos a $37^{\circ} \mathrm{C}$ para remoção das células da superficie. Com - auxilio de uma pipeta pasteur o conteúdo de cada um dos anēis (com as cêlulas correspondentes a um única colônia) era transferido para uma placa de Petri pequena $(35 \mathrm{~mm}$ de diâme tro) contendo meio de cultura fresco. Após incubação. por 
alguns dias esta placa era tripsinizada e o processo era repe tido (reclonagem) para garantir a origem à partir de uma única colônia.

9. DETERMINAÇÃO DO INDICE MITÓTICO

Cêlulas aderidas à superfície de placas ou lamínu las eram fixadas em TCA 5\% ou formol 10\%, coradas com Giemsa 108 e observadas ao microscópio. O indice mitótico era determinado atravēs da relação: número de células mitóticas/númeto total de células após a contagem de no mínimo 2000 células/placa.

10. DETERMINAÇÃO DO CARIÓTIPO DE UMA LINHAGEM DE CELULAS (SE GUNDO METODO DE HSU \& POMERAT, 1953)

Para a determinação do número médio de cromossomos por célula, colchicina (Sigma Chem. Co.) numa concentração de $0,1 \mathrm{~g} / \mathrm{ml}$ era adicionada a culturas crescendo exponencialmente as quais eram incubadas por $1 \mathrm{~h}$ a $37^{\circ} \mathrm{C}$. Ao final deste período as cēlulas eram tripsinizadas, lavadas com PBS para remoção da tripsina e suspensas em solução hipotônica ( $\mathrm{KCl}$ 0,56\%). Após 15 minutos à temperatura ambiente as células eram fixadas por sucessivas lavagens com mistura de metanol-ācido acético $(3: 1)$ e centrifugação. o sedimento final de células era ressuspenso em pequeno volume $(0,2-0,5 \mathrm{ml})$ do fixador e a suspensão aplicada a lâminas previamente tratadas com metanol. As placas metafāsicas eram observadas ao microscópio de fase e o número médio de cromossomos determinado após contagem de pelo menos 50 destas placas. 
11. ENSAIO DE CRESCIMENTO EM SUSPENSÃO

o protocolo adotado foi uma modificação do método estabelecido por STOKER, 1968. Placas de agar sólido 10,98 agar em 10\% FCS DME) e meio metocel (18 metilcelulose em 10\% FCS DME) eram preparados com antecedência. Culturas em crescimento exponencial eram tripsinizadas e a concentração da suspensão determinada por contagens no hemocitômetro. Di luições seriadas desta suspensão foram feitas em meio meto cel e as células foram plaqueadas nas placas de agar em $4 \mathrm{ml}$ de meio metocel nas seguintes densidades: $10^{6}, 10^{5}, 10^{4}, 10^{3}$ e $10^{2}$ células/placa. As placas eram realimentadas semanal mente atravēs da remoção cuidadosa do meio velho e adição de 5-10 ml de melo metocel fresco. Como as células crescem na interface agar-metocel este procedimento não altera a distri buição das células ou o desenvolvimento das colônias. o número de colônias visiveis à olho nú era determinado (normalmente após 21 dias de incubação) com auxilıo de uma całxa escura provida de Iluminação lateral.

\section{ESTABELECIMENTO DE UMA COLONIA DE CAMUNDONGOS "NUDE"}

Camundongos "nude" são mutantes atímicos que possuem sistema imunológico extremamente reduzido devido a ausência de linfócitos do tipo T. Desde seu isolamento (ISAACSON \& CATTANACH, 1962; FLANAGAN, 1966) estes animais têm sido utilizados para ensaios de tumorogenicidade uma vez que não apresentam os incovenientes de rejeição devidos à presença de de antigenos de histocompatibilidade. 
A colônia foi iniciada à partir de animais (do tipo Swiss) trazidos do laboratōrio do Dr. Gordon Sato (Universida de da California San Diego, La Jolla, California, Estados Uni dos). Normalmente estes animais são mantidos por cruzamento entre macho homozigoto ( $\mathrm{nu} / \mathrm{nu}$ ) com fêmea heterozigota ( $\mathrm{nu} /+$ ) da mesma linhagem (RYGAARD, 1973). Como não dispunhamos da linhagem Swiss da qual os animais se originaram optamos por cruzar os homozigotos entre si.

A baixissima resistência destes animais à infecções exigiu condições especiais de manutenção. Os animais eram man tidos em sala a mais assēptica possível, à temperatura cons tante, em gaiolas especiais providas de filtro de ar. Gaiolas, forragem (palha de pinho), garrafas de água, ração, etc eram autoclavados e os animais manuseados em condições assépticas.

Como a fêmea "nude" tem a tendência a atacar e comer seus próprios filhotes, logo após o nascimento estes filhotes eram transferidos para gaiolas contendo fêmeas normais da linhagem $A$ que haviam tido filhotes na mesma época. Os filhotes "nude" eram criados pela mãe adotiva até os 21 dias de idade sendo, dai para a frente, mantidos em grupos de não mais de 4 animais/gaiola em condições especiais. A alimentação dos animais consistia de ração (Produtor no 49, Anderson Clayton $\mathrm{S} / \mathrm{A}$ ) autoclavada, aveia em flocos e leite em pó, sendo suplementada por complexo vitamínico.

Apesar do tipo de cruzamento adotado acarretar em fertilidade reduzida, as ninhadas eram em média de 12 e os 
animais apresentaram sobrevida relativamente alta (por volta de 400 dias).

13. ENSAIO DE TUMOROGENICIDADE E ANALISE HISTOPATOLOGGICA DOS TUMORES

Uma suspensão homogênea de células era obtida por tripsinização de uma cultura subconfluente. Allquotas de $0,25 \mathrm{ml}$ desta suspensão (contendo $1-2 \times 10^{6}$ células) eram injetadas na região escapular de camundongos "nude" de 4 sema nas. Crescimento tumoral era seguido por palpação periōdica. Ao final de uma expertência os animais eram sacrificados e os tumores cuidadosamente dissecados, pesados e fixados em formaldeido 108 para posterior análise histopatológica.

Análise histopatológica era feita por observação ao microscópio de cortes de $3-4 \mu$ de espessura corados com hema toxilina-eosina.

14. DETERMINAÇÃO DO CONTEODO INTRACELULAR DE CAMP PELO METODO DE GILMAN (1970)

As culturas foram feitas em placas de vidro $(9 \mathrm{~cm}$ di diâmetro). Uma placa de cada vez era colocada em gelo picado e, após rápida remoção do meio, a superfície celular era lava da com PBS à frio e $3 \mathrm{ml}$ de TCA 5\% adicionado por placa a qual era então incubada por 30 minutos ã $4^{\circ} \mathrm{C}$. Ao cabo deste periodo o extrato ảcido era transferido para um tubo cônico com tampa rosqueável. Para eliminação de TCA do extrato, $6 \mathrm{ml}$ de ēter gelado previamente saturado com āgua eram 
adicionados por tubo. Após adição de HCl numa concentração fí nal de $0,1 \mathrm{~N} \circ$ tubo era agitado mecanicamente por 5 minutos à frio. A extração com éter êra repetıda mais 4 vezes e o éter residual da amostra eliminado por evaporação. 0 extrato aquoso era então congelado em nitrogênio líquido e l1ofilizado (New Brunswick Scientific Lyophilizer, New Brunswick, New Jersey, E.U.A.). A amostra liofilizada correspondente a uma placa era dissolvida em $250 \mu \mathrm{l}$ de $\mathrm{H}_{2} \mathrm{O}$ bidestilada e alíquo tas de $25 \mu 1$ eram usadas para determinação da quantidade de CAMP por placa. Após extração com TCA as placas eram lavadas com etanol 958 e as células dissolvidas em NaOH 0,5 N.Amos. tras deste.material eram usadas para determinação de proteína pelo método de LOWRY, 1951.

o ensaio de CAMP era feito num volume final de $210 \mu 1$ com a seguinte mistura de reação: tampão acetato de sódio 50 $\mathrm{mM} \mathrm{pH} 4,0 ; 1,5$ pmole de cAMP ${ }^{3} \mathrm{H}(10.000 \mathrm{cpm}), 50 . \mu \mathrm{g}$ de inibi dor de proteina quinase e amostras do extrato celular. A reação era iniciada por adição de 1 g de proteína quinase e incụ bada por 90 minutos à $4^{\circ} \mathrm{C}$. Após interrupção da reação por diluição com tampão fosfato de potãssio $20 \mathrm{mM} \mathrm{pH} 6,0$, a mistura era filtrada em filtros de nitrocelulose Millipore do tipo HA $(0,45 \mu)$. Os filtros eram extensivamente lavados com tampão fosfato e, depois de secos, a radiatividade determinada em aparelho de cintilação (Beckman).

Proteína quinase e inibidor de proteína quinase, preparadas à partir de músculo de coração de boi pelos métodos de MIYAMOTO et al., 1969 e APPLEMAN et al., 1966 respectivamen te, foram gentilmente cedidos pela Dra. Lêlia Mennucci (deste Departamento). 
As determinações de CAMP eram feitas atravēs de uma curva padrão de cAMP que seguia concomitantemente.

15. PURIFICAÇÃO DE FATORES DE CRESCIMENTO DA PITUITARIA (PF)

A obtenção do PF utilizado neste trabalho esteve principalmente a cargo de A.G. Gambarini e H.A. Armelin. o processo de purificação encontra-se descrito em ARMELIN et al. $(1976,1977)$ e compreende as seguintes etapas: glându las pituitárias congeladas de boi, adquiridas da Companhia de Alimentos do Brasil, eram homogeneizadas em mãquina de moer carne do tipo industrial e o homogeneizado era suspenso em $\left(\mathrm{NH}_{4}\right)_{2} \mathrm{SO}_{4} 0,15 \mathrm{M} \mathrm{pH} \mathrm{4,5}$. Após remoção do material fibroso por filtração em gaze e de partículas grandes por centrifuga ção $\circ \mathrm{pH}$ do sobrenadante era ajustado para $7,0 \operatorname{com} \mathrm{NaOH} 2 \mathrm{~N}$. Esta suspensão corresponde ao extrato cru cujo pH era ajustado para 3,0 com $\mathrm{HPO}_{3} 0,5 \mathrm{~N}$. O precipitado, coletado por cenErifugação, não tinha atıvidade sendo então descartado. sobrenadante era ajustado para $\mathrm{pH} 7,0$ e precipitado $\operatorname{com}\left(\mathrm{NH}_{4}\right)_{2} \mathrm{SO}_{4}$ 55\%. Após coleta do precipitado $\left(\mathrm{P}_{2}\right)$, a concentração de $\left(\mathrm{NH}_{4}\right)_{2} \mathrm{SO}_{4}$ era aumentada para 1008 e o precipitado $\left(\mathrm{P}_{3}\right)$ nova mente coletado. Ambos os precipitados de $\left(\mathrm{NH}_{4}\right)_{2} \mathrm{SO}_{4}$ eram ricos em atividade e apresentaram atividades especificas muito semelhantes, razão pela qual a precipitação com sulfato de amônio 55\% foi considerada etapa desnecessāria. Os precipitados de sulfato de amônio eram dissolvidos em àgua, dialisados,concentrados por ultrafiltração e liofilizados.o material liogilizado era dissolvido em tampão fosfato $0,005 \mathrm{M} \mathrm{pH} \mathrm{6,0} \mathrm{e} \mathrm{aplicado} \mathrm{a} \mathrm{uma}$ coluna de carboximetil sephadex c-50. Eluição era feita por 
aumento descontínuo da força iônica; assim quase toda a protel na era eluída em atē $0,1 \mathrm{~N}$ de $\mathrm{NaCl}$ enquanto a atividade permanecia adsorvida. Esta atividade era eluida somente com $\mathrm{NaCl}$ 1 M. A fração correspondente a NaCl $1 \mathrm{M}$ era dialisada, liofilizada e chamada PF (fator ou fatores de pituitária). A prepa ração de $\mathrm{PF}$ consiste num pó branco que è rapidamente solúvel em àgua e contēm 7-8 bandas de proteina por eletroforese em gel de poliacrilamida a $\mathrm{pH} 4,5$.

16. TRATAMENTO DE ENZIMAS, SORO E FATORES DE CRESCIMENTO COM PMSF

Solução fresca de PMSF $10 \mathrm{mg} / \mathrm{ml}$ em etanol $95 \%$ era adi cionada às soluções a serem tratadas para concentração final de $1 \mathrm{mg} / \mathrm{ml}$. Apōs incubação $\left(4\right.$ horas, $37^{\circ} \mathrm{C}$ ) as soluções eram dialisadas contra PBS +58 etanol e depois contra PBS, à $4^{\circ} \mathrm{C}$. Paralelamente alíquotas das mesmas soluções eram'tratadas da mesma maneira porēm na ausência de PMSF. As soluções eram fe1 tas em PBS nas seguintes concentrações: PF $1 \mathrm{mg} / \mathrm{ml}$; soro fetal bovino (FCS) 258 , trombina $5 \mathrm{mg} / \mathrm{ml}$ e tripsina $300 \mu \mathrm{g} / \mathrm{ml}$. Este tratamento inativa totalmente tripsina (tendo como substrato azocaseina) e trombina (usando como indicador a coagula ção de fibrinogênio).

17. PROTOCOLO PARA OBTENÇÃO DE CELULAS CARENCIADAS PARA SORO OU CELULAS EM REPOUSO

Culturas subconfluentes eram tripsinizadas para obten ção de uma suspensão homogênea de células. Diluições apropriadas 
eram feitas e as células eram plaqueadas em meio de cultura cọn tendo 3-5\% de soro numa densidade de $1-2 \times 10^{4}$ células/cm ${ }^{2}$. Após 24 horas as culturas eram lavadas com solução salina fosfato (PBS), meio 0,2\% FCS DME era adicionado e a incubação prosseguia por 24 horas. Ao fim deste período as células estavam carenciadas para soro, apresentando uma população enriquecida em células em repouso (ou cêlulas Go). Estas culturas carencladas foram usadas regularmente para ensaios de atividade estimulatória da sintese de DNA.

18. ENSAIO PARA MEDIDA DA ATIVIDADE ESTIMULATÓRIA DA SINTESE DE DNA

Cêlulas carenciadas para soro (em repouso) eram obtidas como descrito no item 17. Soro, hormônios ou fatores,cujas atividades desejava-se testar, eram adicionados a estás culturas. 12 horas após, timidina ${ }^{3} \mathrm{H}\left(0,25 \mu \mathrm{c} / \mathrm{ml} ; 10^{-7} \mathrm{M}\right)$ era adicionada e a incorporação prosseguia por 12 horas. Ao final deste período as células eram coletadas para medida da incorporação de timidina ${ }^{3} \mathrm{H}$ em DNA (conforme o item 5 desta seção) ou do Indice de marcação (conforme item 6 desta seção).

19. PROTOCOLO BÁSICO PARA TESTE DE VARIANTES

Usando o protocolo descrito no item procurava-se testar a resposta a soro (5 ou 10\%), hidrocortisona, insulina, PF e combinações dos mesmoas. No caso da resposta apresentada ser igual à da célula parental o clone era descartado, porēm, qualquer resposta alterada era explorada atē poder-se 
estabelecer e caracterizar o clone como variante.

20. PROTOCOLO PARA DETERMINAÇÃO DO TAMANHO DA FASE PRE-REPLICA TIVA (Gl)

Células em repouso eram obtidas como descrito no item 17 desta seção. Soro, hormônios ou fatores de crescimento eram adicionados ao mesmo tempo que timidina ${ }^{3} \mathrm{H}\left(0,5 \mu \mathrm{c} / \mathrm{ml}, 5 \times 10^{-7} \mathrm{M}\right)$ no tempo zero. Após diferentes intervalos de tempo e por um período de 24 horas, amostras eram coletadas para medida da incorporação de timiaina ${ }^{3} \mathrm{H}$ em DNA(item 5) ou do indice de marcação (item 6).

21. PROTOCOLO PARA MEDIDA DA QUEDA DE SINTESE DE DNA

Culturas subconfluentes em crescimento exponencial na presença de meio de cultura contendo 58 de soro, eram lavadas com PBS e o meio mudado para 0,28 de soro ou para meio sem soro. Após diferentes intervalos de tempo e por um periodo de 24 horas, pulsos $\left(0,5-1,0\right.$ hora) de timidina ${ }^{3} \mathrm{H}$ (1 $\left.\mu \mathrm{c} / \mathrm{ml} ; 48,5 \mathrm{Cl} / \mathrm{mM}\right)$ eram feitos em parte das culturas para determinação da incorporação de timidina ${ }^{3} \mathrm{H}$ em DNA (item 5 ) ou do Indice de marcação (item 6).

22. HORMONIOS, ENZIMAS, INIBIDORES E OUTROS REAGENTES

Preparações impuras de hormônio luteinizante (LH), es timulador do folículo (FSH), estimulador de tiróide (TSH), de crescimento (GH) e prolactina, fornecidos gratuitamente pelo U.S. 
National Institutes of Health (NIAMD Hormone Distribution Program) eram dissolvidos em PBS pH 7,0 em concentrações de $100 \mathrm{\mu g} / \mathrm{ml}$ e mantidas congeladas. Insulina de porco cristalina (Sigma Chem. Co.) dissolvida em solução salina pH 3,5 para $100 \mathrm{\mu g} / \mathrm{ml}$ era também mantida congelada. Estradiol, Dexametaso na, Androstan, 1-Dehidrotestosterona e 11-Deoxycorticosterona eram da Sigma Chem. Co, enquanto Hidrocortisona provinha da Nutritional Biochemical Corp. e Progesterona e Testosterona da Calbiochem. Todos os esteröldes eram dissolvidos em etanol 95\% a $500 \mu \mathrm{g} / \mathrm{ml}$ e mantidos na geladeira. Adrenocorticotropina (ACTH) Acthar da Armour Pharmaceutical Co. era dissolvida em PBS pH 7,0 a $12 \mathrm{U} / \mathrm{ml}$. Fator de crescimento epitelial (EGF) foi preparado segundo COHEN (1962); Somatomedina B parcialmente purificada e Somatomedina C altamente purificada foram gentilmen te cedidas pelo Dr. J. Van Wyck. Prostaglandina $\mathrm{F}_{2 \alpha}$ (sal de trometamina) era da The Upjohn Co.

Tripsina cristalina era um produto da sigma enquanto a preparação ativa de trombina foi purificada e gentilmente cedida pelo Dr. J.R. Giglio (Universidade de são Paulo, Ribel rão Preto, são Paulo). O inibidor de protease PMSF (fluoreto de fenilmetilsulfontla) fol gentilmente cedido pelo Dr. J.C.C. Maia (deste Departamento). BAPNA ( $\alpha-\mathrm{N}$-benzo11-DL-arginina-p-nitroanilida $\mathrm{HCl}$ ), azocaseina e azoalbumina foram gentilmente cedidos pelo Dr. E.P. Camargo (Escola Paulista de Medicina, são Paulo).

Nucleosideos (timidina), nucleotídeos (CAMP, dibutiril CAMP, 5'-AMP, CGMP), Teofilina, Colchicina e Cicloheximida 
eram da Sigma Chem. Co. e Citocalasina B foi adquirida

Aldrich Chem. Co. Inc.

As frações de soro bovino $(\alpha, \beta$ e $\gamma$ Globulina, Albumi na e fibrinogêniol eram da Nutritional Biochem. Co. 
III. RESULTADOS

1. ATIVIDADE ESTIMULATORIA DA SINTESE DE DNA POR SORO E FATORES DE CRESCIMENTO

\subsection{Atividade de Soro}

A atividade estimulatória de soro foi regularmente ensaiada usando-se células carenciadas as quais eram obtidas segundo o protocolo descrito em Métodos (item 17). Curvas de dose para soro com cêlulas 3T3 e Y-l são apresentadas nas figs. 6 e 7 .

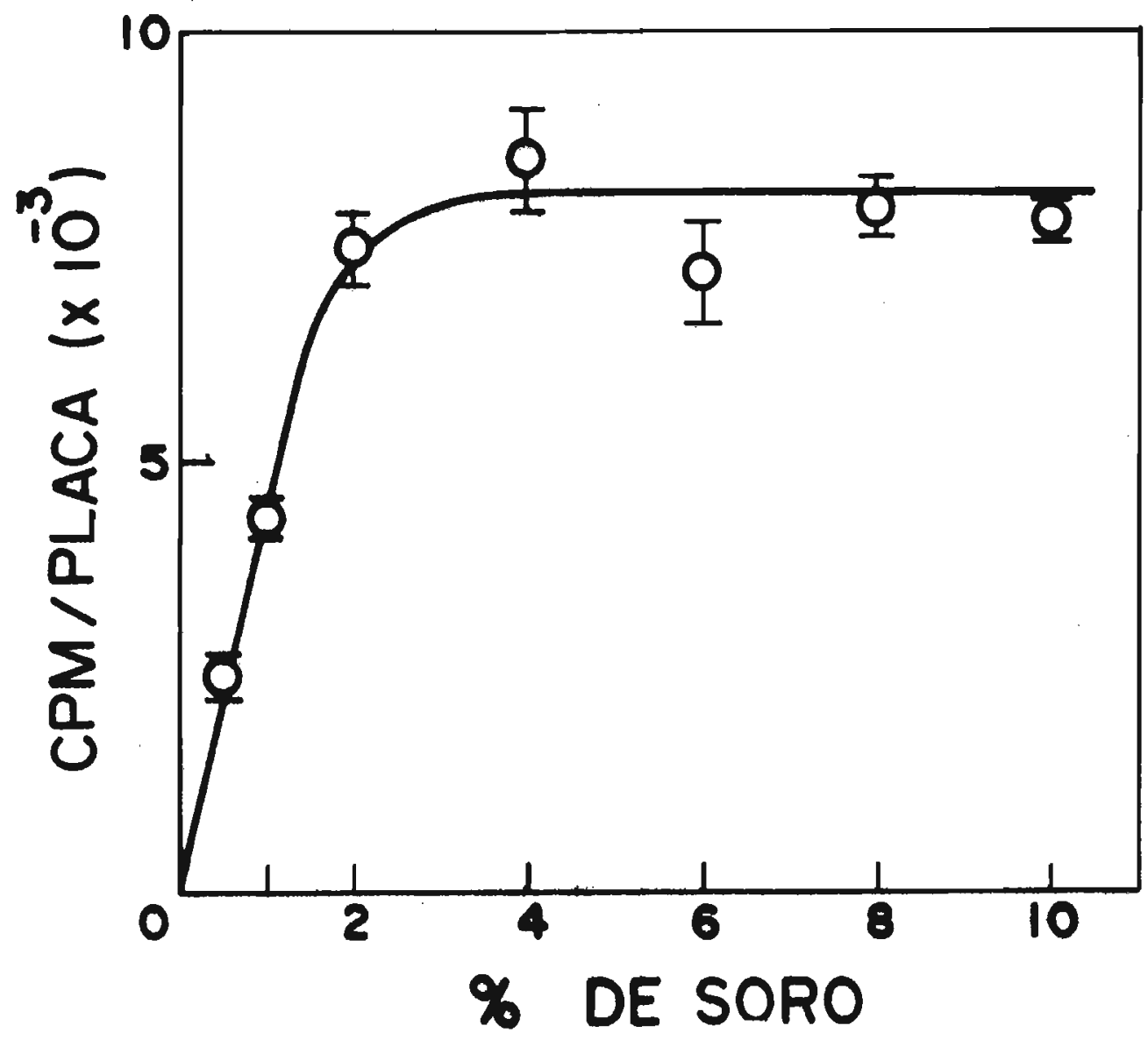

F1g. 6 - Curva de dose de soro (FCS) para células 3r3. At1vidade estimulatória da sintese de DNA, conforme descrito em Mêtodos. 


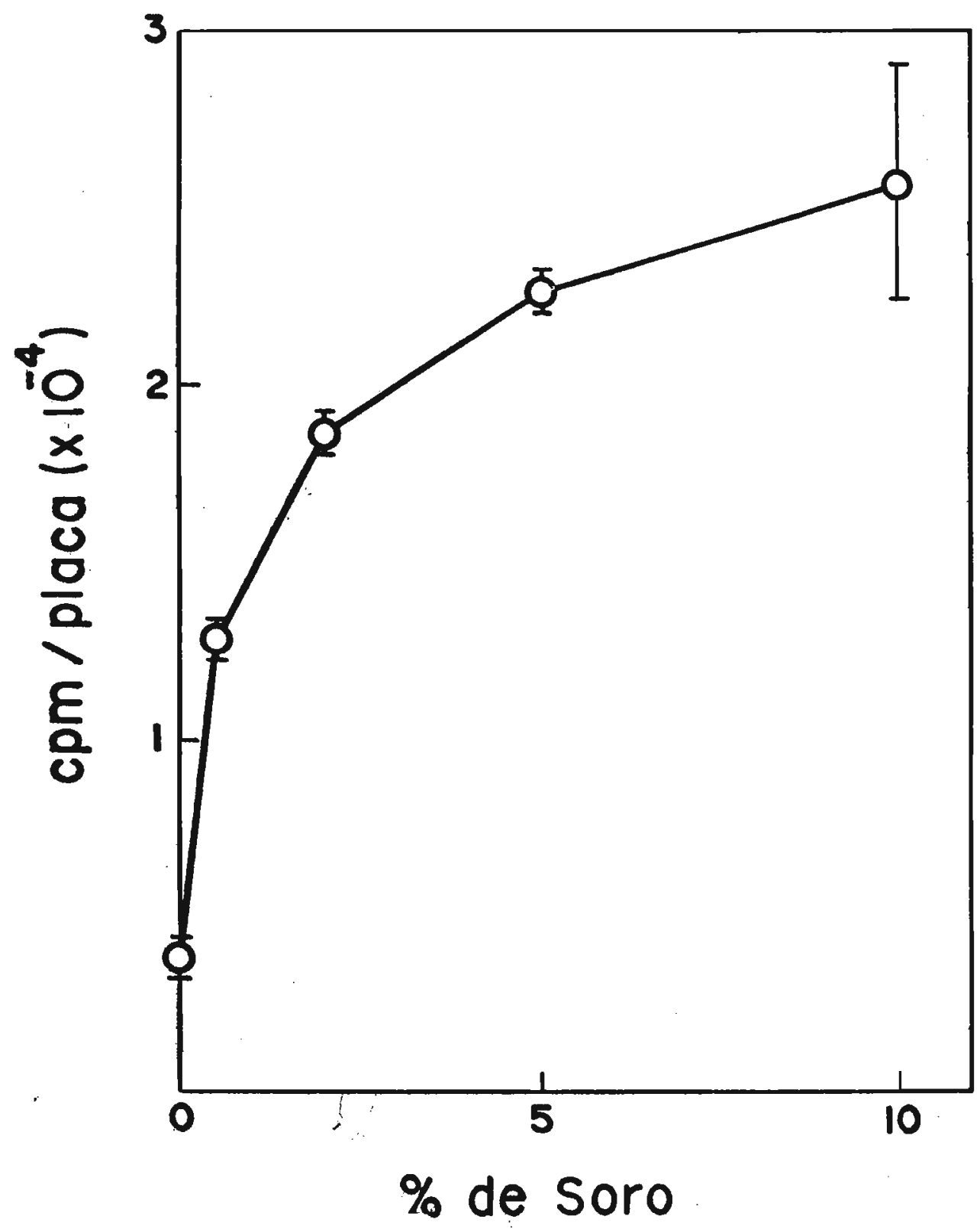

Fig. 7 - Curva de dose de soro (FCS) para células Y-1. Ativida estimulatória da sintese de DNA, conforme descrito em Métodos.

Note-se que o nível de síntese de DNA é proporcional à concen tração de soro atē atingir um"plateau". Os diferentes nívels de resposta são devidos à diferentes proporções de células que iniciam a fase s, conforme fol verificado por autorradiografia. Para a atividade do soro contribuem hormônios clássicos e fatores de crescimento, cuja identificação ainda não foi feita, 
porēm admite-se que sejam de natureza hormonal. O efeito de hor mônios clássicos no crescimento de células $3 T 3$ e Y-1 serã considerado mais adiante. Quanto aos fatores de crescimento, dois foram estudados: EGF e PF. Embora não tenha sido efetivamente demonstrado que estes fatores sejam componentes do soro, seu estudo é absolutamente necessário por se constituirem em protóti pos dos postulados fatores de crescimento.

\subsection{Atividades de EGF e PF}

EGF é uma pequena proteína ácida descoberta por COHEN (1962) em glândulas salivares de camundongos, a qual tem sua es trutura quimica totalmente caracterizada mas cujo papel fisioló gico é ainda obscuro.

Recentemente (ARMELIN, 1973) fol pela primeira vez demons trado que EGF è ativo na estimulação de fibroblastos. A fig.8a mostra uma curva de dose para EGF na estimulação de células 3T3 (as células Y-I não respondem a este fator). As ativida des de EGF e PF, em concentrações saturantes, sobre cēlulas 3T3, è somatörla (flg. 8b) sugerindo que estes fatores agem por meca nismos independentes.

Ao contrăr1o de EGF, PF estā alnda quimicamente mal caraç ter1zado. o fator (ou fatores) de pitultärla ut1l1zado nesta tese fol preparado à partir de hipófises bovinas. Extratos de pitultárla foram obtidos e fractonados conforme descrito no Item 15 de Mêtodos. Atıvidade estimulatória da sintese de DNA fol ensalada para as alversas fraçōes obtidas, 1nclusive a preparação flnal chamada PF. Curvas de dose das diversas frações, 


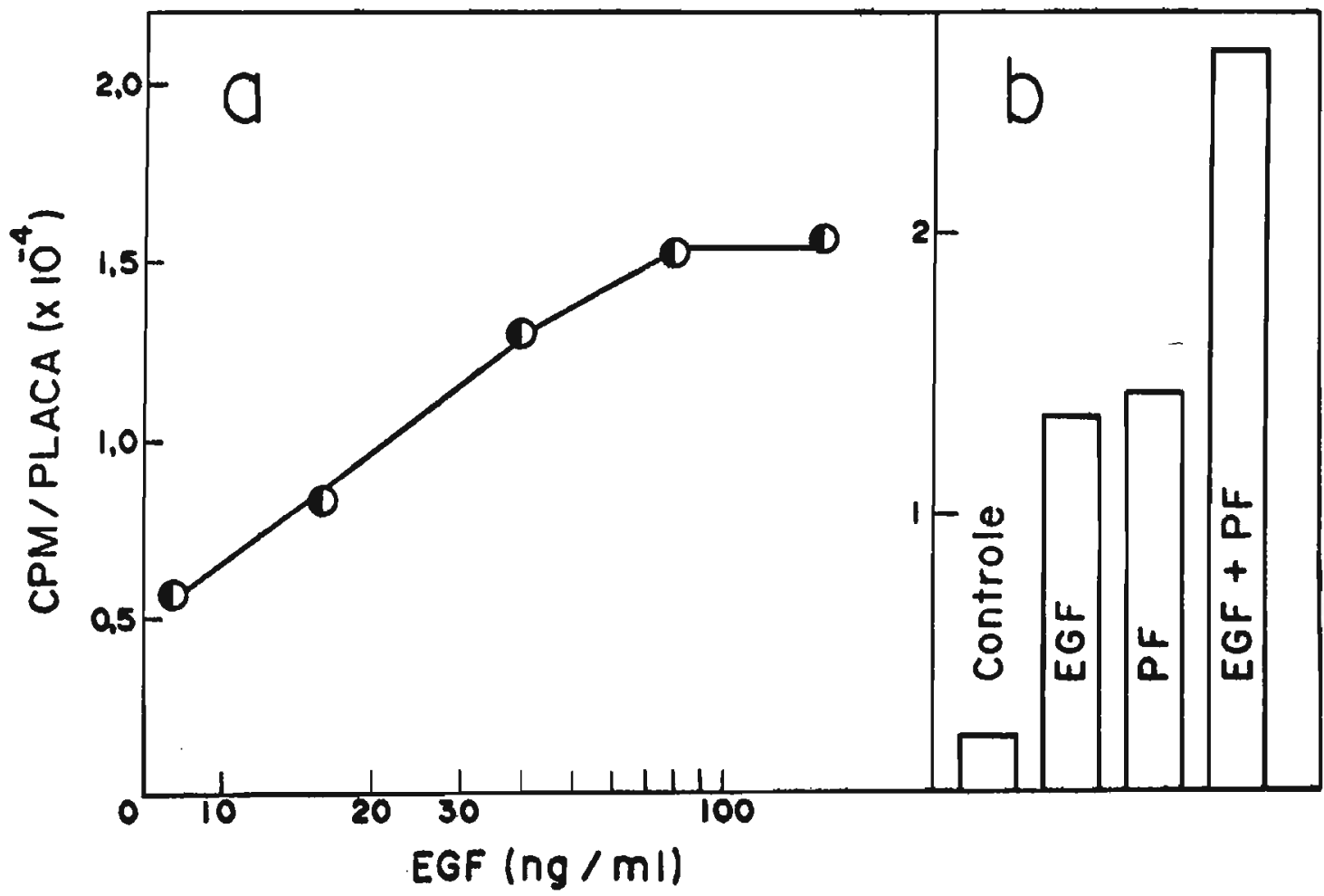

Fig. 8 - Curva de dose de EGF para células 3T3. Atividade es timulatōria da síntese de DNA, conforme descrito em Métodos.

ensaiadas com células $3 T 3$ e $Y-1$, são apresentadas nas figs. 9 e 10 respectivamente. $P F$ mostrou-se mais ativo que a preparação de NIH-LH-B8, mais ativo que o extrato cru e, além disso, não contēm inibidores da síntese de DNA para estas células. Oụ tras preparações de PF apresentaram comportamento semelhante com pequenas diferenças na atividade especifica.

Alguns autores (BURGER, 1970; SEFTON \& RUBIN, 1970) apre sentaram resultados indicando que proteases estimulam sintese de DNA e divisão celular em fibroblastos de embrião de galinha. Por outro lado è sabido que proteases podem contaminar prepara ções de hormônios proteicos da pituitária (ELLIS, 1958). Em 


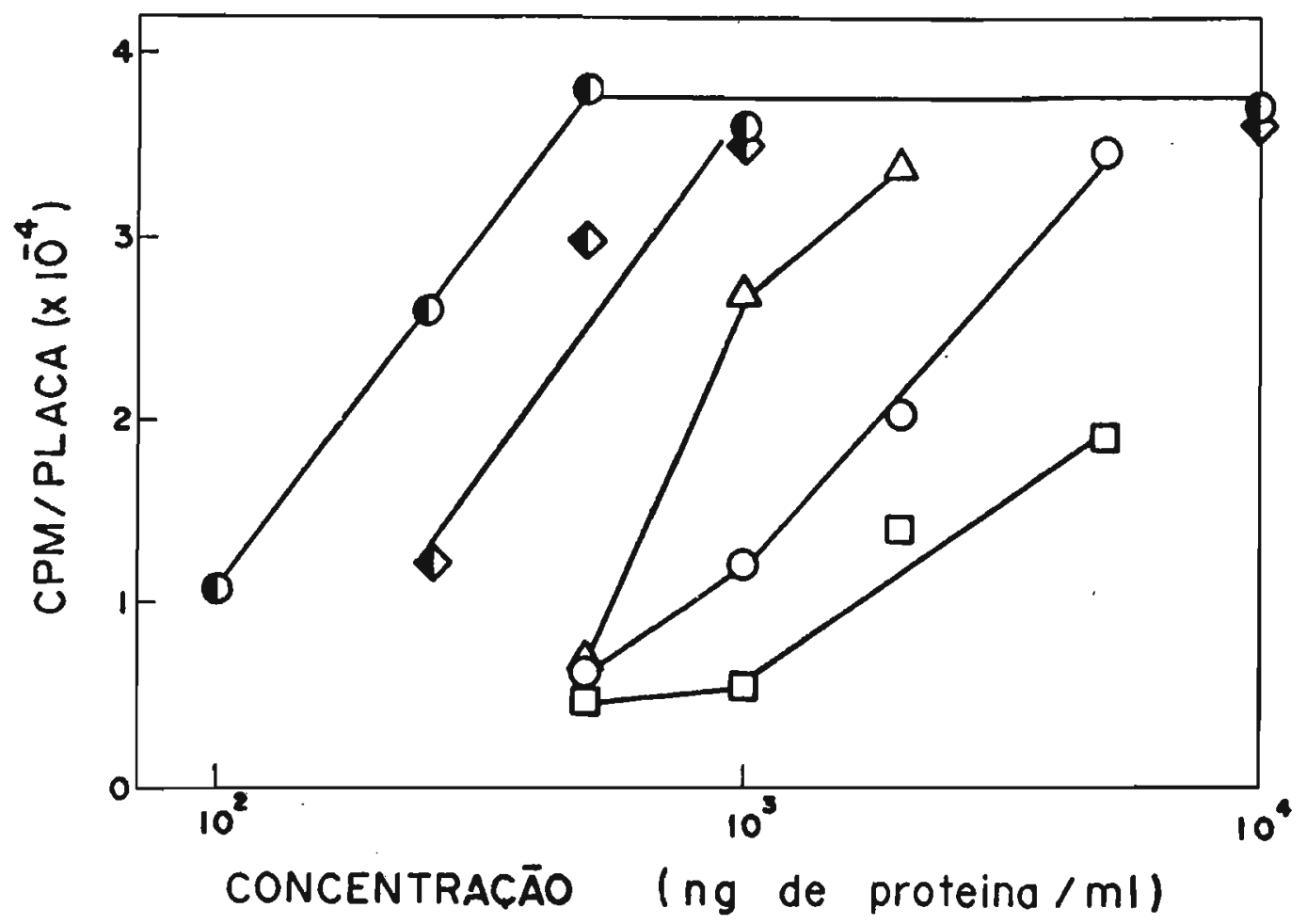

Fig. 9 - Curvas de dose das frações obtidas de glândulas pitui tárias, para células 3T3. Atividade estimulatória da síntese de DNA, conforme descrito em Métodos. O-o extrato cru; $\square-\square$ precipitado de sulfato de amônio 55\%; $\Delta-\Delta$ precipitado de sulfato de amônio $1008 ; \diamond-\triangle$ NIH-LH-B8; $\longrightarrow$ PF.

face disso foi necessārio verificar se a atividade estimulatória da síntese de DNA exibida por PF não era devida a protea ses presentes na preparação. Esta possibilidade fol testada da seguinte maneira: primeiro, ensaios de atividade proteoli t1ca foram feitos em preparações de PF e, segundo, tripsina e trombina foram usadas no nosso ensalo padrão com cëlulas carencladas na tentativa de mimetizar a atividade de PF. Atividade proteãs1ca não fol detectada em preparações de PF usando azoalbumina, azocaseina e BAPNA como substratos a pH 5,$6 ; 7,0$ e 8,0 , com concentrações de PF de ate $150 \mu \mathrm{g}$ de proteína por 
ml. Além disso a atividade estimulatória de PF não se altera se for previamente tratado com PMSF (Tabela II). Verificou-se tambēm que tripsina e trombina não apresentam qualquer atividā de estimulatória da síntese de DNA em células 3 T3 e Y-1. Dados estes resultados concluimos que a atividade estimulatória de PF provavelmente não é devida a proteases.

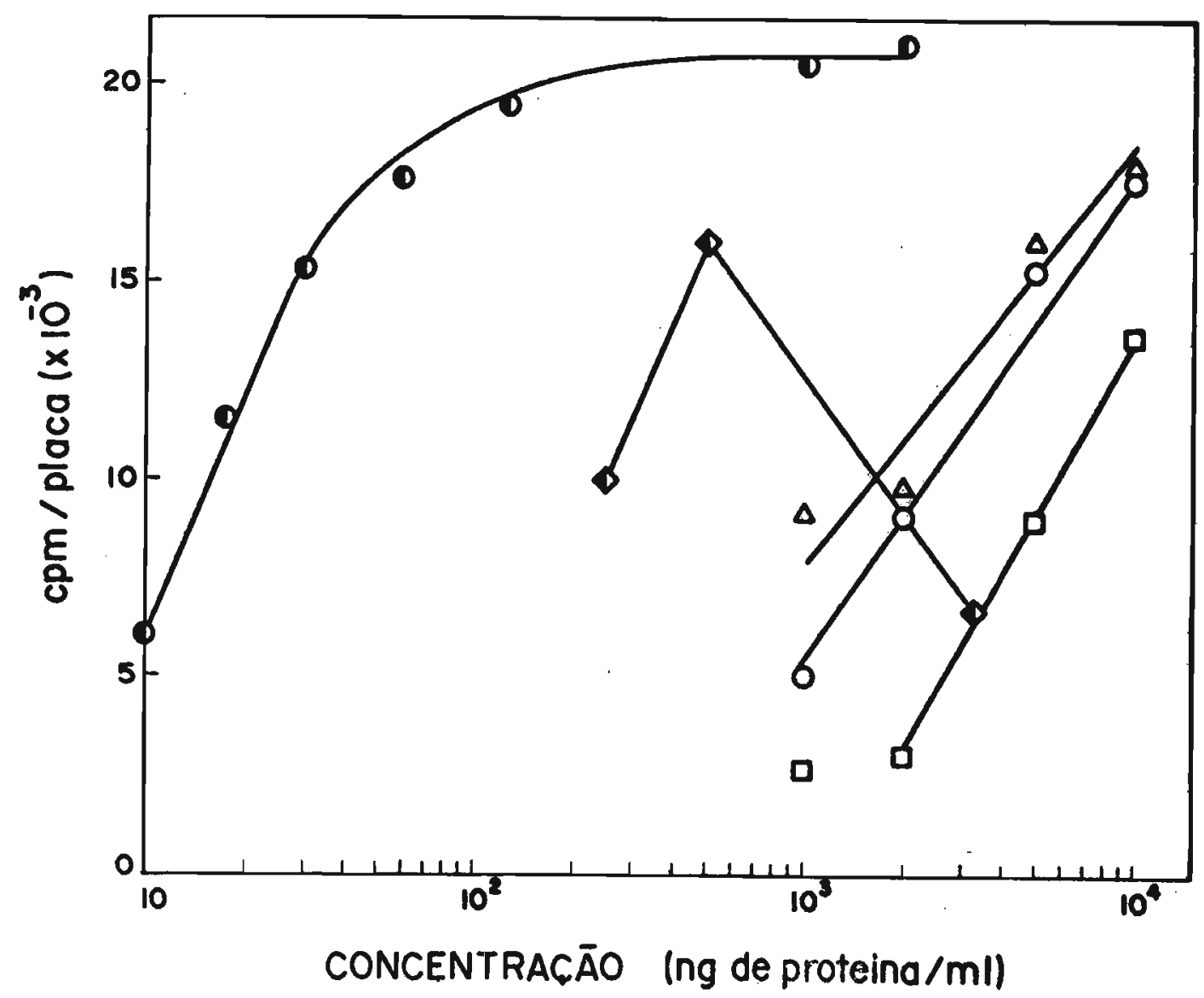

Fig. 10 - Curvas de dose das frações obtidas de glândulas pitui tārias, para células $Y-1$. Atividade estimulatória da sintese de DNA, conforme descrito em Métodos. O-O extrato cru; $\square-\square$ prectpitado de sulfato de amônio 55\%; $\Delta-\Delta$ precipitado de sulfato de amônio 1008; $\diamond-\triangle \mathrm{NIH}-\mathrm{LH}-\mathrm{B} 8 ; 0-0 \mathrm{PF}$. 
Pabela II - Efeito de PMSF sobre a atividade estimulatória de soro e PF

\begin{tabular}{c}
$\begin{array}{c}\text { Incorporação de Timidina } \\
\text { (cpm/placa) }\end{array}$ \\
\hline Células $3 \mathrm{~T} 3 \quad$ Células $\mathrm{Y}-1$
\end{tabular}

Controle $(0,28$ FCS $)$

1\% FCS dializado

1응 FCS dializado/PMSF

$1 \mu \mathrm{g} / \mathrm{ml}$ PF dializado

$1 \mu \mathrm{g} / \mathrm{ml}$ PF dializado/PMSF
8400

17700

13200

12500

13000
4000

9600

6800

10400

11400

Tratamento de soro (FCS) e PF com PMSF, conforme descrito em Mé todos.

\subsection{Resposta de Células Carenciadas}

$\mathrm{Na}$ resposta de células carenciadas à estimulação é de interesse examinar duas variáveis: a) a extensão do "lag" que precede a onda de sintese de DNA e b) a velocidade com que as células entram na fase $\mathrm{s}$ (início da replicação).

A fig. 11 mostra uma cinētica de estimulação com soro, medida em termos da porcentagem de núcleos marcados após incorporação continua de timidina ${ }^{3} \mathrm{H}$. Note-se que o "lag" é claro e igual a 14 horas. Se estes resultados forem lançados em termos de 100 - 8 de núcleos marcados (ou cêlulas que ainda não entraram em $S$ ) em função do tempo, num gräfico semilogaritmico, obtëm-se a curva da fig. 12. Este gräfıco mostra que a entrada de células em s segue uma clnêtı́a de primeira ordem. 


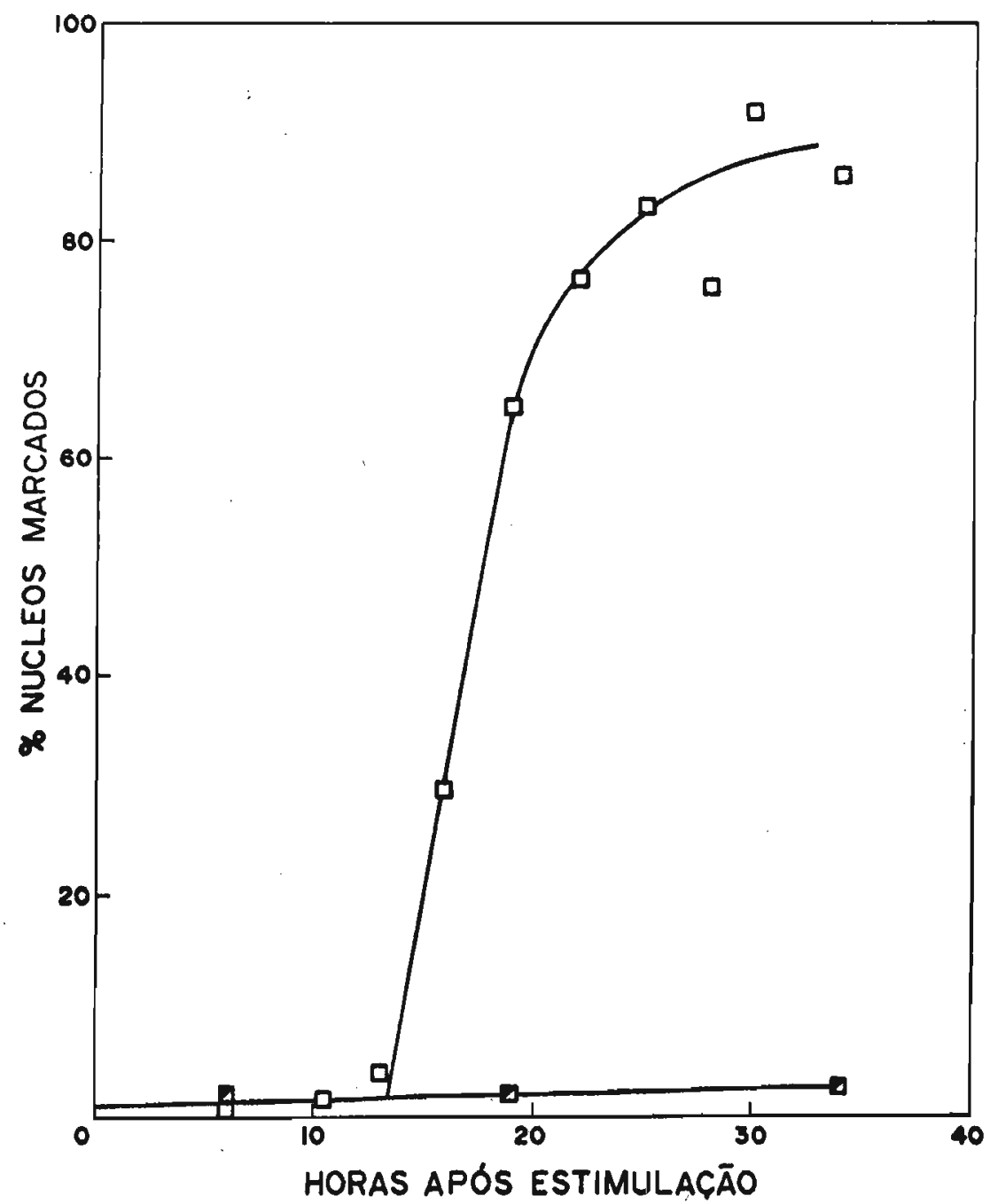

Fig. 11 - Cinética de reestimulação da síntese de DNA por soro, em fibroblastos (STI) carenciados para soro. Protocolo descrito em Métodos. $\square-\Delta$ culturas controle (nã̃o estimuladas): $\square-\square$ estimuladas com 58 FCS em $t=0$. Gráfico da ơ de núcleos marcados (células que entraram em $S$ ) em função do tempo após reestimulação; escalas lineares.

Este padrão parece ser geral sendo um ponto importante o caráter tudo ou nada da resposta celular. o "lag" é o tempo que leva para uma célula deixar o estado Go e atingir s passando pe la fase $\mathrm{Gl}^{\mathrm{C}}$ postulada na introdução. Operacionalmente pode-se referir a este "lag" simplesmente como uma fase Gl.

Podemos adiantar que na resposta das células carenciadas o "lag" que precede a sintese de DNA é constante e não depende nem do tipo e nem da concentração do estimulador (soro, 
hormônio ou fator de crescimento). Já a constante de velocidade da entrada de células em $\mathrm{S}$ aumenta com a concentração do estimulador.

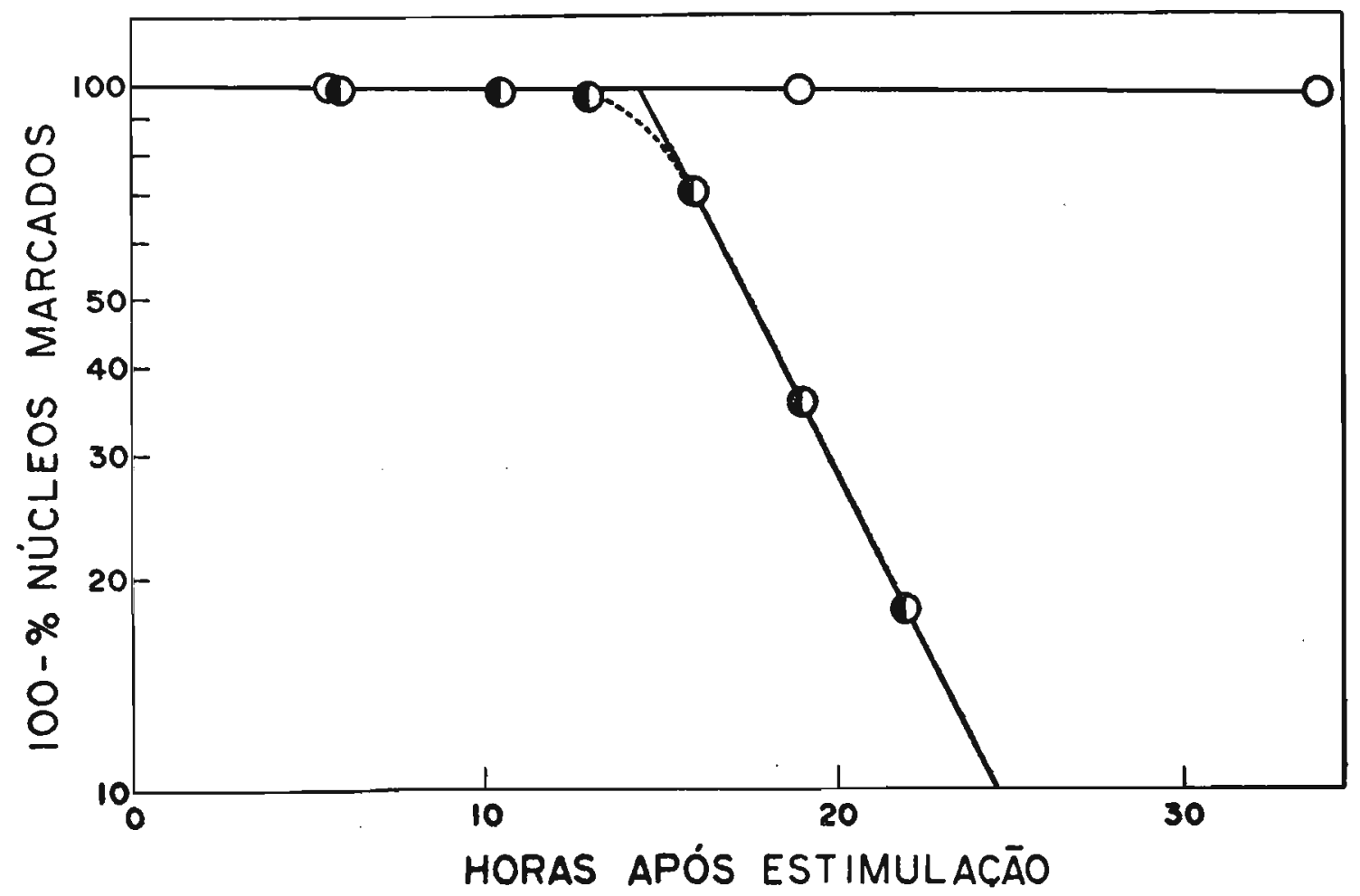

Fig. 12 - Cinētica de reestimulação da sintese de DNA por soro, em fibroblastos (STI) carenciados para soro. 0-0 culturas controle (não estimuladas); $O-O$ estimuladas com 5\% FSC em $t=0$. Neste gráfico semilogaritmico foram lançados os valores de (100 - o de núcleos marcados) os quais correspondem a células que ainda não entraram em $S$, em função do tempo.

2. ANÁLISE DO COMPORTAMENTO DE CELULAS 3T3

2.1. Parâmetros de Crescimento

Os parâmetros de crescimento da linhagem 3T3 encontram-se resumidos na Tabela III. Para comparação foram colocados tam bëm nesta tabela, dados referentes à linhagem SV3T3 e a variante STl derivada de células $3 T 3$ e discutida mais adiante: Note-se 
$-52-$

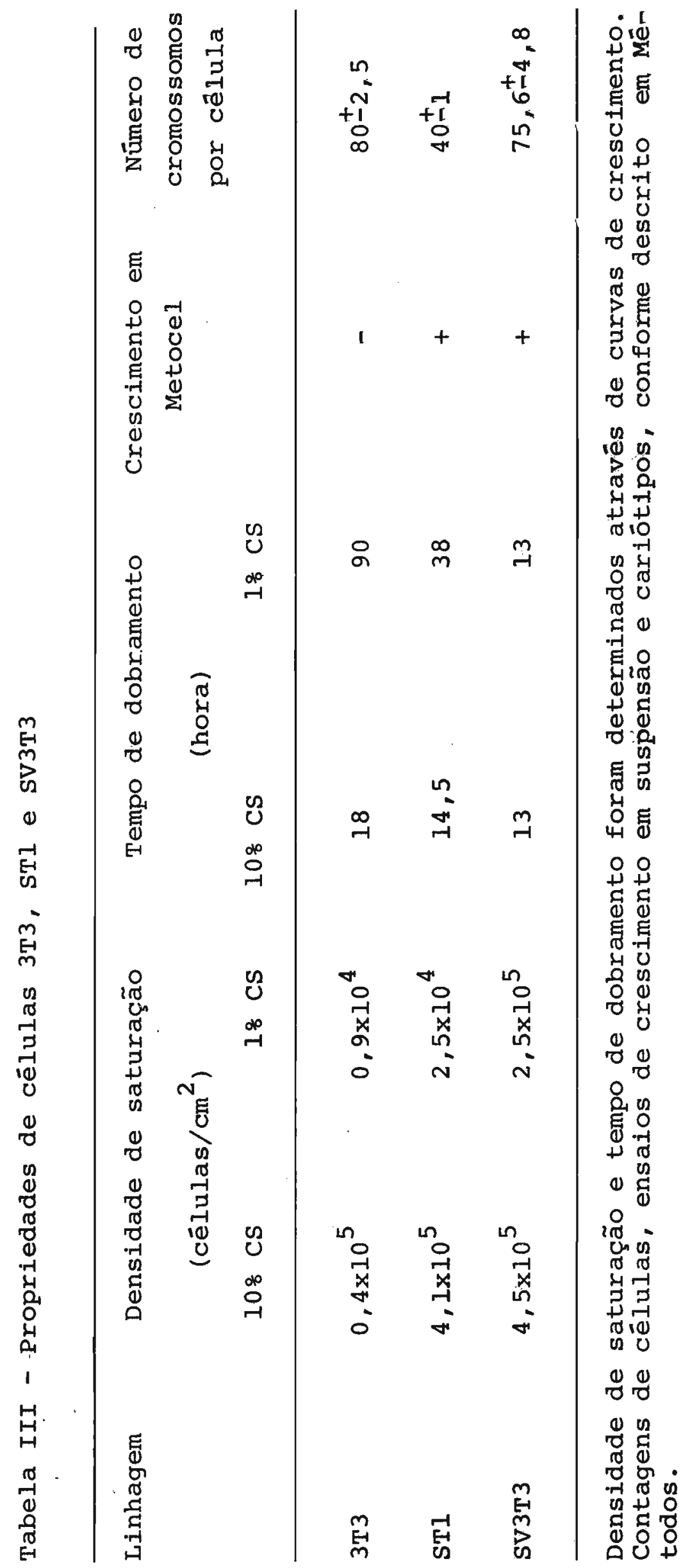


que a linhagem 3T3 praticamente não cresce em baixas concentrações de soro (1.8), apresenta densidade de saturação em $10 \%$ de soro da ordem de 10 vezes menor que a linhagem $3 \mathrm{~T} 3$ transforma da por vỉrus SV40. Além disso enquanto células sV3T3 crescem em suspensão de metilcelulose formando colônias macroscópicas, células 3т3 não crescem neste meio, chegando, no māximo a formar microcolônias de 6 a 8 células.

E interessante lembrar que estes parâmetros (dependência de soro, densidade de saturação e crescimento em suspensão) têm sido classicamente usados para distinguir os fenótipos "nor mal" e"transformado". As células $3 \mathrm{~T} 3$ e sV3T3 tipificam, respec tivamente, cēlulas "normais" e "transformadas".

2.2. Efeito de Soro, Hormônios e Fatores de Crescimento

O efeito de diferentes concentrações de soro sobre a síntese de DNA de células $3 \mathrm{~T} 3$ em repouso pode ser visto na fig. 6. "Plateau" è atingido à concentrações entre 2 e 48 .

A atividade estimulatōria da sintese de DNA de hormô nios e fatores de crescimento fol medida e os resultados estão sumarizados na tabela IV. Esta tabela indica que a modulação do crescimento de cêlulas $3 T 3$ è complexa, envolvendo um nümero alnda Indefinido de reguladores extracelulares do tipo endócrino. O efelto destes reguladores è variado podendo combina ções deles levar a efeitos somatórios ou sinergisticos. Cabe destacar aqui alguns pontos. Hidrocortisona tem pequeno efelto estimulatório em concentrações f1siolöglcas; 1nsulina só tem efelto efelto estimulatōrio signiflcat1vo em concentrações não 
Tabela IV - Atividade estimulatória de diversos fatores sobre a sintese de DNA de células $3 \mathrm{~T} 3$ e STl carenciadas para soro

\begin{tabular}{|c|c|c|c|}
\hline Fatores de crescimento, & Células & & ST1 \\
\hline hormônios ou soro & $3 \mathrm{~T} 3$ & $-\mathrm{H}$ & $+\mathrm{H}$ \\
\hline EGF & 38 & 0 & 0 \\
\hline Insulina (I) & $65^{a} ; 4^{b}$ & $15^{\mathrm{a}}$ & $0^{a}$ \\
\hline Hidrocortisona (H) & 15 & - & - \\
\hline PF & 44 & 0 & 0 \\
\hline Somatomedina B & 1,3 & 0 & 0 \\
\hline Somatomedina C & 0,9 & 0 & 0 \\
\hline $\mathrm{PGF}_{2 \alpha}$ & 5 & 0 & 0 \\
\hline Albumina (BSA) & 105 & 65 & 24 \\
\hline $\mathrm{PF}+\mathrm{H}$ & 85 & - & - \\
\hline $\mathrm{EGF}+\mathrm{H}$ & 55 & - & - \\
\hline$P F+E G F$ & 70 & 0 & 0 \\
\hline$P F+I$ & $105^{\mathrm{a}}$ & 11 & 0 \\
\hline $\mathrm{EGF}+\mathrm{I}$ & $103^{a}$ & NT & NT \\
\hline $\mathrm{BSA}+\mathrm{I}$ & 106 & $70^{\mathrm{a}}$ & $96^{a}$ \\
\hline $\mathrm{PGF}_{2 \alpha}+I$ & $25^{b}$ & $\mathrm{NT}$ & $0^{a}$ \\
\hline CS & 100 & 100 & 100 \\
\hline FCS & 110 & 108 & 178 \\
\hline
\end{tabular}

Todos os fatores foram usados em concentrações saturantes: EGF : $100 \mathrm{ng} / \mathrm{ml}$; Insulina: a 2,5 $\mathrm{gg} / \mathrm{ml}$ e b $50 \mathrm{ng} / \mathrm{ml}$; hidrocortisona: $300 \mathrm{ng} / \mathrm{ml}$; $\mathrm{PF}: 1 \mu \mathrm{g} / \mathrm{ml}$; Somatomedinā B: $1 \mu \mathrm{g} / \mathrm{ml}$; Somatomedina C: $30 \mathrm{ng} / \mathrm{ml}$; $\mathrm{PGF}$ : $500 \mathrm{ng} / \mathrm{ml}$; $\mathrm{BSA}$ (albumina de soro bovino): 10 $\mathrm{mg} / \mathrm{ml}$; CS (sorg de vitelo): 5\%; FCS (soro fetal bovino): 5\%. Os valores da tabela representam a média de 3 experimentos. As ati vidades foram normalizadas ém relação à CS. NT: não testado. 
fisiológicas $(2,5 \mu \mathrm{g} / \mathrm{ml})$. No entanto ambos, hidrocortisona e insulina, em concentrações fisiológicas, têm efeito sinergístico quando adicionadas junto com PF. Como jä mencionado (fig. 8b) EGF e PF têm efeitos somatörios. Somatomedinas B e C e tambēm $\mathrm{PGF}_{2 \alpha}$ têm atividade marginal ou não têm atividade. Já a combinação de $\mathrm{PGF}_{2 \alpha}$ com concentrações fisiológicas de insulina mostra atividade significativa. Preparações comerciais de albumina de soro bovino podem apresentar altas atividades (de 5 lotes testados, 2 tiveram alta atividade, 2 tiveram baixa atividade e 1 não teve atividade). Estas atividades são devidas a fatores contaminantes da albumina de dificil separação. Preparações de albumina de ovo de galinha são isentas de atividade.

2.3. Efeito da Densidade da População Sobre a Resposta Celular à Reestimulação da Sîntese de DNA

O efeito da densidade da população sobre o crescimento celular em culturas de fibroblastos foi bastante estudada no passado. A rigor antes da descoberta da ação de hormô nios e fatores de crescimento sobre fibroblastos, o efelto de densidade era o únıco fenômeno considerado digno de estudo no crescimento destas culturas. A literatura è vasta, confusa e frequentemente controversa, dal a situação polêmica em que se encontrou o fenômeno conhec1do como 1nibição de contacto. Como consequêncla disso o efelto da densidade da população sobre a estimulação da resposta celular é alnda sujelta a dúvidas. 
Em nosso ensaio padrão de atividade as culturas são esparsas $\left(1,0-1,5 \times 10^{5}\right.$ células por placa de $6 \mathrm{~cm}$ de diâme tro). Nestas circunstâncias as células estão distribuídas homogeneamente pela superficie da placa, aparecendo isoladas ou em grupos de no máximo quatro células. Com esta distribuição a resposta das células à estimulação é completamente ao acaso: os autorradiogramas mostram que o indice de marcação com timidina ${ }^{3} \mathrm{H}$ è homogêneo e independente da área considerada. Es tes resultados mudam quando as culturas começam a ficar confluentes sendo agora critico o efeito de contiguldade. Este fato é claramente demonstrado por experiências do seguinte tipo: 200 cēlulas são semeadas em placa de $6 \mathrm{~cm}$ de diâmetro; permite-se o cresclmento de colônias atē atingirem o tamanho médio de 1000 células por colônta. Neste ponto o número de células por placa ê igual ao usado no ensaio padrão de ativida de. Agora, entretanto, as células estão agrupadas em colônias grandes as quais apresentam dois tipos de células quanto à localização: células da periferia (não totalmente circundadas por outras) e células do centro da colônia (totalmente circundadas por células vizinhas). Uma vez obtidas as colônias procedeu-se ao ensaio de atividade de soro e fatores de crescimento por autorradiografia. Os resultados mostraram que as cēlulas da periferła da colônia apresentam porcentagens crescentes de núcleos marcados com concentrações crescentes de soro até que, em concentrações saturantes de soro a marcação torna-se homogê nea (1008 das células apresentando núcleos marcados). A extensão do halo de núcleos marcados é também proporcional à con centração de $\mathrm{PF}$ e, para uma dada concentração de PF, o halo ẽ 

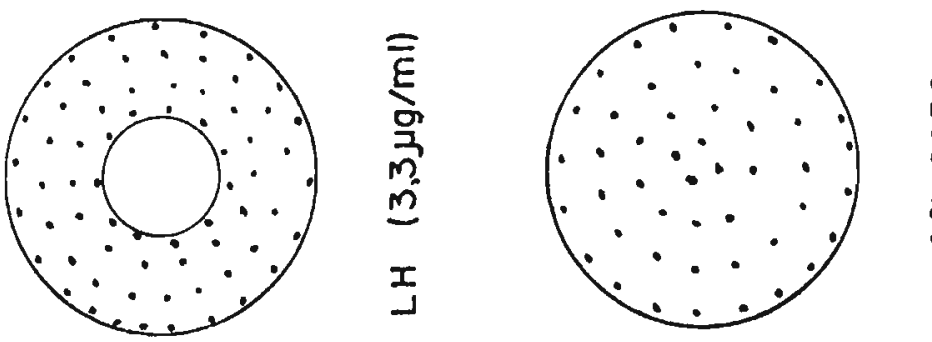

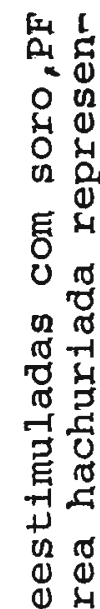
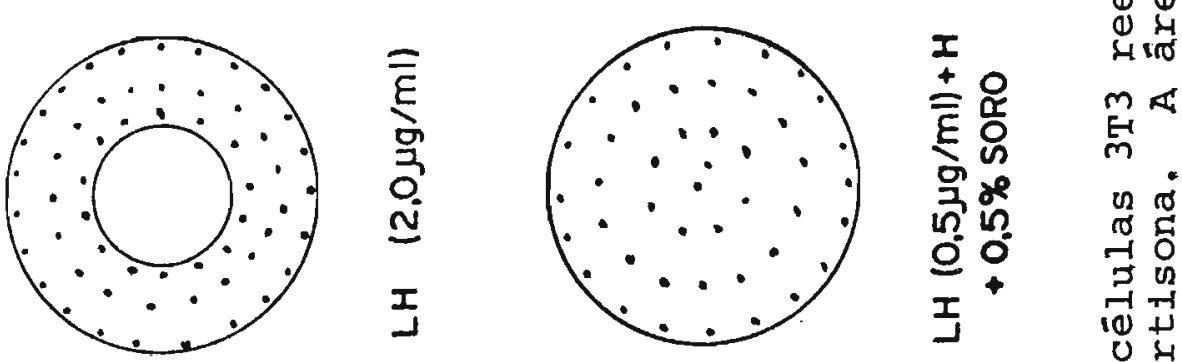

立品 जิ

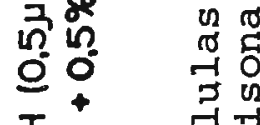
I + 它正
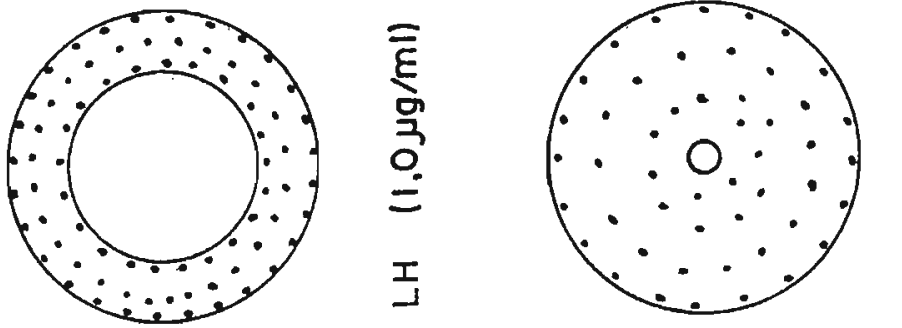

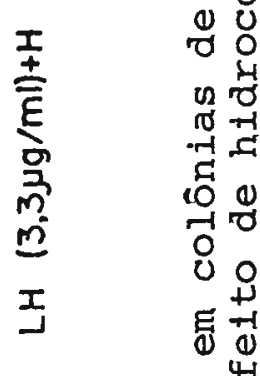
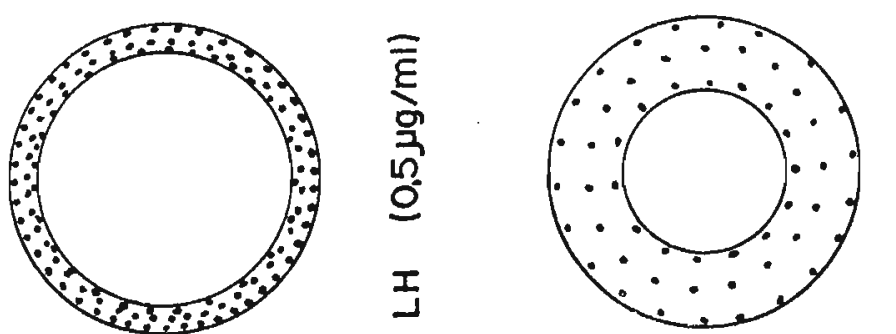

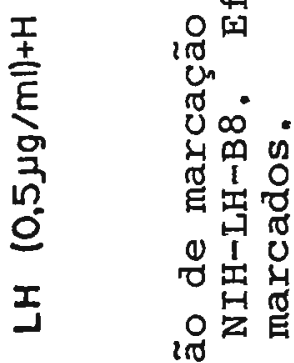
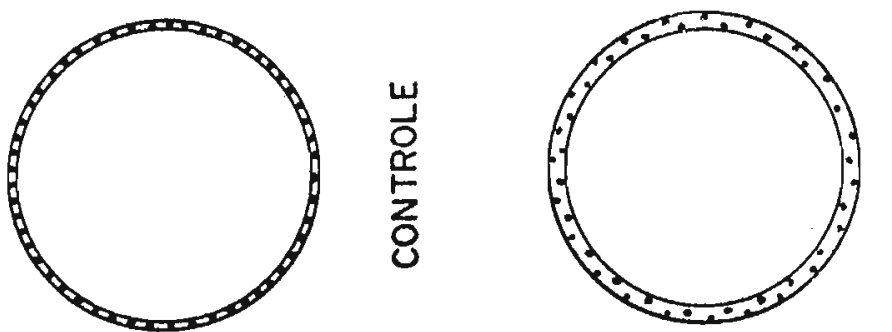

प요 (

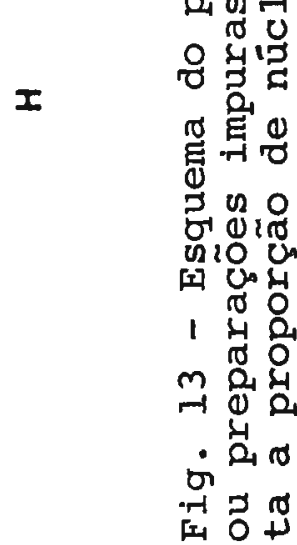


Fig. 14 - Fotomicrografias ilustrando o padrão de marcação de colônias de células 3T3 reestimuladas com soro, PF ou NIH-LH-B8. Efeito de hidrocortisona. a) Controle (não estimulado); b) es. timuladas com concentrações subótimas de soro, PF ou NIH-LH-B⿱一; ; c) concentrações subótimas de soro, PF ou NIH-LH-B8 + hidrocor tisona ( $100 \mathrm{ng} / \mathrm{ml}) ;$ d) concentração saturante de soro (5\% FCS); o mesmo aspecto é obtido com concentrações subótimas de PF lou $\mathrm{NIH}-\mathrm{LH}-\mathrm{B} 8)+$ hidrocortisona $+0,58$ FCS. Aumento: 50X. 


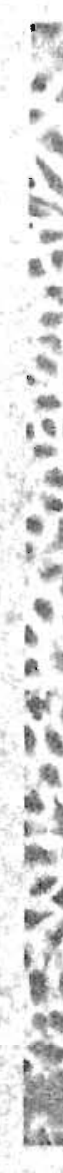

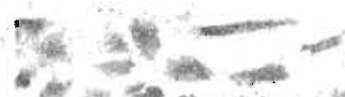

$7 x$ th th tow

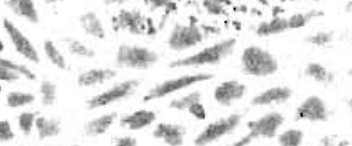

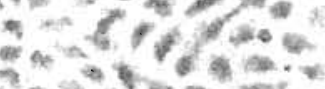

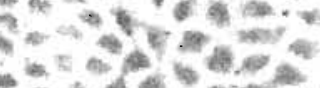

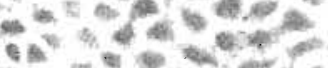

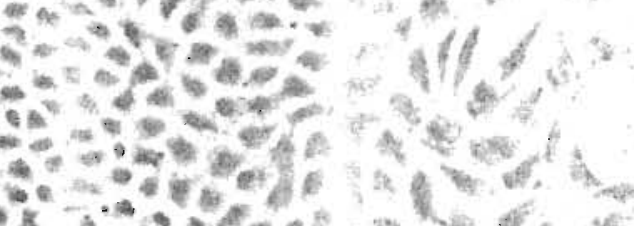

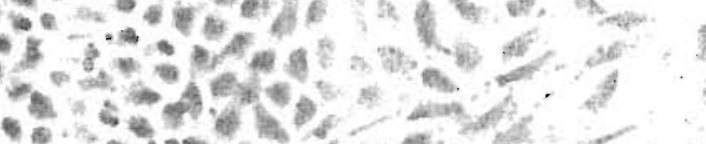

is a 20 e

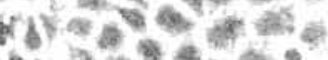

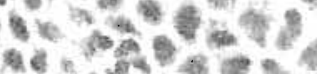

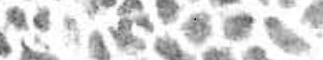

4 - whe

$* 0$ o

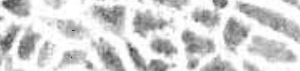

8. 3 .

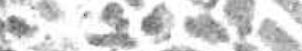

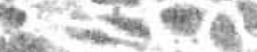

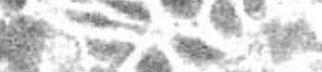
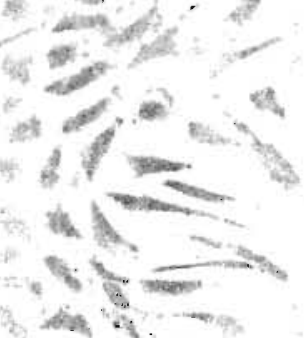

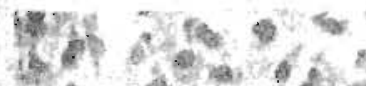

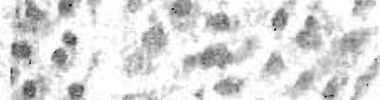

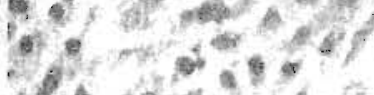

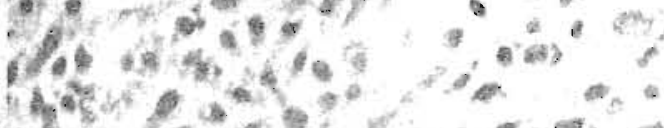

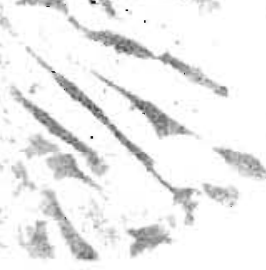

i.

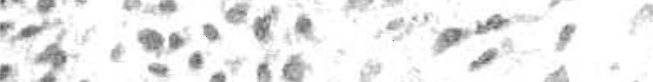

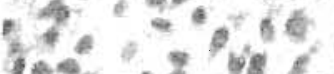

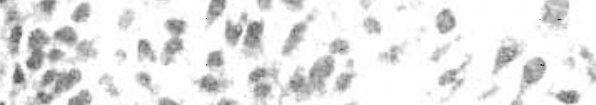

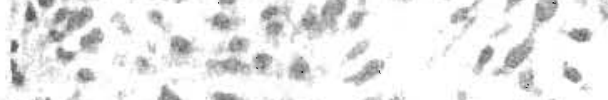

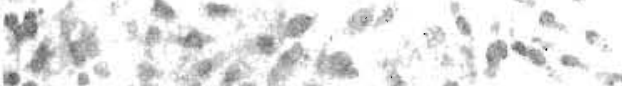

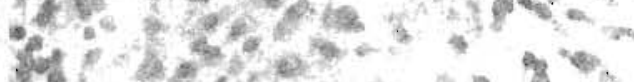

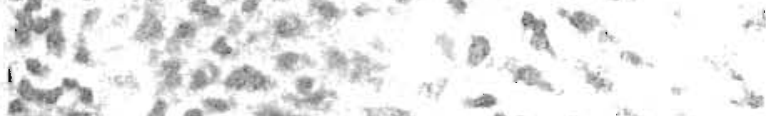

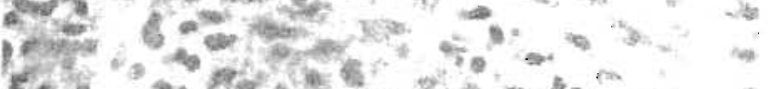

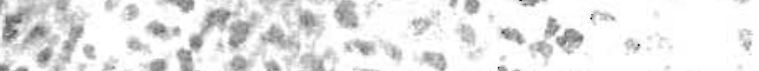

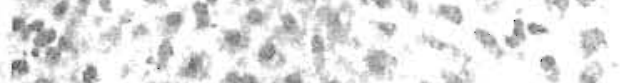

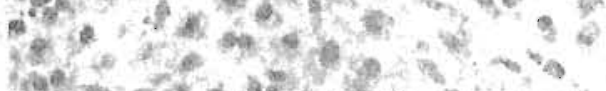

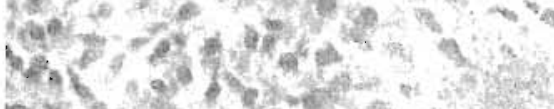

Q

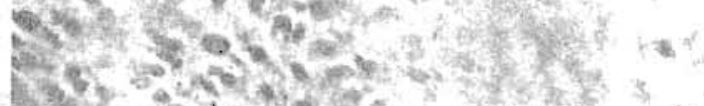

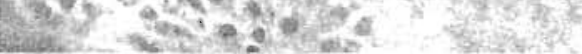

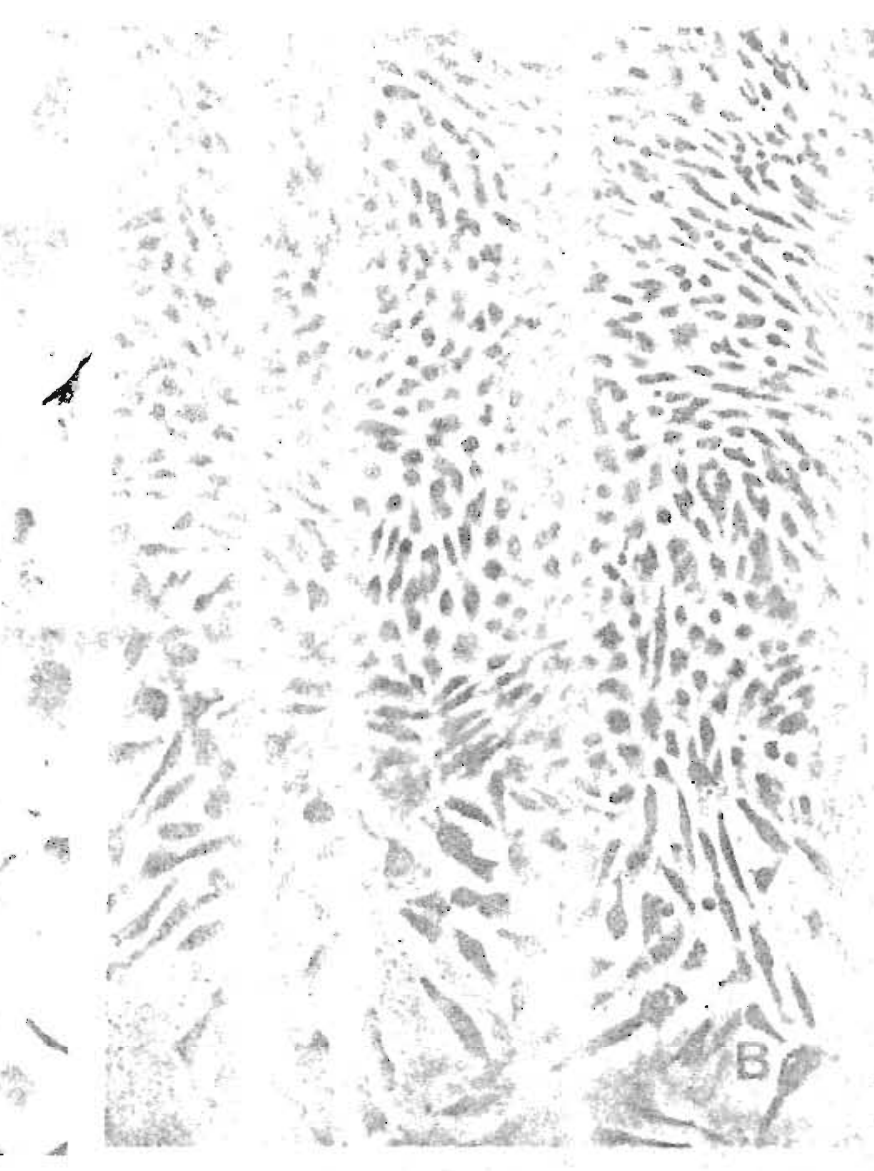

metio

ing

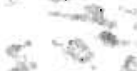

$-6 x^{2}$

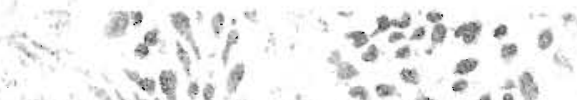

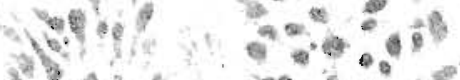

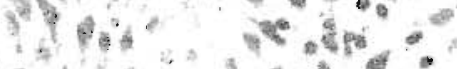

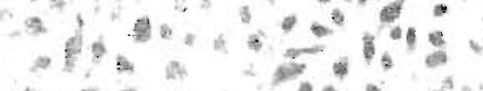

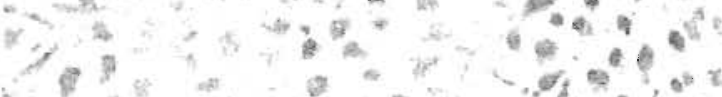

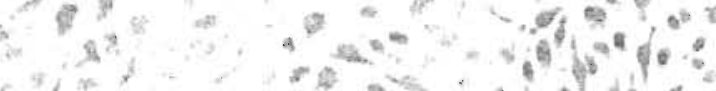

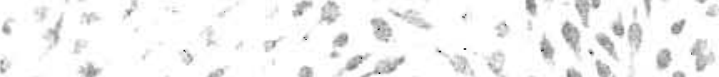

Fis

Dow

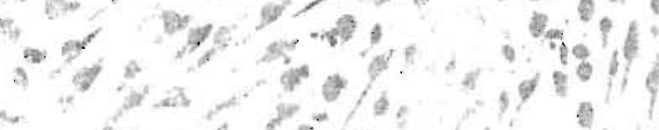

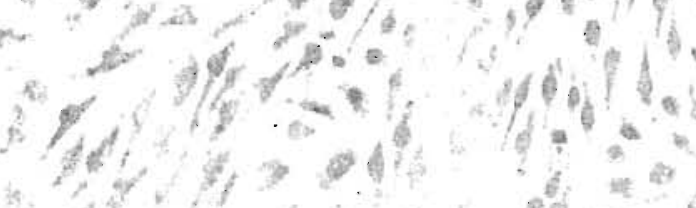

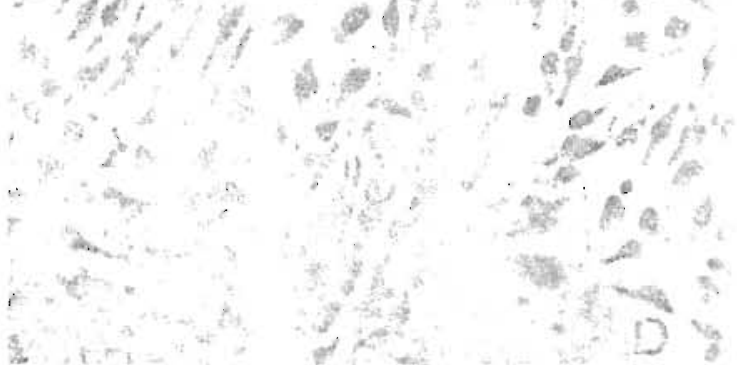


maior quando em presença de hidrocortisona (efeito sinergístico). Estes resultados, que encontram-se esquematizados na fig. 13 e ilustrados na fig. 14, mostram, portanto, que a capacidade de resposta das células aos fatores de crescimento diminuï-se à medida que vão ficando circundadas pọ outras. Esta parece ser uma propriedade geral de fibroblastos normais, sendo ausente ou muito menos acentuada em fibroblastos transforma dos. Não obstante a diminuição da magnitude da resposta, célụ las confluentes mostram a mesma cinētica de resposta quando es timuladas (ver seção seguinte).

\subsection{Cinética da Entrada de Células em S Após Estimulação}

Estudos cinëticos foram feitos a fim de medir o "lag" que ocorre entre as reestimulação por soro ou fatores de crescimento e a sintese de DNA (operacionalmente definido como Gl). o protocolo seguido está descrito no item 20 de Métodos. Os resultados, apresentados nas figs. 15 a e b, indicam que: a) a onda de síntese de DNA que ocorre após estimulação com soro, hormônios ou fatores de crescimento é precedida de um "lag" idêntico de 12 a 13 horas; b) o efeito aditivo de PF e insulina sobre a estimulação dada por EGF e o efeito sinergístico de hidrocortisona sobre a estimulação dada por PF (tabela IV) são devidos a um aumento na velocidade de entrada em $\mathrm{S}$ sem interferir com o tamanho do "lag"; c) o "lag" (ou Gl) é constante e independente do fator estimulatōrio. Deve-se mencionar ainda que o tamanho do "lag" independe da densidade da cultura sendo o mesmo para células confluentes ou subconfluentes. 


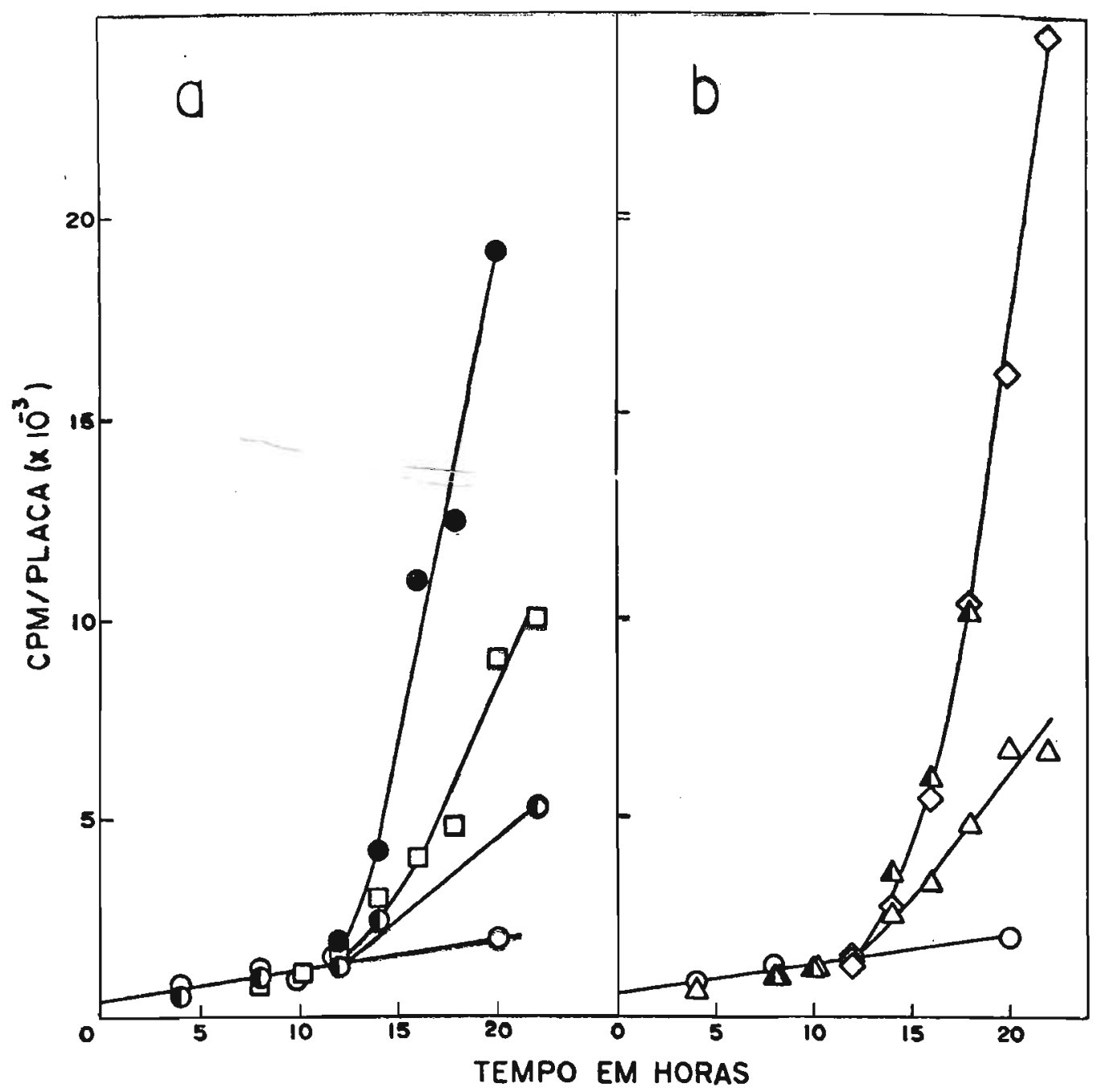

Fig. 15 - Cinētica de reestimulação da síntese de DNA por soro, hormônios e fatores de crescimento em células 3T3. 0-0 Controle (não estimuladas); ○ EGF $(0,1 \mathrm{~g} / \mathrm{ml}) ; \square-\square$ Insulina $(2,5$ $\mu \mathrm{g} / \mathrm{ml}) ; \Delta-\Delta \mathrm{PF}(1 \mu \mathrm{g} / \mathrm{ml}) ;-\operatorname{EGF}(0,1 \mu \mathrm{g} / \mathrm{ml})+\mathrm{PF}(1 \mu \mathrm{g} / \mathrm{ml})+$ Insulina $(2,5 \mu \mathrm{g} / \mathrm{ml}): \triangle-\triangle P F(1 \mu \mathrm{g} / \mathrm{ml})+$ hidrocortisona $(0,3$ $\mu \mathrm{g} / \mathrm{ml}) ; \diamond-\diamond$ soro (10\% FCS).

Interpretamos estes resultados da seguinte maneira: a) somente células que estão em Go (estado de repouso) respondem à estimulação e b) o estimulo apenas determina se a célula sai ou não de Go mas não interfere com a velocidade com que elas progri dem atē a fase $S$. Esta interpretação ẽ ainda melhor evidenclada pela experiência da flg. 16. Neste caso as células 


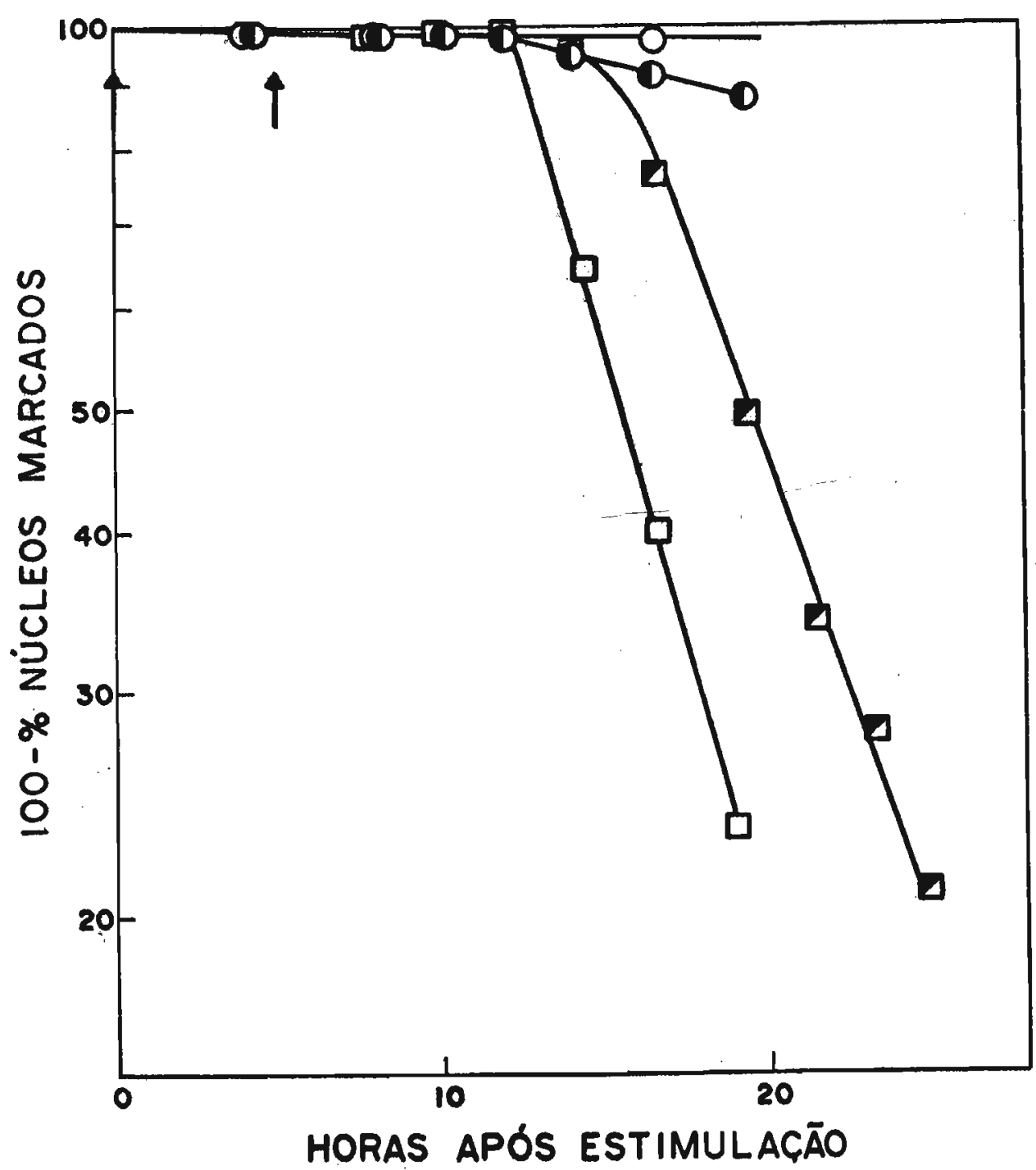

Fig. 16 - Cinétı́a da entrada em 5 de cêlulas 3T3 carencladas pa ra soro, após estimulação com hormônios e fator de crescimento. $0-0$ Controle (não estimuladas); $0-0 \mathrm{PF}$ ( $1 \mu \mathrm{g} / \mathrm{ml}$, adicionado em $t=0)$; $\square-\square$ PF $(1 \mu \mathrm{g} / \mathrm{ml}$ em $t=0)+$ hidrocortisona $(0,3$ $\mu \mathrm{g} / \mathrm{ml}$ em $t=0)+1$ insulina $(2,5 \mu \mathrm{g} / \mathrm{ml}$ em $t=0) ; \Delta-\Delta \mathrm{PF}(1 \mu \mathrm{g} /$ ml em $t=0)+$ hidrocortisona $(0,3 \mu \mathrm{g} / \mathrm{ml}$ em $t=5 \mathrm{~h})+$ insulina $(2,5 \mu \mathrm{g} / \mathrm{ml}$ em $t=5 \mathrm{~h})$.

estimuladas no tempo zero com PF ou com a combinação de PF + Insulina + hidrocortisona. Aleẻm disso um lote de culturas fol estimulado no tempo zero somente com PF e 5 horas depois insulina e hidrocortisona foram adicionadas. Como era de se esperar as células estimuladas com PF apenas ou com a combinação de hormộnos, 
em $t=0$, começaram a entrar em $\mathrm{s}$ ao mesmo tempo, somente que no primeiro caso o fluxo de entrada (cinëtica de primeira or dem) foi muịto menor. Já as culturas estimuladas com PF(t $=0$ ) e insulina + hidrocortisona $(t=5 \mathrm{~h})$. apresentaram uma curva bifãsica para entrada em S: inicialmente a velocidade de entrada foi idêntica à de PF apenas e, posteriormente (aproximadamente 5 horas depois) a velocidade passou a ser igual à de culturas estimuladas em $t=0$ com a combinação de $P F+$ insulina + hidrocortisona.

2.5. Efeitos da Diminuição da Concentração de Soro no Meio de Cultura

Conforme foi indicado pelos dados jā apresentados, a redução do soro no meio de cultura leva ao acúmulo das células no estado Go (repouso). Para células em crescimento exponencial este acümulo é progressivo e a cinética do processo foi seguida através de: a) a frequência de nưcleos marcados após pulso de timidina ${ }^{3} \mathrm{H}$ (estimativa do "pool" de células em $\mathrm{s}$ ); b) - Indice mitótico. Os resultados são apresentados nas figs. $17 \mathrm{a} e \mathrm{~b}$. A curva de frequência de núcleos marcados (fig. 17a) revelou que 4 a 5 horas após à redução do soro, o "pool" de células em s cai continuamente. O valor minimo (menor que $1 \%$ de núcleos marcados) só é atingido cerca de 20 horas após a diminuição da concentração de soro. A curva de indice mitótico (fig. 17b) mostrou uma queda brusca apōs 3 horas para manter-se, então, num patamar. Estes resultados são interpretados da seguinte maneira: a) após a redução do soro, células que estão em Gl $^{C}$ (células em Gl comprometida a sintese de DNA) 

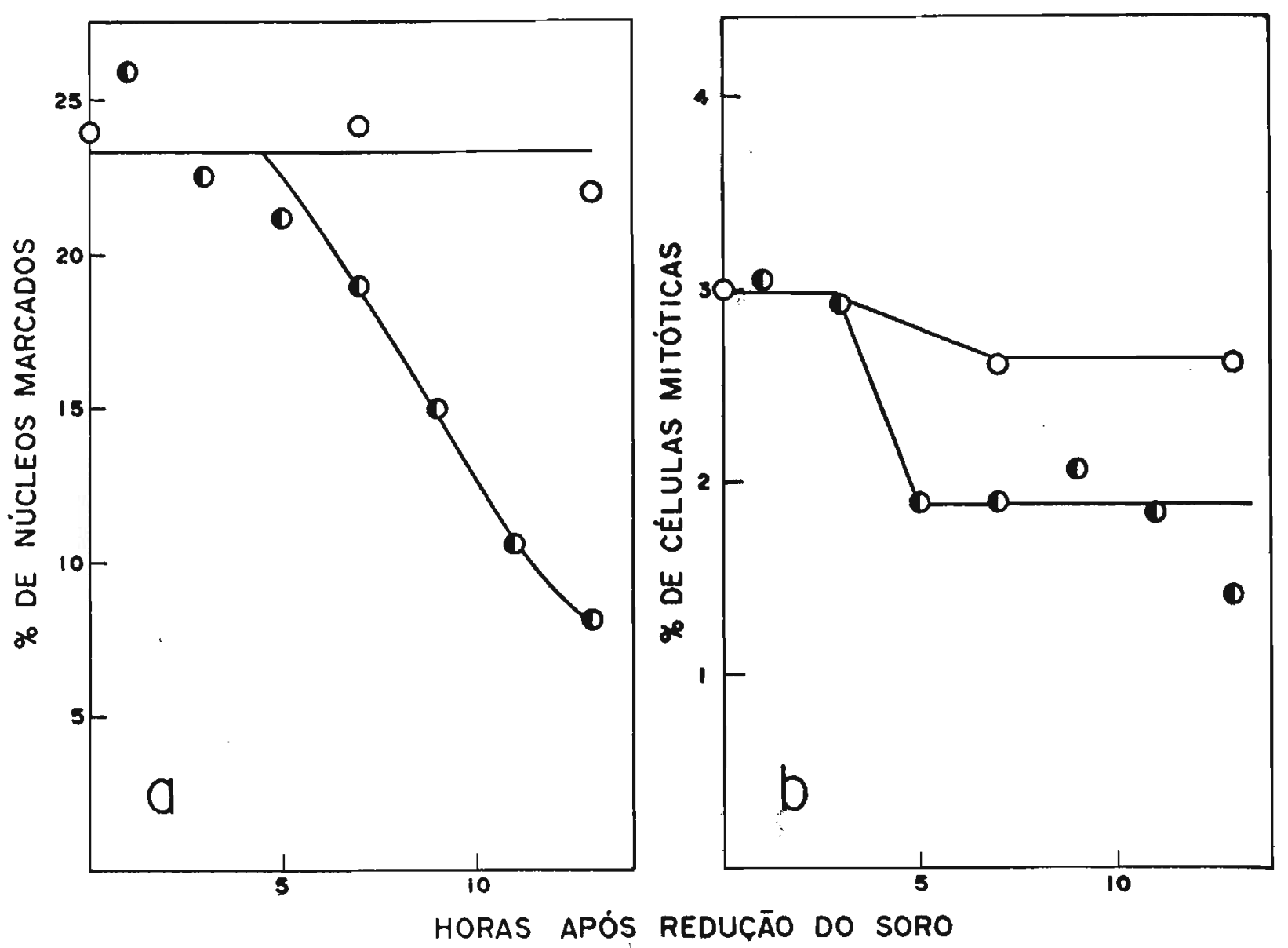

Fig. 17 - Cinética da entrada de células 3T3 no estado de repou so (Go). Pulsos de 30 minutos de timidina-3 ${ }_{\mathrm{H}}$. Detalhes do prô tocolo em Métodos. O-O Culturas mantidas em 58 de soro (FCS); -D Culturas transferidas em $t=0$ para meio contendo 0,28 FCS.

continuam entrando em $\mathrm{s}$ e da fig. 17a obtēm-se uma estimativa para $\mathrm{Gl}^{\mathrm{C}}$ de 4 a 5 horas; b) o "pool" de células em G2 flui normalmente para a mitose; c) 3 horas apōs a redução do soro o indice mitótico cai bruscamente devido a uma queda na velocidade de progressão das células através de $S$. Esta última inferên cia está de acordo com o longo tempo (20 horas) para que o indi ce de marcação atinja o seu nível mínimo, após a redução do soro, comparado com o tempo de duplicação da cultura em alto soro que-è de 16 horas. 
3. ANALISE DO COMPORTAMENTO DO MUTANTE STI DERIVADO DE CELULAS $3 \mathrm{~T} 3$

3.1. Isolamento da linhagem STl

Estudos do controle do crescimento celular poderiam ser ampliados e enormemente facilitados se pudessemos dispor de mutantes ou variantes de células $3 \mathrm{~T} 3$ com respostas diferentes a hormônios e fatores de crescimento. A busca deste tipo de vari ante levou-nos ao isolamento e caracterização da linhagem STl.

Clones isolados de culturas de células 3T3 mutagenizadas e não mutagenizadas passavam por uma triagem inicial após um teste de resposta a soro, PF e hidrocortisona (fig. 18). Alēm disso, como rotina, adotava-se também inspecionar monocamadas confluentes para a presença de focos de células empilhadas as quais correspondem a cēlulas espontaneamente transformadas. 0 plaqueamento sucessivo de uma cultura deste tipo, não mutagenizada, em meio contendo baixa concentração de soro, permitiu-nos obter uma população enriquecida em células variantes. Esta população foi clonada e reclonada (de acordo com o item 8 de Mēto dos) e os clones resultantes foram testados segundo o item 19 de Métodos. Como o comportamento dos clones variantes obti dos era idêntico, escolhemos um, que chamamos STl, e descarta mos os outros. Passamos então à caracterização do variante ST1.

3.2. Parâmetros de Crescimento

o crescimento de células STl em diferentes concentra ções de soro pode ser visto na fig. 19. A velocidade de crescimento 


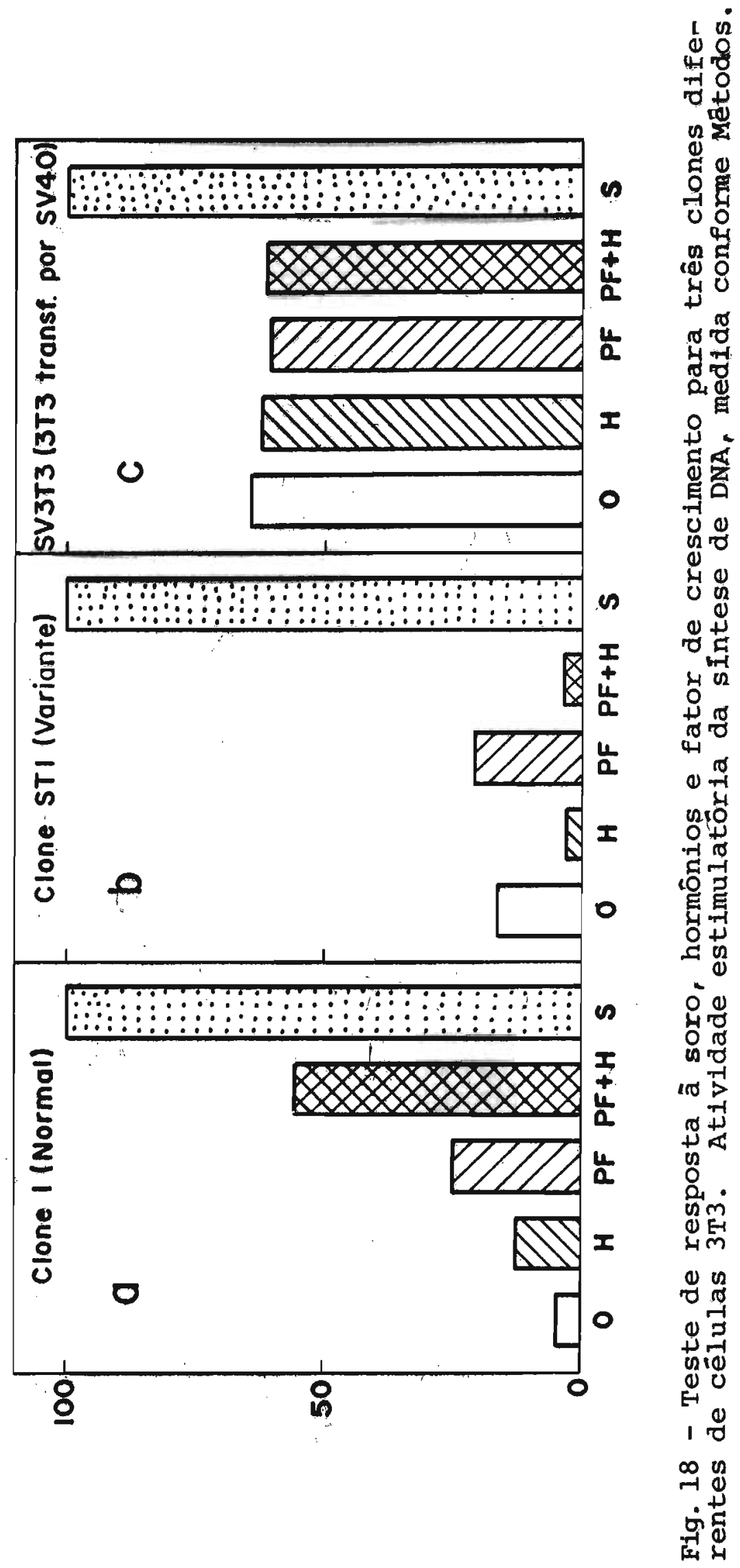




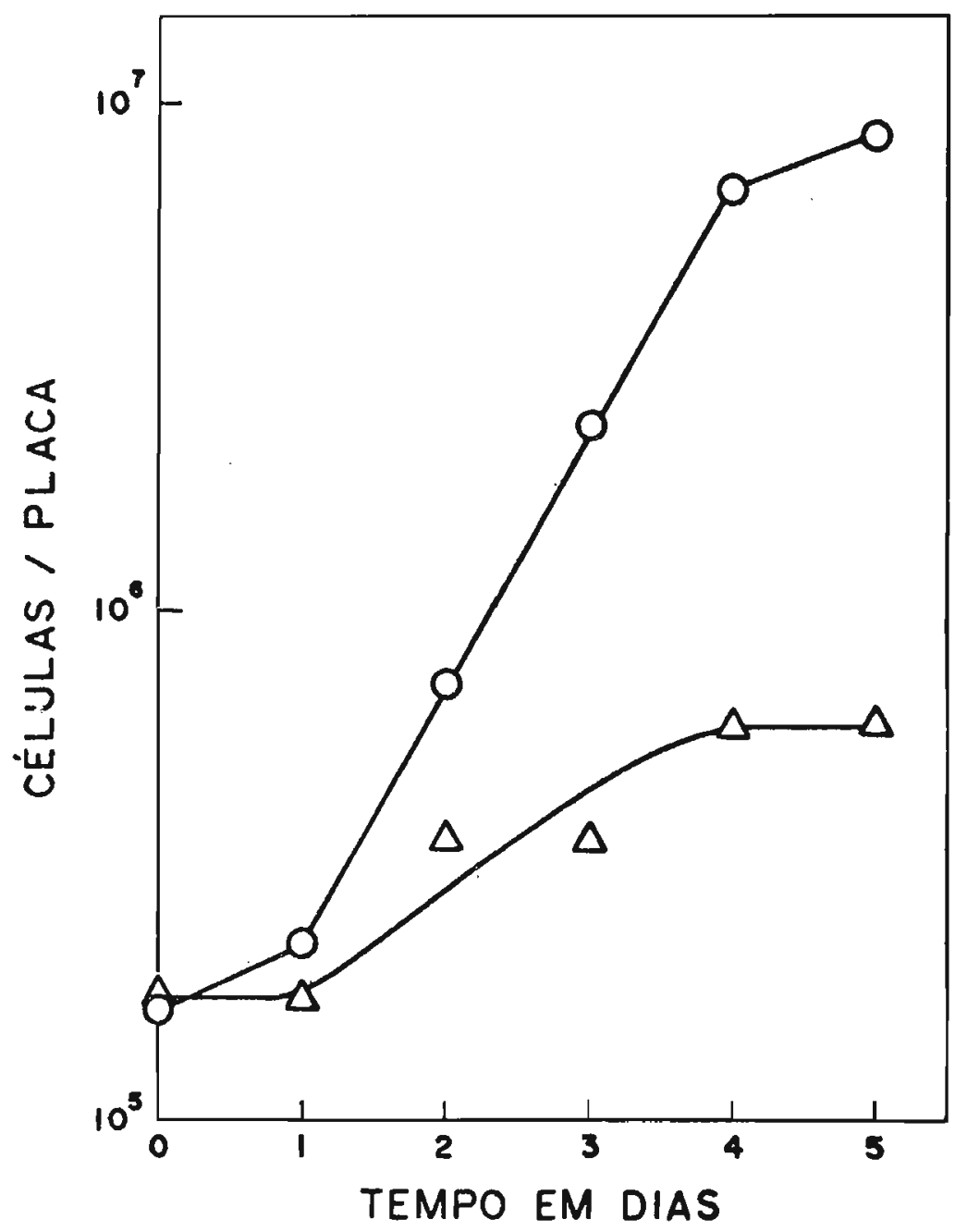

Fig. 19 - Curvas de crescimento para células STl mantidas em 18 FCS $(\Delta-\Delta)$ ou $10 \%$ FCS $(0-0)$.

e a densidade de saturação são proporcionais à concentração de soro, indicando que a linhagem STl é dependente de soro. Para comparação apresenta-se resultados obtidos para a linhagem SV3T3 na fig. 20. Estes dados, resumidos na tabela III, mostram que em 108 de soro células STI se comportam como a linhagem SV3T3: empilham e atingem alta densidade de saturação (da ordem de 10 vezes maior que cêlulas 3T3). Em 18 de soro, entretanto, SV3T3 cresce com o mesmo tempo de dobramento e atinge alta densidade de saturação enquanto o crescimento de células STI, em baixas 


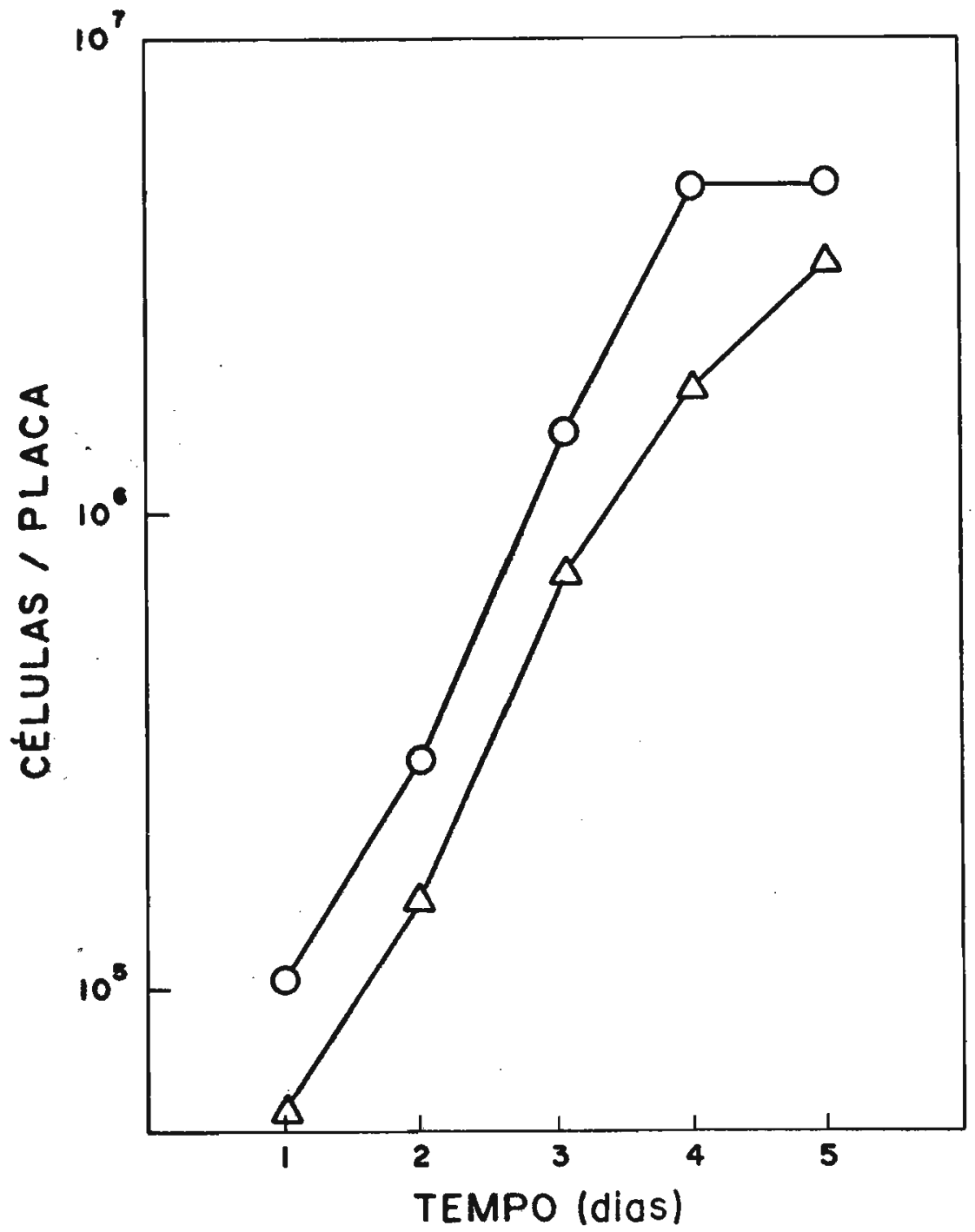

Fig. 20 - Curvas đe crescimento para cêlulas sv3T3 mantidas em 18 FCS $(\Delta-\Delta)$ ou $10 \%$ FCS $(0-0)$.

concentrações de soro, è reduzido. A tabela III mostra ainda que células STl, ao contrārio da linhagem parental 3T3, são cạ pazes de crescer em suspensão, isto è, não dependem de uma superfície sólida para crescer, e apresentam a metade do complemento cromossômico de células 3T3, ou seja, possuem apenas 40 cromossomos.

A aplicação de nosso teste rotineiro de triagem (fig. 18) revelou que cêlulas STl são apenas parcialmente dependentes 
de soro: a síntese de DNA è reduzida quando a concentração de soro é passada de 5 para $0,2 \%$ mas um nível significativo de sín tese permanece (20\% após 24 horas de incubação em baixo soro), sendo as células carenciadas passĩveis de reestimulação por reađição de soro. Além disso as células STl diferem da linhagem parental por não responderem a PF e serem inibidas por concentrações fisiológicas de hidrocortisona (100 ng/ml) ao invés de estimuladas.

$\mathrm{Na}$ verdade experiências posteriores mostraram (tabela IV) que cēlulas STl não respondem à maioria dos hormônios fatores que agem sobre a linhagem parental 3T3. Somente hidrocortisona tem efeito sobre STl em concentrações fisiológicas ,pois insulina sō é ativa em doses altas enquanto albumina apresenta um fator ativo de natureza ainda indefinida (ver a seção $3.7)$.

Resumindo, podemos dizer que a linhagem STl exibe, em cultura, um fenótipo típico de fibroblasto transformado. o interesse nesta linhagem cresceu quando tivemos indícios de que hidrocortisona induzıa em STl uma transição de um fenötıpo trans formado para um fenôtıpo "normal". Dadas as vantagens óbvias de uma célula deste tipo os efeltos de hidrocortisona nestas células foram estudados com cuidado.

\subsection{Efeito de Hidrocortisona}

O efeito de hidrocortisona na curva de resposta de dose para soro pode ser visto na fig. 21. E possivel notar que quando o esteróide é adicionado ao mesmo tempo que o soro 


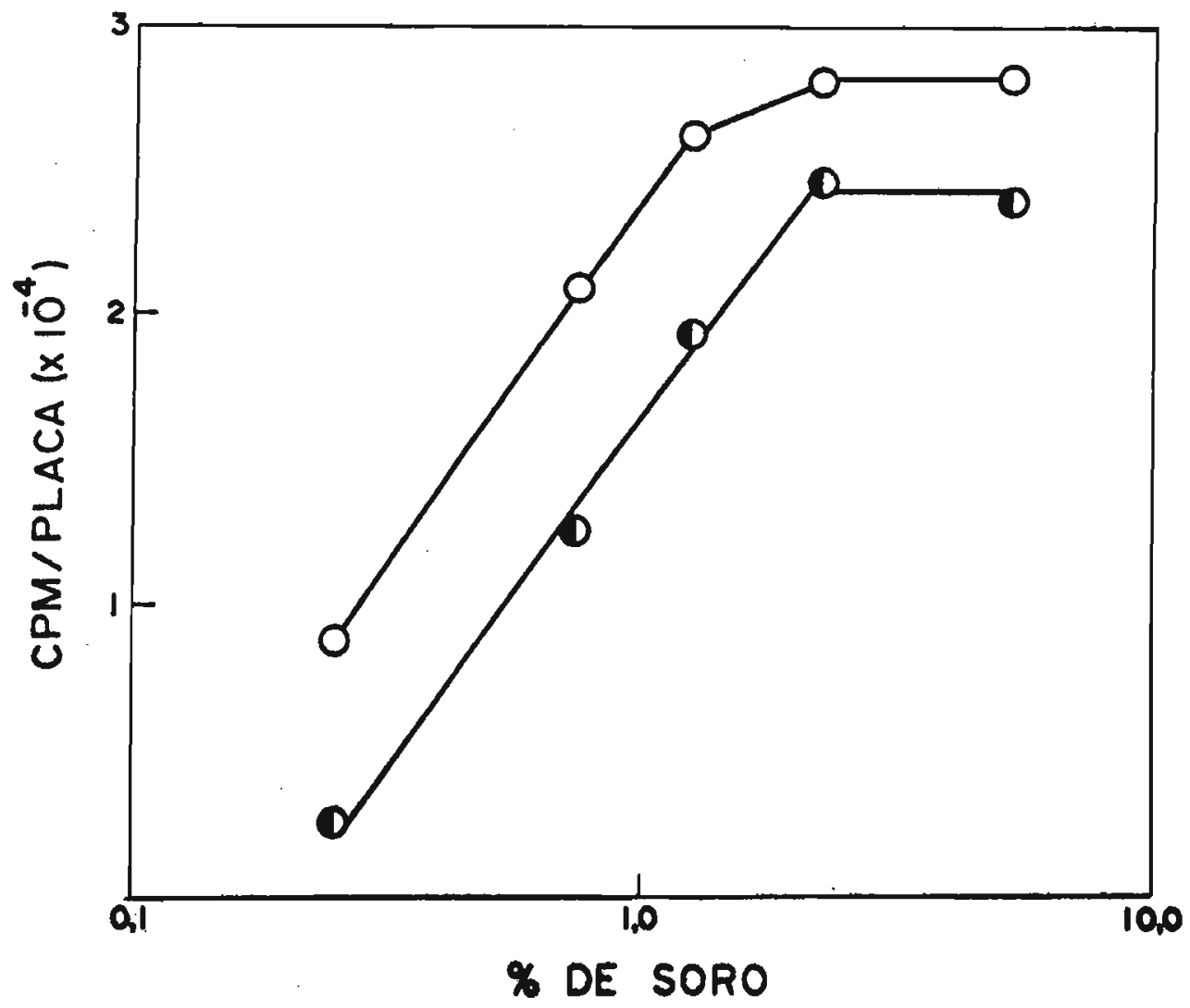

Fig. 21 - Curva de dose de soro para células STl na ausência $(0-0)$ ou na presença (0-0) de hidrocortisona $(300 \mathrm{ng} / \mathrm{ml})$. Atividade estimulatória da sintese de DNA, medida conforme Métodos.

célula STl em repouso, a curva de dose fica desviada para concentrações mais altas de soro. Alëm disso o efeito inibitörio de hidrocortisona sobre a síntese de DNA é tanto maior quan to menor a concentração de soro (fig. 22). Assim a sintese de DNA residual encontrada em células mantidas em baixo soro $(0,28)$ é essencialmente abolida por adição de hidrocortisona ao meio. A ação inibitória de hidrocortisona aumenta progressiva mente com o tempo de incubação alcançando nível máximo após 20 horas (fig. 23). 


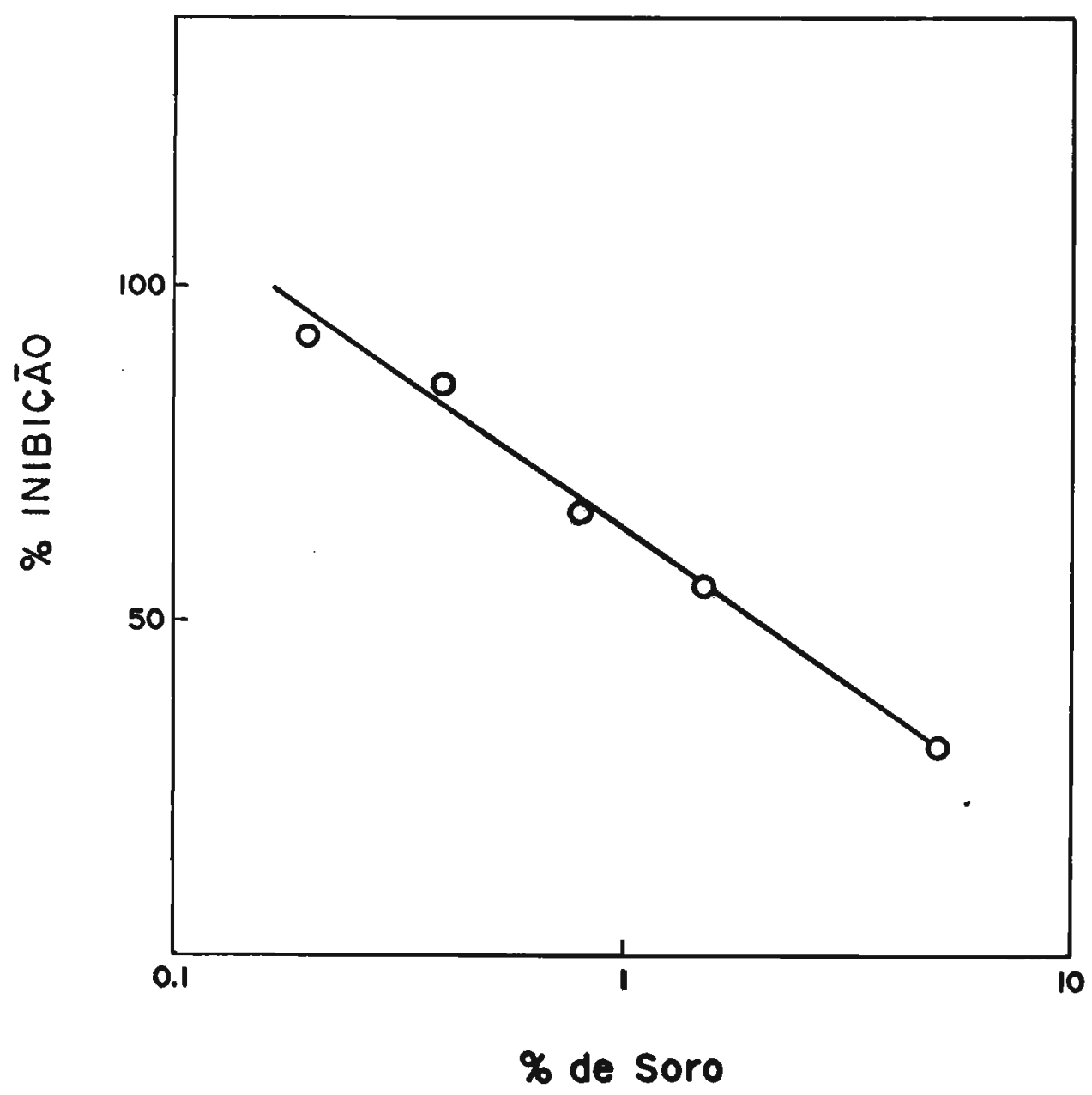

Fig. 22 - Efeito da concentração de soro na atividade inibitória da sintese de DNA por hidrocortisona $(300 \mathrm{ng} / \mathrm{ml})$ em células STl.

A inibłção da sintese de DNA por hidrocortisona não é devida à morte de cêlulas. A eficiência de plaqueamento (dẹ terminada segundo o item 7 de Mëtodos) è a mesma tanto na presença como na ausência de hidrocortisona: 52,0 e 52,78 respectivamente.

Células STl crescem bem tanto em soro de vitelo como em soro fetal bovino formando multicamadas de células empilha das e desorganizadas e alcançando altas densidades de satura ção (tabela v). A adição de hldrocortisona causa uma diminutção 


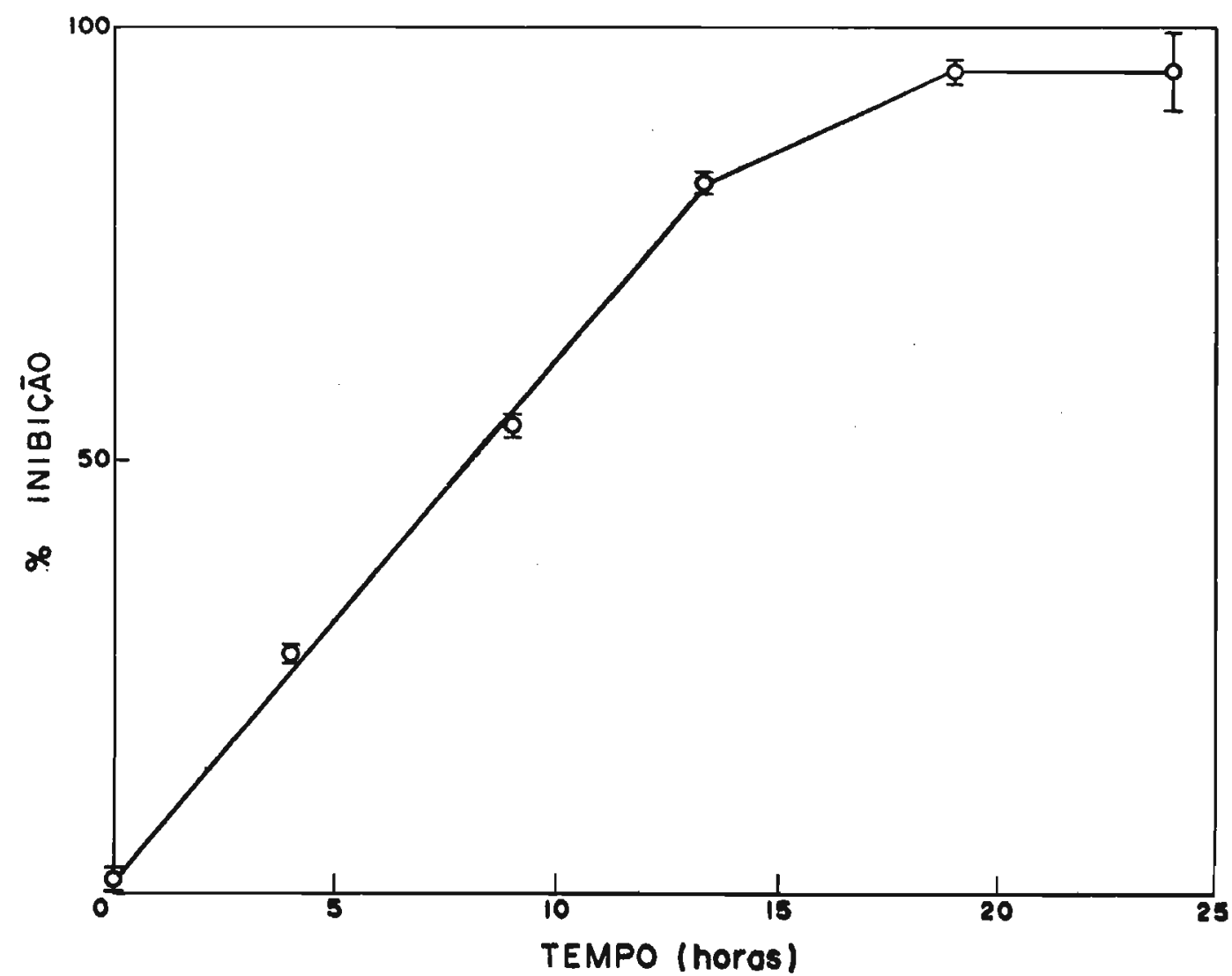

F1g. 23 - Cinētica da inıbıção da sintese de DNA por hidrocor tisona $(300 \mathrm{ng} / \mathrm{mI})$ em células STl.

Tabela V - Efeito de hidrocortisona na densidade de saturação de células STl

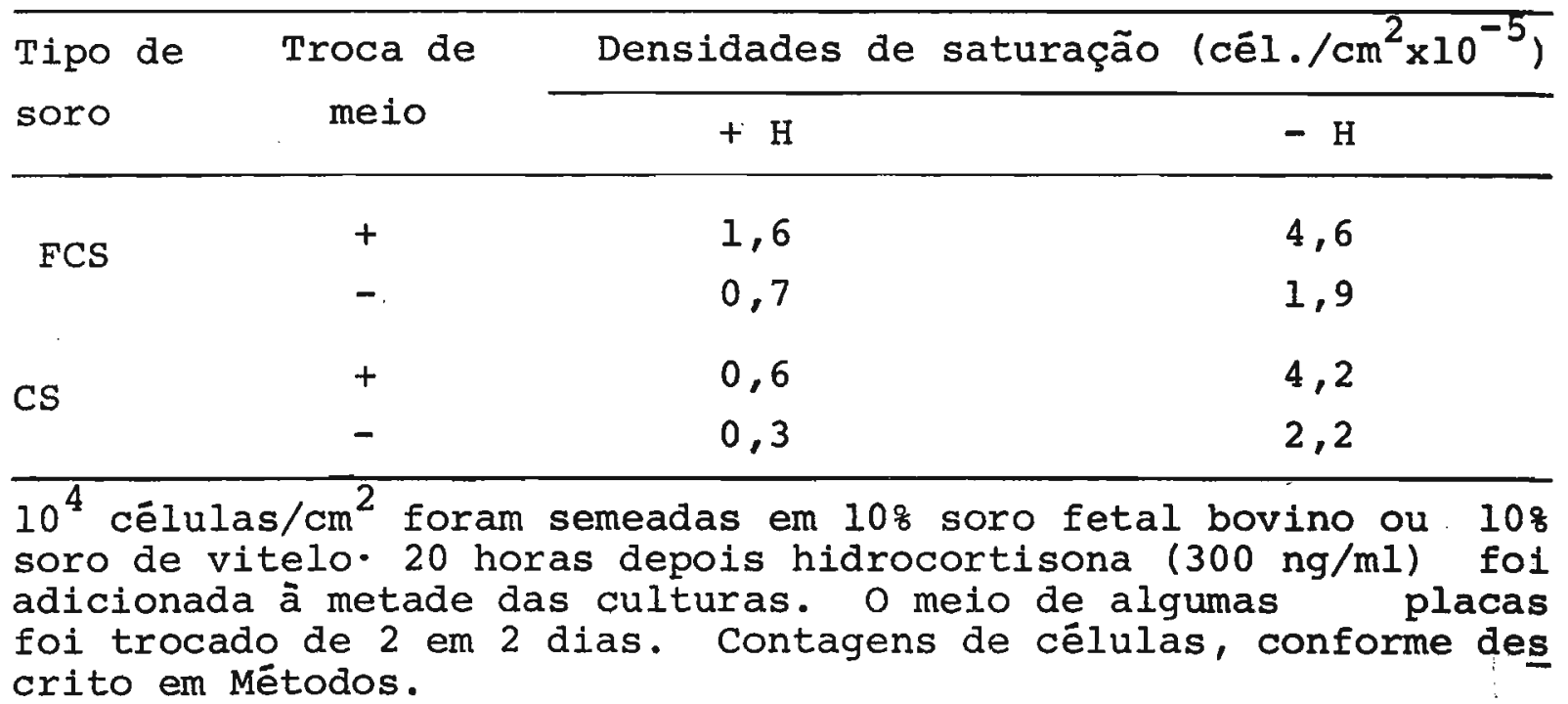


na densidade de saturação de 3 vezes em soro fetal bovino e 7 vezes em soro de vitelo (tabela V) indicando que na presença de hidrocortisona soro fetal bovino suporta melhor o crescimento que soro de vitelo. Este efeito pode ser visto também na tabela IV em termos de estimulação da síntese de DNA. Na presença do hormônio as células tornam-se achạtadas e formam monocama da regular ao atingirem a densidade de saturação (em ambos os tipos de soros).

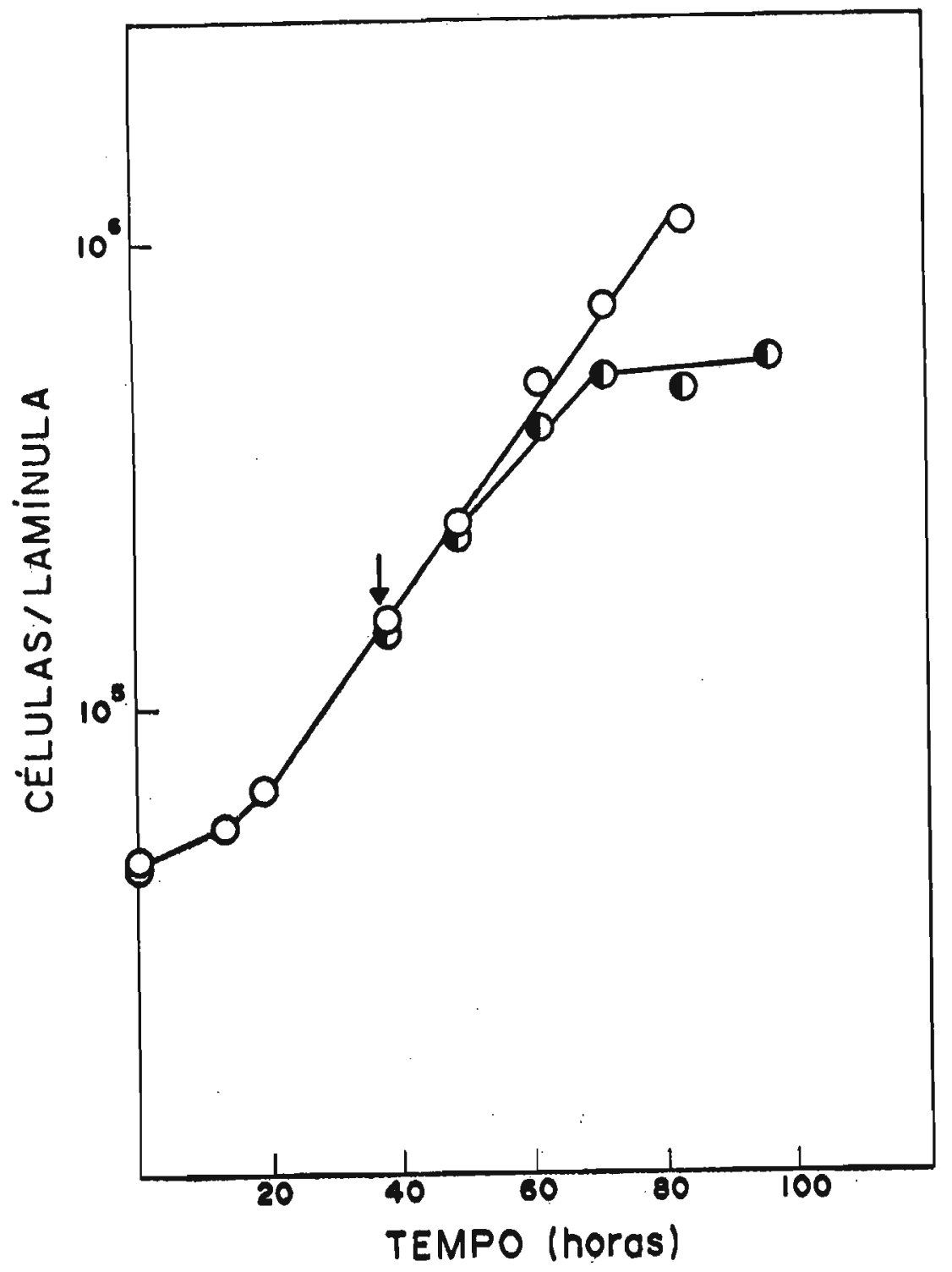

F1g. 24 - Efelto de hidrocortisona na velocidade de crescimento de cêlulas STl. A seta indica o ponto em que hidrocortisona ( 300 $\mathrm{ng} / \mathrm{ml}$ ) fol adicionada $\longrightarrow$. Controle: 0 . 
o tempo de duplicação ( $T_{D}$ ) é também alterado por hidro cortisona. Quando o hormônio é adicionado a uma cultura em crescimento exponencial $T_{D}$ passa de 15 para 20 horas (fig. 24). Esta alteração na velocidade de crescimento ocorre 13 a 14 horas após a adição de hidrocortisona.

O efeito de hidrocortisona foi estudado também em colô nia de cëlulas STl, obtidas segundo protocolo descrito no item 7 de Mētodos. Na ausência de hidrocortisona as colônias são desorganizadas, frouxas (com cëlulas fracamente aderidas umas às outras) e apresentam maior grau de empilhamento no centro da co lônia. Na presença do hormônio as células da região central da colônia são isométricas e fortemente aderidas umas às outras. Co lônias de cëlulas STl crescendo em 10 z de soro foram submetidas a tratamento com baixo soro ou baixo soro + hidrocortisona por 24 horas e, neste ponto, reestimuladas por adição de diferen tes concentrações de soro. A análise do padrão dé distribuição de núcleos marcados, por autorradiografia, encontra-se esquematizada na fig. 25 e ilustrada na fig. 26. Na ausência de hidrocortisona a frequência de núcleos marcados é proporcio nal à concentração de soro mas estes se encontram distribuídos homogeneamente por toda a colônia. Por outro lado na presença de hidrocortisona os núcleos marcados ficam restritos à periferia da colônia sendo que aqui (como em colônias de células 3T3) o halo de núcleos marcados é proporcional à concentração de soro.

Ao contrário da linhagem parental 3T3, células STl pla queadas em suspensão de metilcelulose (item 11 de Métodos) 


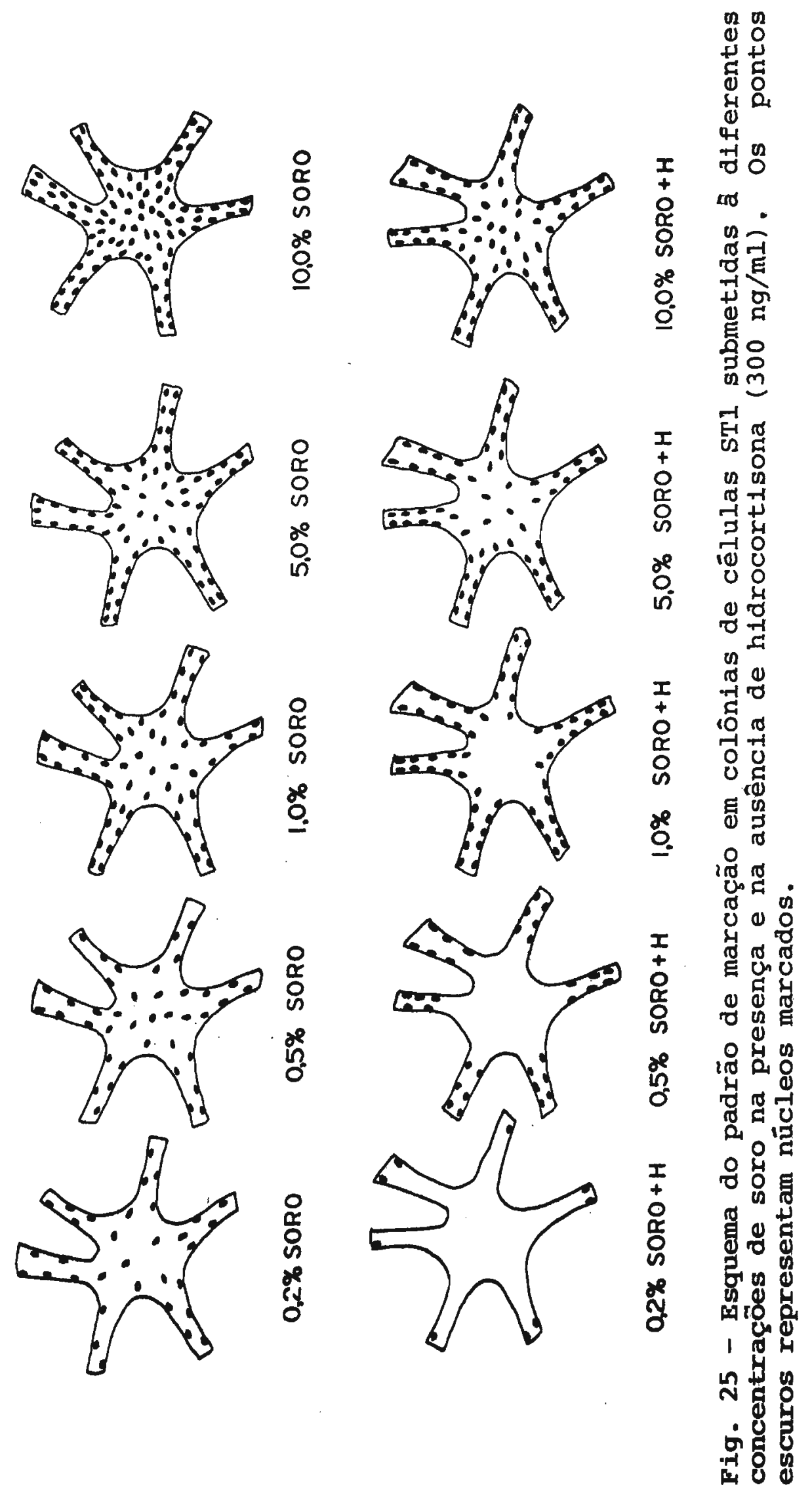




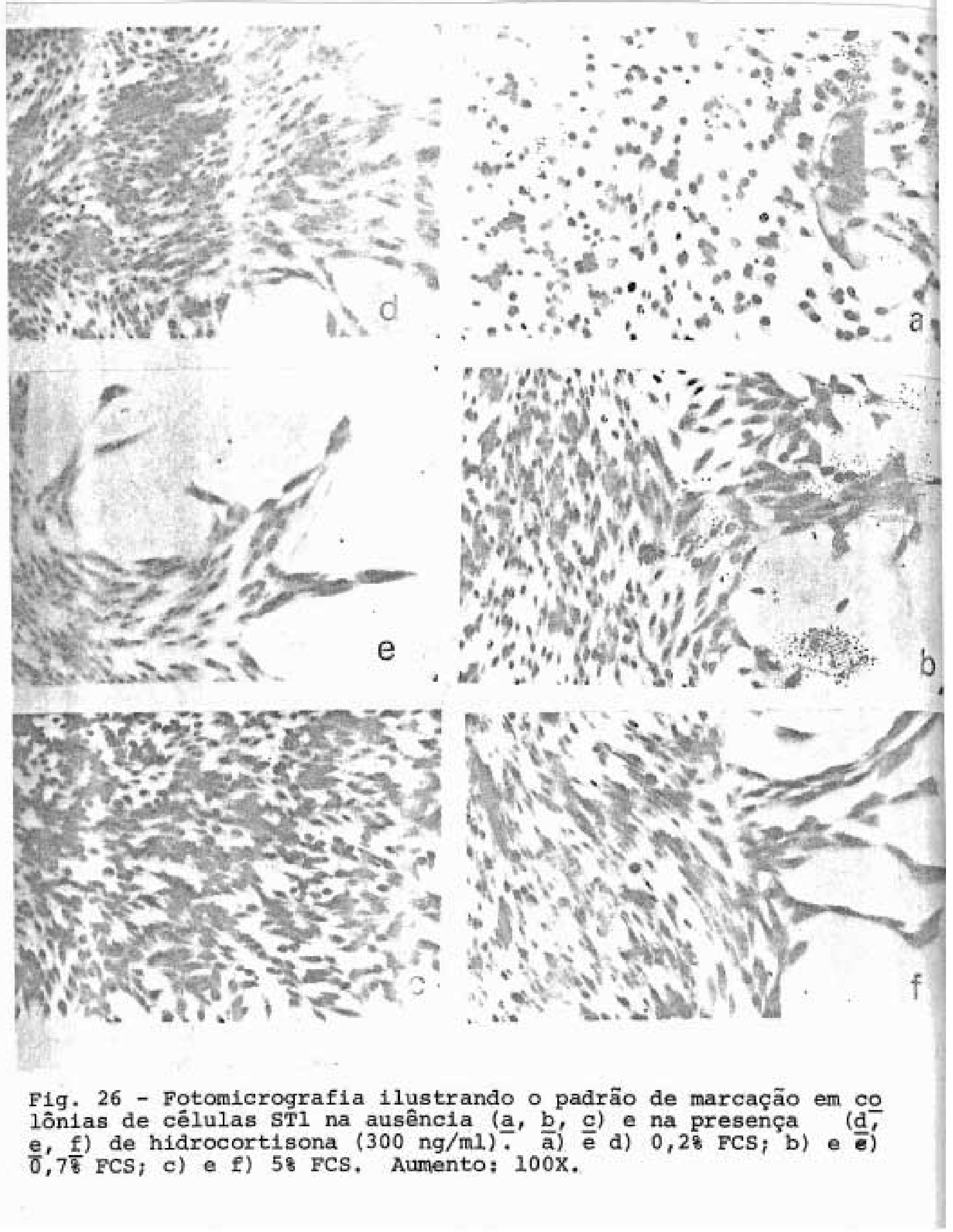


desenvolvem colônias macroscópicas de cerca de $3 \mathrm{~mm}$ de diâmetro em 21 dias (ver ilustração na fig. 27). Eficiências de plaquea mento de 1 a $5 \%$ foram obtidas em meio metocel contendo $10 \%$ de soro enquanto com 0,2 a $5 \%$ de șoro a eficiència de plaqueamento foi sistematicamente zero. Células STl plaqueadas em meio metocel + hidrocortisona não formaram colônias. Esta inibição da formação de colônias por hidrocortisona não é devida à morte das células uma vez que a remoção da hidrocortisona (por lavagem e realimentação das placas com meio metocel sem hidrocortisona) 21 dias após o plaqueamento levou, aos 46 dias de plaqueamento, ao surgimento de colônias do mesmo tamanho e com a mesma eficiência de plaqueamento apresentada, aos 21 dias, por culturas paralelas mantidas na ausência do hormônio.

3.4. Anālise da Atividade de Diversos esterôides Sobre Cêlu las STl

A ação inibitória de uma série de esteróides sobre a sintese de DNA fol investigada a fim de determinar quais os grupos funcionais necessáríos para a atividade inibitória. Os resultados são apresentados na fig. 28 e na tabela VI onde fo ram colocados dados comparativos da estimulação de células 3T3 pelos diversos esteróides. E possível verificar que: a) a con figuração do c-20 e c-21 de hidrocortisona (comum a todos os glicocorticōides) è necessāria porque a substituição de $-\mathrm{CH}_{2} \mathrm{OH}$ em hidrocortisona por $-\mathrm{CH}_{3}$ em progesterona causa uma diminuição acentuada na atividade inibitória e porque os esteróides sexuais (que não possuem $\mathrm{C}-20$ e $\mathrm{C}-21$ ) foram completamente inativos; b) - grupo -OH do C-11 que é essencial para atividade glicocorticôide 

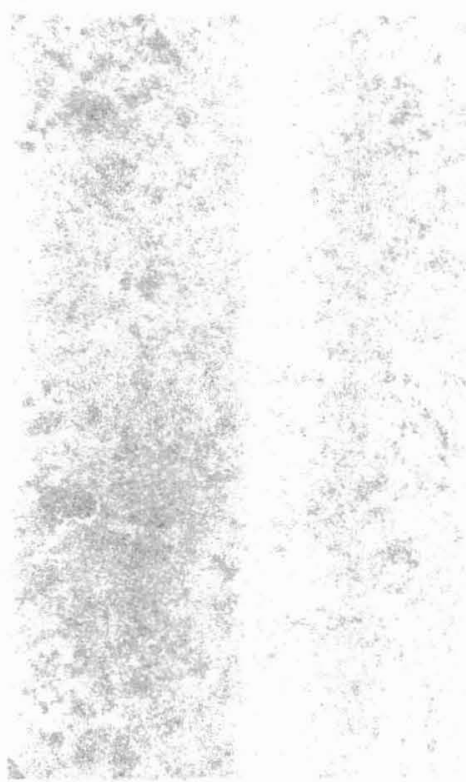

$x=-32$

Fig. 27 Aspecto d colônias desenvolvidas em suspensão de me tilcelulose por células a) 303 ; b) SV3T3; c) sIl na ausência de hidrocortisona; $\mathrm{ng}(\mathrm{ml})$. Aumento:

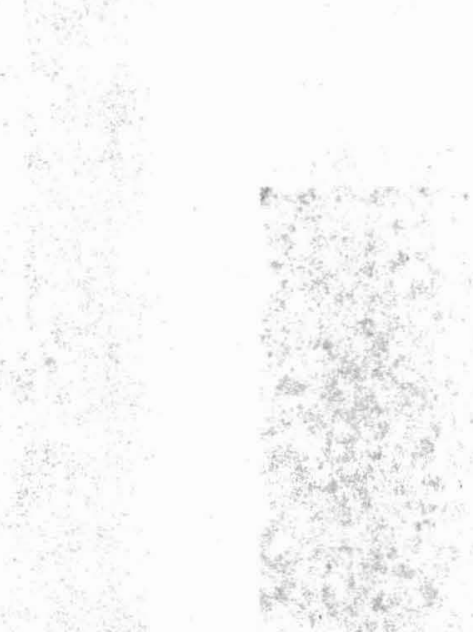



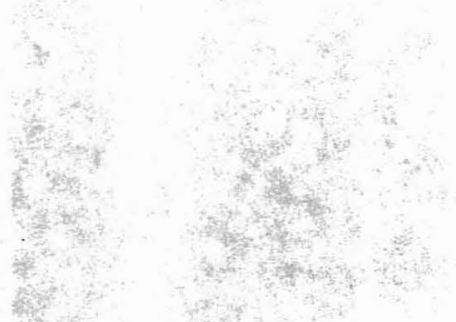

thents

3. 64

He

g)

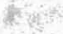

ing
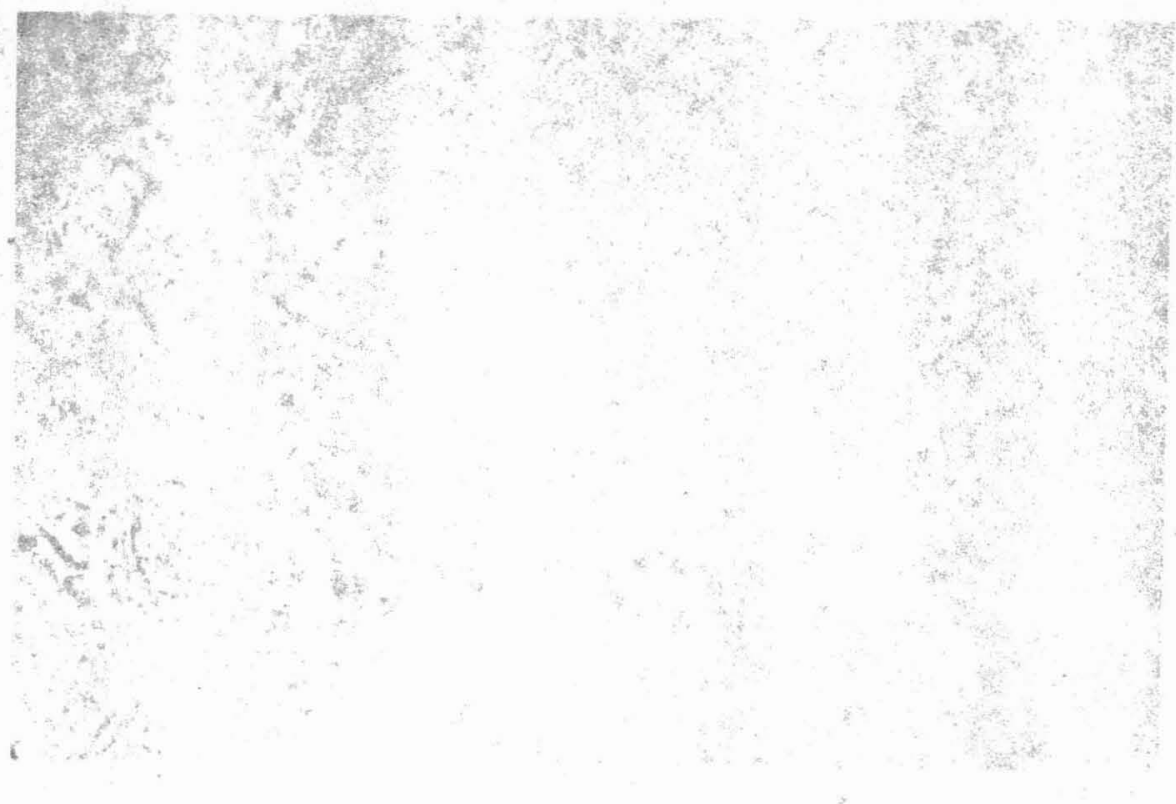


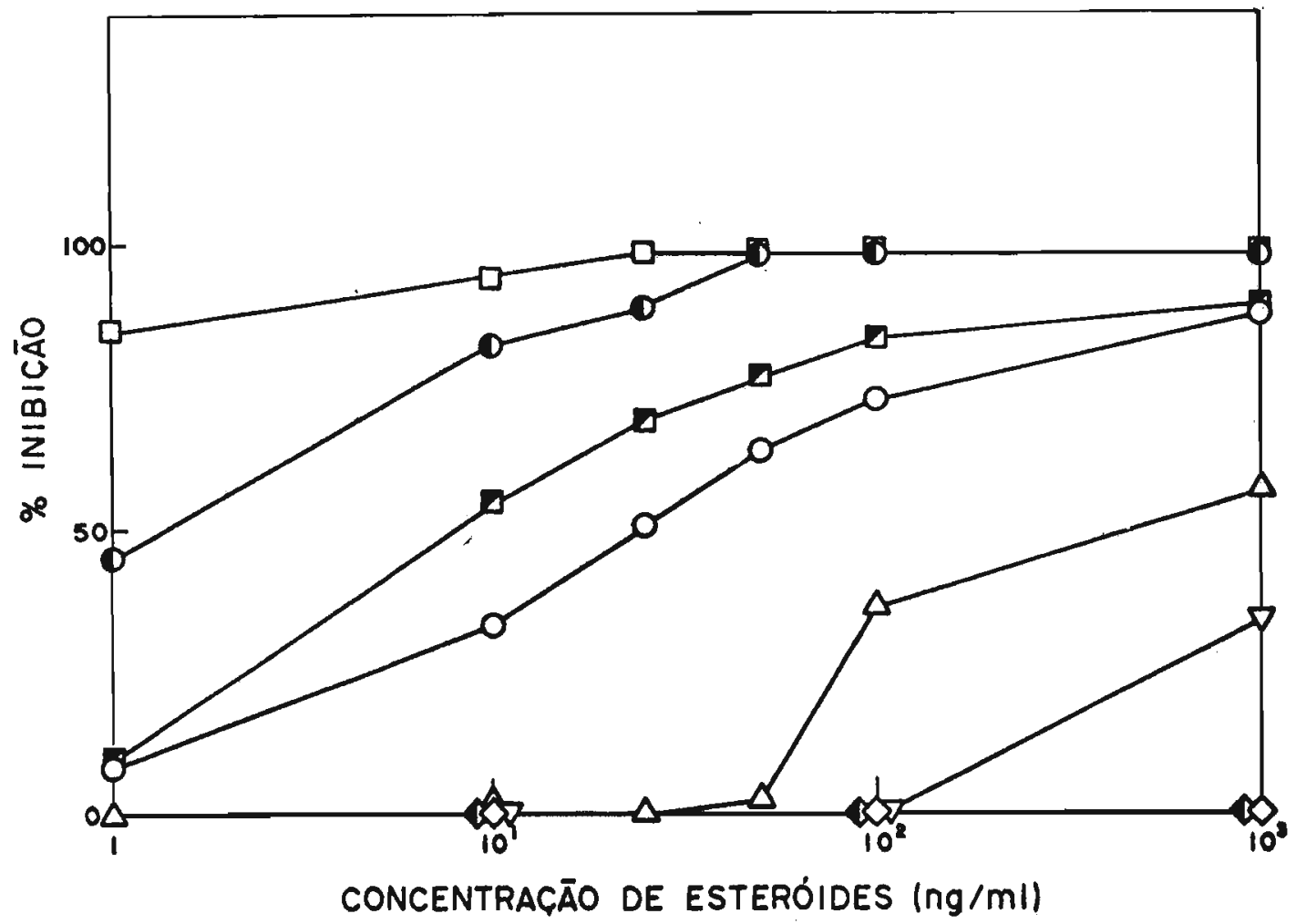

Fig. 28 - Inibição da sintese de DNA em cêlulas STl por diversos esteróides; curvas de dose. Os esteróldes foram adicionados a células carencladas para soro. Após 20 horas de incubação, timidina ${ }^{3} \mathrm{H}$ fol incorporada por 4 horas $\mathrm{e}$ a incorpora ção em DNA medida como descrito em Métodos. \& de inibiçăo fol obtida por comparação de culturas tratadas com culturas não tratadas. $\square-\square$ dexametasona; $\longrightarrow$ hidrocortisona; $\square-\square$ desoxicorticosterona; $0-0$ cortisona; $\Delta-\Delta$ progesterona; $\nabla-\nabla 17, \beta-$ -estradiol; $\diamond-\diamond$ testosterona; $\diamond-\diamond$ dihidrotestosterona.

(BUSH \& MALESH, 1959) não é necessārio para a atividade inibitória em células STl porque desoxicorticosterona (que não possui $-\mathrm{OH}$ no $\mathrm{C}-11$ ) e cortisona (que possui $\mathrm{C}=\mathrm{O}$ no $\mathrm{C}-11$ ) são bastante ativos. Portanto a atividade inibitōria de esteróides em células STl não correlaciona perfeitamente com suas atividades glicocorticóides pl enquanto a atividade estimulatória destes esteróides sobre células $3 \mathrm{~T} 3$ segue perfeitamente a atividade glicocorticóide (THRASH et al., 1974 e resultados obtidos por nós, apresentados na tabela VI). 


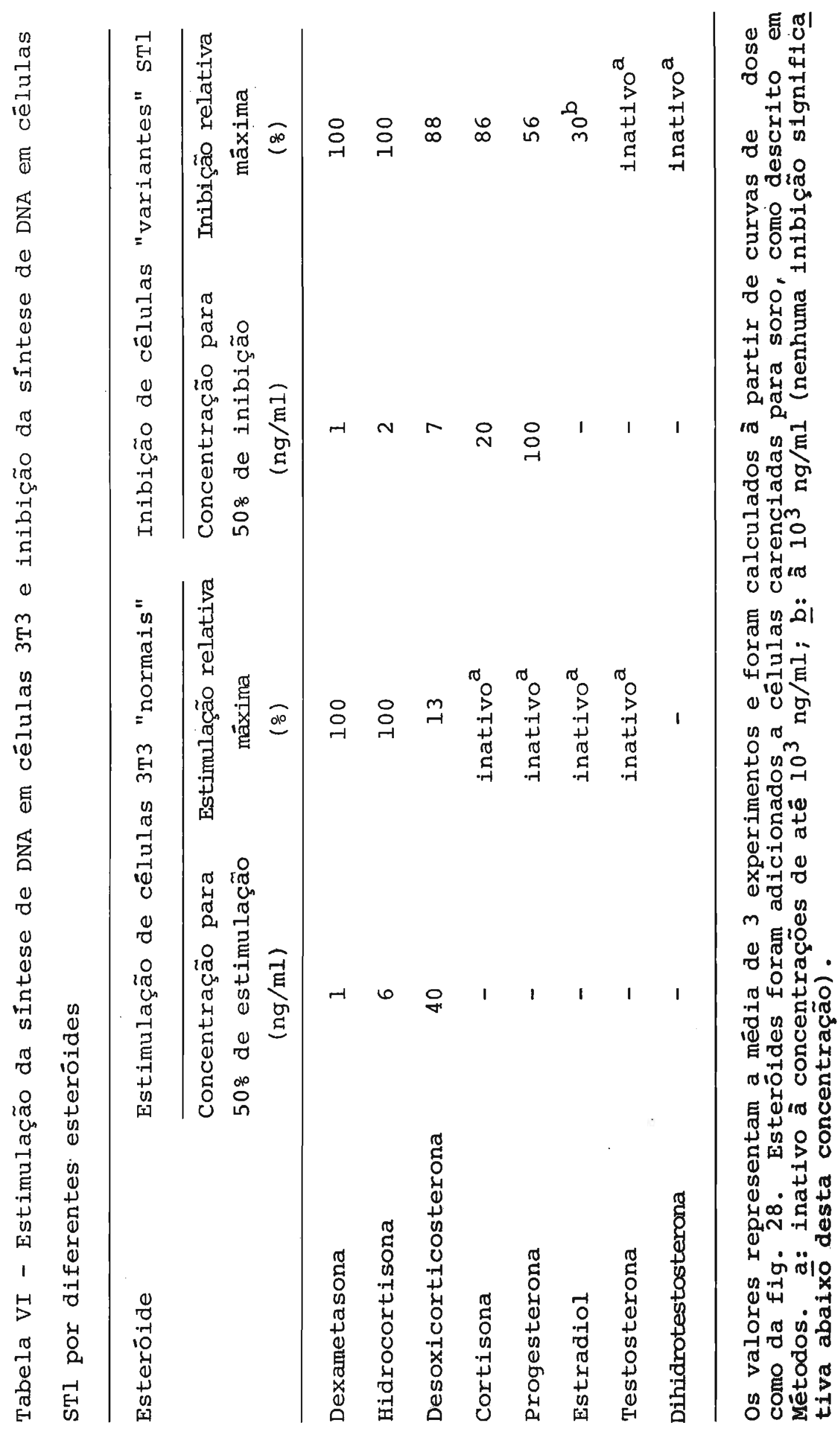


3.5. Ação de hidrocortisona no ciclo celular

Resultados como os das figs. 23 e 24 sugeriram-nos que a ação de hidrocortisona podia ser específica para um ponto do ciclo celular anterior à fase S. Particularmente interessava-nos saber se este ponto estaria na transição $\mathrm{Go} \rightarrow \mathrm{Gl}^{\mathrm{C}}$. Para testar esta hipótese, hidrocortisona foi adicionada à culturas crescendo exponencialmente na presença de 5\% de soro. Durante as 13 horas seguintes o "pool" de células em $\mathbf{S}$ foi estimado atravēs de pulsos de timidina ${ }^{3} \mathrm{H}$ e autorradiografia. Os résultados, apresentados na fig. 29, revelaram que: a) a porcentagem de células em $S$ permanece constante pelas primeiras 5 horas; b) à partir daí a porcentagem de cêlulas em s cai progressivamente por 6 horas atingindo então um novo "plateau". Estes resultados seriam exatamente os esperados se hidrocortisona apenas afetasse células em Gl, 5 ou mais horas antes de $\mathrm{S}$; é provāvel que só não sejam afetadas as células que estão em $\mathrm{Gl}^{\mathrm{C}}$. Se esta interpretação estiver correta, os dados da fig. 29 permitem estimar $\mathrm{Gl}^{\mathrm{C}}$, como sendo de 5 horas, e s entre 6 e 7 horas (à partir do tempo necessārio para a porcenta gem de núcleos marcados ir de um "plateau" a outro).

Os dados das figs. 24 e 29 indicam que hidrocortisona não deve interferir com o fluxo de células atravēs da mitose. Portanto, se hidrocortisona for adicionada a uma cultura em cres cimento exponencial, é de se prever que o índice mitótíco perma necerá constante por um periodo de tempo igual a $\mathrm{Gl}^{\mathrm{C}}+\mathrm{S}+\mathrm{G} 2+\mathrm{M}$. Esperava-se que este tempo fosse maior que 11 horas $\left(G I^{\mathbf{C}}+\mathrm{S}\right) \mathrm{e}$ menor que 15 horas $\left(\mathrm{T}_{\mathrm{D}}\right.$ na ausência de hidrocortisona, que repre senta uma boa aproximação do tempo médio de geração (PAINTER \& 


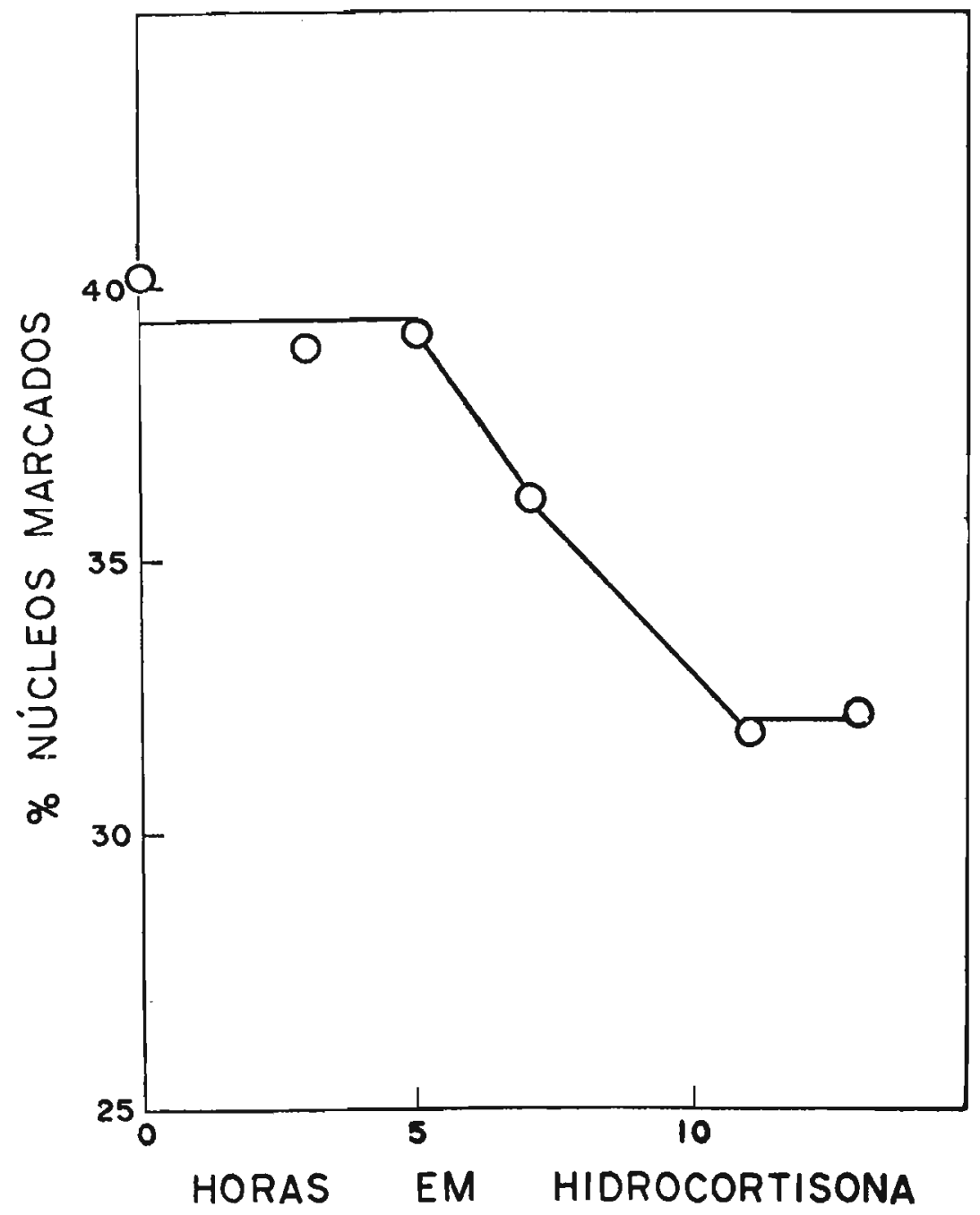

Fig. 29 - Cinētica do efeito de hidrocortisona sobre células STl crescendo exponencialmente: Medidas do Indice de marcação. Hidrocortisona $(300 \mathrm{ng} / \mathrm{ml})$ adicionada em $t=0$. Pulsos de timidina ${ }^{3}$ (1 hora, $\left.10^{-7} \mathrm{M}\right)$. Detalhes do protocolo em Métodos.

MARR, 1968). Experiênclas deste tipo foram realizadas e os resultados encontram-se na fig. 30. Conforme a previsão anterior - indice mitótico cai somente 14 horas após a adição do hormônio. Era de se esperar que a queda fosse brusca uma vez que a mitose é, em geral, de curta duração. Note-se que o tempo de mitose pode ser calculado, com boa aproximação, à partir do Indi ce mitótico $(0,053)$ e do $\mathrm{T}_{\mathrm{D}}(15$ horas $)$ em crescimento exponencial e "steady-state", obtendo-se o valor de 0,6 horas. Levando-se 
em conta que $\mathrm{Gl}^{\mathrm{C}}+\mathrm{S}=11$ horas (da fig. 29), $\mathrm{Gl}^{\mathrm{C}}+\mathrm{S}+\mathrm{G} 2+\mathrm{M}$ $=14$ horas (da fig. 30) e que $M=0,6$ horas, calcula-se que G2 deve ser igual a 2,4 horas. Aceitando-se o raciocinio desenvolvido acima, è razoável concluir-se que hidrocortisona cau sa diminuição na velocidade de crescimento ( $T$ passando de 15 para 20 horas) por aumentar o tempo médio de residência das cẹ lulas no estado Go ou por diminuir a probabilidade da transição Go $\rightarrow \mathrm{Gl}^{\mathrm{C}}$.

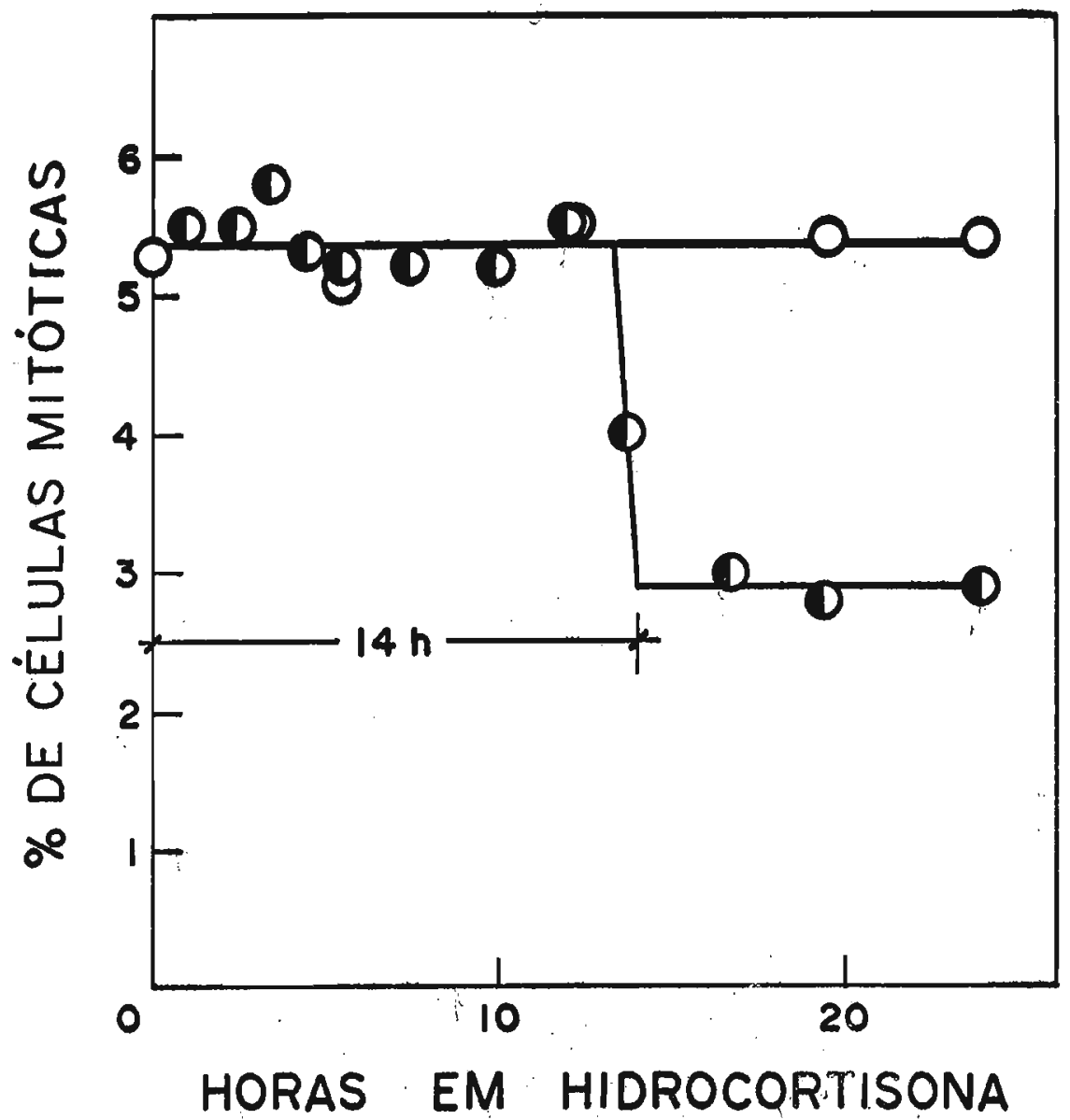

Fig. 30 - Cinética do efeito de hidrocortisona sobre células STl crescendo exponencialmente: Medidas do Indice mitótico. $0-0$ Controle (5\% FCS ); $05 \%$ FCS + hidrocortisona (300 ng/ml). 


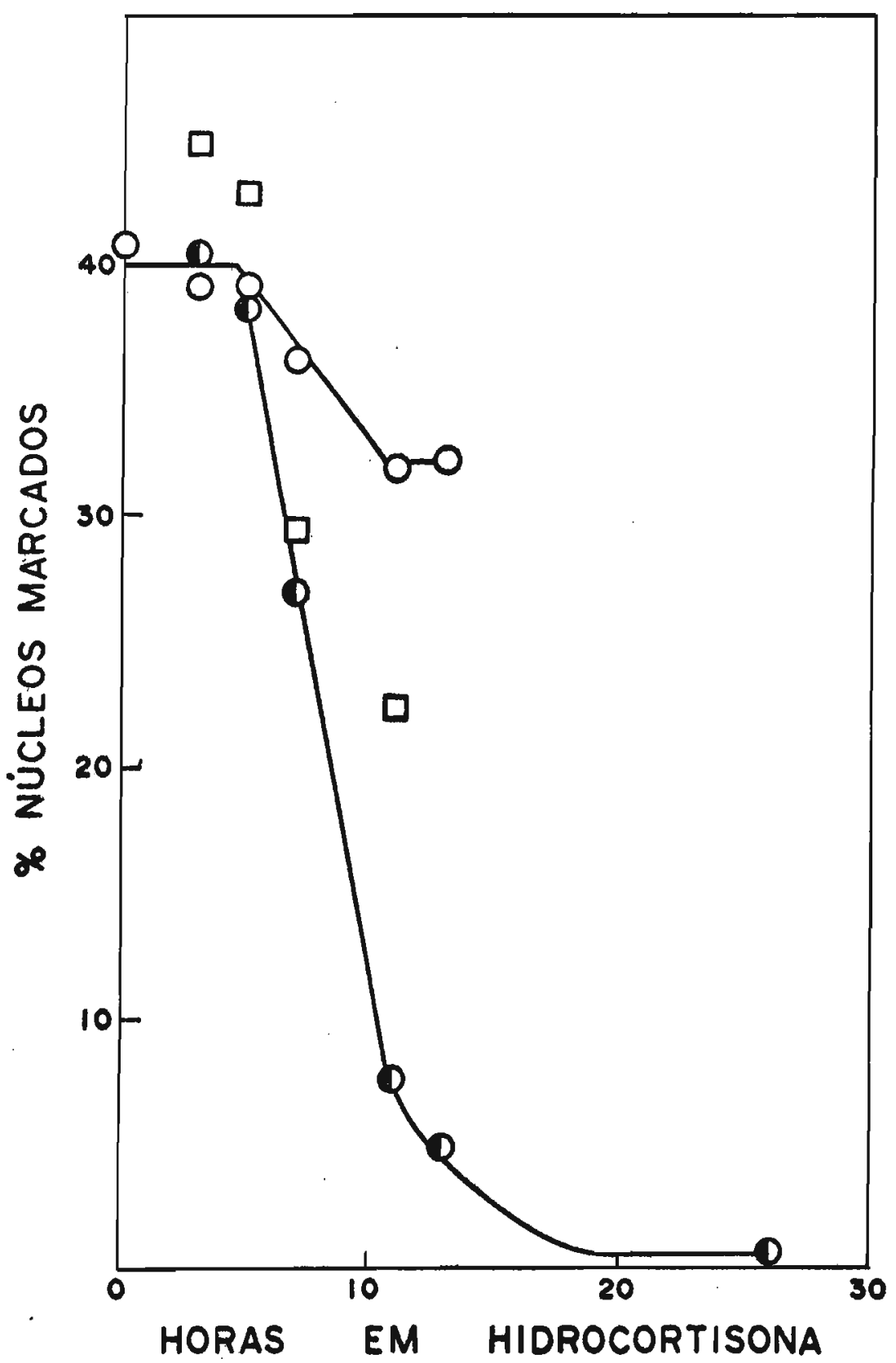

Fig. 31 - Cinētica do efeito da redução do soro e/ou adição de hidrocortisona sobre células STl crescendo exponencialmente:Me didas do indice de marcação. Pulsos de timina $3_{\mathrm{H}}$ ( 1 hora, 10-7M). Detalhes do protocolo em Método. $\square-0,28$ FCS; $0-00,28$ FCS + hidrocortisona $(300 \mathrm{ng} / \mathrm{ml}) ; 0-058 \mathrm{FCS}+$ hidrocortisona $(300$ $\mathrm{ng} / \mathrm{ml}$ ).

Dado que o efeito de hidrocortisona è muito mais acentuado em baixas concentrações de soro, um outro tipo de experiência também foi feito. Células crescendo exponencialmente em 
$5 \%$ de soro foram transferidas para $0,2 \%$ de soro ou $0,2 \%$ de soro + hidrocortisona e a porcentagem de nücleos marcados (fig. 31) e o indice mitótico (fig. 32) foram medidos periodicamente.

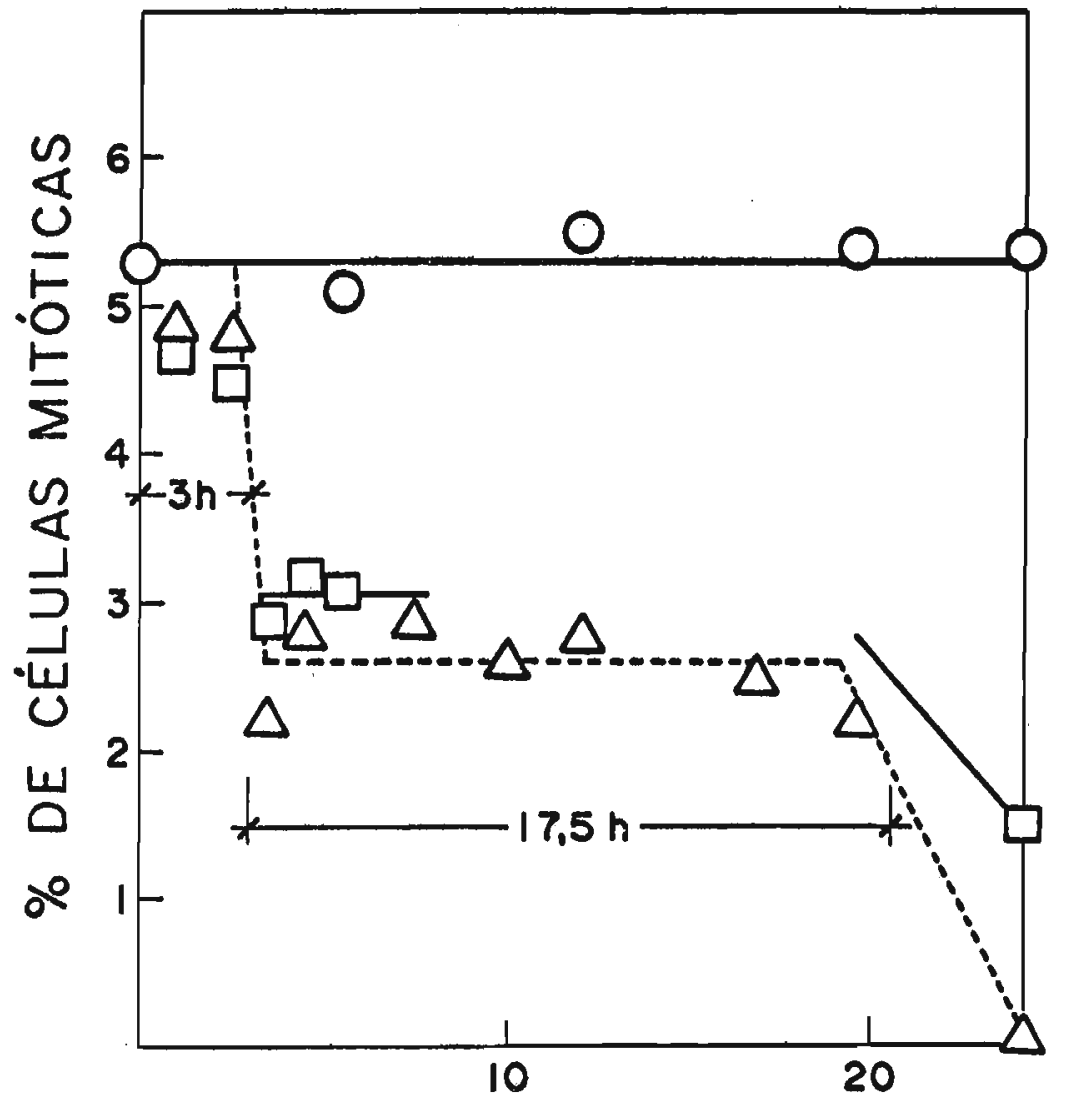

HORAS APÓS A REDUÇĀO DO SORO

Fig. 32 - Cinētica do efeito da redução do soro e/ou adição de hidrocortisona sobre cëlulas STl crescendo exponencialmente:Me didas de indice mitôtico o-o controle (5\% FCS); 口-口 $0,2 \bar{z}$ FCS; $\Delta-\Delta 0,2 \%$ FCS + hidrocortisona (300 ng/ml).

A curva da fig. 31 mostra que: a) como para o caso de 58 de so ro, o Indice de marcação não cai durante as primeiras 5 horas; b) na verdade em culturas transferidas para 0,28 de soro sem hormônio existe uma tendência para aumentar o índice de marcação nas primeiras horas; c) após 5 horas o Índice de marca ção cai continuamente atē nîveis negligenciáveis no caso de 
$0,2 \%$ + hidrocortisona, levando cerca de 20 horas para atingir o mínimo. Comparando as curvas da porcentagem de núcleos marcados para $5 \%$ de soro + hidrocortisona (fig. 29) e 0,28 de soro + hidrocortisona (fig. 31), deve-se destacar dois pontos:a) o ombro, durante o qual o indice de marcação é constante, é ○ mesmo ( 5 horas) e corresponderia a $\mathrm{Gl}^{\mathrm{C}}$; b) $\circ$ tempo durante $\circ$ qual o indice de marcação cai (desde o "plateau" das primeiras 5 horas até o seu valor mais baixo, periodo este que deve ser igual ao comprimento de $S)$ é muito maior para 0,28 de soro thi drocortisona (de 6 a 7 horas). Este último resultado sugere que a redução do soro no meio de cultura diminui a velocidade com que as células atravessam $S$, muito embora não interfira com a entrada em $S$ das células que jã estão comprometidas com a replicação do DNA. Situação equivalente já foi focalizada no caso de células 3T3 (fig. 17a).

Os dados de indice mitótico (fig. 32) estão de acordo com estas interpretações. Três horas após a transferência das culturas para 0,28 de soro + hidrocortisona (ou para 0,28 de soro somente) o indice mitótico cal bruscamente para atingir um patamar cujo valor é $50 \%$ mals baixo e que è mantido por cer ca de 17,5 horas (e à 24 horas o Indice mitótico ê praticamente nulo). Se o "pool" de cêlulas em G2 não fosse afetado pelo tratamento mas o fluxo de células através de $S$ fosse diminuído, os resultados da flg. 32 seriam exatamente os esperados.

Em conclusão pode-se dizer que hã dados convincentes indicando que hidrocortisona interfere apenas com a passagem de células de Go para $\mathrm{Gl}^{\mathrm{C}}$, enquanto a redução do soro parece causar dols efeitos: diminui a probabilidade da transição 
Go $\rightarrow \mathrm{Gl}^{\mathrm{C}}$ e aumenta o tempo necessārio para as células atravessarem S.

3.6. Efeito de Hidrocortisona Sobre a Reestimulação de Células STl Carenciadas para soro

Uma vez verificado que hidrocortisona interfere com a transição Go $\rightarrow \mathrm{Gl}^{\mathrm{C}}$, tornou-se de interesse saber se a resposta de células carenciadas à reestimulação por soro, era alte rada pelo hormônio. Células STl foram carenciadas por 24 horas em 0,28 de soro ou 0,28 de soro + hidrocortisona $e$, em segui da, reestimuladas por adıção de soro. o "lag" que precede a sin tese de DNA fol medido pela incorporação da timıdina ${ }^{3} \mathrm{H}$ em DNA (f1g. 33) ou pela porcentagem de nücleos marcađos(fig. $34 \mathrm{a}$ e b) Estes resultados mostram claramente que o "lag" è maior (14 horas) na presença de hidrocortisona do que na sua ausência (10 horas). A onda de mitoses (fig. 35) das células tratadas com o hormônio também apareceu defasada de 4 horas em relação âs célú las não tratadas, indicando que a diferença se encontra no periodo anterior a $S$ (ver tabela VII). Estes resultados são, por tanto, coerentes com a proposição de que hidrocortisona interfe re somente com a transição Go $\rightarrow \mathrm{GI}^{\mathrm{C}}$.

3.7. Ação de Fatores de Crescimento Sobre Células STI

O corpo de resultados apresentados até aqui mostra que é inapropriado chamar o efeito de hidrocortisona sobre células STl de ação inibitória como o fizemos inicialmente. Na verdade o hormônio induz uma alteração estrutural nestas cēlulas,que 


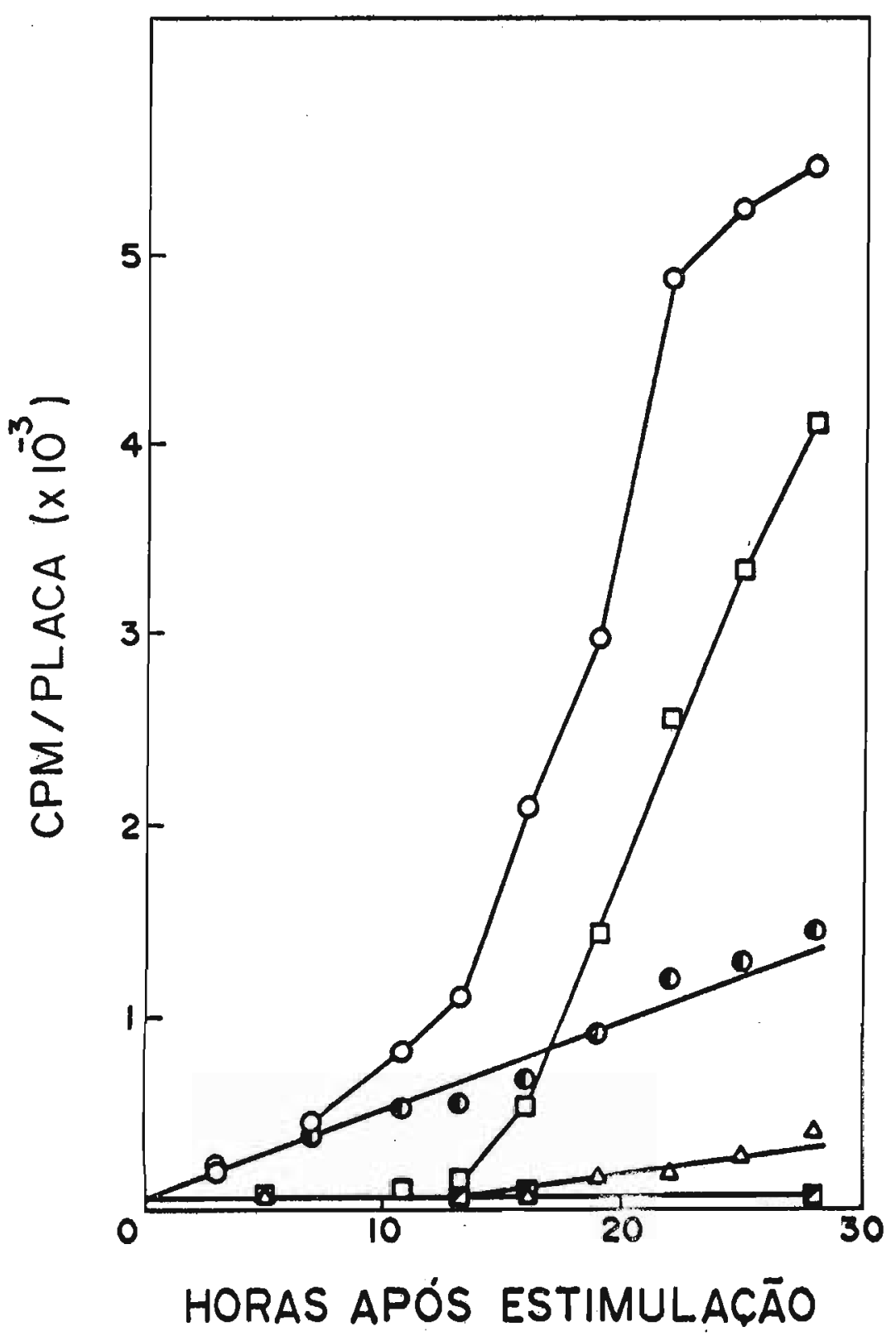

Fig. 33 - Cinética de reestimulação da sintese de DNA em cêlulas STl tratadas ou não com hidrocortisona. $\mathrm{O} \longrightarrow 0,28 \mathrm{FCS} ; 0 \longrightarrow 58$ FCS; - 0,28 FCS + hidrocortisona $(300 \mathrm{ng} / \mathrm{ml}) ;$ प-口 58 FCS + hidrocortisona $(300 \mathrm{ng} / \mathrm{ml}) ; \Delta-\Delta 0,28 \mathrm{FCS}+$ hidrocortisona; es teróide removido em $t=0$.

leva à transição do fenótipo transformado para o "normal". E des necessário enfatizar a importância que teria a elucidação do mecanismo envolvido nesta ação de hidrocortisona. 


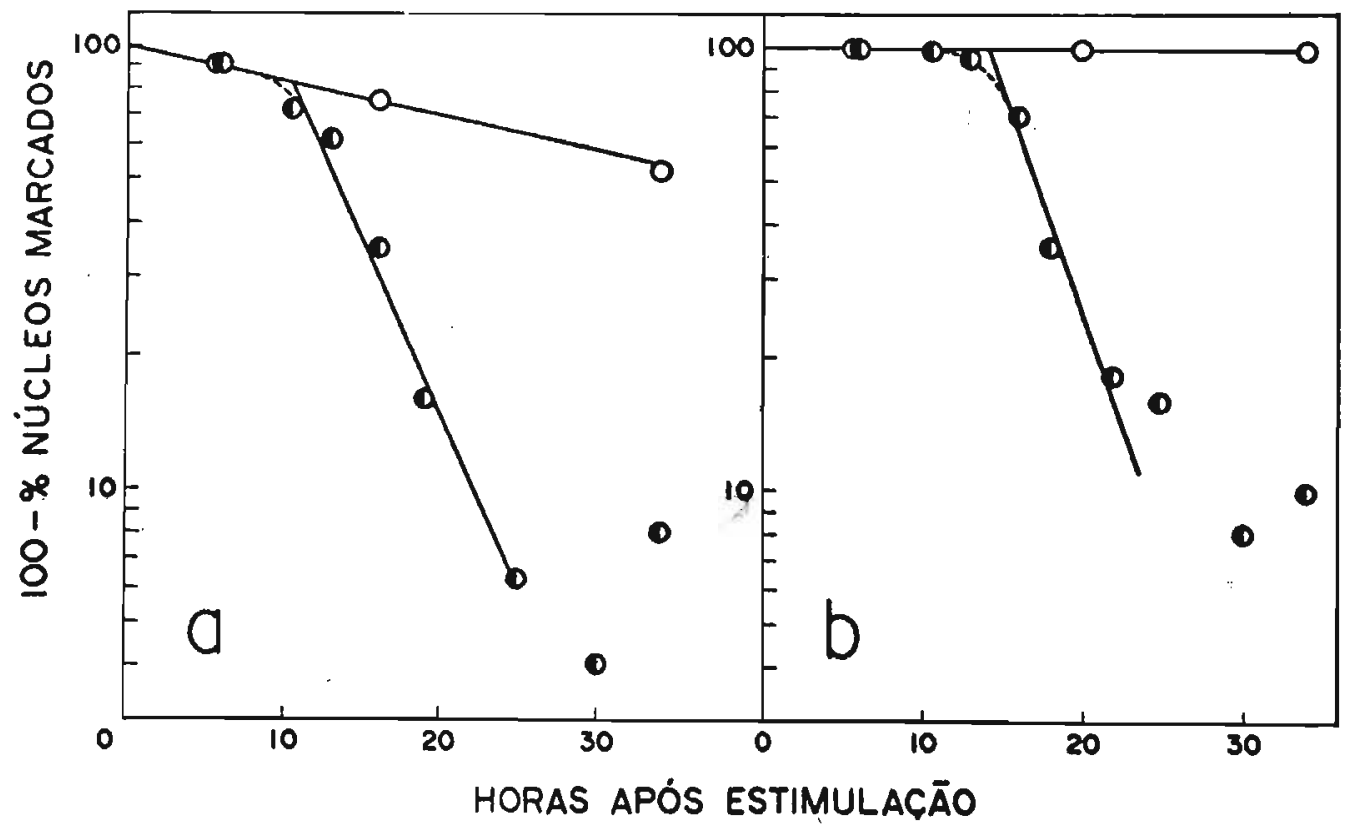

Fig. 34 - Cinética (após reestımulação)da entrada em s por cêlulas STl não tratadas (a) ou tratadás com $300 \mathrm{ng} / \mathrm{ml}$ de hidrocortisona (b) . O-0 0,28 FCS; $\longrightarrow 58$ FCS

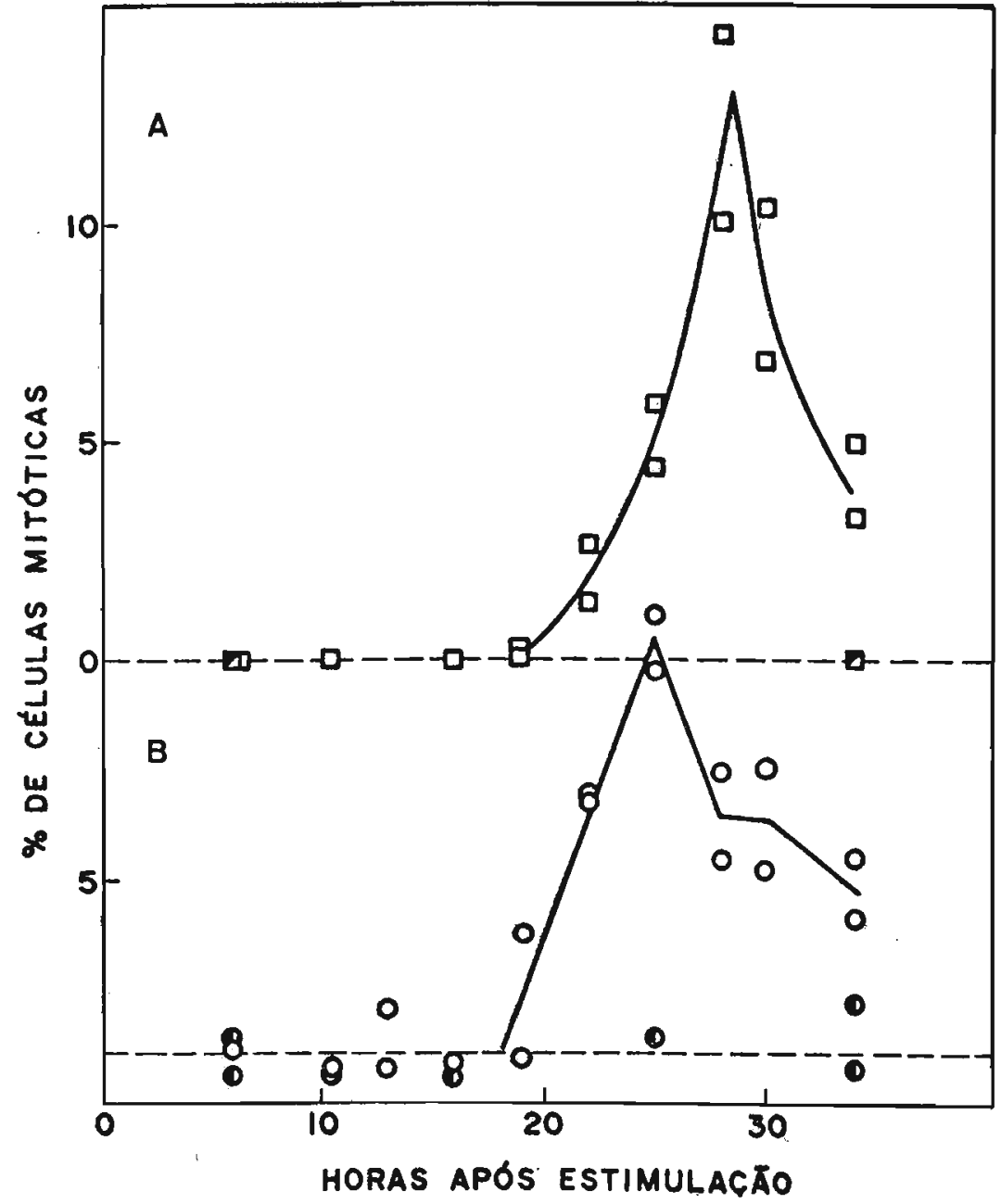

Fig. 35 - Cinética (após reestimulação) da entrada em M por célu u las STl não tratadas (b) ou tratadas com $300 \mathrm{ng} / \mathrm{ml}$ de hidro $=$ cortisona (a). $\Delta-\Delta e^{-} 00,28$ FCS; $\square-\square$ e $0 \longrightarrow 58$ FCS. 


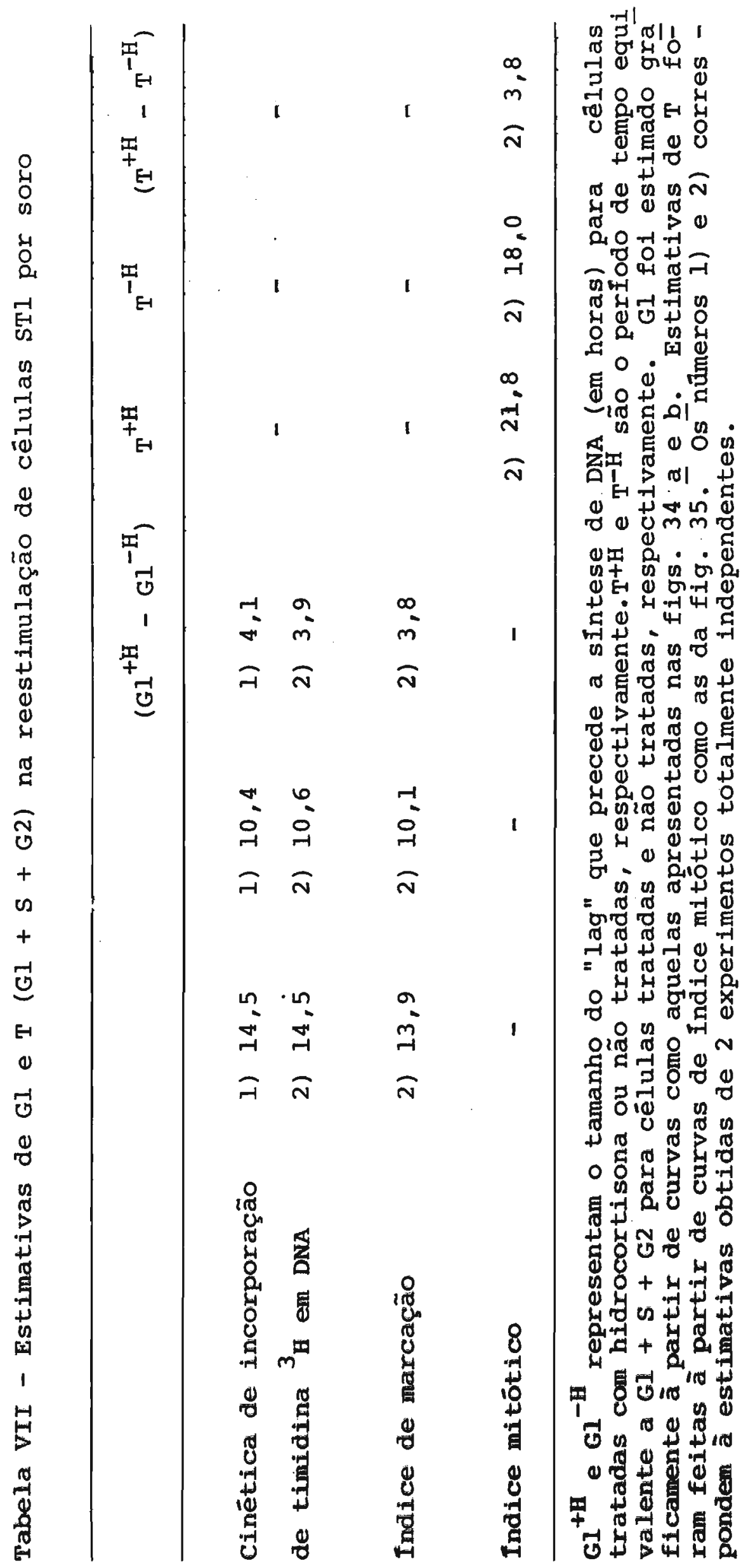


Procurando levar avante a análise deste mecanismo,tor nou-se lógico perguntar se hidrocortisona alterava a respos ta de células STl a fatores de crescimento de natureza conheci da. Assim, a atividade de diversos fatores que estimulam a sintese de DNA da linhagem parental 3T3 fol testada em cêlu las STI, na presença e na ausêncla de hidrocortisona. Um resụ mo dos dados obtidos é apresentado na tabela IV. Verificou-se que apesar de hidrocortisona induzir, em células STl, alta dependência para soro e "inibição de contacto", a célula permane ce sem resposta a EGF, PF, somatomedinas e PGF $2 \alpha$. Somente insulina e albumina bovina são ativas: na ausência de hidrocorti sona a atividade destes fatores è somatória (fig. 36a) e, na presença do hormônio, è sinergística (fig. 36b). A atividade da albumina parece ser devida a um contaminante não dializâ vel, o qual pode ser um fator de crescimento alnda desconhecido.

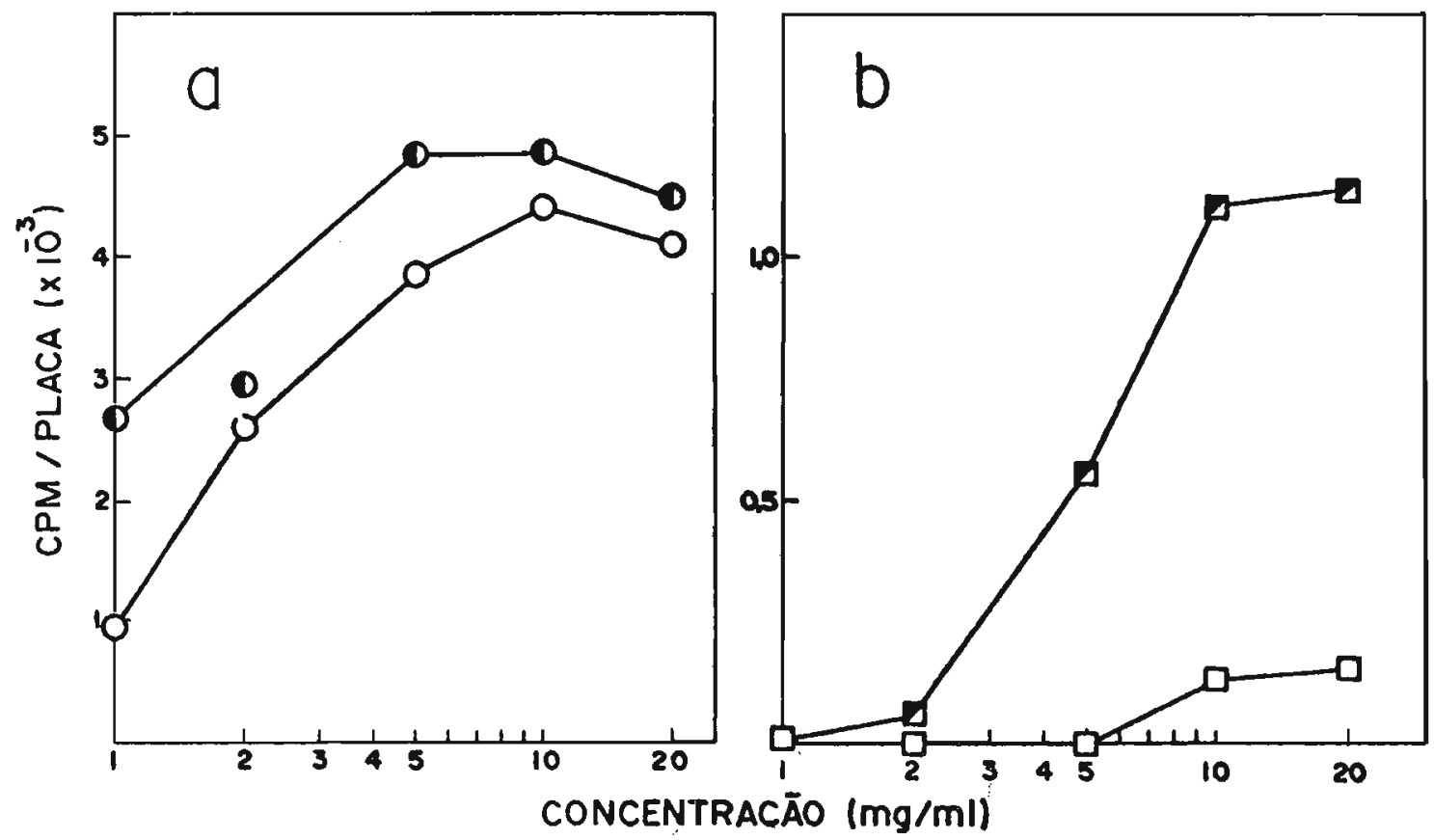

Fig. 36 - Atividade estimulatória de insulina e albumina de soro bovino (BSA) sobre a síntese de DNA de células STl a) na ausên cia de hidrodortisona; b) na presença de hidrocortisona $\left(300^{-}\right.$ $\mathrm{ng} / \mathrm{ml}) \quad 0-0$ e $\square-\square$ BSA; 0 e $-\square$ BSA + Insulina(l $\mu \mathrm{g} / \mathrm{ml})$. 
A atividade de proteases, como tripsina e trombina, na estimulação da sintese de DNA de células STl foi testada. Os resultados foram negativos tanto na ausência como na presença de hidrocortisona.

3.8. Ação de Hidrocortisona Sobre Tumores Induzidos por Células STl

Como vimos, células STl em cultura apresentam uma sé rie de características de células transformadas: empilhamento, alta densidade de saturação, crescimento em suspensão, etc. Testes de tumorogenicidade em camundongos "nude" (item 13 de Métodos) revelaram que, ao contrário da linhagem parental 3T3, células STl são capazes de induzir tumores em animais (fig. 37 e tabela III). A anālise histopatológica destes tumores (item 13 de Métodos) indicou tratar-se de fibrosarcomas com alto grau de anaplasia, alto indice mitótico e com propriedades invasi vas acentuadas (fig. 38). Vimos ainda que, em cultura, hidrocortisona induz, reversivelmente, a transição do estado transformado para o estado normal (crescimento ordenado, baixa densidade de saturação, incapacidade de crescer em suspensão,etc) . A definição destes fenōtipos em cultura é, entretanto, opera cional, não se sabendo se têm correspondência com a fisiologia do animal intacto. Daí ser necessārio efetuar testes "in vivo".

Procuramos investigar, então, se esteróides ativos em cultura eram capazes de inibir o crescimento de tumores induzi dos em animais. Os resultados, que podem ser vistos na tabe la VIII, mostram claramente a inłbição de crescimento tumoral 

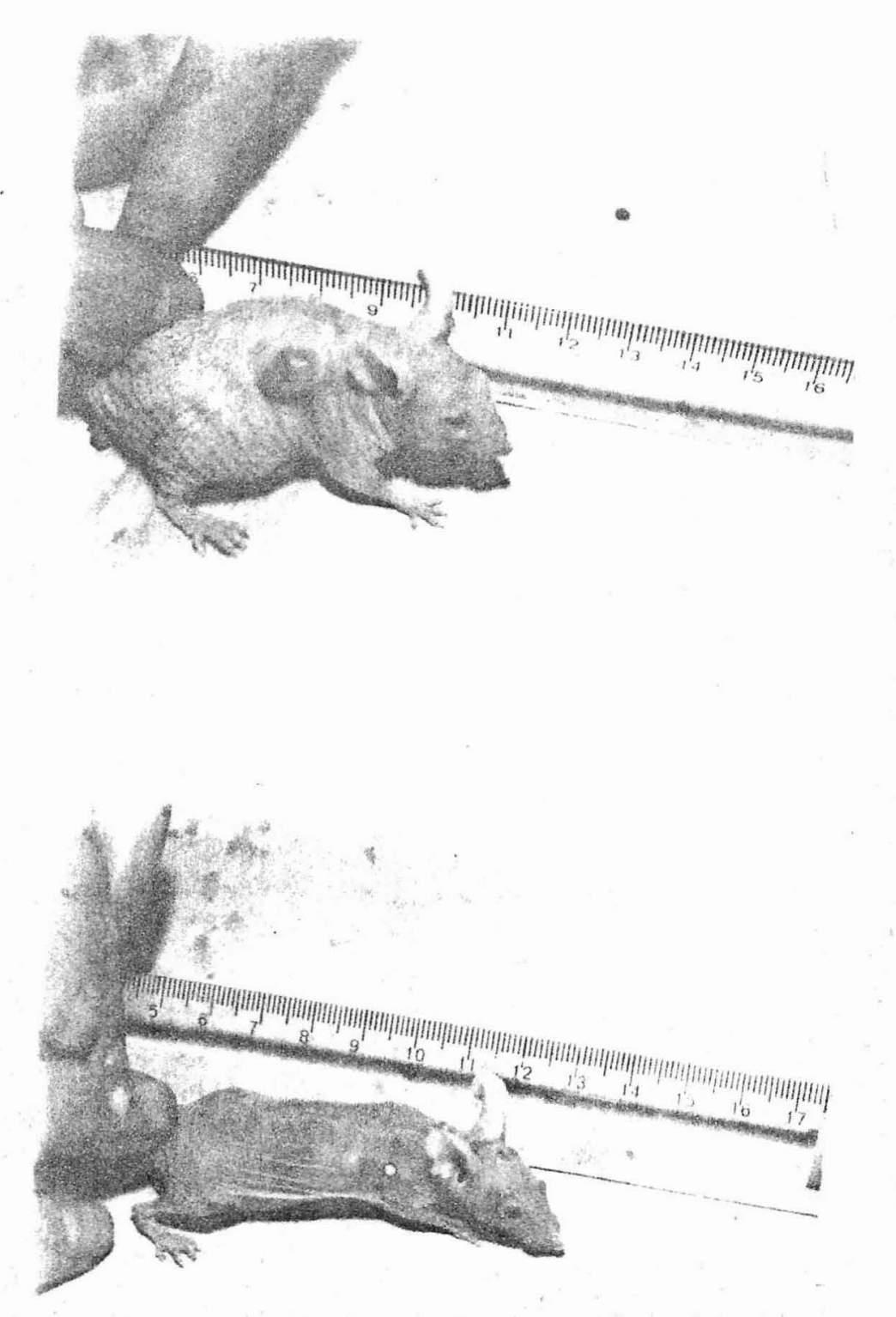

Fig. 37 - Efeito de hidrocortisona no crescimento de tumores induzidos por células STl em camundongos "nude". Aspecto dos animais aos 38 dias de experiência a) Controle (não tratado); b) Injetado periodicamente com dexametasona (10 $\mathrm{\mu g} /$ animal). 

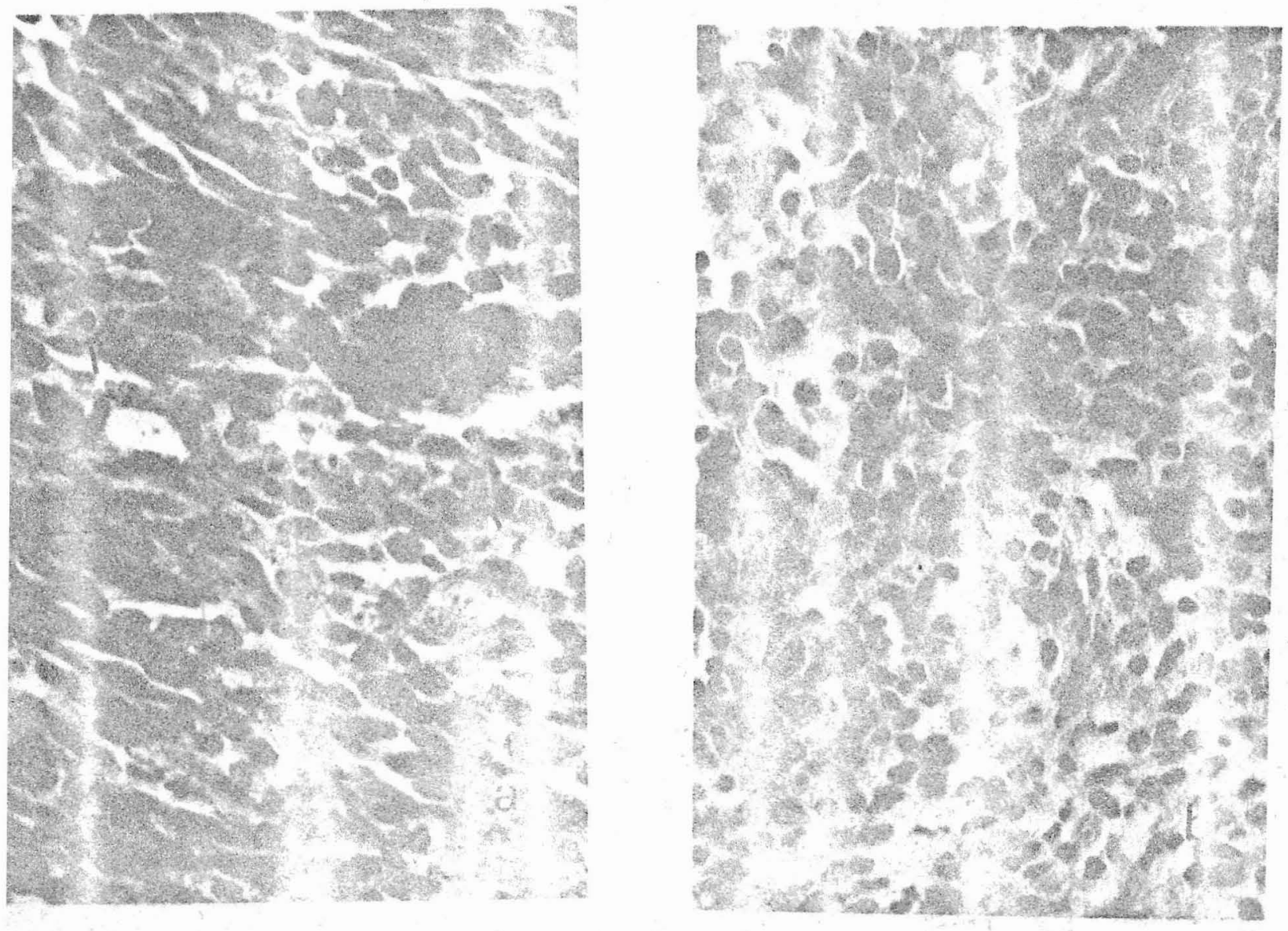

Fig. 38 - Cortes histológicos de tumores induzidos por células STI em camundongos "nude": a) Controle (não tratado); b) injetado periodicamente com dexametasona (10 $\mu \mathrm{g} /$ animal). A seta indica células em divisão. Aumento: $640 \mathrm{x}$. 
Tabela VIII - Efeito de dexametasona no crescimento de tumores induzidos em camundongos "nude" por células STl

\begin{tabular}{cccc}
\hline $\begin{array}{c}\text { Animal } \\
\text { número }\end{array}$ & $\begin{array}{c}\text { Injeções de } \\
\text { dexametasona }\end{array}$ & $\begin{array}{c}\text { Peso do animal } \\
(\mathrm{g})\end{array}$ & $\begin{array}{c}\text { Peso do tumor } \\
\text { (mg) }\end{array}$ \\
\hline 1 & - & 22,1 & 194 \\
4 & - & 23,7 & 202 \\
5 & - & 20,7 & 242 \\
6 & - & 18,5 & 86 \\
7 & + & 15,3 & 22 \\
\hline
\end{tabular}

7 animais de 4 semanas foram inoculados com $1,5 \times 10^{6}$ células cada um. AOs 20 dias todos os animais apresentavam tumores pal páveis (de $0,5-1,0 \mathrm{~cm}$ ). Neste ponto alguns animais passaram $\vec{a}$ receber injeções subcutâneas de dexametasona $110 \mathrm{\mu g} / \mathrm{an} i \mathrm{mal}$ cada 2 ou 3 dias). 18 dias depois os antmais foram sacrificados a os tumores dissecados. Animal no 3 morreu antes do término da experiência.

provocado por dexametasona. Além disso a anālise histopatológica revelou crescimento bloqueado (virtual ausência de mitoses) e um grau muito menor de malignidade (fig. 38). Estes resultados são encorajadores pois indicam que o hormônio é ativo tambēm "in vivo".

3.9. Níveis Intracelulares de cAMP em Células ST1

Evidentemente estavamos interessados em obter informa ções sobre o mecanismo de ação da hidrocortisona ao nível bioquímico. Como cAMP tem sido apontado como mediador importante 
na regulação do crescimento celular (SHEPPARD \& BANNAL, 1974)pạ receu-nos razoāvel investigar se o hormônio induzia altera ções nos niveis intracelulares de cAMP em células STl.

Medidas de CAMP foram feitas pelo método de GILMAN (1970). Células STI crescendo exponencialmente em meio contendo 5\% de soro apresentam 9,5 $( \pm 0,5)$ pmoles de CAMP por $\mathrm{mg}$ de proteína. A adição de hidrocortisona a culturas neste estägio não alterou significativamente o nível de cAMP. Já o ca renciamento das cêlulas por 24 horas em 0,28 de soro, levou a um aumento do nível de CAMP para $20,5( \pm 0,5)$ pmoles/mg de proteína. Na verdade a redução do soro no meio de cultura leva a um rápido aumento de cAMP. Assim, 1 hora após a transferên cia de células de meio contendo $5 \%$ de soro para meio sem soro, - nivel de CAMP atinge 26,0 pmoles/mg de proteína. Este aumento do CAMP intracelular de células STl, em resposta à redução do soro no meio de cultura, tem sido encontrado entre todas as linhagens de fibroblastos estudadas, devendo ser, portanto, uma propriedade comum. Quando hidrocortisona esteve presente duran te o carenciamento ( 24 horas em $0,2 \%$ de soro), o nível de cAMP foi o mesmo que aquele encontrado na ausência do hormônio, isto é, 21,0 pmoles/mg de proteina. Portanto não conseguimos detectar nenhum efeito de hidrocortisona sobre os níveis intracelula res de cAMP em células STl.

3.10. Alterações Morfolögicas de Células STl: Efeito de Soro, CAMP e Hidrocortisona

A ação de hidrocortisona sobre cēlulas STl è do tipo pleiotrópico; logo era importante fazer uma inspeção cuidadosa 
dos efeitos do hormônio sobre a célula, na tentativa de encontrar indicações de seu efelto primärto.

Como já foi mencionado, hidrocortisona torna ạ cêlulas,STl mals achatadas e aumenta sua adesão tanto à superficie da placa de cultura como às cêlulas vizinhas. Estas observa ções indicam que estão ocorrendo alterações na superficle celü lar. Na verdade STl apresenta alterações morfológicas incomuns para flbroblastos, alterações estas que dependem do complexo membrana-citoesqueleto e que fornecem sugestões interessantes sobre o possivel efeito primärio de hidrocortisona.

Um aspecto multo interessante de cèlulas STl è a dramãtıca alteração morfológica que sofre quando o soro é retirado do me10. Assim, quando transferidas para melo sem soro, 100\% das células se arredondam em apenás 30 minutos adquirindo o aspecto da flg. 39.

Este fenômeno de arredondamento não é bloqueado pọ inibidores de sintese de proteina ou RNA. Citocalasina B tambêm não interfere com o fenômeno mas colchıcina bloqueia completamente $o$ arredondamento, mostrando que se trata de processo dependente de microtúbulos.

Concentração de 0,28 de sọo é suficiente para evitar - arredondamento das cêlulas. Albumina bovina substitui parcialmente o soro, porēm os diversos hormônios ou fatores pro teicos testados (1nsulina, ACTH, somatomedinas e PF) ou comb1nações deles, não tiveram qualquer efeito sobre $\circ$ arredondamen to provocado pela retirada de soro. 

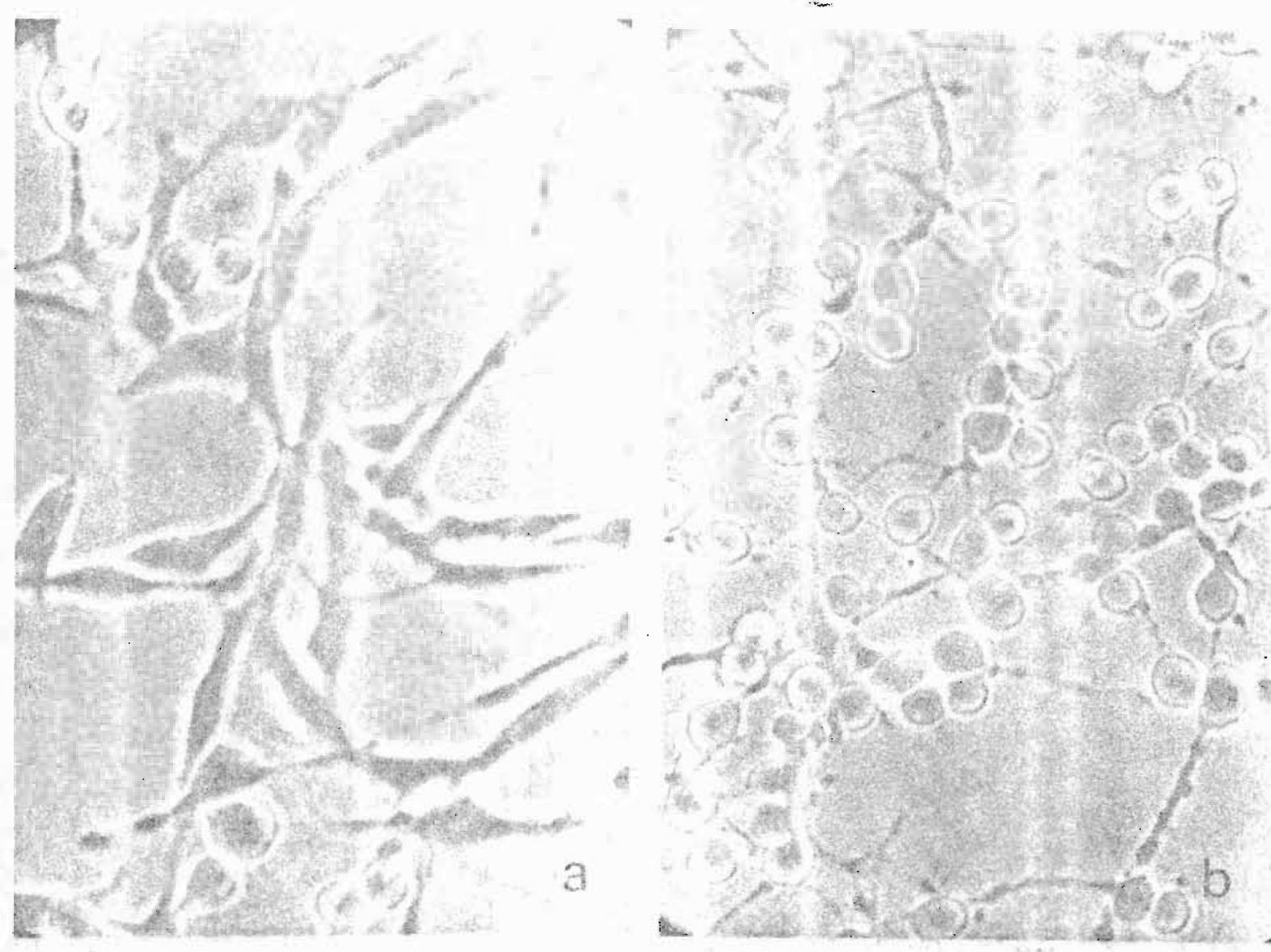

tou

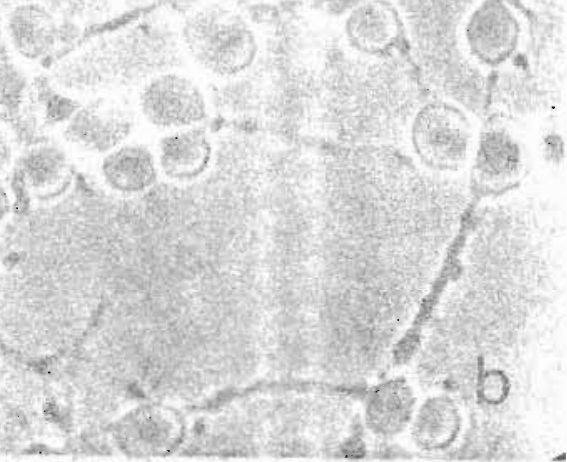

Fig. 39 - Alteração morfológica provocada pela retirada do soro ou por adição de cAMP a culturas de células STl. a) contro le (não tratado); b) tratado por 30 minutos em meio sem soro ou 30 minutos em meio contendo $5 \%$ de soro $+100 \mathrm{mM}$ CAMP. Aumento: $150 \mathrm{x}$. 
Durante estas experiências uma observação interessante foi feita: verificou-se que a adição de cAMP ao melo de cul tura contendo altas concentrações de soro causa $100 \%$ de arredondamento (fig. 39) mimetizando o efeito da retirada do soro. Tanto CAMP como dibutiril-cAMP provocam o arredondamento na presença de 5 de soro, porēm 5' AMP ou cGMP não têm qualquer efeito. Esta observação sugere que CAMP desencadearia o arredondamento agindo a nível de micfotúbulos.

Como mostra a fig. 40a hidrocortisona não impede que - arredondamento provocado pela retirada do soro ocorra mas acelera o retorno das células ao estado natural (achatadas).Na ausência de hidrocortisona, albumina, em baixas concentrações $(0,2 \mathrm{mg} / \mathrm{m} 1)$ não tem efeito sobre $\circ$ arredondamento (fig. $40 \underline{b}$ ) po rēm em concentrações de 1 e $5 \mathrm{mg} / \mathrm{ml}$ o arredondamento é retarda do (1008 atingido apenas depois de 5 horas), como mostram as figs. 40 c e d. Na presença de hidrocortisona, porēm, albumina (l e $5 \mathrm{mg} / \mathrm{ml}$ ) inibe totalmente 0 arredondamento.

Na fig. 41 encontram-se as cinéticas do processo de arredondamento provocado por diversas concentrações de CAMP na presença e na ausência de hidrocortisona. Foi possível verificar que este esteróide bloqueia o arredondamento provocado por CAMP. E mals ainda: este efelto bloqueador $\bar{e}$ dependente da sintese de proteina, uma vez que cicloheximida impede to talmente a ação inibitória de hidrocortisona, conforme mostra a fig. 42 . 

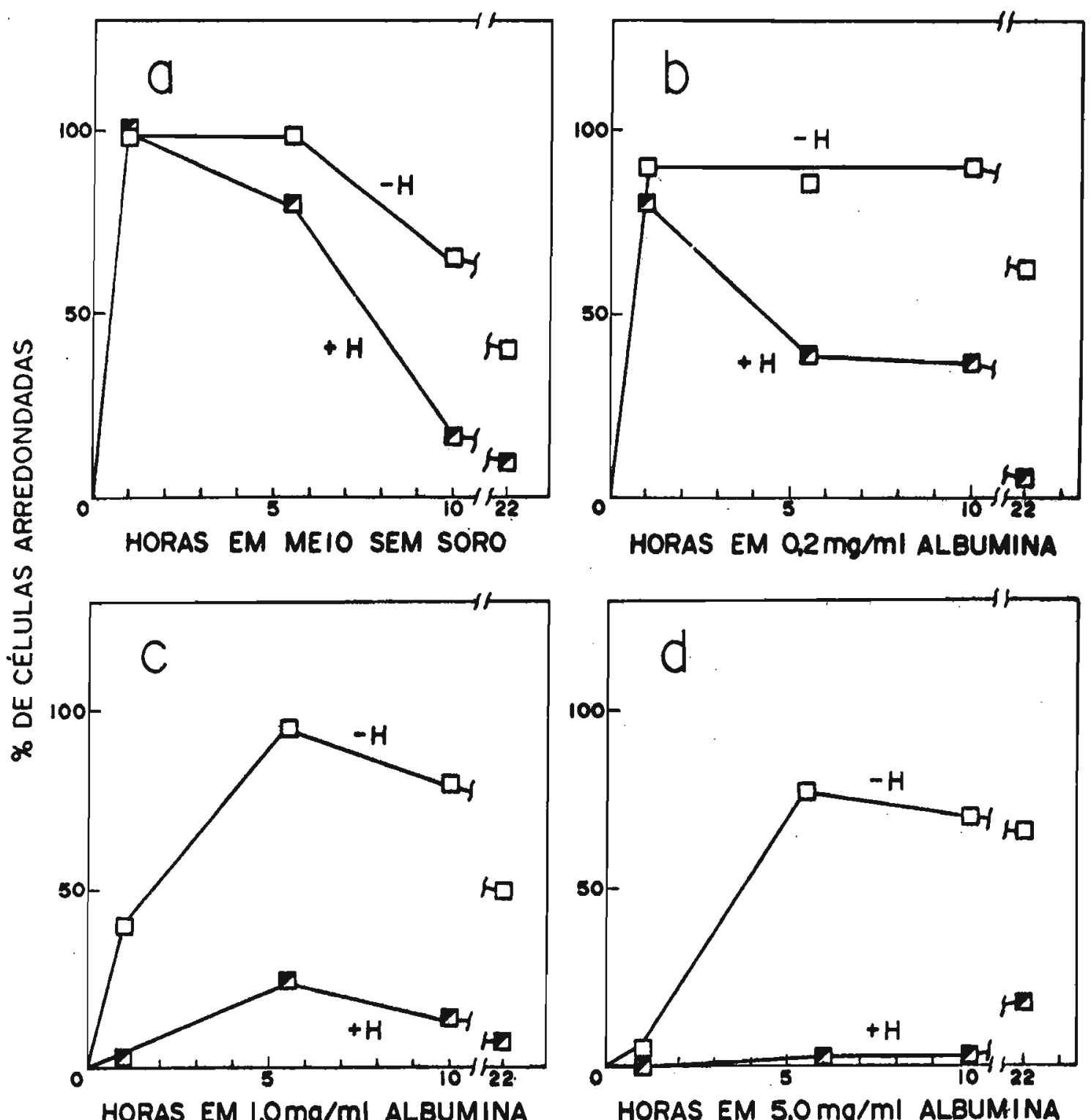

HORAS EM $5,0 \mathrm{mg} / \mathrm{ml}$ ALBUMINA

Fig. 40 - Cinética do processo de arredondamento em: a) melo sem soro (MSS); b) MSS $+0,2 \mathrm{mg} / \mathrm{ml}$ albumina; c) MSS + 1,0 $\mathrm{mg} / \mathrm{ml}$ albumina; d) MSS $+5,0 \mathrm{mg} / \mathrm{ml}$ albumina. $\square$ na ausên cia de hidrocortisona; t- 4 na presença de hidrocortisona (300 $\mathrm{ng} / \mathrm{ml})$.

Neste ponto tornou-se interessante verificar se estas alterações morfológlcas podiam 1nterferir com a reestimu lação da sintese de DNA en cêlulas carencladas para soro.Cul turas carenciadas foram reestimuladas, por adıção de soro, e, apbs diferentes Intervalos de tempo transferidas para mato 


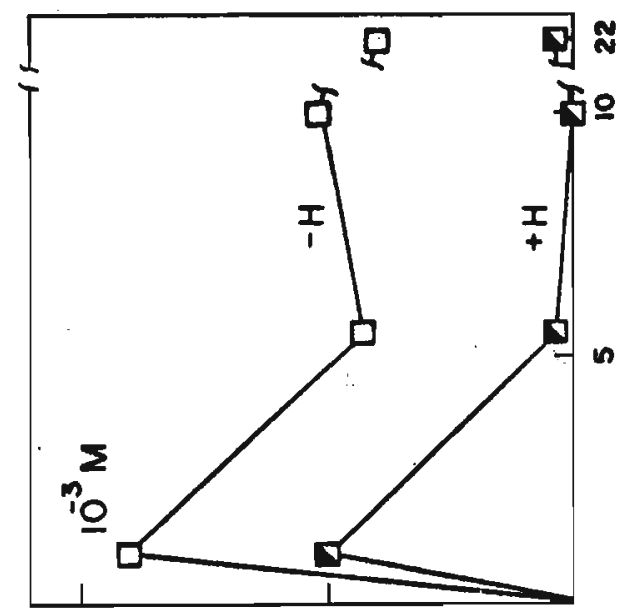

‘َّٔ

80

02

냉

o 8

o

\%

0․ㅛ

(1)

is

$\stackrel{5}{4}$ б

다

邑

द果

究 ?
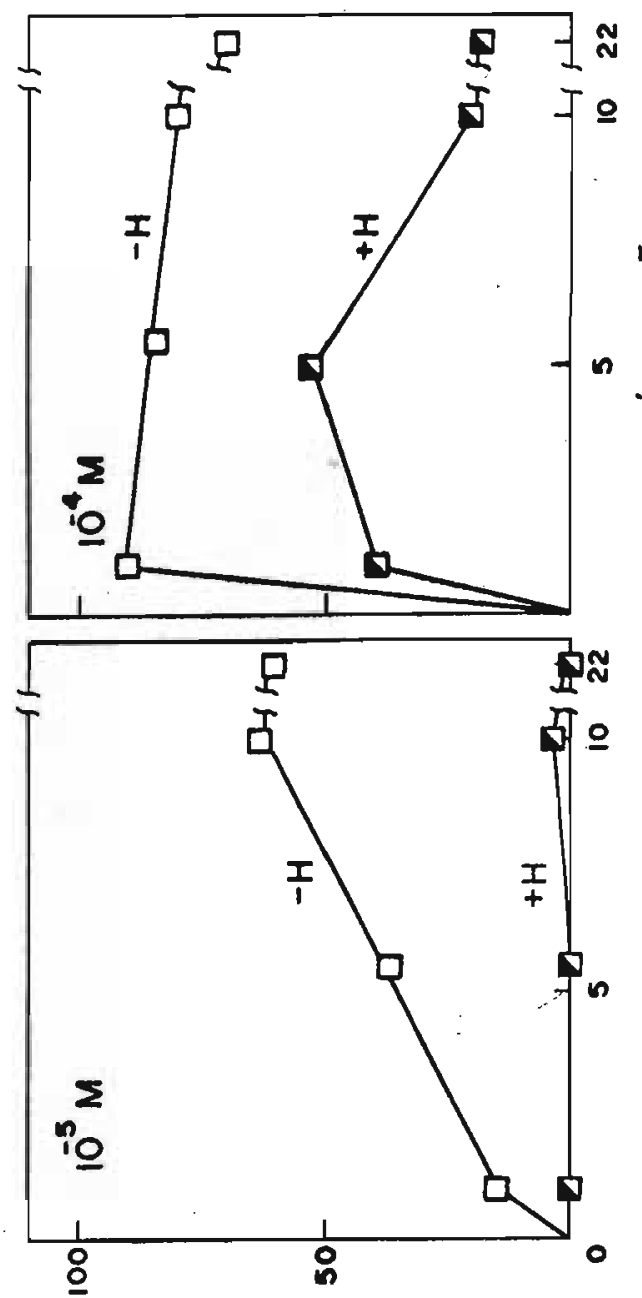

o

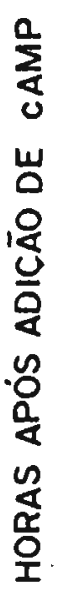

1ำ

苂

$\rightarrow$

ᄋำ

क्ष है

ริ छ

ช 0

영요

¿

410

ชิ

(1)

ฮิำ

o..

证

din 4

U

다어

م

..

ชै요

质

(1)

ज 4

नुत्व

I g 茟

10

$-10$

劣

$\dot{0}$

की

在 


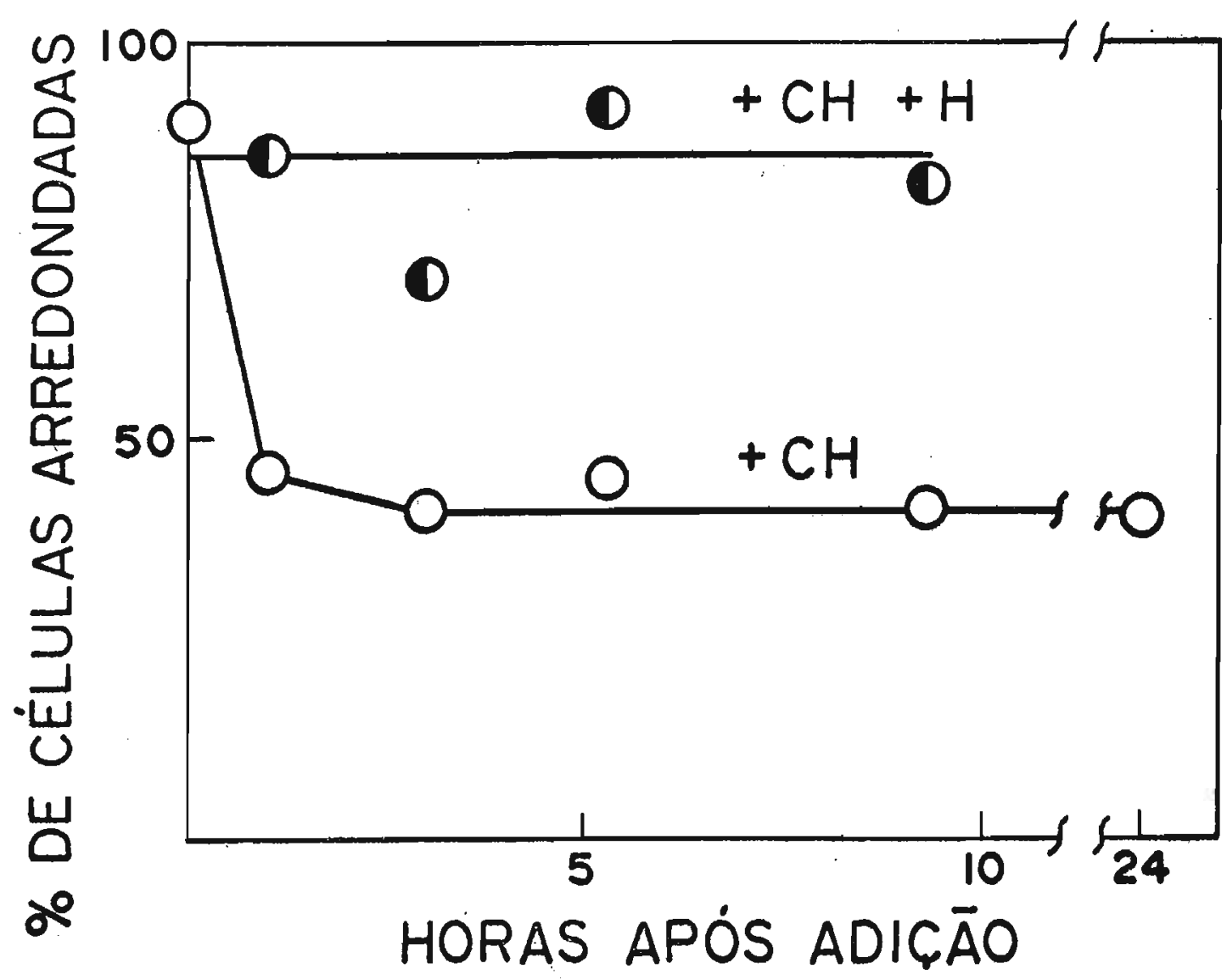

Fig. 42 - Efeito de hidrocortisona e cicloheximida no arredon damento provocado por CAMP em células STl. Hidrocortisonā $(300 \mathrm{ng} / \mathrm{ml})$ e cicloheximida $(1,5 \mathrm{mM})$ adicionados ém $t=0$. Nos tempos indicados cAMP $\left(10^{-4} \mathrm{M}\right)$ foi adicionado $e$ a 8 de células arredondadas determinada 1 hora depois.

sem soro. Os resultados de medidas da sintese de DNA, encontram-se na fig. 43. Detalhes do protocolo para este tipo de experiência podem ser vistos na legenda da mesma figura. Estes resultados indicam que se a transferência para meio sem soro for felta até 3 horas de reestimulação (células no inIcio de GI) a reestimulação não ocorre. Se a transferêncla for feita 14 horas após a adıção de soro, a reestimulação da sintese de DNA ocorre normalmente. E importante lembrar que 14 horas apōs a adıção de soro a maior parte das células jã está, no minimo, comprometida $\left(G I^{C}\right)$ com o processo de sintese de 
de DNA (e uma boa parte já está em $S$ ). Estes resultados indicam, portanto, que o arredondamento não interfere com o proces so de sintese de DNA se este já tiver sido desencadeado ou com - seu desencadeamento em células já comprometidas. Deve-se lem brar que a reestimulação de células carenciadas com soro durante 3 horas, seguida de transferência para 0,2\% de soro, leva a uma eficiente estimulação da sintese de DNA.

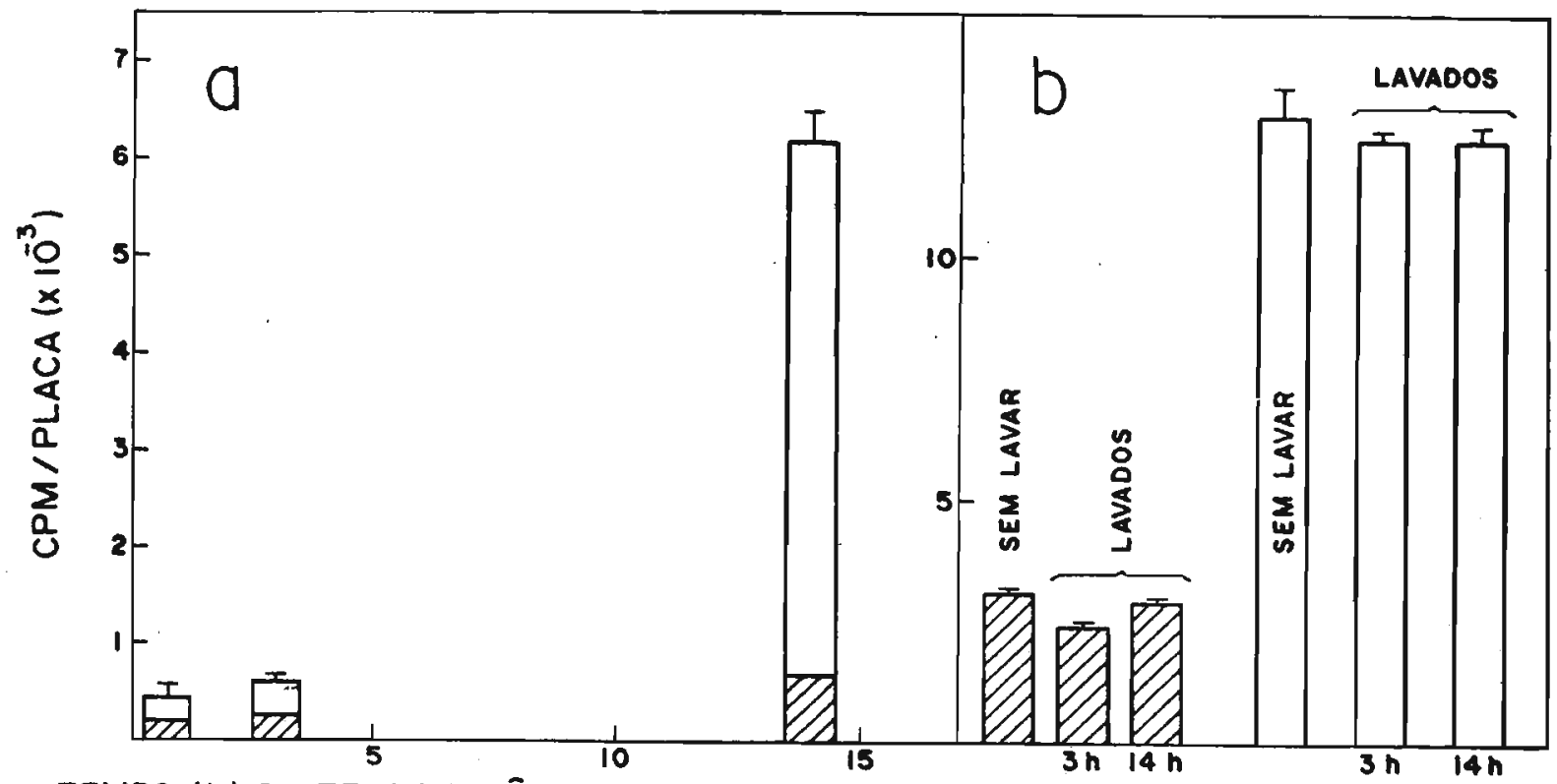

TEMPO (h) DA TRANSFERÊNCIA PARA MEIO SEM SORO

Fig. 43 - Efeito de arredondamento sobre a reestimulação de cê lulas STl carenciadas para soro. a) Adição de soro (5: FCS) em $t=0$. Nos tempos indicados $(45 \mathrm{~min}, 3 \mathrm{~h}, 14 \mathrm{~h})$ culturas foram lavadas e transferidas para melo sem soro. Incorporação de timidina $3_{\mathrm{H}}$ em DNA, entre 15 e 24 horas. Culturas não re estimuladas transferidas para meio sem soro; culturas reestimuladas transferidas para melo sem soro.b)Controles: sem lavar ou lavadas porém transferidas para meio contendo 0,28 de soro $(\mathbb{Z Z})$ ou 58 de soro ( $\square)$.

Numa tentativa de conclusão final podemos dizer que as observações relatadas nesta seção sugerem que hidrocortisona pode estar causando todos os seus efeitos através da indú ção de uma alteração estrutural (dependente da sintese de prote na) ao nível do sistema superfície celular-membrana-c1toesque 
4. ANALISE DO COMPORTAMENTO DE CELULAS ADRENAIS Y-I

\subsection{Efeito de Soro}

Células adrenais $\mathrm{Y}-1$ crescendo exponencialmente, quando submetidas à remoção total ou parcial do soro, respondem com uma diminuição da sintese de DNA (fig. 44). No entanto um nível significativo de síntese de DNA permanece mesmo após

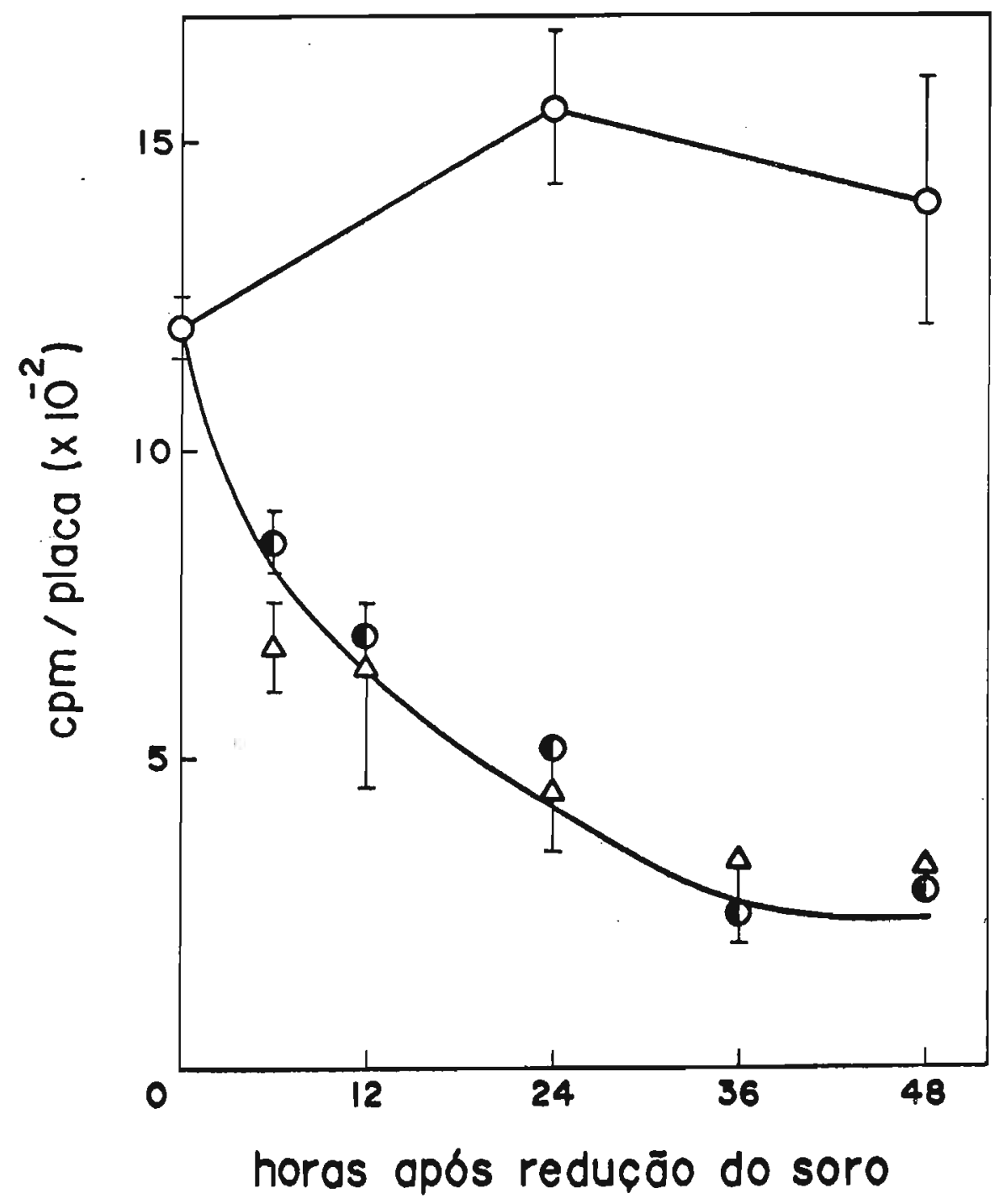

Fig. 44 - Cinētica do efelto da redução do soro sobre a sintese de DNA em células $Y-1$. Pulsos de timidina $3_{\mathrm{H}}$ de 30 minutos. De talhes do protocolo em Mêtodos. O-O Culturas mantidas em $5 \overline{8}$ de soro (FCS); $\rightarrow$ culturas transferidas em $t=0$ para meio contendo 0,28 FCS; $\Delta-\Delta$ culturas transferidas em $t=0$ para me1o sem soro. 
Fig. 45 - Alteração morfológica provocada por ACTH e CAMP em células Y-l. a) Controle (não tratadas); b) após 5 horas em $\operatorname{ACTH}(0,6 \mathrm{U} / \mathrm{ml}) ; \mathrm{c})$ apór 5 horas em CAMP $\left(10^{-3} \mathrm{M}\right)$; d) aspecto da variante $A R-1$ (na presença ou na ausência de $A C T H$ 0,6 $\mathrm{U} / \mathrm{ml}$ ). Aumento: 150x. 

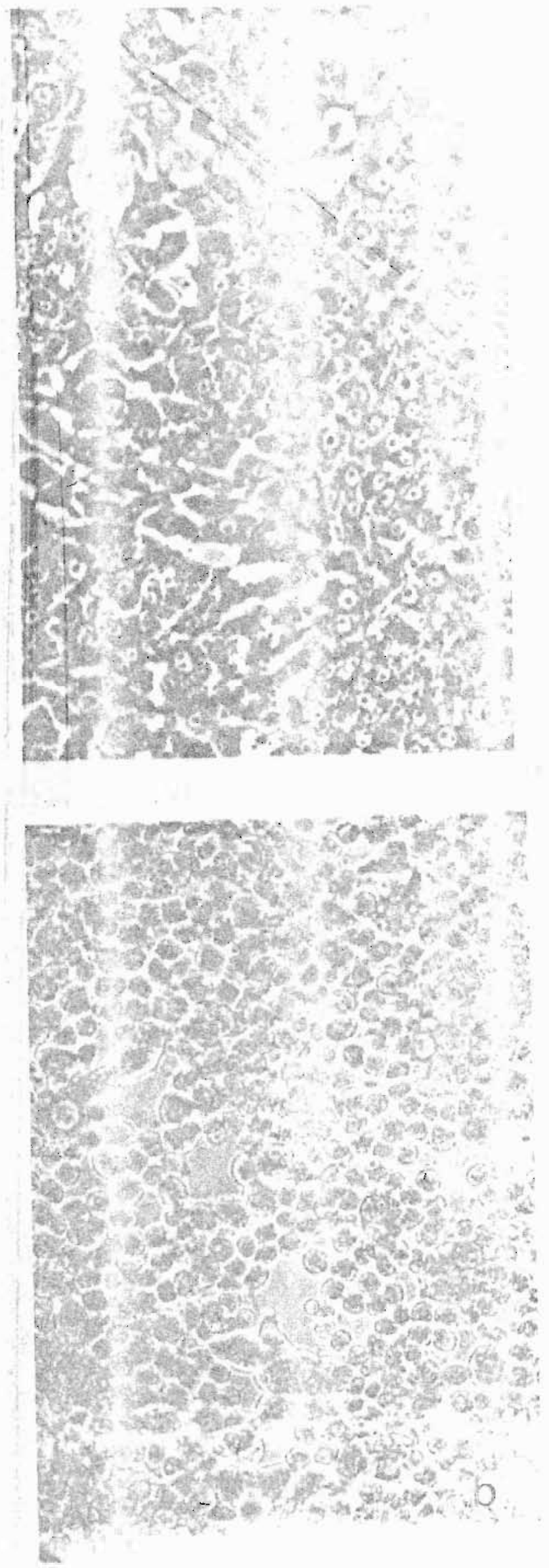
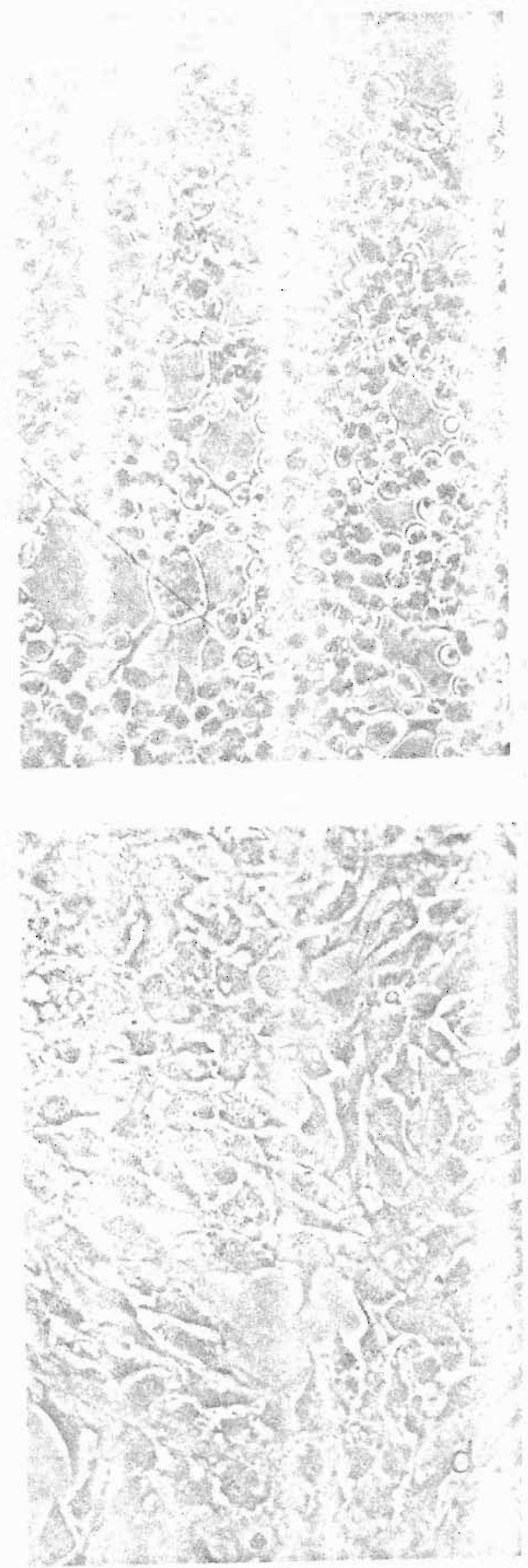
48 horas na total ausência de soro, indicando que as cêlulas en tram num estado de repouso parcial ou relativo. Estas células podem ser reestimuladas e na fig. 45 encontra-se resultados da resposta à diferentes concentrações de soro quanto à síntese de DNA. Esta resposta foi proporcional ã concentração de soro sendo máxima em $10 \%$ de soro (estimulação de 7 vezes). o grau de estimulação de células Y-l com alta concentração de soro foi variável: comumente conseguia-se 4 a 10 vezes, porém valores de 30-40 vezes foram encontrados. Esta variabilidade é devida a diferentes niveis de sintese residual de DNA antes da reestimulação.

4.2. Efeito de Hormônios e Fatores de Crescimento

O efeito de uma série de hormônios e fatores de cresci mento na sintese de DNA de células Y-l foi testado, conforme descrito no item 18 de Métodos. Hidrocortisona (100-300 ng/ml), preparações impuras de TSH (atē $5 \mu \mathrm{g} / \mathrm{ml}$ ), FSH (atē $5 \mu \mathrm{g} / \mathrm{ml}$ ) e $\mathrm{GH}$ até $5 \mathrm{\mu g} / \mathrm{ml}$ ) foram totalmente inativos. Preparações de LH, por outro lado, foram estimulatōrias à $0,5 \mu \mathrm{g} / \mathrm{ml}$ e inibitōrias à $2 \mu \mathrm{g} / \mathrm{ml}$ (fig. 10) indicando a presença de substâncias de efei to antagônico nestas preparaçōes. Como mostra a fig. 10, a pre paração de PF é 200 vezes mais ativa que extrato cru de pituitạ ria, 10-20 vezes mais ativa que preparações impuras de LH e, alēm disso, não contém inibidores da síntese de DNA. E impor tante ressaltar que hidrocortisona e insulina não alteram o efeito estimulatório dado por PF. Assim, o efeito sinegístico de-hidrocortisona sobre a atividade de $\mathrm{PF}$, observado com fibroblasto 3T3, não ocorre com células adrenais $\mathrm{Y}-1$. 
4.3. Efeito de ACTH e CAMP

o único hormônio clássico que apresentou efeito sobre a sintese de DNA destas células foi ACTH. Conforme ilustrado na fig. 45 este hormônio provoca também uma resposta morfologica dramática de arredondamento em cẻlulas $\mathrm{Y}-1$ e este efeito pode ser mimetizado por adição de cAMP ao meio. A cinética do proces so de arredondamento provocado por diferentes concentrações de $\mathrm{ACTH}$ em 2 concentrações diferentes de soro, pode ser vista na fig. 46. E possível notar que: a) resposta máxima é conseguida após 5 horas de exposição ao hormônio; b) concentrações ma1s altas de ACTH são necessárias na presença de $10 \%$ de soro do que em $0,2 \%$ de soro; c) o efeito tende a ser reversivel na presença de concentrações subōtimas de ACTH.

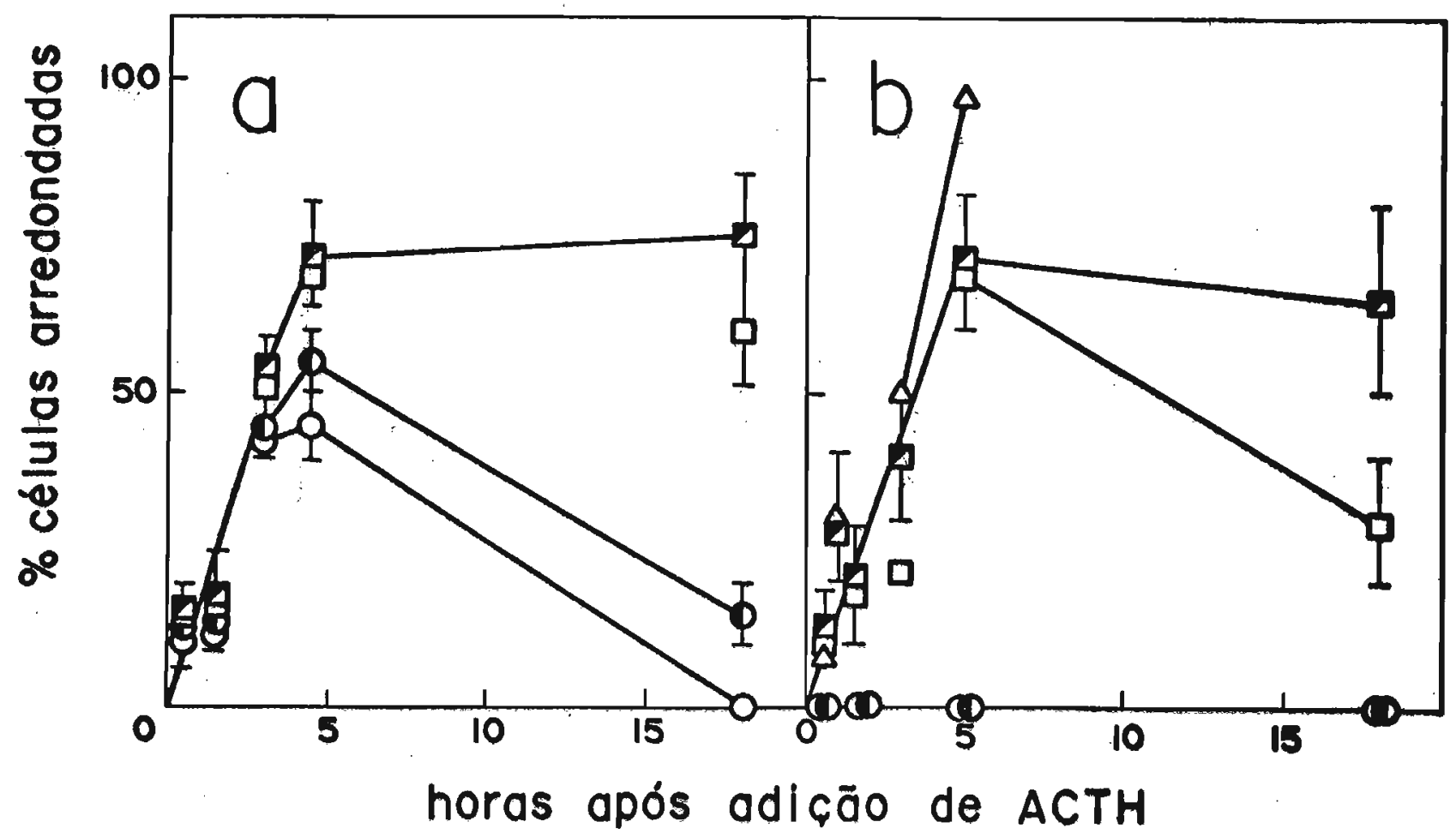

Fig. 46 - Cinética do processo de arredondamento provocado por diferentes concentrações de ACTH em meio contendo 0,28 FCS (a) ou $10 \%$ FCS (b). Concentrações de ACTH em mu: $0-0,0,1 ; 0$ 10; $D$ - $100 ; 00 ; \Delta-\Delta 1200$, 
O efeito de ACTH sobre a sintese de DNA de células Y-l pode ser visto nas curvas de dose apresentadas na fig. 47. Este hormônio teve atividade inibitória tanto em baixa como em alta concentração de soro. Em $0,2 \%$ de soro, $0,1 \mathrm{mU} / \mathrm{ml}$ causou $25 \%$ de inibição e $50 \%$ de inibição foi atingida com $3 \mathrm{mU} / \mathrm{ml}$. Em altas concentrações de soro foram necessaarias concentrações mais altas de $\mathrm{ACTH}$; assim, em $10 \%$ de soro, $10 \mathrm{mU} / \mathrm{ml}$ causaram apenas $10 \%$ de inibição e $50 \%$ de inibição exigiu $70 \mathrm{mU} / \mathrm{ml}$. Nas mes mas condições, ACTH não teve efeito algum sobre a sintese de DNA de células 3 T3 ou STl.

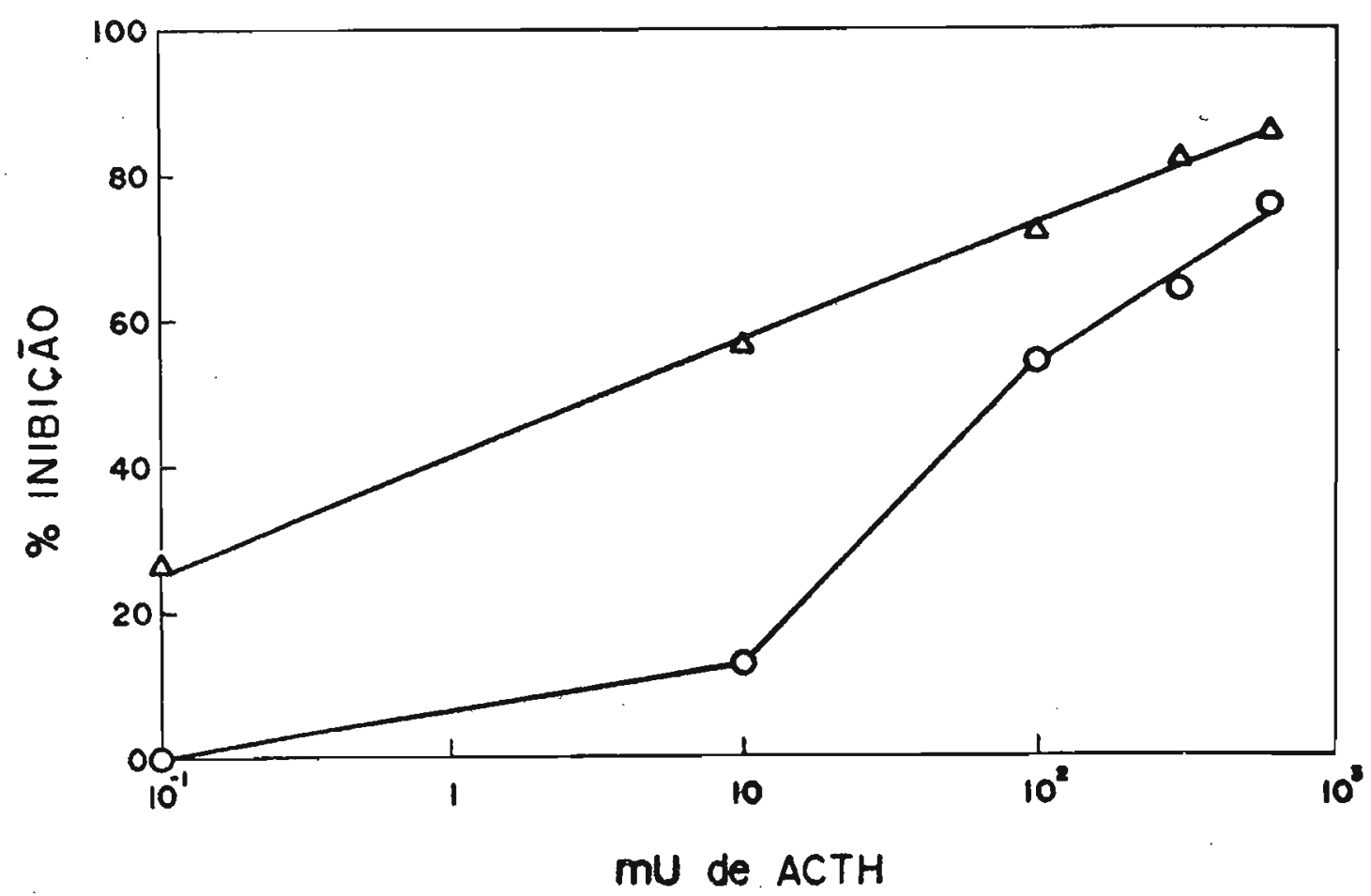

Fig. 47 - Curvas de dose de ACTH para células Y-l na presença de $0,2 \%$ FCS $(\Delta-\Delta)$ e $5 \%$ FCS $(0-0)$. 
O efeito inibitōrio de ACTH sobre células Y-l fol pri meiro observado por MASUI \& GARREN (1971) os quais postularam que a ação deste hormônio era mediada por cAMP. Podemos verificar que CAMP e dibutiril cAMP inibem a síntese de DNA em concentrações maiores que $10^{-3} \mathrm{M}\left(10^{-4} \mathrm{M}\right.$ tendo efeito muito reduzido e $10^{-5} \mathrm{M}$ não tendo qualquer efeitol enquanto cGMP não teve qualquer efeito (estimulatório ou inibitōrio).

4.4. Cinética da Reestimulação de Síntese de DNA

A resposta de células $Y-1$ a soro e PF fol analisada em experiências cinéticas. Os resultados, apresentados na fig. 48 a e $\underline{b}$ indicam que: a) células $\mathrm{Y}-1$ em repouso respondem à adição de soro ou PF com uma onda de sintese de DNA a qual ocorre apenas após um "lag" (GI); b) este "lag" è o mesmo para células estimuladas com soro ou com PF (e igual a 11 horas); c) Gl é idêntico ainda para células estimuladas com diferentes concentrações de soro; d) a velocidade de entrada em $S$ é proporcional à concentração de soro e PF; e) diferenças na magnitude de resposta são devidas a diferente número de cēlulas entrando em $\mathrm{S}$ (fig. $48 \mathrm{~b}$ ). Portanto respostas de magni tudes diferentes não são devidas à alteração no tamanho de Gl mas sim à diferente proporção de células entrando em $\mathbf{s}$.

\subsection{Ação de ACTH no cliclo celular}

A ação inibitória de ACTH sobre a estimulação dada por PF fol investigada usando o protocolo descrito na legenda da fig. 49. Os resultados, apresentados nesta figura,mostram 


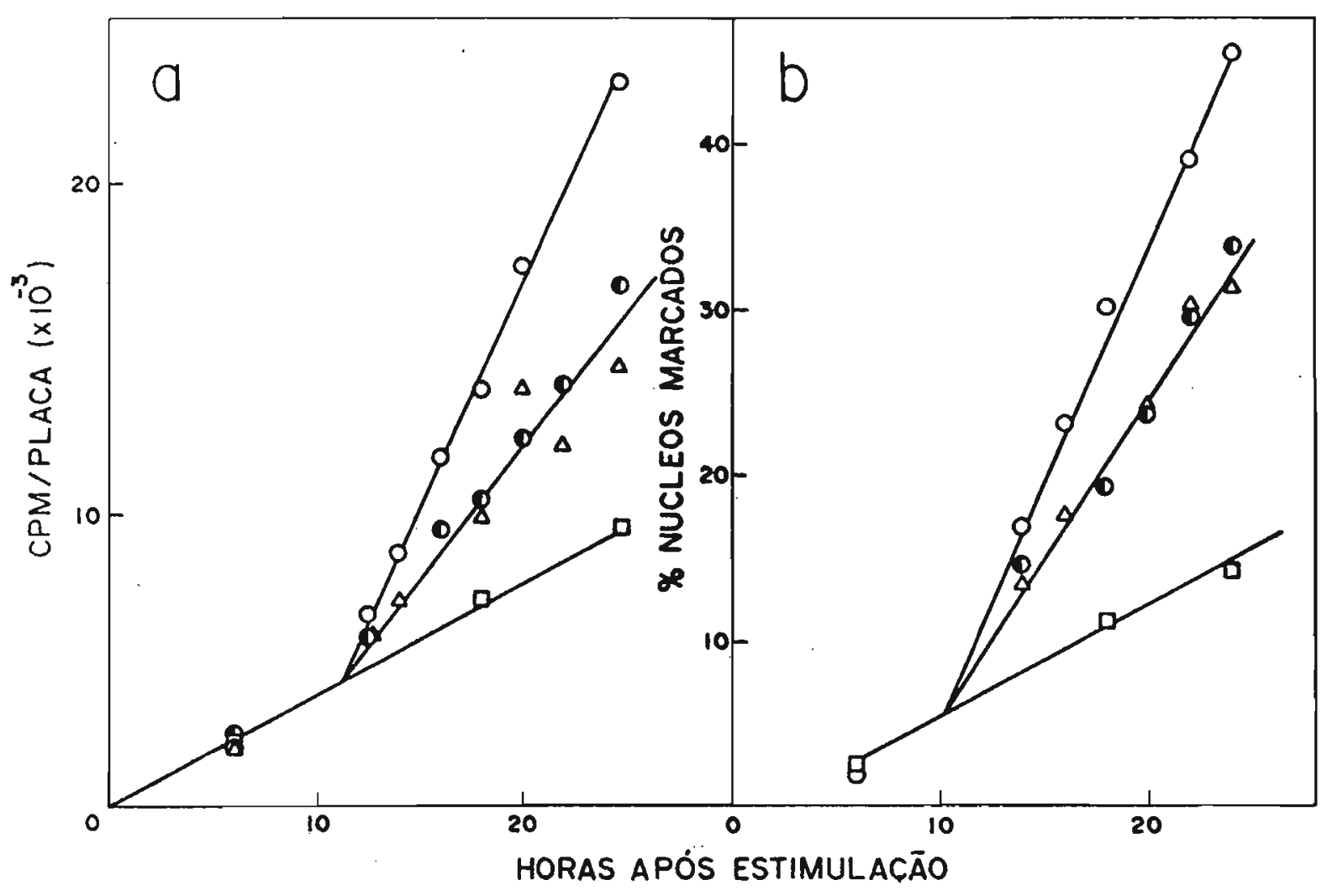

Fig. 48 - Cinētica de reestimulação da síntese de DNA por soro e PF em células $\mathrm{Y}-1$ carenciadas para soro. a) Incorporação de timidina $3_{\mathrm{H}}$ em DNA; b) índice de marcação $\square \square \square$ Controle (nạo estimulado); $0-05 \% \mathrm{FCS} ; 0 \longrightarrow 0,758 \mathrm{FCS} ; \Delta \longrightarrow \Delta 1 \mu \mathrm{g} / \mathrm{ml} \mathrm{PF}$.

que ACTH adicionado 2 horas antes ou até 2 horas depois de PF bloqueia totalmente a estimulação dada por PF. A adição de ACTH de 6. horas em diante, porēm, permitiu a expressão da atividade estimulatōria de PF com magnitudes crescentes. Estes re sultados sugerem que apôs estimulação com PF as células que progridem em direção a s ficam resistentes à ação de ACTH apenas apōs 6 horas de estımulação. A partir deste ponto o número de células resistentes a ACTH aumenta progressivamente da mesma forma que a função entrada de cēlulas em s. Como o "lag" observado para entrada em $S$ fol de 11 horas, pode-se dizer que as cêlulas estimuladas por PF ficam resistentes à ação de АCTH 5 horas antes da entrada em $\mathrm{s}$. 


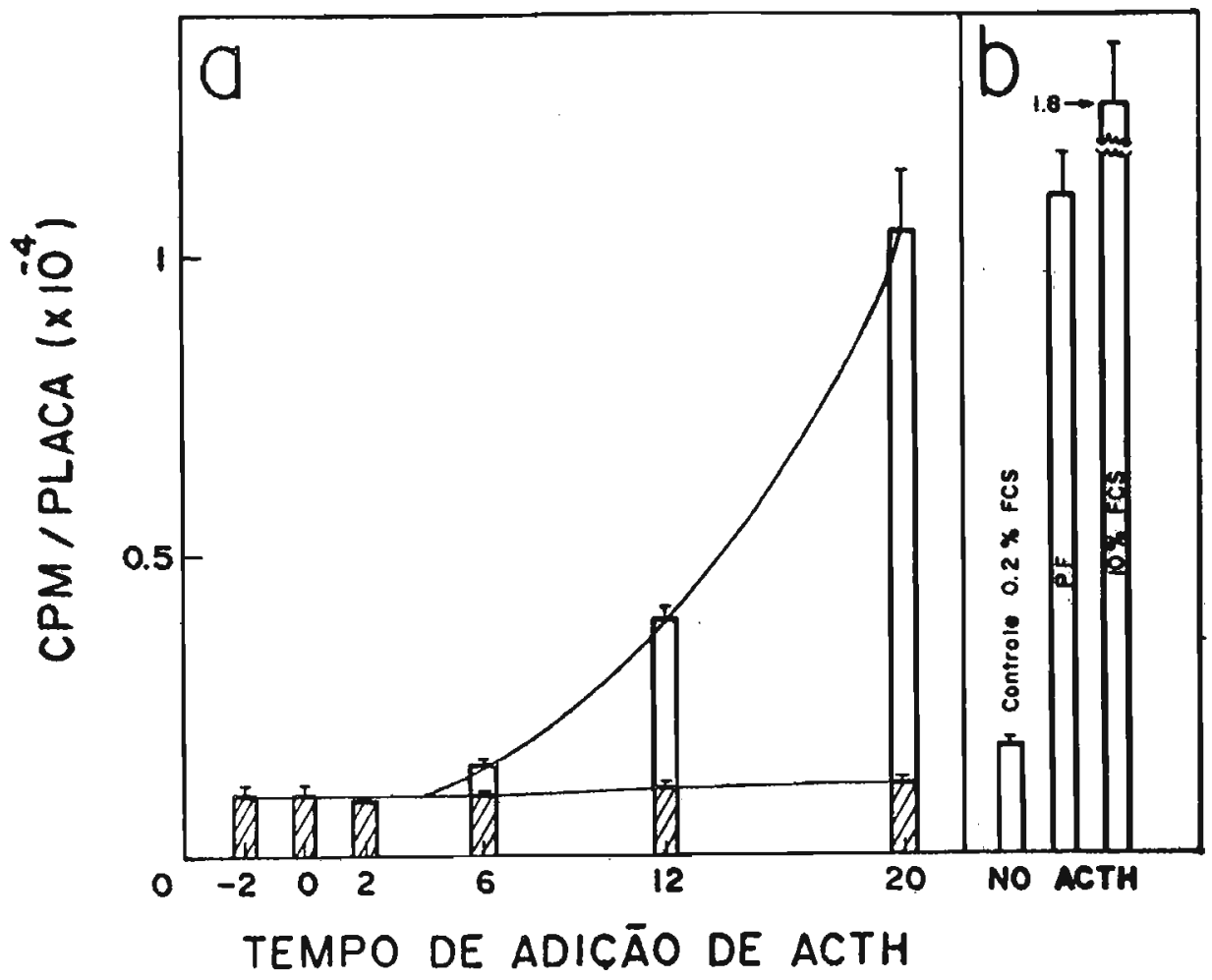

Fig. 49 - Cinētica da inibição, por ACTH, da atividade estimula tória de PF. a) Células $Y-1$ carenciadas para soro foram estimu ladas com $1 \mathrm{~g} / \mathrm{ml} \mathrm{PF}$ em $t=0$. Nos tempos indicados, $\mathrm{ACTH}(0, \overline{6}$ $\mathrm{U} / \mathrm{ml}$ ) foi adicionado a culturas estimuladas ( $\square$ ) e não estimuladas (U); b) Contrles (sem adição de ACTH). Timidina ${ }_{\mathrm{H}}$ fol incorporada entre 13 e 32 horas.

Os resultados apresentados acima nos indicaram que células $Y-1$ só seriam sensíveis a $\mathrm{ACTH}$ se estivessem num periodo anterior a $\mathrm{Gl}^{\mathrm{C}}$. Procurando analisar esta idêia mats a fundo, outro tipo de experiência foi felto: cēlulas em crescimento exponencial, em meio contendo 108 de soro, receberam ACTH. Periodicamente foram efetuados pulsos de timidina. ${ }^{3} \mathrm{H}$ e a porcentagem de núcleos marcados foi medida. Os resultados são apresentados na fig. 50. Verificou-se que o indice de marcação permanece constante pelas primeiras 5 horas e depois cai continuamen te pelas 7 horas seguintes atē agingir níveis negligenciáveis. 


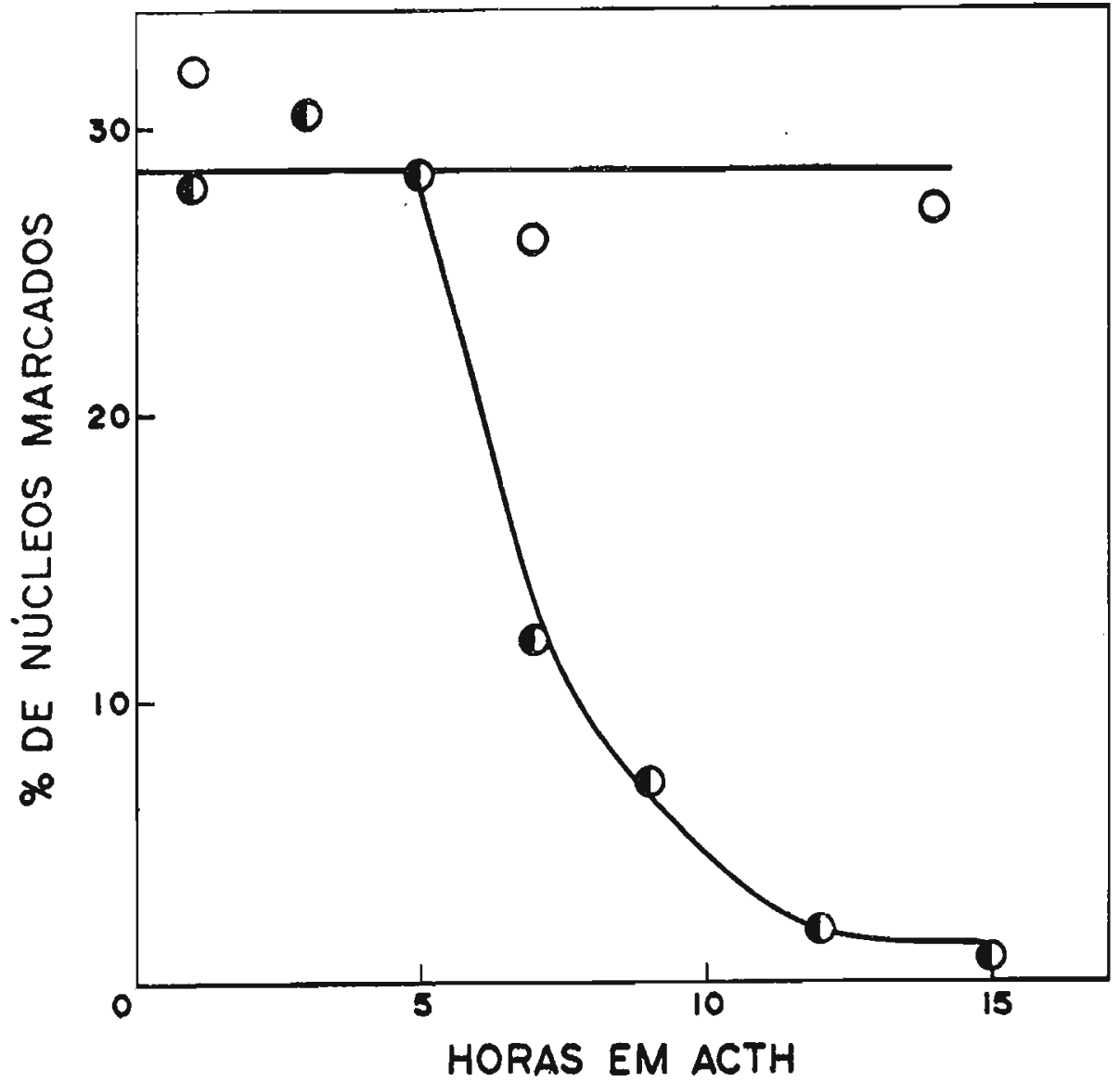

Fig. 50 - Efeito de ACTH no Indice de marcação de cêlulas Y-1 crescendo exponencialmente. O- Controle (108 FCS), 0-0 Tratadas com ACTH $(0,6 \mathrm{U} / \mathrm{ml})$.

Durante as prlmeiras 14 horas após a adıção de ACTH a velocidade de crescimento não se altera e o Indice mitótico permane ce constante conforme mostram os dados da fig. 51. Estes resultados mostram claramente que somente células pós-mitóticas que estão 5 horas antes de $\mathrm{S}$ são sensiveis a ACTH. A situa ção de ACTH em relação à células adrenais ē, portanto, muito semelhante à de hidrocortisona em cêlulas STl. Logo, podemos adotar a mesma interpretação, isto é, células em Go são blo queadas por $\mathrm{ACTH}$ mas assim que entram em $\mathrm{Gl}^{\mathrm{C}}$ tornam-se resistentes a ACTH. 


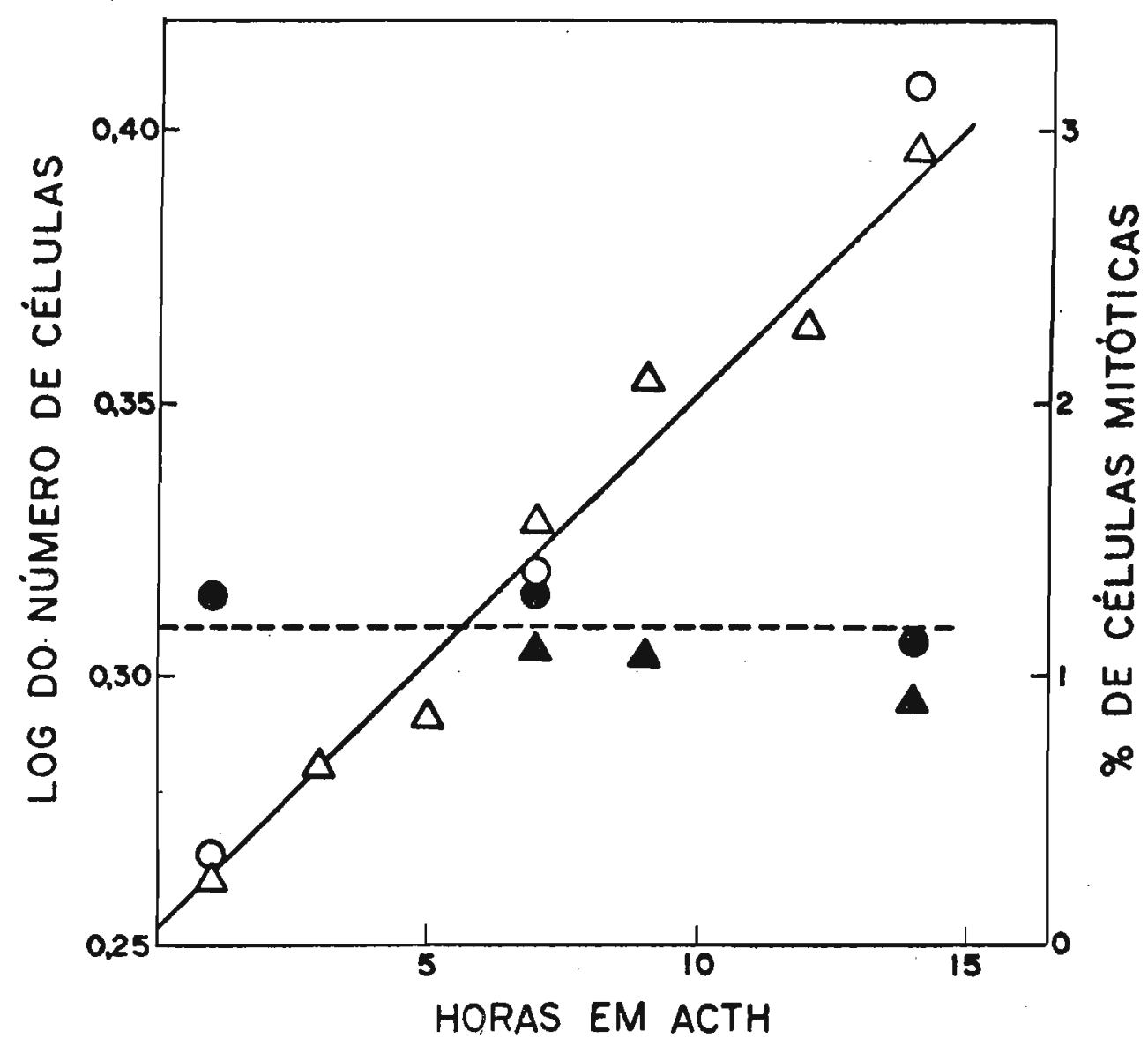

Fig. 51 - Efeito de ACTH na velocidade de crescimento e no In dice mitötico de células $\mathrm{Y}-1$ crescendo exponencialmente. Cur vas de crescimento de culturas não tratadas $(0-0)$ ou trata= das com $0,6 \mathrm{U} / \mathrm{ml}$ ACTH $(\Delta-\Delta)$. Indice mitótico de culturas não tratadas $(\longrightarrow)$ ou tratadas com $0,6 \mathrm{U} / \mathrm{ml}$ ACTH $(\Lambda-\Lambda)$.

5. ANALLISE DO COMPORTAMENTO DO VARIANTE AR-I DERIVADO DE CELULAS ADRENAIS Y-1 e RESISTENTE A ACTH

Desde que foi descoberta (MASUI \& GARREN, 1971) que ACTH Intbe o crescimento de células adrenais, foi proposto que esta ação do hormônio era mediada por CAMP. Entretanto, após esta sugestão iniclal, nenhum progresso foi feito.

Levando em conta que: a) o efeito de ACTH sobre cêlu las $Y-I$ é muito semelhante ao efeito de hidrocortisona em 
células STl; b) como vimos, o efeito primário de hidrocortisona parece ser a nível do citoesqueleto; c) cAMP pode exercer "atividade" ao nível de componentes do citoesqueleto; d) o citoesqueleto parece ser um mediador (e talvez o mediador cen tral) importante na transição $\mathrm{Go} \rightarrow \mathrm{Gl}^{\mathrm{C}}$; e) ACTH leva ao arredondamento de células $\mathrm{Y}-1$, alteração esta que depende da ativi dade do citoesqueleto - ocorreu-nos tentar um método de sele Ção de mutantes de células Y-l resistentes a ACTH. Estes mutantes seriam muito úteis ao estudo dos mecanismos de ação de ACTH em células adrenais.

\subsection{Isolamento da Linhagem AR-1}

o mētodo de seleção consistiu no isolamento de célu las $Y-1$ que não se arredondavam com $\mathrm{ACTH}$ e posterior teste de resposta a ACTH e CAMP.

A seleção envolveu tratamentos sucessivos de cultu ras de células $\mathrm{Y}-1$ com o hormônio, remoção das células arredon dadas e recuperação das cêlulas achatadas. Uma vez obtida uma população enriquectda em células achatadas na presença do hormônio, procedeur'se à clonagem (item 8 de Mētodos) e isolamento de colônias com morfologia alterada em relação à linhagem parental Y-1. Este procedimento levou ao isolamento do variante designado $\mathrm{AR}-1$ ○ qual apresenta as seguintes caracteristi cas: a) morfologia do tipo fibroblasto; b) alta eficiência de plaqueamento (maior que 50\%); c) baixa densidade de saturação; d) $\mathrm{T}_{\mathrm{D}}$ de 24 horas em meio contendo $10 \%$ de soro; e) ausência de arredondamento na presença de ACTH. 
Os variantes de células Y-1 resistentes a ACTH isoladas anteriormente (SHIMMER, 1969, 1972) respondem a CAMP. Por outro lado o variante isolado por nós não arredonda na presença de CAMP (em concentrações de até $1 \mathrm{mM}$ ).

5.2. Efeito de Soro, Hormônios e Fatores de Crescimento

Os resultados, apresentados na tabela IX mostram que a carência de soro leva à diminuição acentuada da sintese de DNA (as células entram em repouso) e que estas células podem ser reestimuladas por soro e PF. ACTH não altera a estimula ção dada por soro e PF. O resultado mais surpreendente, porém, foi a estimulação da sintese de DNA dada por ACTH . (de 250\%) uma vez que a linhagem parental Y-l é totalmente inibida por este hormônio e que outras linhagens testadas (3T3 e ST1) não mostraram qualquer resposta a ACTH. A curva de resposta de dọse a ACTH na presença de $0,2 \%$ de soro è apresentada na fig. 52. Concentrações mais altas $(1,2 \mathrm{U} / \mathrm{ml})$ causaram alte ração morfológica apōs 6 horas e lise de $100 \%$ das cêlulas apōs 20 horas de incubação. A mesma curva, feita em 8 \& de soro,não revelou efeito algum de ACTH sobre a sintese de DNA.

A resposta a oụtros hormônios foi também testada. Insulina não teve efeito algum enquanto hidrocortisona apresentou estimulação de cerca de 458 da sintese de DNA (resultados não mostrados). Alêm disso a estimulação dada por PF não è poten clada por hidrocortisona (ã semelhança da linhagem parental Y-1 e ao contrārio do observado para fibroblastos 3T3). 
Tabela IX - Atividade estimulatōria de soro, PF e ACTH sobre a sintese de DNA de células AR-1

$\mathrm{cpm} / \mathrm{placa}$

Controle $(0,2 \% \mathrm{FCS})$ 1350

Soro (10\% FCS)

14100

$\mathrm{PF} \quad(1,0 \mu \mathrm{g} / \mathrm{ml})$

14400

ACTH $(300 \mathrm{mU} / \mathrm{ml})$ 3300

Soro (10\% FCS) + ACTH $(300 \mathrm{mU} / \mathrm{ml})$ 12500

$\mathrm{PF}(1,0 \mu \mathrm{g} / \mathrm{ml})+\mathrm{ACTH}(300 \mathrm{mU} / \mathrm{ml})$ 12300

Atividades medidas de acordo com protocolo descrito em Métodos

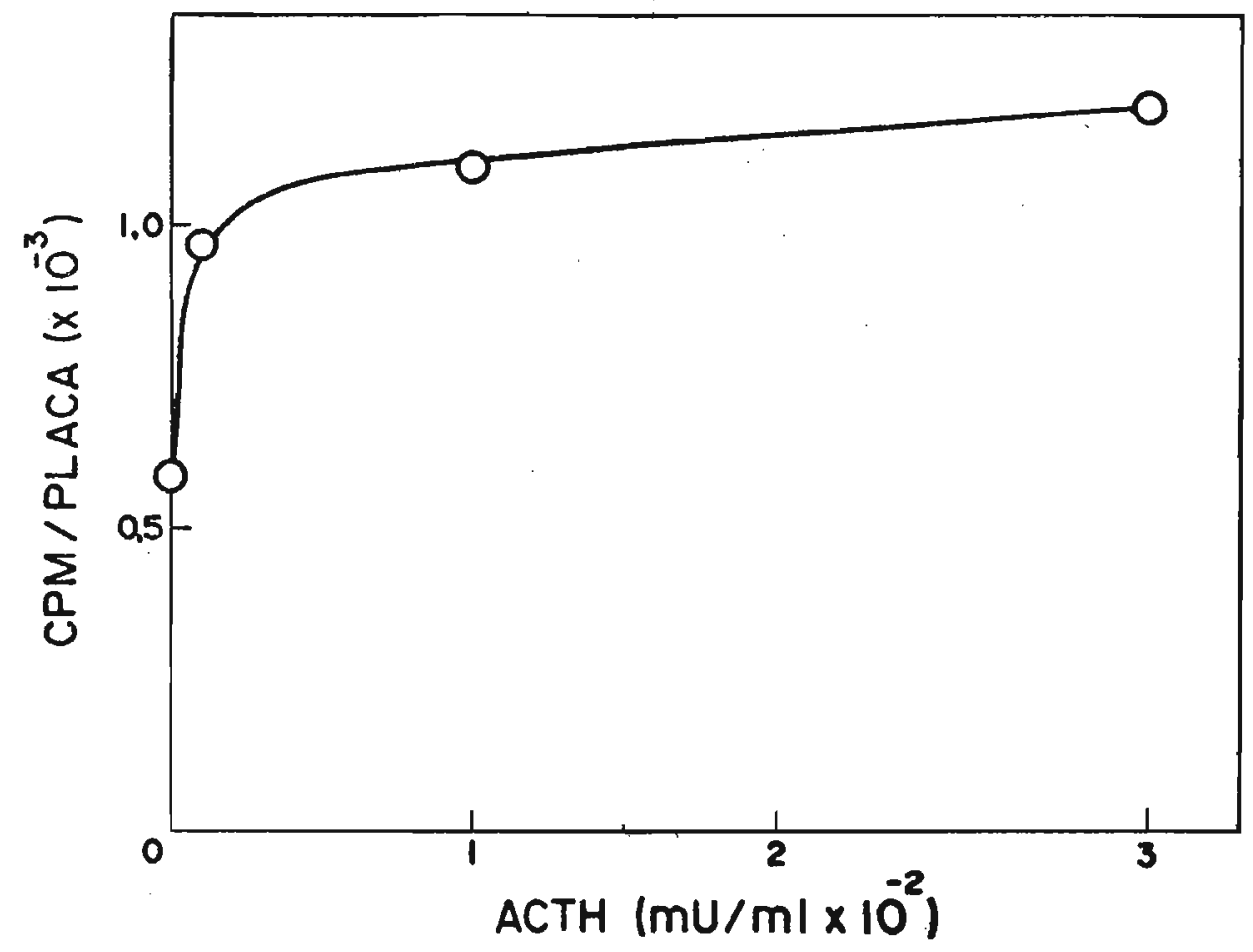

Fig. 52 - Curva de dose de ACTH para células AR-1 na presença de 0,28 FCS. Atividade estimulatória da sintese de DNA medida como descrito em Métodos. 


\subsection{Efeito de çAMP}

O efeito de CAMP sobre a síntese de DNA pode ser visto na tabela $x$. Verificou-se que a adição deste nucleotideo a células em repouso não causa efeito algum (o pequeno efeito 1nibitōrio observado não parece significativo). Além disso a estimulação dada por PF não é afetada por cAMP.

Tabela X - Efeito de CAMP sobre a atividade estimulatória de $\mathrm{PF}$ e soro na síntese de DNA de células AR-1

cpm/placa

Controle $(0,28$ FCS $)$

CAMP $\left(10^{-3} \mathrm{M}\right)$ 680

CAMP $\left(10^{-4} \mathrm{M}\right)$ 570

CAMP $\left(10^{-5} \mathrm{M}\right)$ 670

PF $(1 \mu \mathrm{g} / \mathrm{ml})$ 6470

$\mathrm{PF}(1 \mu \mathrm{g} / \mathrm{ml})+\mathrm{CAMP}\left(10^{-3} \mathrm{M}\right)$ 6420

Soro ( 108 FCS) 5400

Soro $(108 \mathrm{FCS})+\operatorname{CAMP}\left(10^{-3} \mathrm{M}\right)$ 5050

Atividades medidas de acordo com protocolo descrito em Métodos.

Medidas do efeito de ACTH no conteūdo de cAMP intrace lular foram feltas pelo método descrito no item 14 de Mêtodos. Resultados preliminares mostraram que o cAMP intracelular de células crescendo exponencialmente na presença de $5 \%$ de soro è de 15,5 pmoles/mg de proteína e que 3 vezes este valor fol obtido quando as células foram incubadas durante 1 hora com ACTH. 
E possivel notar, portanto, que o variante postulado no início desta seção pode ser obtido. Este resultado por si só sugere que ACTH e/ou CAMP bloqueiam a transição Go $\rightarrow \mathrm{Gl}^{\mathrm{C}}$, agindo ao nível do citoesqueleto. Além disso esperamos que a exploração destes mutantes traga, no futuro, novas informa ções importantes. 
IV. DISCUSSÃO

\section{CÉLULAS NORMAIS E CELULAS TRANSFORMADAS}

Fibroblastos $3 \mathrm{~T} 3$ em cultura apresentam pelo menos dois tipos de manifestações do controle de crescimento: a) ces sação reversível de crescimento na presença de altas concen trações de soro, após formação de uma monocamada confluente de células (TODARO et al., 1965); b) alto requerimento para soro, ou seja, o crescimento é dependente de altas concentrações de soro (HOLLEY \& KIERNAN, 1968). Por outro lado, células $3 \mathrm{~T} 3$ transformadas (por agentes químicos e físicos ou por infecção com vỉrus SV40) não param de crescer ao atin gir confluência (SAMBROOK, 1972) ou ao serem submetidas à carência de soro (ARMELIN, 1973).

Estas diferenças foram, por muito tempo, correlacionadas com a habilidade de células sv3T3 de induzir a formaÇão de tumores em animais apropriados (AARONSON \& TODARO, 1968) e ausência desta propriedade em cēlulas 3T3.

Alēm da perda de controle de crescimento outros parậ metros, medidos em cultura, como produção de ativador de plasminogênto e habilidade de crescer en melo semi-sōlido (POLLACK et al., 1975) foram correlacionados com tumorogenici dade.

A tentativa de correlacionar transformação, medida em cultura, com estado neoplásico tem encontrado algumas difí culdades. Assim, BOONE (1975) relatou que a Iinhagem 3T3 
que, em cultura, apresenta manifestações de controle de crescimento (dependência de soro e densidade), sob determina das condições, podia desenvolver hemangioendoteliomas em animais. Por outro lado, linhagens de cêlulas humanas tipicamen te transformadas, por vārios critērios, deixaram de produ zir tumores quando injetadas em camundongos "nude" (STILES et al., 1975). Estes resultados, entretanto não devem ser tomados como indicação de que não é possível correlacionar transformação com estado neoplásico uma vez que: a) a indução de hemangioendotelioma por células $3 T 3$ não tem podido ser reproduzida em outros laboratōrios e, alēm disso, poderia ser explicada por interferências do sistema inflamatōrio uma vez que as condições experimentais envolviam a implantação nos animais de esferas de vidro em cuja superficie cresciam as cêlulas; b) outros autores (KOPROWISKI, 1977) puderam mostrar que as linhagens transformadas que STILES et al. (1975) relataram como não tumorogênicas eram de fato tumorogềnicas se - inōculo empregado fosse maior. E importante notar também que a primeira série de linhagens de células 3T3 desenvolvida por TODARO \& GREEN (1963) foi a partir de embriões da "Iinhagem" alogênica de camundongos Swiss. Posteriormente AARONSON \& TODARO (1968) desenvolveram outra sērie de linhagens 3T3, pelo mesmo processo, mas agora de embriões de camundongos da linhagem isogênica Balb C. Assim, algumas das contradições, encontradas nos resultados de vārios laboratō rios, podem ser devidas ao emprego de células de diferentes origens ou atē de células da mesma origem porēm mantidas em condições diferentes pelos diversos laboratōrios. 
o estabelecimento definitivo da correlação transformação em cultura - estado neopläsico deve aguardar, porēm, um estudo mais sistemático. A disponibilidade de camundongos "nude" permitindo ensaios de tumorogenicidade, vem facili tar estes estudos.

Os limites de "normalidade" ou transformação em cultura são às vezes bastante difusos mas de uma maneira geral o estudo do comportamento de diversas linhagens frente à carência de soro permite agrupá-las em três categorias (ARMELIN \& ARMELIN, 1977): a) não reguladas: onde a sintese de DNA sofre pequena ou nenhuma alteração quando submetidas à baixa concentração ou ausência total de soro. Células deste tipo são representadas pela linhagem SV3T3; b) totalmente reguladas:on de a carência de soro conduz a níveis negligenciáveis da sintese de DNA, exemplificado pela linhagem 3T3; c) parcialmente reguladas: nas quais a sintese de DNA diminui (de 3 a 10 vezes) quando carencladas para soro. Um exemplo deste tipo de células è a linhagem Y-1 de células adrenals. As cêlu las tumorogênicas examinadas até agora mostram-se ou não regu ladas ou parclalmente reguladas. A IInhagem STI aqui descrita, por sua vez, comporta-se como parclalmente ou totalmen te regulada conforme esteja na ausêncta ou na presença de hidrocortisona, respectivamente.

\section{NATUREZA DOS FATORES DE CRESCIMENTO}

Operacionalmente podemos definir fator de crescimen to como substânclas que Ilmitam o cresclmento quando presen tes em concentrações sub-ótımas. 
A endocrinologia clássica estabeleceu que o controle de crescimento "in vivo" é exercido por hormônios, substân cias que apresentam as seguintes caracteristicas: a) produzidos e secretados em pequenas quantidades por glândulas endócrinas; b) agem ao nível celular em concentrações muito bai xas (da ordem de $\mathrm{ng} / \mathrm{ml}$ ) produzindo efeitos definidos em cêlu las-alvo especificas; c) capazes de desencadear reações bioquí micas que persistem mesmo quando não é mais possivel detec tar sua presença.

E razoável supor que o crescimento de células em cul tura está na dependência de substâncias reguladoras presen tes no soro, uma vez que outras substâncias essenciais (nutri entes) são adequadamente supridas pela parte quimicamente definida do meio de cultura.

A abordagem experimental utilizada para identificação de substâncias reguladoras do crescimento de células em cultura levou ao isolamento do fator de pituitäria (PF).

Os resultados aqui apresentados e outros já publicados (ARMELIN, 1973; ARMELIN \& ARMELIN, 1975; ARMELIN et al., 1976, 1977) apontam para a natureza hormonal deste fator de crescimento uma vez que: a) age em concentrações fisiológicas, ou seja,comparáveis aos nîveis hormonais detectados "in vivo"; b) age ao nível celular; c) é capaz de desenca dear reações bioquímicas as quais resultam em multiplica ção celular; d) o efeito é dependente da concentração; e) sua ação pode ser potenciada por hormônios clássicos (insulina e hidrocortisona). 


\section{FATORES DE CRESCIMENTO E CICLO CELULAR}

No modelo de ciclo celular proposto (fig. 4) o controle de crescimento seria exercido através de reguladores po sitivos ou negativos que agiriam estimulando ou inibindo a passagem de células de um estado de repouso (Go) para a fase proliferativa. Esta idéia foi corroborada pelos resultados aqui apresentados nos quais: a) o tamanho da fase prëreplicativa ("lag" ou Gl) é o mesmo para culturas estimula das com soro ou PF ou ainda combinações de PF com outros fatores de crescimento (EGF) ou com hormônios clässicos (hıdro cortisona, insulina), indlcando que todos estes fatores estão agindo no mesmo ponto; b) variações na intensidade da resposta são devidas à diferentes proporções de células que estão sendo estimuladas a deixar Go.

o modelo supõe ainda que após delxarem Go em dire ção a $S$, numa certa altura $\left(G 1^{c}\right)$, as cẹlulas tornam-se irreversivelmente comprometidas com o processo replicativo. Evi dências à favor destas idẻias foram obtidas durante o estụ do da ação de ACTH em células adrenais Y-l e do efeito provo cado por diminuição da concentração de soro e/ou adição de hidrocortisona em fibroblastos STl e 3T.3.

4. EFEITO DE HIDROCORTISONA NO MUTANTE STI

Usando diversos métodos de seleção POLLACK e colaboradores (VOGEL \& POLLACK, 1973; VOGEL et al., 1973; 1974) obtiveram duas classes de revertentẹ ou variantes de células SV3T3: a) revertentes de densidade que crescem tanto em 
1\% como em 10\% de soro mas cuja densidade de saturação é seme lhante à de células $3 \mathrm{~T} 3$; b) revertentes de soro que crescem apenas em $10 \%$ de soro e não em 18 e cuja densidade de satura ção é também a de 3T3. Os autores concluiram que a alteração da resposta a soro leva necessariamente à alteração da densidade de saturação uma vez que não foi possível isolar variantes com resposta normal à soro porém que atıngisse alta densi dade de saturação. Os resultados aqui apresentados mostram que o mutante STl por nós isolado é exatamente este tipo de mutante uma vez que atinge alta densidade de saturação (como SV3T3) porēm è dependente de soro (como 3T3).

O estudo deste mutante revelou que suas potencialida des vão muito mais longe. A resposta estimulatōria de crescimento que apresenta frente à preparações impuras de albumina de soro bovino aliada à total ausência de resposta à inū meros outros fatores ativos em cēlulas $3 \mathrm{~T} 3$ pode vir a permi tir o isolamento de um novo fator de crescimento. A tarefa de purificação desta atividade, usando a resposta estimulatória em células ST्l como ensaio, está sendo levada adiante.

Além disso células STl parecem constituir-se em exce lente modelo experimental para estudos de mecanismos de regulação do crescimento celular por esterōides. Tem sido mostra do que glicocorticóides estimulam o crescimento de células 3T3 "normais" (ARMELIN, 1973; THRASH \& CUNNINGHAM, 1973 e resultados aqui apresentados). Este fato è um tanto intrigante uma vez que fibroblastos normalmente são inibidos por glico corticōides (DOUGHERTY et a1., 1973; FODGE \& RUBIN, 1975).Por tanto não é de se estranhar que células STl sejam inibidas por 
glicocorticōides embora a atividade inibitōria não pudesse ser perfeitamente correlaçionada com atividade glicocorticōide. Se ria interessante verificar se o padrão de inibição aqui descrito para células STl constituiu-se numa resposta comum" para fibroblastos. Esta expectativa é bastante razoāvel em vista de resultados publicados para células de embrião de galinha (FODGE \& RUBIN, 1975) e células L (WIGLER et al., 1975).

o efeito de hormônios esterōides em células STl revelou-se dramático: a adição de um único hormônio provoca mudança reversível no fenōtipo celular de um padrão de crescimento transformado para um padrão "normal". Embora seja ainda questionávèl de que maneira os critérios de normalidade, postū lados em cultura, se correlacionam com a fisiologia "in vivo" (POLLACK et al., 1975; STILES et al., 1976) parece extremamente significativo o fato da reversão fenotípica causada por hidrocortisona ocorrer tanto "in vitro" como "in, vivo".

A frequente associação de altos níveis de cAMP com inibição de crescimento celular (JOHNSON \& PASTAN, 1971; OTTEN et al., 1971; 1972; SEIFERT \& PAUL, 1972; SHEPPARD \& PRASAD, 1973) e de baixos níveis de cAMP com estimulação de crescimento (SHEPPARD, 1972) tem levado à proposição deste nucleotídeo como um importante componente do sistema de controle da proliferação (SHEPPARD \& BANNAI, 1974).

Medidas dos níveis de cAMP de células STl em condições de inibição por hidrocortisona mostraram que o hormônio não causa alteração nos níveis de cAMP. Isto sugere que este nucleotídeo não è um mediador da ação de hidrocortisona e 
que este hormônio deve agir diretamente sobre o sistema

controle central.

Um outro aspecto extremamente interessante do mutante STl tem a ver com a profunda alteração morfológica de arredondamento provocada por retirada do soro ou por cAMP exóge no. Como vimos, o arredondamento provocado por cAMP é bloqueado por hidrocortisona mas este bloqueio é, por sua vez; impedido por cicloheximida, indicando que a ação de hidrocor tisona é dependente de sintese de proteína. O processo de ar redondamento é inibido por colchicina, o que aponta para o en volvimento de microtúbulos no fenômeno. Portanto a ruptura do citoesqueleto torna as células incapazes de responder com esta alteração morfológica.

E importante lembrar que arredondamento, apōs retira da de soro do meio de cultura; não è observado na linhagem parental nem em outras linhagens e nem em culturas primárias de fibroblastos. Logo, as células STl devem possuir uma alteração ou defeito que leva ao aparecimento desta resposta morfológica. Esta mesma alteração talvez seja responsāvel também pela pouca adesão da célula à superfície ou às células vizinhas e ainda seja tambēm a causa primária do fenōtipotrans formado. A alteração ou defeito ao qual estamos aludindo deve se localisar no complexo sistema superficie celular - membrana - citoesqueleto. A hipótese que sugerimos è que hidrocortisona exerce sua ação, em células STI, promovendo um repa ro do defeito do sistema membrana-citoesqueleto, reconstituin do, assim, um comportamento normal às cëlulas (pelo menos 
parcialmente). Esta hipōtese pode ser testada atravēs de uma anālise dos componentes do sistema membrana - citoesqueleto. Parece-nos que se deve começar estudando os seguintes compo nentes: mucopolissacarídeos, glicoproteínas e componentes fibrilares (microtūbulos e microfilamentos).

Mucopolissacarídeos têm sido implicados em processos de adesão e reconhecimento celular. Alêm disso observou-se que a composição de mucopolissacarideos sulfatados de células normais difere fundamentalmente daquela de células transformadas ou tumorais, sugerindo o envolvimento destas substâncias em processos regulatôrios do crescimento (DIETRICH et al., 1976). A anālıse da composição de mucopo lissacarídeos sulfatados de células STl na ausência e na presença de hidrocortisona, è, portanto, de grande interesse.

Alterações de certas proteínas da superficle celular têm sido correlacionadas com o fenômeno de t transforma ção (ver HYNES, 1976). Uma destas protelnas fol designada pe la sigla LETS ("large external transformation sensitive protein") por apresentar alto peso molecular (da ordem de 250.000), ser passível de marcação por lactoperoxidase e estar ausente ou muito reduzida em superfícies de células trans formadas. Além disso foi possível mostrar que esta proteína è sintetizada pela célula (HYNES \& HUMPHRYES, 1974; ROBBINS et al., 1974; STONE et al., 1974;. CRICHLEY, 1974; YAMADA \& WESTON, 1974) e estā presente na superfície de células cres cendo exponencialmente em muito menor quantídade do que em células cujo crescimento é bloqueado por efeitos de densidade ou de retirada do soro (HYNES, 1974; GAHMBERG et al.,1974; 
ROBBINS et al., 1974; CRICHLEY, 1974; PEARLSTEIN \& WATERFIELD, 1974; HYNES \& BYE, 1974). Evidências diretas da indução da sintese de proteínas (do tipo LETS) em células STl, por hidro cortisona, poderiam ser obtidas por iodação da superfície celular usando lactoperoxidase e eletroforese. Experiências nes te sentido serão levadas a efeito no futuro.

Evidências em favor do envolvimento de estruturas $\mathrm{f} \underline{\underline{i}}$ brilares (microtūbulos e microfilamentos) num grande nümero de processos celulares (como crescimento, mobilidade e reco nhecimento celular) estão se acumulando (EDELMAN, 1976). "De feitos" na arquitetura do citoesqueleto de células transforma das têm sido descritos (BRINKLEY et al., 1975; EDELMAN \& YAHARA, 1976). E possível que hidrocortisona induza um "repa ro" no citoesqueleto de células STl. Um teste inicial desta possibilidade pode ser feito usando colchicina como ferramenta.

Através de estudos cinéticos do efeito de colchicina na curva de acumulação de mitoses em culturas crescendo exponencialmente PUCK (1964), em trabalho clässico, concluiu que - ponto de ação de colchicina era ao nível da mitose. Desde então colchicina (e tambëm vinblastina, vincristina e outros alcalóides derivados de Vinca) têm sido largamente empregados para sincronização de cēlulas em M. Entretanto, se um controle existe ao nível de microtúbulos causando bloqueio da transição Go $\rightarrow \mathrm{Gl}$, um segundo bloqueio seria esperado além daquele descrito por Puck. Neste caso, células que se encon tram além do ponto de bloqueio (ou seja $G l^{C}$, s ou G2) não seriam afetadas pelo inibidor e, portanto, continuariam 
acumular em M. Por outro lado, cêlulas que estão aquém do ponto de bloqueio (em Go) acumulariam em Go, não contribuindo, portanto para a fração de células em M. A função acumulação de mitoses deveria ser linear por um certo tempo (igual a $\mathrm{Gl}^{\mathrm{C}}+\mathrm{S}+\mathrm{G} 2$ ) para, depois, atingir um "plateau" que corresponderia à fração de células bloqueadas ao nivel de Go $\rightarrow$ Gl. Assim, se colchicina provocar bloqueio de células em Go, a curva de acumulação de mitoses, para células STl crescendo exponencialmente na presença e na ausência de hidrocortisona, deveria fornecer resultados diferentes. Esta possibilidade está sendo investigada em nosso laboratōrio.

\section{EFEITO DE ACTH EM CELULAS ADRENAIS}

O efeito do hormônio hipofisārio ACTH sobre células adrenais tem sido estudado tanto "in vivo" como "in vitro".

Vărios autores têm observado estimulação do crescimento de glândulas adrenais em animais injetados com ACTH (FARESE \& REDDY, 1963; IMRIE et al., 1965; MASUI \& GARREN, 1970). Estes dados e o fato de hipofisectomia levar à atrofia da glândula adrenal e desta poder ser mantida por administração de ACTH tem levado certos autores (GARREN et al., 1971) a propor um papel trōpico deste hormônio para células adrenais.

A linhagem tumoral funcional $\mathrm{Y}-1$ responde a ACTH com um aumento de esteroidogênese e uma alteração na morfologia(SATO et al., 1970). O crescimento destas células, porém, é inibido por ACTH (MASUI \& GARREN, 1971 e resultados aqui apresenta dos). Alēm disso MASUI \& LA PORTE (1973) mostraram que ACTH 
inibe o crescimento de células Y-l também "in vivo" (quando trans plantadas em camundongos isogênicos).

Assim, efeitos aparentemente contraditórios de ACTH sobre o crescimento de células de cortex adrenal normal e de tumores adrenais estavam sendo obtidos, atribuindo-se o efelto inibitório em células Y-l a uma resposta anormal de uma cêlula tumoral.

Contudo resultados obtidos por outros investigadores (RAMACHANDRAN \& SUYAMA, 1975) mostraram que a sintese de DNA em culturas primárias de células adrenais normais era tambëm inibida por ACTH. Estes mesmos autores sugeriram que o papel de ACTH estaria ligado a processos de diferenciação da glândula adrenal enquanto a prolịferação de células adrenais estaria sob o controle de outros fatores.

Neste contexto torna-se extremamente interessante que a glândula pituităria possua fatores estimuladores da síntese de DNA para células Y-l (GOSPODAROWICZ \& HANDLEY, 1975; ARMELIN, 1975 e resultados aqui apresentạos) e tambēm para células adrenocorticals normais de origem bovina (GOSPODAROWICZ et al.,1977) alguns destes fatores apresentando, inclusive, uma certa especificidade para estas células (ARMELIN et al., 1977). Estes resul tados levam-nos a indagar se o efeito estimulatório de ACTH observado "in vivo" não poderia ser atribuido a substânclas contaminantes da preparação de ACTH (à partir de glândula pituitāria) uma vez que doses muito altas foram usadas nestes estudos.

O papel de ACTH como hormônio diferenclador tem sido bastante explorado. Já em 1957 HAYNES \& BERTHET sugeriram o 
envolvimento de CAMP na esteroidogênese adrenal. MASUI

GARREN (1971) mostraram que cAMP exógeno era capaz de mimeti zar o efeito de ACTH em células Y-l tanto em relação à síntẹ se de DNA como à alteração morfológica. SHIMMER (1972) verifí cou que ACTH provocava estimulação da adenilato ciclase em células Y-1 mas não nos variantes Y-6 e OS3 (SHIMMER, 1969) que são insensiveis à adição de ACTH. Entretanto estes varian tes mostravam-se sensive1s à adição de CAMP (SHIMMER,1969,1972) sugerindo que o defeito nestas cëlulas era ao nivel de um receptor ou de uma adenilato ciclase sensivel a ACTH. Alëm disso revertentes fenotipicos de células insensivels a ACTH recuperam a seṇsibilidade tanto com respeito a adenilato ciclase como a esteroldogênese (ȘHIMMER, 1976). Estas observações têm levado à postulação de cAMP como um componente obrigatório da esterolaogênese estimulada por ACTH (SHIMMER \& ZIMMERMAN, 1976).

o trabalho relatado nesta tese adicionou de novo a este quadro, a demonstração de que ACTH age exclusivamente em células no estado Go. Talvez este dado permita que se comece a entender de que maneira estimuladores e inibidores da divisão celular promovem o controle da proliferação e da citodiferenclação nos tecldos que estão sujeltos à renovação celular, no animal adulto. Mais que isso, os resultados aqui apresenta dos, Indicam que o sistema $Y-1$ submetido à ação de PF e ACTH representa um modelo realista e útil para o estudo de controle do cresclmento e diferenciação de cêlulas da cortex suprarenal.

Mu1to embora АCTH possa exercer sua ação inibitó ria sobre a proliferação celular via CAMP, nada se sabe 
ainda sobre como CAMP poderia exercer esta mediação. O fato de ACTH causar o arredondamento de células Y-1 sugeriu-nos que este hormônio poderia agir ao nível do citoesqueleto para causar inibição pois o citoesqueleto talvez seja o principal mediador na regulação do crescimento e da divisão celu lar. Como corolārio desta hipótese tínhamos que a seleção de células Y-l que não se arredondam na presença de ACTH, pro vavelmente forneceria células resistentes a ACTH e, talvez,tam bém resistentes a CAMP, se este fosse, de fato, o mediador des ta ação do hormônio. De fato a linhagem AR-1, selecionada por este processo, revelou ser uma cêlula cuja síntese de DNA é estimulada.por PF ou soro, sem que esta estimulação seja blo queada por ACTH ou CAMP. Estes resultados fornecem evidên cias, que embora circunstanciais são sugestivas, indicando que o mediador da ação inibitōria de ACTH (via CAMP ou não) è - citoesqueleto.

Quando esta tese estava sendo escrita interessantes observações foram feitas com as células AR-1 (H.A. Armelin,re sultados não publicados). Foi observado que apesar de cAMP não inibir a estimulação, por soro, da entrada das células AR-1 em fase $S$, este nucleotídeo inibe a entrada das células em mitose. Estes dados preliminares indicam que em células $A R-1$, CAMP não bloqueia a transição $\mathrm{Go} \rightarrow \mathrm{Gl}^{\mathrm{C}}$ mas inibe a transição G2 $\rightarrow$ M. E importante lembrar que foi verificado em fibroblastos 3T3 (WIILINGHAM et al., 1972), células de fígado de rato (NOSE \& KATSUTA, 1975) e células adrenais Y-1 (GILI \& WEIDMAN, 1977) que CAMP bloqueia a entrada das células em S e, tambēm, ao nível de G2. Portanto, parece que,com 
as células AR-1, isolamos uma célula na qual os dois efeitos de cAMP estão desacoplados. E desnecessārio enfatizar a grande importância potencial que esta célula pode ter para os estudos de função e mecanismos de ação de cAMP.

Ao se considerar a exploração futura do sistema AR-1 para estudo dos mecanismos de ação de CAMP, é interessante le var em conta dados atualmente disponíveis na literatura.

Tem sido sugerido que cAMP é um mediador pleiotrópico do crescimento e de outros processos celulares (KRAM et al., 1973; OTTEN et al., 1971; PRASAD \& SHEPPARD, 1972) alēm de agir como segundo mensageiro na mediação de estímulos hormonais e outros sinais regulatórios externos (ROBISON et al., 1971).

o fato de cAMP ser envolvido num grande número de respostas celulares e de ter ampla distribuição entre os sistemas biológicos tem dificultado sua visualização como responsāvel direto pelos efeitos observados.

Por outro lado evidências em favor do envolvimento da membrana e de proteinas filamentosas da células (microtúbulos, microfilamentos e proteínas do tipo actina) num grande número de processos celulares estão se acumulando (EDELMAN, 1976) e a correlação entre funcionamento de proteínas filamentosas e níveis de CAMP parece estar emergindo (OLSEN, 1975). Assim, tubulina, a proteína de microtúbulos é formada de dímeros cada um dos quais apresenta um residuo fosforilado de serina (GOODMAN et al., 1970). Estes dimeros servem como substrato em reação de fosforilação mediada por uma quinase estimulada 
por CAMP. A fosforilação da tubulina parece ser essencial para su função, interferindo, talvez com sua conformação ou estado de agregação. E ainda cAMP inibe a ligação de colchicina à tubulina (GILLESPIE, 1971) e estabị liza microtúbulos contra dissociação por baixa temperatura (KIRKLAND \& BURTON, 1972).

Através de uma abordagem genētica INSEL et al.(1975) verificaram que existe um paralelismo perfeito entre a concentração de cAMP necessāria para inibição de crescimento (medida por acumulação de células em Gl ou Go ou por número de células) e a concentração de cAMp necessária para estimu lar a atividade de uma proteína quinase (medida por ligação especifica de CAMP ou por estimulação da fosforilação de histona).

Segundo OLSEN (1975) CAMP poderia regular a fosforilação de proteínas filamentosas atravēs da ativação de uma pro teỉna quinase. Esta fosforilação acarretaria em alterações na conformação, estado de agregação e/ou contractibilidade da proteina filamentosa, o que, em última análise controlaria os eventos bioquímicos da célula.

Dadas as sugestões e especulações citadas acima seria interessante analisar as proteinas aceptoras e as quinases dependentes de cAMP em células AR-1. A comparação dẹsta célula com a linhagem parental $\mathrm{Y}-1$ pode ajudar a responder a questão de qual a diferença entre os mecanismos de ação de CAMP ao nível de Gl e G2. 


\section{REFERENCIAS BIBLIOGRAFICAS}

AARONSON, S.A. \& TODARO, G. - "Basis for the acquisition of malignant potential by mouse cells cultivated in vitro". Science, 162, 1024-1026 (1968).

ANTONIADES, H.; STATHAKOS, S. \& SCHER, C. - "Isolation of a cationic polipeptide from human serum that stimulates proliferation of $3 \mathrm{~T} 3$ cells". Proc. Nat. Acad. Sci. USA, 72, 2635-2639 (1975).

APPLEMAN, M.M.; BIRNBAUMER, L. \& TORRES, H.N. - "Factors affecting the activity of muscle glycogen synthetase. III. The reaction with triphosphate, $\mathrm{Mg}^{++}$and cyclic $3^{\prime}, 5^{\prime}$-adenosine monophosphate". Arch. Biochem. Biophys., 116, 39-43 (1966). ARMELIN, H.A. - "Pituitary extracts and steroid hormones in the control of $3 \mathrm{~T} 3$ cell growth". Proc. Nat. Acad. Sci. USA, 70, 2702-2706 (1973).

ARMELIN, H.A. - "Hormones and Regulation of Cell Division: Mammalian cell cultures as an experimental approach".

In Biochemical Actions of Hormones; Ed. G. Litwack, vol. III, 1-21 Academic Press Inc. New York (1975).

ARMELIN, M.C.S. \& ARMELIN, H.A. - "Regulation of fibroblast growth In culture". Biochem. Blophys. Res. Canm., 62, 260-267 (1975).

ARMELIN, H.A. \& ARMELIN, M.C.S. - "Resting-proliferative transition in cultured mammalian cells". Nat. Cancer Inst. Monogr., 48 (1977 in press).

ARMELIN, M.C.S.; GAMBARINI, A.G. \& ARMELIN, H.A. - "Protein factors regulating mammalian cell growth". Arch. Biol. Med. Exper., 10, 122-129 (1976).

ARMELIN, M.C.S.; GAMBARINI, A.G. \& ARMELIN, H.A. - "On the regulation of DNA synthesis in a line of adrenocortical tumor cells: effect of serum, adrenocorticotropin and pituitary factors". J. Cell. Physiol. (in press) (1977). ASUA, L.J.; O'FARREL, M.; BENETT, D.; CLINGAN, D. \& RUDLAND, P. - "Interaction of two hormones and their effect on observed rate of initiation of DNA synthesis in $3 T 3$ cells". Nature,265, 151-153 (1977). 
AUGUSTI-TOCCO, G. \& SATO, G. - "Establishment of functional clonal lines of neurons from mouse neuroblastoma". Proc. Nat. Acad. Sci. USA, 64, 311-315 (1969).

BAKER, R.; BRUNETTE, D.; MANKOVITZ, R.; THOMPSON, L.; WHITMORE,

G.; SIMMINOVITCH, L. \& TILL, J. - "Ouabain-resistant mutants of mouse and hamster cells in culture". Cell, 1 , 9-22 (1974).

BEAUDET, A.; ROUFA, D. \& CASKEY, C. - "Mutations affecting the structure of hypoxanthine: guanine phosphoribosyl transferase in cultured Chinese hamster cells". Proc. Nat. Acad. Sci. USA, 70, 320-324 (1973).

BENDA, P.; LIGTHBODY, J.; SATO, G.; LEVTNE, L. \& SWEET, W. - "Differentlated rat glial cell strain in tissue culture". Science, 161, 370-371 (1968). BOONE, C. - "Malignant nemangloendotheliomas produced by subcutaneous inoculation of $\mathrm{Balb} / 3 \mathrm{~T} 3$ cells attached to glass beads". Sclence, 188, 68-70 (1975).

BRINKLEY, B.R.; FULLER, G.M. \& HIGHFIELD, D.P. - "Cytoplasmic microtubules in normal and transformed cells in culture: Analysis by tubulin antibody immunofluorescence". Proc. Nat. Acad. Sc1. USA, 72, 4981-4985 (1975).

BUONASSISSI, V.; SATO, G.H. \& COHEN, A.I. - "Hormone-producing cultures of adrenal and pituitary tumor origin". Proc. Nat. Acad. Sc1. USA, 48, 1184-1190 (1962).

BURGER, M. - "Proteolytic enzymes initiating cell division and scape from contact inhibition of growth". Nature, 227, 170-171 (1970).

BURGER, M.M. - "The significance of the surface structure changes for growth control under crowded conditions". Ciba Fndn. Symp. Growth Control in Cell Culture (ed. G.E.W. Wolstenholme \& J. Knight) p. 45 Churchill Livingstone, London (1971).

BURGER, M.M. - "Surface changes in transformed cells detected by lectins". Fed. Proc., 32, 91-101 (1973).

BURGER, M.M.; BOMBIK, B.N.; BRECKENRIDGE, B. \& SHEPPARD, J.R."Growth control and cyclic alterations of cyclic AMP in the cell cycle". Nature New Biol., 239, 161-163 (1972). BURGUS, R.; DUNN, T.; DESIDERIO, D.; VALE, W. \& GUILLEMIN, R."Structure moleculaire du facteur hypothalamique". C.R. Acad. Sci. Ser. D, 269, 1870-1873 (1969). 
BURNS, F.J. \& TANNOCK, I.F. - "On the existence of a Go phase in the cell cycle". Cell Tissue Kinet., 3, 321-334 (1970). BURSTIN, S.J.; MEISS, H.K. \& BASILICO, C. - "A temperature-sensitive cell cycle mutant of the BHK cell line". J. Cell. Physiol., 84,397-408(1974). BUSH, I.E. \& MALESH, V.B. - "Metabolism of 11-oxygenated steroids. 2. 2-methyl steroids". Biochem. J., 71, 718-742 (1959 CHEN, L.B. \& BUCHANAN, J. - "Mitogenic activity of blood components. I. Thrombin and prothrombin". Proc. Nat. Acad. Sci. USA, 72, 131-135 (1975).

COHEN, S. - "Isolation of a mouse submaxillary gland protein accelerating incisor eruption and eyelid opening in the new-born animal". J. Biol. Chem., 237, 1555-1562 (1962).

CRICHLEY, D.R. - "Cell surface proteins of NIL 1 hamster fibroblasts labeled by galactose oxidase, tritiated borohydride method". Cel1, $3,121-125$ (1974).

DE MARS, R. - "Resistance of cultured human fibroblasts and other cells to purine and pyrimidine analogues in relation to mutagenesis detection". Mutation Res., 24, 335-364 (1974). DIETRICH, C.P.; SAMPAIO, L.O. \& TOLEDO, O.M.S. - "Characteristic distribution of sulfated mucopolysaccharides in different tissues and in their respective mitochondria". Blochem. Biophys. Res. Comm., 71, 1-10 (1976).

DOUGHERTY, T.F.; STEVENS, W. \& SCHNEEBELI, G.L. - "Functional and morphological alterations produced in target cells by anti-inflammatory steroids". Rec. Prog. Hormone Res., 29, 287-328 (1973).

DULAK, N.C. \& TEMIN, H.M. - "A partially purified polypeptide fraction from rat liver cell conditioned medium with multiplication-stimulating activity for embryo fibroblasts". J. Cell. Physiol., 81, 153-160 (1973).

EDELMAN, G.M. - "Surface modulation in cell recognition and cell growth". Science, 192, 218-226 (1976).

EDELMAN, G.M. \& YAHARA, I. - "Temperature-sensitive changes in surface modulating assemblies of fibroblasts transformed by mutants of Rous sarcoma virus". Proc. Nat. Acad. Sci. USA, 73, 2047-2051 (1976). 
ELLIS, S. - "A scheme for the separation of pituitary proteins". J. Biol. Chem., 233, 63-68 (1958).

FARESE, R.V. \& REDDY, W.J. - "Observations on the interrelations between adrenal protein, RNA and DNA during prolonged ACTH administration". Biochem. Biophys. Acta, 76, 145-148 (1963).

FLANAGAN, S.P. - "Nude, a new hairless gene with pleiotropic effects in the mouse". Genet. Res. (Camb.), ㅇ, 295-309 (1966).

FODGE, D.W. \& RUBIN, H. - "Differential effects of glucocorticoids on DNA synthesis in normal and virus-transformed chick embryo cells". Nature, 257, 804-806 (1975).

GAHMBERG, C.G.; KIEHN, D. \& HAKAMORI, S. - "Changes in a surface-labelled galactoprotein and in glycolipid concentrations in cells transformed by a temperature-sensitive polyoma virus mutant". Nature, 248, 413-415 (1974).

GARREN, L.D.; GILL, G.N.; MASUI, H. \& WALTON, G.M. - "On the mechanism of action of ACTH". Rec. Prog. Horm. Res., 27, 433-474 (1971).

GILL, G.N. \& WEIDMAN, E.R. - "Hormonal regulation of initiation of DNA synthesis and of differentiated function in $Y-1$ adrenal cortical cells". J. Cell. Physiol., 92, 65-76 (1977).

GILLESPIE, E. - "Colchicine binding in tissue slices. Decrease by calcium and biphasic effect of adenosine-3',5'-monophosphate". J. Cell Biol., 50, 544-549 (1971).

GILMAN, A.G. - "A protein binding assay for adenosine 3',5'-cyclic monophosphate". Proc. Nat. Acad. Sci. USA, 67, 305-312 (1970).

GLYNN, R.; THRASH, C. \& CUNNINGHAM, D. - "Maximal concanavalin A-specific agglutinability without loss of density-dependent growth control". Proc. Nat. Acad. Sci. USA, 70, 2676-2677 (1973). 
GOODMAN, D.B.P.; RASMUSSEN, H.; DIBELLA, F. \& GUTHROW, C.E."Cyclic adenosine 3':5'-monophosphate-stimulated phosphorylation of isolated neurotubule subunits". Proc. Nat. Acad. Sci. USA, 67, 652-659 (1970).

GOSPODAROWICZ, D. - "Localisation of a fibroblast growth factor and its effect alone and with hydrocortisone on 3 T3 cell growth". Nature, 249, 123-127 (1974).

GOSPODAROWICZ, D. \& HANDLEY, H.H. - "Stimulation of division of $\mathrm{Y}-1$ adrenal cells by a growth factor isolated from bovine pituitary glands". Endocrinology, 97, 102-107 (1975).

GOSPODAROWICZ, D.; JONES, K.L. \& SATO, G.H. - "Purification of a growth factor for ovarian cells from bovine pituitary glands". Proc. Nat. Acad. Sci. USA, 71, 2295-2299 (1974).

GOSPODAROWICZ, D.; ILL, C.R.; HORNSBY, P.J. \& GILL, G.N. "Control of bovine adrenal cortical cell proliferation by fibroblast growth factor. Lack of effect of epidermal growth factor". Endocrinology, 100, 1080-1089 (1977). GOTTLIEB, C.; BAENZIGER, J. \& KORNFELD, S. - "Deficient uridine diphosphate-N-acetylglucosamine:Glucoprotein $\mathrm{N}$-acetylglucosaminyltransferase activity in a clone of chinese hamster ovary cells with altered surface glycoproteins. J. B1ol. Chem., 250, 3303-3309 (1975). HALL, K. \& UTHNE, K. - "Some biological properties of purified sulfation factor (SF) from human plasma". Acta Med. Scand., 190, 137-143 (1971).

HALL, K. \& VAN WYCK, J. - "Somatomedin". Curr. Top. Exp. Endocrin., 2, 155-178 (1974).

HARRIS, M. - "Mutation rates in cells at different ploidy levels". J. Cell. Physiol., 78, 177-184 (1971).

HARTWELL, L. - "Saccharomyces cerevisae Cell Cycle". Bacteriol. Rev., 38, 164-198 (1974). 
HATZFELD, J. \& BUTTIN, G. - "Temperature-sensitive cell cycle mutants: a Chinese hamster cell line with a reversible block in cytokinesis". Cell, 5, 123-129 (1975).

HAYASHI, I. \& SATO, G.H. - "Replacement of serum by hormones permits growth of cells in a defined medium". Nature, 259, 132-134 (1976).

HAYNES, R.C.Jr. \& BERTHET, L. - "Studies on the mechanism of action of the adrenocorticotropic hormone". J. Biol. Chem., 225, 115-124 (1957).

HOLLEY, R.W. \& KIERNAN, J.A. - "Contact inhibition of cell division in $3 \mathrm{~T} 3$ cells. Proc. Nat. Acad. Sci. USA, 60, 300-304 (1968).

HOLLEY, R.W. \& KIERNAN, J.A. - "Studies of serum factors required by $3 \mathrm{~T} 3$ and SV3T3 cells". In: Growth Contr. Cell Cult., Ciba Found. Symp. pp. 3-15 (1971).

HOLLEY, R.W. \& KIERNAN, J.A. - "Control of the iniciation of DNA synthesis in 3T3 cells: low-molecular-weight nutrients". Proc. Nat. Acad. Sci. USA, 71, 2942-2945 (1974).

HSU, T.C. \& POMERAT, C.M. - "Mammalian chromosomes in vitro. II. A method for spreading the chromosomes of cells in tissue culture". J. Heredity, 44, 23-29 (1953).

HYNES, R.O. - "Role of surface alterations in cell transformation: the importance of proteases and surface proteins". Cell, 1 , 147-156 (1974).

HYNES, R.O. - "Cell surface proteins and malignant transformation". Biochim. Biophys. Acta, 458, 73-107 (1976).

Hynes, R.O. \& BYE, J.M. - "Density and cell cycle dependence of cell surface proteins in hamster fibroblasts". Cell, $\underline{3}$, 113-120 (1974).

HYNES, R.O. \& HUMPHRYES, K.C. - "Characterization of the external proteins of hamster fibroblasts". J. Cell Biol., 62, 438-448 (1974). 
IMRIE, R.C.; RAMAIAH, T.R.; ANTONI, F. \& HUTCHISON, W.C. "The effect of adrenocorticotrophin on the nucleic acid metabolism of the rat adrenal gland". J. Endocrinol., 32, 303-312 (1965).

INSEL, P.A.; BOURNE, H.R.; COFFINO, P. \& TOMKINS, G.M. "Cyclic AMP-dependent protein kinase: pivotal role in regulation of enzyme induction and growth". Science, 190, 896-898 (1975).

ISAACSON, J.H. \& CATTANACH, B.M. - "Report". Mouse News Letter, $27,31-40$ (1962).

JAINCHILL, J. \& TODARO, G. - "Stimulation of cell growth in vitro by serum with and without growth factor. Relation to contact inhibition and viral transformation". Exp. Cell Res., 59, 137-146 (1970).

JOHNSON, G.S. \& PASTAN, I. - "Change in growth and morphology of fibroblasts by prostaglandins". J. Nat. Cancer Inst., 47, 1357-1364 (1971).

KIRKLAND, W.I. \& BURTON, P.R. - "Cyclic adenosine monophosphate-mediated stabilization of mouse neuroblastoma cell neurite microtubules exposed to low temperature". Nature New Biol., 240, 205-207 (1972).

KOPROWISKI, H. \& CROCE, C.M. - "Tumorigenicity of SV40 transformed human cells and human-mouse hybrids in nude mice". Proc. Nat. Acad. Sci. USA, 74, 1142-1146 (1977).

KRAM, R.P.; MAMONT, P. \& TOMKINS, G.M. - "Pleiotypic control by adenosine $3^{\prime}, 5^{\prime}$-cyclic monophosphate: A model for growth control in animal cells". Proc. Nat. Acad. Sci. USA, 70, 1432-1436 (1973).

LAJTHA, L.G. - "On the concept of cell cycle". J. Cell Comp. Physiol., 62, suppl. 143-145 (1963).

LEVI-MONTALCINI, R. \& ANGELETTI, P.U. - "Nerve growth factor". Physiol. Rev., 48, 534-550 (1968). LIPTON, A.; KINGER, I.; PAUL, D. \& HOLLEY, R.W. - "Migration of mouse $3 \mathrm{~T} 3$ fibroblasts in response to a serum factor". Proc. Nat. Acad. Sci. USA, 68, 2799-2801 (1971). 
LISKAY, R.M. - "A mammalian somatic "cell cycle" mutant defective in $G_{1}$ ". J. Cell. Physiol., 84, 49-56 (1974).

LOWRY, O.; ROSENBROUGH, J.; FARR, A. \& RANDELL, R. "Protein measurement with the Folin phenol reagent". J. Biol. Chem., 193, 265-275 (1951).

MASUI, H. \& GARREN, L.D. - "On the mechanism of action of adrenocorticotropic hormone. Stimulation of DNA polymerase and thymidine kinase activities in adrenal glands". J. Biol. Chem., 245, 2627-2636 (1970). MASUI, H. \& GARREN, L.D. - "Inhibition of replication in functional mouse adrenal tumor cells by adrenocorticotropin hormone mediated by cAMP". Proc. Nat. Acad. Sci. USA, 68, 3206-3210 (1971).

MASUI, H. \& LA PORTE, P. - "Inhibition of growth of transplanted functional adrenal tumor cells by adrenocorticotropic hormone (ACTH)". Abst. $55^{\text {th }}$ Meeting of the Endocrine Soc. Suppl. Endocrinology, 92, A-54 (1973).

MEZGER-FREED, L. - "Effect of ploidy and mutagens on BUdR resistance in haploid and diploid frog cells". Nature, 235, 245-246 (1972).

MEZGER-FREED, I. - "An analysis of survival in haploid and diploid cell cultures after exposure to ICR acridine half-mustard compounds mutagenic for bacteria". Proc. Nat. Acad. Sci. USA, 71, 4416-4420 (1974).

MIYAMOTO, E.; KUO, J.F. \& GREENGARD, P. - "Cyclic nucleotide dependent protein kinase. III. Purification and properties of adenosine 3',5'-monophosphate-dependent protein kinase from bovine brain". J. Biol. Chem., 244, 6395-6402 (1969). NARDONE, R.M.; TODD, J.; GONZALES, P. \& GAFFNEY, E. "Nucleoside incorporation into strain L cells: inhibition by Pleuropneumonia-like organisms". Science, 149, 1000-1001 (1965). 
NISHIKAWA, K.; ARMELIN, H.A. \& SATO, G. - "Control of ovarian cell growth in culture by serum and pituitary factors". Proc. Nat. Acad. Sci. USA, 72, 483-487 (1975).

NOONAN, K.D. \& BURGER, M. - "Induction of $3 T 3$ cell division at the monolayer stage". Expl. Cell Res., 80, 405-414 (1973).

NOSE, K. \& KATSUTA, H. - "Arrest of cultured rat liver cells in $\mathrm{G} 2$ phase by the treatment with dibutyryl cAMP." Biochem. Biophys. Res. Comm., 64, 983-988 (1975). OLSEN, R. - "Filamentations protein model for cyclic AMP-mediated cell regulatory mechanisms". J. Theor. Biol., 49, 263-287 (1975).

OTTEN, J.; JOHNSON, G.S. \& PASTAN, I. - "Cyclic AMP levels in fibroblasts: relationship to growth rate and contact inhibition of growth". Biochem. Biophys. Res. Comm., 44, 1192-1198 (1971).

OTTEN, J.; JOHNSON, G.S: \& PASTAN, I. - "Regulation of cell growth by cyclic adenosine $3^{\prime}, 5^{\prime}$-monophosphate. Effect of cell density and agents which alter cell growth on cyclic adenosine 3',5'-monophosphate levels in fibroblasts". J. Biol. Chem., 247, 7082-7087 (1972).

PAINTER, P.R. \& MARR, A.G. - "Mathematics of microbial populations". Ann. Rev. Microbiol., 22, 519-548 (1968). PAUL, D.; LIPTON, A. \& KLINGER, I. - "Serum factor requirements of normal and SV40-transformed $3 \mathrm{~T} 3$ mouse fibroblasts". Proc. Nat. Acad. Sci. USA, 68, 645-648 (1971).

PEARLSTEIN, E.S. \& WATERFIELD, M.D. - "Metabolic studies on ${ }^{125}$ I-labeled baby hamster kidney cell plasma membranes". Biochem. Biophys. Acta, 362, 1-12 (1974).

POLLACK, R.E.; GREEN, H. \& TODARO, G.J. - "Growth control in cultured cells: selection of sublines with increased sensitivity to contact inhibition and decresed tumor-producing ability". Proc. Nat. Acad. Sci. USA, 60, 126-133 (1968). 
POLLACK, R.; RISSER, R.; CONLON, S.; FREEDMAN, V.; SHIN, S. \& RIFKIN, D. - "Production of plasminogen activator and colonial growth in semisolid medium are in vitro correlates of tumorigenicity in the immune-deficient nude mouse". In: Proteases and Biological Control; Ed. Reich, E.; Rifkin, D.B. \& Shaw, E. Cold Spring Harbor Laboratory, 885-897 (1975).

PRASAD, K.N. \& SHEPPARD, J.R. - "Neuroblastoma cell culture: membrane changes during cyclic AMP-induced morphological differentiation". Proc. Soc. Exp. Biol. Med., 141, 240-243 (1972).

PUCK, T. - "Studies of the life cycle of mammalian cells". Cold Spring Harbor Symposia, 29, 167-176 (1964).

PUCK, T.T. \& KAO, F.T. - "Genetics of somatic mammalian cells, V. Treatment with 5-bromodeoxyuridine and visible light for isolation of nutritionally deficient mutants". Proc. Nat. Acad. Sci. USA, 58, 1227-1234 (1967).

PUCK, T.T. \& MARCUS, P.I. - "A rapid method for viable cell titration and clone production with Hela cells in tissue culture: the use of X-irradiated cells to supply conditioning factors". Proc. Nat. Acad. Sci. USA, 41, 432-437 (1955).

QUASTLER, H. \& SHERMAN, F.G. - "Cell population kinetics in the intestinal epithelium of the mouse". Exp. Cell Res., $17,420-438$ (1959).

RAMACHANDRAN, J. \& SUYAMA, A.T. - "Inhibition of replication of normal adrenocortical cells in culture by adrenocorticotropin". Proc. Nat. Acad. Sci. USA, 72, 113-117 (1975).

RINDERKNECHT, E. \& HUMBEL, R.E. - "Polypeptides with nonsuppressible insulin-like and cell-growth promoting activities in human serum: isolation, chemical characterization and some biological properties of forms I and II". Proc. Nat. Acad. Sci. USA, 73, 2365-2369 (1976). 
ROBBINS, P.W.; WICKUS, G.G.; BRANTON, P.E.; GAFFNEY, B.J.; HIRSCHBERG, C.B.; FUCHS, P. \& BLUMBERG, P.M. - "The chick fibroblast cell surface after transformation by Rous Sarcoma virus". Cold Spring Harbor Symposia, 39, 1173-1180 (1974).

ROBISON, G.A.; BUTCHER, R.W. \& SUTHERLAND, E.W. - "Cyclic AMP". Academic Press, New York (1971).

ROSCOE, D.H.; ROBINSON, J.J. \& CARBONELI, C. - "DNA synthesis and mitosis in a temperature-sensitive Chinese hamster cell line". J. Cell. Physiol., 82, 333-338 (1973a). ROSCOE, D.H.; READ, M. \& ROBINSON, H.J. - "Isolation of temperature-sensitive mammalian cells by selective detachment". J. Cell. Physiol., 82, 325-332 (1973b). ROSS, R.; GLOMSET, J.; KARIYA, B. \& HARKER, L. - "A platelet-dependent serum factor that stimulates the proliferation of arterial smooth muscle cells in vitro". Proc. Nat. Acad. Sci. USA, 71, 1207-1210 (1974).

RYGAARD, J. - "Thymus and self: Immunobiology of the mouse mutant "nude". F.A.D.L. Copenhagen (1973).

SALMON, W.D. \& DAUGHADAY, W.D. - "A hormonally controlled serum factor which stimulates sulfate incorporation by cartilage in vitro". J. Lab. Clin. Med., 49, 825-836 (1957).

SAMBROOK, J. - "Transformation by polyoma and simian virus 40". Adv. Cancer Res., 16, 141-180 (1972).

SAMUELS, H.; TSAI, J. \& CASANOVA, J. - "Thyroid hormone action: in vitro demonstration of putative receptors in isolated nuclei and soluble nuclear extracts". Science, 184, 1188-1191 (1974).

SATO, G.; AUGUSTI-TOCCO, G.; POSNER, M. \& KELIY, P. "Hormone-secreting and hormone-responsive cell cultures". Recent Progress Horm. Res., 26, 539-546 (1970). 
SATO, G.; ZAROFF, L. \& MILLS, S.E. - "Tissue culture populations and their relation to the tissue of origin". Proc. Nat. Acad. Sci. USA, 46, 963-972 (1960).

SCHIMMER, B.P. - "Phenotypically variant adrenal tumor cell cultures with biochemical lesions in the ACTH-stimulated steroidogenic pathway". J. Cell. Physiol., 74, 115-122 (1969).

SCHIMMER, B.P. - "Adenylate cyclase activity in adrenocorticotropic tumor-sensitive and mutant adrenocortical tumor cell lines". J. Biol. Chem., 247, 3134-3138 (1972).

SCHIMMER, B.P. - "Adenylate ciclase activity and steroidogenesis in phenotypic revertants of an ACTH-insensitive adrenal tumor cell line". Nature, 259, 482-483 (1976).

SCHIMMER, B.P. \& ZIMMERMAN, A.E. - "Steroidogenesis and extracellular CAMP accumulation in adrenal tumor cell cultures": Molec. Cell. Endocrinol., 4, 263-270 (1976). SCHNEBLI, H.P. \& BURGER, M. - "Selective inhibition of growth of transformed cells by protease inhibitors". Proc. Nat. Acad. Sci. USA, 69, 3825-3827 (1972).

SEFTON, B.M. \& RUBIN, H. - "Release from density dependent growth inhibition by proteolytic enzymes". Nature, 227, 843-845 (1970).

SEIFERT, W. \& PAUL, D. - "Levels of cyclic AMP in sparse and dense cultures of growing and quiescent $3 \mathrm{~T} 3$ cells". Nature New Biol., 240, 281-283 (1972).

SEIFERT, W.E. \& RUDLAND, P.S. - "POssible involvement of cyclic GMP in growth control of cultured mouse cells". Nature, 248, 138-140 (1974).

SHARP, J.D.; CAPECCHI, N.E. \& CAPECCHI, M.R. - "Altered enzymes in drug-resistant variants of mammalian tissue culture cells. Proc. Nat. Acad. Sci. USA, 70, 3145-3149 (1973). 
SHEFFLER, I.E. \& BUTTIN, G. - "Conditionally lethal mutations in Chinese hamster cells. I. Isolation of a temperature-sensitive line and its investigation by cell cycle studies". J. Cell. Physiol., 81, 199-216 (1973). SHEPPARD, J.R. - "Difference in the cyclic adenosine 3',5'-monophosphate levels in normal and transformed cells". Nature New Biol., 236, 14-16 (1972).

SHEPPARD, J.R. \& BANNAI, S. - "Cyclic AMP and cell proliferation". In: Control of Proliferation in Animal Cells. Eds. Clarkson, B. \& Baserga, R. Cold Spring Harbor Laboratory, Cold Spring Harbor, New York, 571-579 (1974). SHEPPARD, J.R. \& PRASAD, K.N. - "Cyclic AMP levels and the morphological differentiation of mouse neuroblastoma cells". Life Science II, 12, 431-439 (1973).

SIMMINOVITCH, L. - "On the nature of hereditable variation in cultured somatic cells". Cell, 7, 1-11 (1976). f SMITH, J.A. \& MARTIN, L. - "Do cells cycle?". Proc. Nat. Acad. SCi. USA, 70, 1263-1267 (1973).

SMITH, B.J. \& WIGGLESWORTH, N.M. - "A cell line which is temperature-sensitive for cytokinesis". J. Cell. Physiol., 80, 253-260 (1972).

SMITH, B.J. \& WIGGLESWORTH, N.M. - "A temperature-sensitive function in a Chinese hamster line affecting DNA synthesis". J. Cell. Physiol., 82, 339-348 (1973).

SMIITH, B.J. \& WIGGIESWORTH, N.M. - "Studies on a Chinese hamster line that is temperature sensitive for the commitment to DNA synthesis". J. Cell. Physiol. , 84, 127-134 (1974).

STANLEY, P.; SIMMINOVITCH, L.; NARASIMHIAN, S. \& SCHACTER, H."Chinese hamster ovary cells selected for resistance to the cytotoxicity of phytohemagglutinin are deficient in UDP-N-acetylglucosamine-glycoprotein N-acetylglucosaminyltransferase activity". Proc. Nat. Acad. Sci. USA, 72, 3323-3327 (1975).

STILES, C.D.; DESMOND,.W. Jr.; SATO, G. \& SAIER, M.H. Jr. "Failure of human cells transformed by simian virus 40 to form tumors in athymic nude mice". Proc. Nat. Acad. Sci. USA, 72, 4971-4975 (1975). 
STILES, C.D.; DESMOND, W.; CHUMAN, L.M.; SATO, G. \& SAIER, H. Ir. - "Growth control of heterologous tissue culture cells in the congenitally athymic nude mice". Cancer Research, $36,1353-1360$ (1976).

STOKER, M. - "Abortive transformation by polyoma virus". Nature, 218, 234-238 (1968).

STONE, K.R.; SMITH, R.E. \& JOKLIK, W.K. - "Changes in membrane polypeptides that occur when ahick embryo fibroblasts and NRK cells are transformed with avian sarcoma viruses". Virology, 58, 86=100 (1974).

STUDZINSKI, G.P.; GIERTHY, J.F. \& CHOLON, J.J. - "An autoradiographic screening test for mycoplasmal contamination of mammalian cell cultures". In Vitro, $\mathbf{8}$, $466-472$ (1973).

TASHJIAN, A.; YASUMURA, Y.; LEVINE, L.; SATO, G. \& PARKER, M. - "Establishment of clonal strains of rat pituitary tumor cells that secrete growth hormone". Endocrinology, $\underline{82}, 342-352$ (1968).

TEMIN, H.M. - "Stimulation by serum of multiplication of stationary chicken cells". J. Cell. Phys1ol.; 78, 161-170 (1971).

TENNER, A.; ZIEG, J. \& SHEFFLER, I.E. - "Glycoprotein synthesis in a temperature-sensitive chinese hamster cell cycle mutant". J. Cell. Physiol., 90, 145-160 (1977). THOMPSON, L.; HARKINS, J. \& STANNERS, C. - "A mammalian cell mutant with a temperature-sensitive leucyl-transfer RNA synthetase". Proc. Nat. Acad. Sci. USA, 70, 3094-3098 (1973).

THRASH, C. \& CUNNINGHAM, D. - "Stimulation of division of density inhibited fibroblasts by glucocorticoids". Nature, 242, 399-401 (1973).

THRASH, C.R.; HO, T.S. \& CUNNINGHAM, D.D. - "Structural features of steroids which initiate proliferation of density-inhibited 3 T3 mouse fibroblast's". J. Biol. Chem., 249, 6099-6103 (1974). 
TODARO, G. \& GREEN, H. - "Quantitative studies on the growth of mouse embryo cells in culture and their development into established lines". J. Cell Biol., 17, 299-313 (1963).

TODARO, G. \& GOLDBERG, G. - "Transformation of properties of an established cell line by SV40 and polyoma virus". Proc. Nat. Acad. Sci. USA, 51, 66-73 (1964).

TODARO, G.; LAZAR, G. \& GREEN, H. - "The initiation of cell division in a contact-inhibited mammalian cell line". J. Cell. Comp. Physiol., 66, 325-333 (1965).

TONIOLO, D.; MEISS, H.K. \& BASILICO, C. - "A temperature-sensitive mutation affecting $28 \mathrm{~S}$ ribosomal RNA production in mammalian cells". Proc. Nat. Acad. Sci. USA, 70, 1273-1277 (1973).

UTHNE, K. - "Human somatomedins purification and some studies on their biological actions". Acta Endocrinol. (Copenhagen), Suppl., 175, 1-35 (1973).

VAN WYCK, J.J.; HALI, K.; VAN DER BRANDE, J.L. \& WEAVER, R.P. - "Further purification and characterization of sulfation factor and thymidine factor from acramegalic plasma". J. Clin. Endocrinol.,32,389-396 (1971). VOGEL, A.; OEY, J. \& POLLACK, R. - "TwO classes of revertants isolated from sV40-transformed $3 \mathrm{~T} 3$ mouse cells". In: Control of Proliferation in Animal Cells Ed. Clarkson, B. \& Baserga, R. 125-138 Cold Spring Harbor Laboratory, Cold Spring Harbor, New York (1974).

VOGEL, A. \& POLLACK, R. - "Isolation and characterization of revertant cell lines. IV.Direct selection of serum-revertant sublines of sV40-transformed 3T3 mouse cells". J. Cell. Physiol., 82, 189-198 (1973).

VOGEL, A.; RISSER, R. \& POLLACK, R. - "Isolation and characterization of revertant cell lines. III. Isolation of density-revertants of SV40-transformed 3T3 cells using colchicine". J. Cell. Physiol., 82, 181-189 (1973).

WANG, R.J. - "A temperature-sensitive cell line blocked in mitosis". Nature, 248, 76-78 (1974). 
WIGLER, M.; FORD, J. \& WEINSTEIN, I.B. - "Glucocorticoid inhibition of the fibrinolytic activity of tumor cells". In: Proteases and Biological Control Eds. Reich, E.; Rifkin, D.B. \& Shaw, E. Cold Spring Harbor Laboratory, Cold Spring Harbor, New York, 849-856 (1975).

WILLINGHAM, M.E.; JOHNSON, G.S. \& PASTAN, I. - "Control of DNA synthesis and mitosis in $3 \mathrm{~T} 3$ cells by cyclic AMP". Biochem. Biophys. Res. Comm., 48, 743-748 (1972).

YAMADA, K.M. \& WESTON, J.A. - "Isolation of a major cell surface glycoprotein from fibroblasts". Proc. Nat. Acad. Sci. USA, 71, 3492-3496 (1974).

YASUMURA, Y.; BUONASSISSI, V. \& SATO, G. - "Clonal analysis of differentiated function in animal cell cultures. I. Possible correlated maintenance of differentiated function and the diploid karyotype". Cancer Res., 26, 529-535 (1966). 
Partes do trabalho aqui descrito foram relatadas ou publicadas nas seguintes reuniões ou periōdicos: COMUNICAÇס̃ES :

1. Mari C.S. Armelin e Hugo A. Armelin "Isolamento de clones de fibroblastos $3 \mathrm{~T} 3$ para estudos da regulação do creşcimento celular". Reunião Anual da Sociedade Brasileira de Bioquímica, Caxambu, Minas Gerais (1976).

2. Angelo G. Gambarini, Mari C.S. Armelin, Sonia T. S. Funck e Hugo A. Armelin "Fatores de crescimento para cëlulas de mamiferos em cultura obtidos da hipófise: 1solamento, caracterização e especificldade". Reunião Anual da Sociedade Brasileira de Bioquímica, Caxambu, Minas Gera1s (1976).

3. Mari C.S. Armelin, Angelo G. Gambarini and H.A. Armelin "Extracellular regulators of cell proliferation in mammalian cell cultures". Tenth International Congress of Biochemistry, Hamburgo, Alemanha (1976). Abstracts pg. 522, $11-1-402$.

4. Mari C.S. Armelin and Hugo A. Armelin " $G_{1}$ length studies in $3 \mathrm{~T} 3$ cells: effect of hormones". First International Congress of Cell Biology, Boston, Massachussets, Es tados Unidos (1976) J. Cell Biol. 70, 401a.

5. Mari C.S. Armelin e Hugo A. Armelin "Morfologia e adesão em fibroblastos de camundongo: envolvimento de glicorticöides, cAMP e microtúbulos". Reunião Anual da Socieda de Brastleira de Bioquímica, Caxambu, Minas Gerais (1977). 
6. Mari C.S. Armelin, Sandra E. Farias e Hugo A. Armelin "Regulação hormonal do crescimento e tumorogenicidade do mutante STl derivado de fibroblastos 3T3 de camundongo". Reunião Anual da Sociedade Brasileira de BioquÍmica, Caxambu (1977).

7. Hugo A. Armelin e Mari C.s. Armelin "Ação de hor mônios e fatores sēricos na regulação da síntese de DNA e divisão celular em cēlulas de mamíferos". Reunião Anual da Sociedade Brasileira de Bioquímica, Caxambu, Minas Gerais(1977).

8. Hugo A. Armelin e Mari C.S. Armelin "Isolamento de mutantẹs de células adrenais resistentes a adrenocorticotropina". Reunião da Academia Brasileira de Clências Institun to de QuÍmica, USP, setembro de 1977.

PUBIICAÇర̋ES :

1. Mart C.S. Armelin, Angelo G. Gambarini and Hugo A. Armelin "Protein factors which regulate cell growth". Arch. Biol. Med. Exper. 10, 122-129 (1976).

2. Mari C.S. Armelin and Hugo A. Armelin "Serum and hormonal regulation of the transition between resting and proliferative states in a variant of 3 T3 fibroblasts". Nature $265,148-151$ (1977).

3. Hugo A. Armelin and Mari C.S. Armelin "Resting-proliferative transition in cultured mammalian cells". Nat. Cancer Inst. Monograph. 48 (1977): 
4. Mari C.S. Armelin, Angelo G. Gambarini and Hugo A. Armelin "On the regulation of growth in the $Y-1$ line of mouse adrenal cells: effects of serum and pituitary factors". J. Cell. Physiol. 48 (1977).

5. Mari C.S. Armelin and Hugo A. Armelin "Steroid hormones mediated reversible phenotypic transition between transformed and untransformed state in mouse fibroblasts" Proc. Nat. Acad. Sci. USA (in press).

6. Hugo A. Armelin and Mari C.S. Armelln. "Cell cycle regulation in mammalian cells: hormones and commitment to DNA synthesis". Arch. Biol. Med. Exper. (in press). 